Portland State University

PDXScholar

$1-1-2010$

\title{
Initiation zone characterization of debris flows in November, 2006, Mount Hood, Oregon
}

Rachel Pirot

Portland State University

Follow this and additional works at: https://pdxscholar.library.pdx.edu/open_access_etds Let us know how access to this document benefits you.

\section{Recommended Citation}

Pirot, Rachel, "Initiation zone characterization of debris flows in November, 2006, Mount Hood, Oregon" (2010). Dissertations and Theses. Paper 707.

https://doi.org/10.15760/etd.707

This Thesis is brought to you for free and open access. It has been accepted for inclusion in Dissertations and Theses by an authorized administrator of PDXScholar. Please contact us if we can make this document more accessible: pdxscholar@pdx.edu. 
Initiation Zone Characterization of Debris Flows

in November, 2006, Mount Hood, Oregon

by

Rachel Pirot

A thesis submitted in partial fulfillment of the requirements for the degree of

Master of Science

in Geology

Thesis Committee:

Scott F. Burns, Chair

R. Benjamin Perkins

Richard M. Iverson

Thomas C. Pierson

Portland State University

(C) 2010 


\begin{abstract}
In November, 2006, a storm generated a minimum of $34 \mathrm{~cm}$ of precipitation in six days, triggering debris flows in many of the drainages on all sides of Mount Hood, Oregon. Of the eleven drainages surveyed, seven experienced debris flows; these include the White River, Salmon River, Clark Creek, Newton Creek, Eliot Creek, Ladd Creek and Sandy River basins. Flows in the White River, Eliot Creek, and Newton Creek, caused major damage to bridges and roadways. Initiation elevations averaged around 1,860 meters. Initiation zone material was predominantly sand $(45-82 \%)$ with gravel (15-49\%) and had few fines (3-5\%). Four debris flows were triggered by landslides caused by undercutting of the river banks. Three developed through coalescence of multiple small debris flows within major channels and were termed "headless debris flows". Physical and morphological characterization of source areas was used to assess factors controlling debris flow initiation. Although findings indicate that all major drainages on Mount Hood are capable of producing debris flows, drainages with direct connection to a glacier, low percentages of vegetation, and moderate gradients in the upper basin were the most susceptible. Among basins not having debris flows, neither the Zigzag River nor Polallie Creek have a direct connection to a glacier, And the Muddy Fork and the Coe both have high percentages of vegetated slopes. The material in the upper basin of the Muddy Fork is predominately rock making initiation there weathering-limited. Additionally, the
\end{abstract}


Muddy Fork and the Zigzag have two of the steepest gradients on the mountain. This pattern suggests that material there is regularly transported downstream through normal fluvial processes rather than building up to be catastrophically removed through debris flow processes. 


\title{
Acknowledgments
}

I would like to acknowledge my husband, Branden Pirot. Without your support and encouragement I would not have been able to do any of this.

I would also like to thank my advisor, Scott Burns, for your support and enthusiasm, and my field assistants, Adam Jones and Tom Bennett for accompanying me during my two summers of field work. I appreciate your willingness to follow my lead, even when I was still just trying to figure things out. I have great appreciation for my committee members (Dick Iverson, Tom Pierson, and Ben Perkins) for your time and assistance in executing and finally finishing this project. I would like to give special recognition to Tom DeRoo of the Mt Hood National Forest. I found your advice, experience, assistance and friendship to be invaluable; thank you.

I would like to thank the organizations that awarded me with scholarships and grants which enabled me to dedicate two summers to complete this project:

\author{
Grant in aid of Research, Sigma Xi \\ Shlemon Scholarship, Geological Society of America
}

Student Research Grant, Mazamas

Stout Scholarship, Association of Environmental and Engineering Geologists 


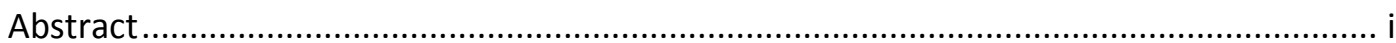

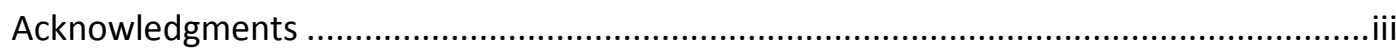

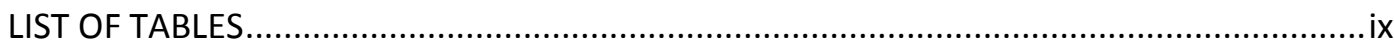

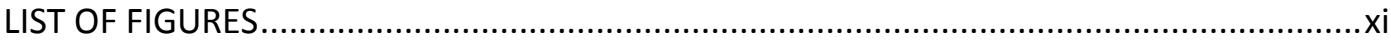

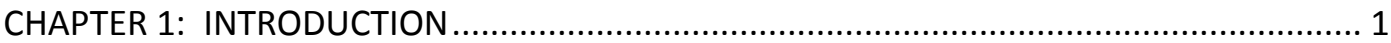

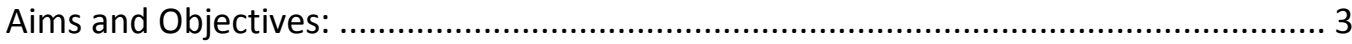

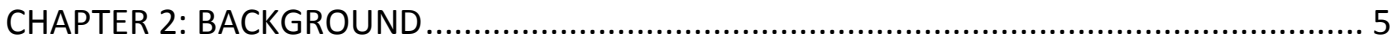

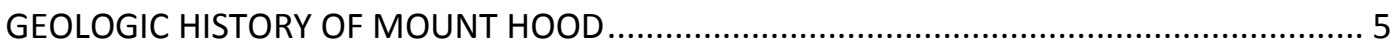

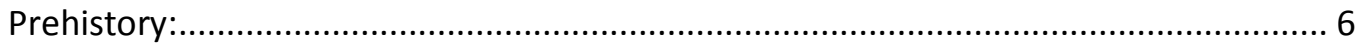

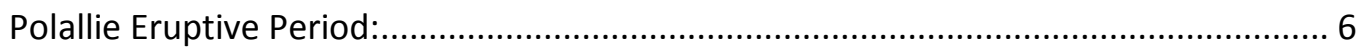

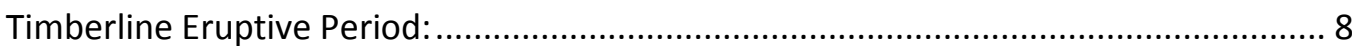

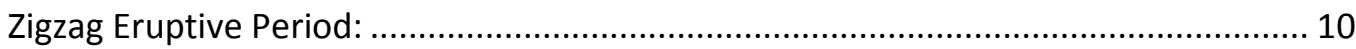

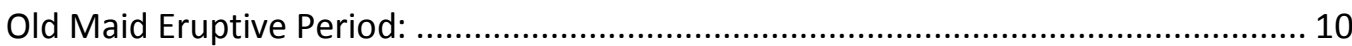

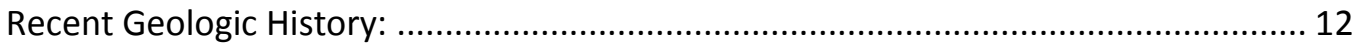

Summary:

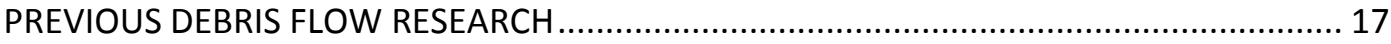

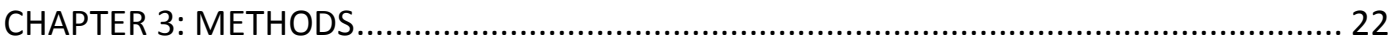

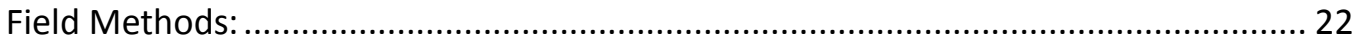


Initial Reconnaissance:

Detailed Mapping of the Initiation Zone: ................................................... 26

Sample Collection ............................................................................ 27

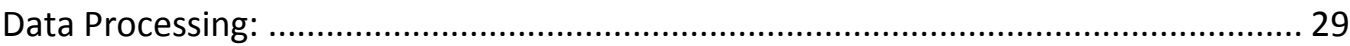

Laboratory Sieve Analysis: .................................................................... 29

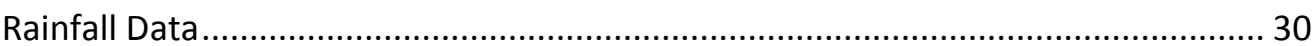

Drainage Basin Attributes: ................................................................. 32

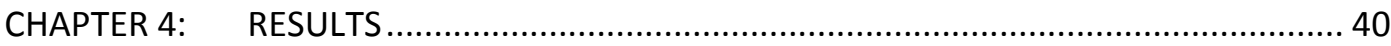

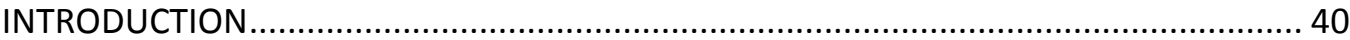

ELIOT CREEK DRAINAGE BASIN: ........................................................ 41

Reconnaissance \& Sample Collection: ................................................... 41

Data Processing:.............................................................................. 47

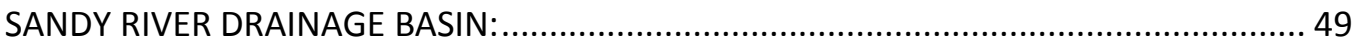

Reconnaissance \& Sample Collection: ......................................................... 50

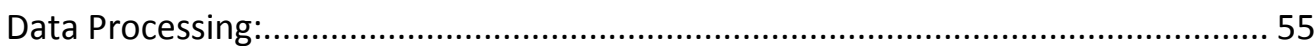

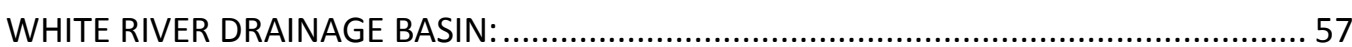

Reconnaissance \& Sample Collection: ...................................................... 58

Data Processing:.............................................................................. 61

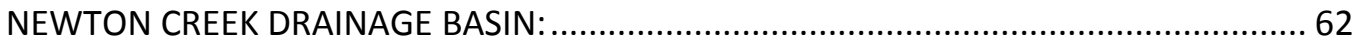


Reconnaissance \& Sample Collection:

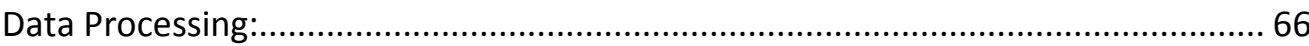

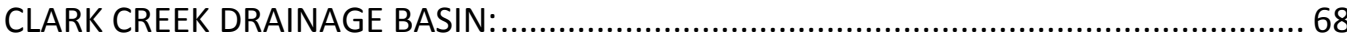

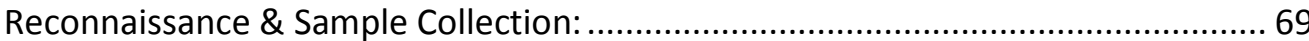

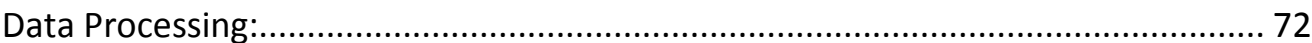

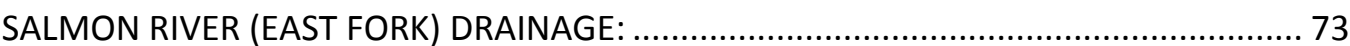

Reconnaissance \& Sample Collection: ...................................................................... 73

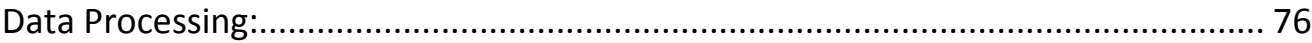

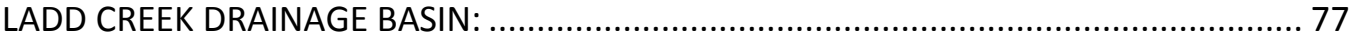

Reconnaissance \& Sample Collection: ................................................................. 78

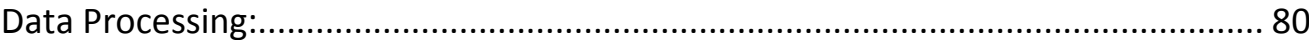

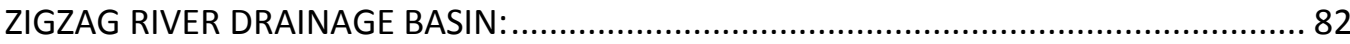

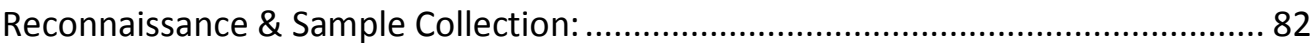

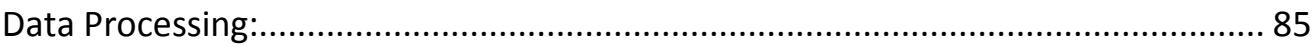

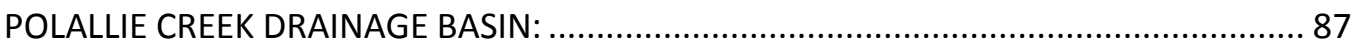

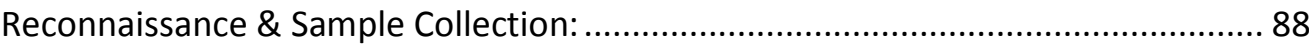

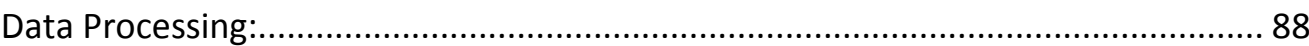

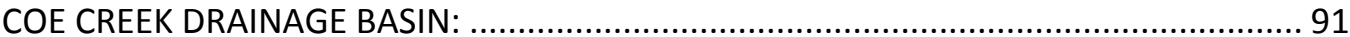

Reconnaissance \& Sample Collection: .............................................................. 91 
Data Processing:

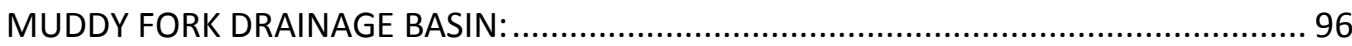

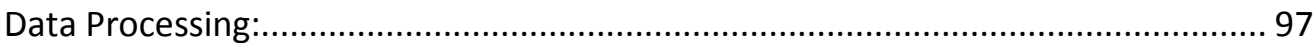

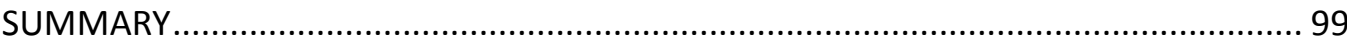

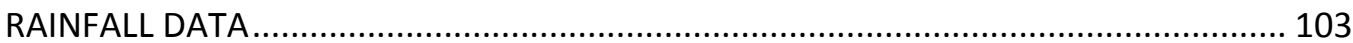

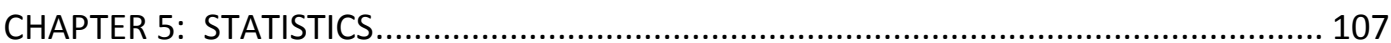

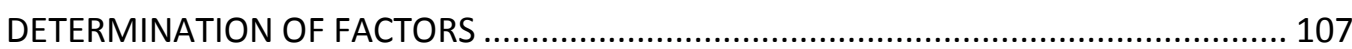

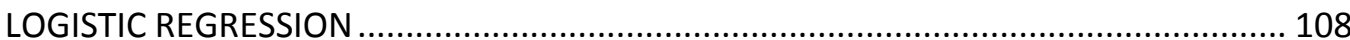

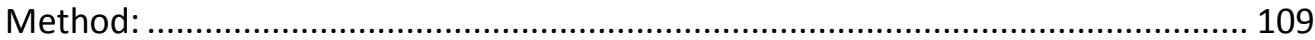

Limitations, Input Requirements, \& Assumptions:.............................................. 115

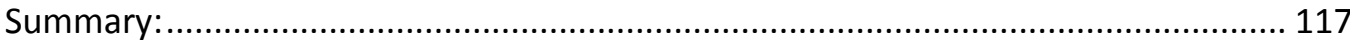

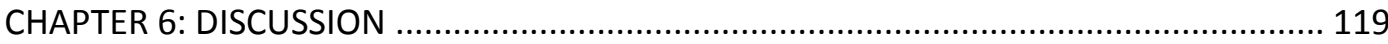

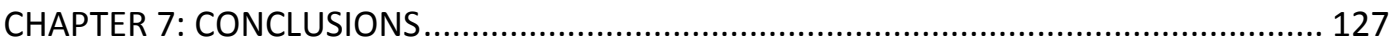

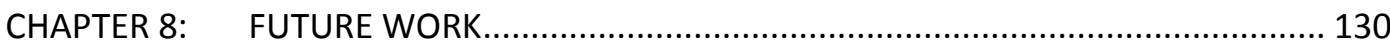

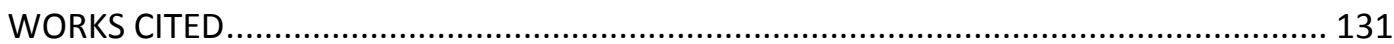

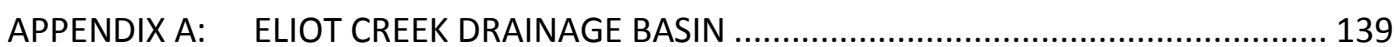

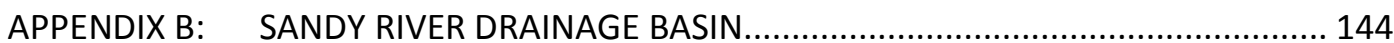

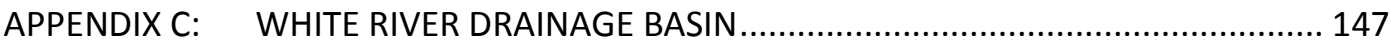

APPENDIX D: $\quad$ NEWTON CREEK DRAINAGE BASIN ................................................. 152 


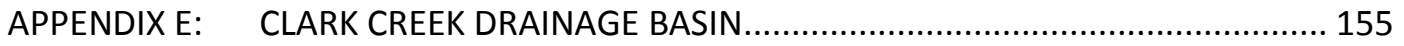

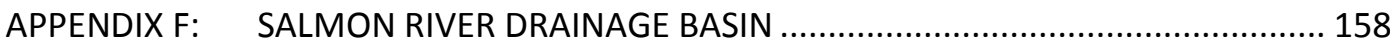

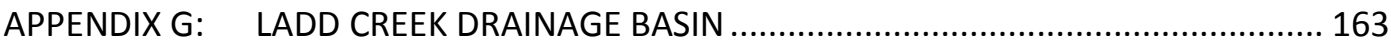

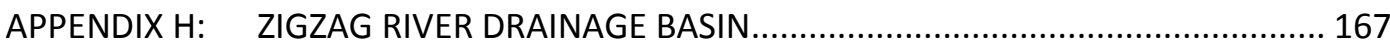

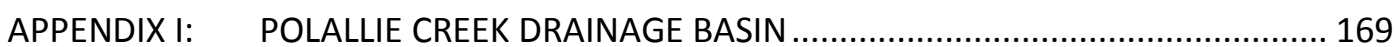

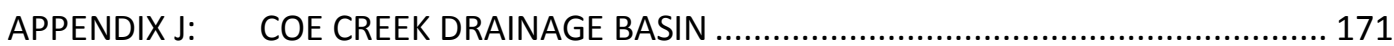

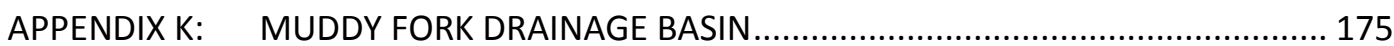

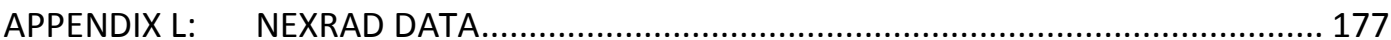

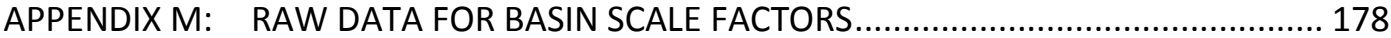

APPENDIX N: $\quad$ NORMALIZED DATA FOR BASIN SCALE FACTORS ................................. 179 
Table 1. Recent debris flows on Mount Hood ................................................... 14

Table 2. Eliot Creek sieve results ..................................................................... 48

Table 3. Sandy River Sieve Results ..............................................................56

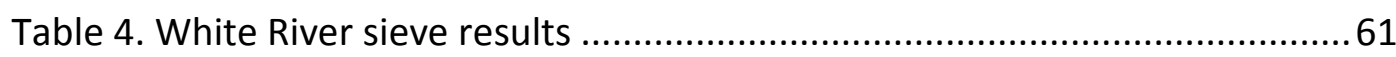

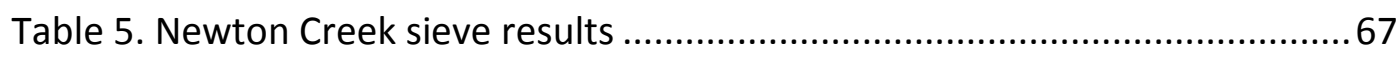

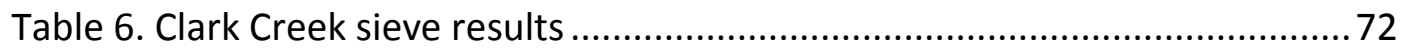

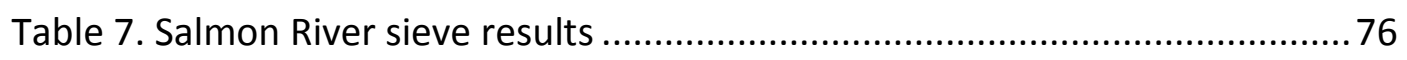

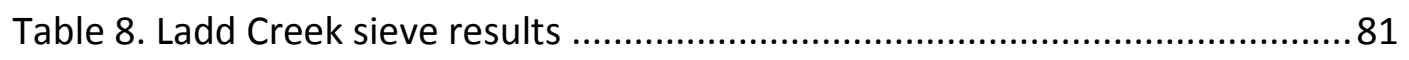

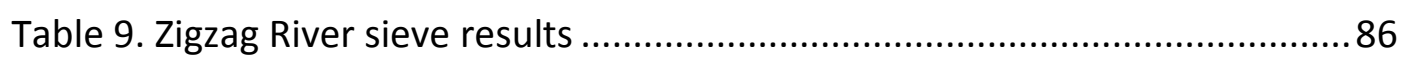

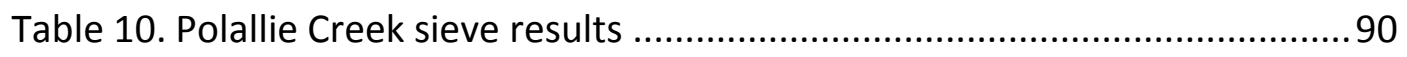

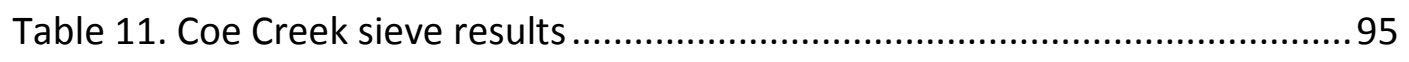

Table 12. Muddy Fork sieve results ................................................................. 98

Table 13. Initiation zone parent material by drainage ........................................ 100

Table 14. Summary chart of drainage basin characteristics ................................ 101

Table 15. SNOWTEL daily precipitation data for November 3-8 …......................104

Table 16 - Variables Measured for all Basins .......................................................109

Table 17 - Outputs and ANOVA for Regression 0 ………………………….......111

Table 18 - Results from first five regressions showing Wald results for coefficients 
Table 19 - Output and ANOVA for Regression 5 ...........................................113

Table 20 - Sample of results from logistic regression .................................... 115 
Figure 1. Mount Hood and vicinity 2

Figure 2. Geologic map of Mount Hood (Sherrod \& Scott, 1995) .................................. 7

Figure 3. 2006 debris flow drainages are in red; drainages in blue did not have debris

flows. 15

Figure 4. Existing flow nomenclature fitted into rheologic classification (Pierson \& Costa, 1987) 19

Figure 5. Headless debris flow trails in Newton Creek Drainage 28

Figure 6. Sample collection hole from the White River Drainage (UTM 0602484N, $5019919 E)$ 29

Figure 7. Eliot Creek shown in dashed black 40

Figure 8. Laurance Lake Road at Eliot Creek crossing 42

Figure 9. Mud coating on tree near Laurance Lake Road............................................ 42

Figure 10. Log jams and trees stripped of bark just south of Laurance Lake Road........... 43

Figure 11. Abandoned channel in the fan next to Eliot Creek near Laurance Lake Road. 43

Figure 12. Damaged water intake structure for Hood River Irrigation District on Eliot

Creek. 44

Figure 13. Eliot Creek landslide $\left(\sim 273,000 \mathrm{~m}^{3}\right)$ in west lateral moraine (UTM $0604827 \mathrm{~N}$, 5028150 E) 46

Figure 14. Eliot Creek landslide $\left(\sim 230,000 \mathrm{~m}^{3}\right)$ in east lateral moraine (UTM 0604976N, $5028133 E)$ 46 
Figure 15. Eliot Creek sample collection site marked by red star (UTM 0604937N, $5028012 \mathrm{E})$

Figure 16. Sandy River shown in dashed black

Figure 17. Sandy River log jam upstream from Timberline Trail crossing (looking east) .. 51

Figure 18. Sandy River splintered tree stumps near Timberline Trail crossing ..... 51

Figure 19. Sandy River debris flow deposit overlying vegetation of previous ground

surface 52

Figure 20. Landslide along steep canyon wall upstream from the Timberline Trail.......... 52

Figure 21. Sandy River initiation zone $\left(\sim 271,000 \mathrm{~m}^{3}\right)$ (UTM 0598770N, 5024282E) ......... 53

Figure 22. Sandy River debris trail downstream from initiation zone .............................54

Figure 23. Sandy River sample collection site (UTM 0599149N, 5024071E) ..................... 55

Figure 24. White River is shown in dashed black ..................................................... 57

Figure 25. White River Bridge covered by debris flow deposit (ODOT photo) ................... 58

Figure 26. Fine grained layers in debris flow levees upstream from the Timberline Trail 60 Figure 27. White River sample collection site (UTM 0602484N, 5019919E)..................... 60

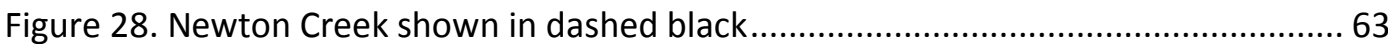

Figure 29. Newton Creek at Highway 35 crossing ........................................................... 65

Figure 30. Highway 35 damage east of Hood River Bridge (photo courtesy of ODOT) ..... 65

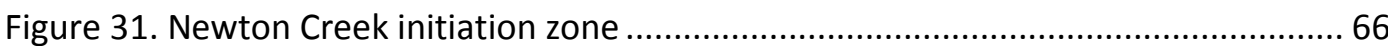

Figure 32. Newton Creek sample collection location (UTM 0605698N, 5023493E) ......... 67

Figure 33. Clark Creek shown in dashed black (Show trail crossings on map) ...................69

Figure 34. Clark Creek initiation zone $\left(\sim 4,860 \mathrm{~m}^{3}\right)$ (UTM 0604875N, 5022881E) ............ 71

Figure 35. Clark Creek sample collection site (UTM 0605216N, 5022626E) ...................... 71 
Figure 36. Salmon River shown in dashed black

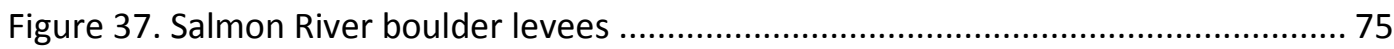

Figure 38 Salmon River sample collection site (UTM 0601358N, 5021270E) .................... 75

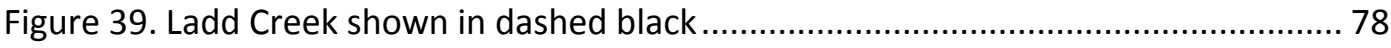

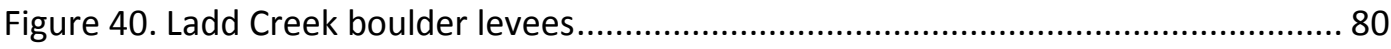

Figure 41. Ladd Creek initiation zone $\left(\sim 3,060 \mathrm{~m}^{3}\right)$ \& sample collection site (UTM

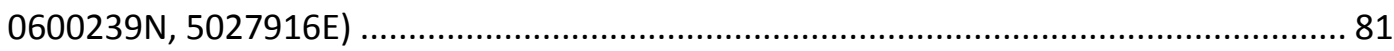

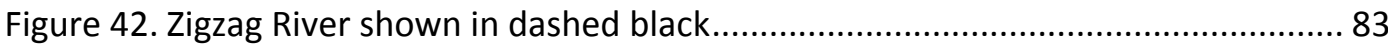

Figure 43. Zigzag River vegetation along active stream margin and canyon walls ........... 84

Figure 44. Zigzag River sample collection site (UTM 0598822N,5022666E) .................... 85

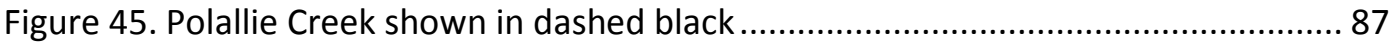

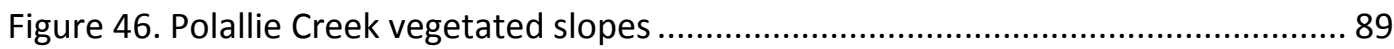

Figure 47. Polallie Creek sample collection site (UTM 0605298N, 5027373E) ................. 90

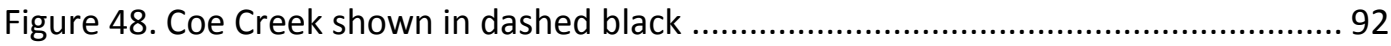

Figure 49. Coe Creek above Laurance Lake Road......................................................... 93

Figure 50. Coe Creek sample collection site (UTM 0602544N, 5028643E) ...................... 94

Figure 51. Muddy Fork of the Sandy River shown in dashed black ............................... 97

Figure 52. Muddy Fork sample collection site (UTM 0598762N, 5027046E) ................... 98

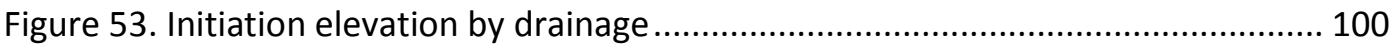

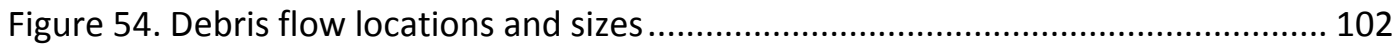

Figure 55. SNOWTEL sites near Mount Hood

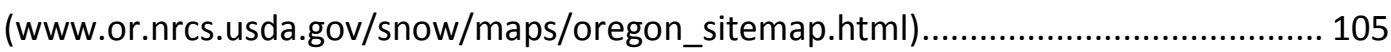


Figure 56. Close-up of NEXRAD Storm data showing total rainfall in $\mathrm{cm}$ (written communication, Todd Parker, USFS 2008)

103 


\section{CHAPTER 1: INTRODUCTION}

Mount Hood is a subduction-related andesitic composite volcano located in the Cascade Range in northern Oregon. It is located 70 kilometers to the east of Portland and is the highest peak in Oregon at about 3,430 meters high (Cameron \& Pringle, 1987). The mountain is home to 12 glaciers and named snow fields. There are 11 major river drainages that come off the peak, and they come together to form 3 primary river systems leaving the mountain (Figure 1). These three major river systems are the White River which drains to the southeast into the Deschutes River, the Hood River which drains to the north into the Columbia River, and the Sandy River which drains to the west, also into the Columbia.

In November, 2006, a large storm swept into the Pacific Northwest region. The storm brought warm, moist air from the central Pacific Ocean and was colloquially known as a Pineapple Express. This storm came before the first snow of the season in the mountains. The storm affected not only Mount Hood but also other volcanoes in the region including Mount Jefferson, Mount St. Helens, Mount Rainier, and Mount Adams (Copeland et al., 2008; Sobieszczyk et al., 2009; Burns et al., 2009), and caused widespread damage due to flooding and debris flows.

Storm-related damages on Mount Hood included damage to four bridges around the mountain. The White River Bridge, on Highway 35, was completely buried by debris and sustained damage to guardrails and adjacent sections or roadways. Two 
bridges spanning the Eliot Creek were ripped from their foundations and carried downstream, and one bridge crossing the Sandy River had its abutment ripped away making it impassable.

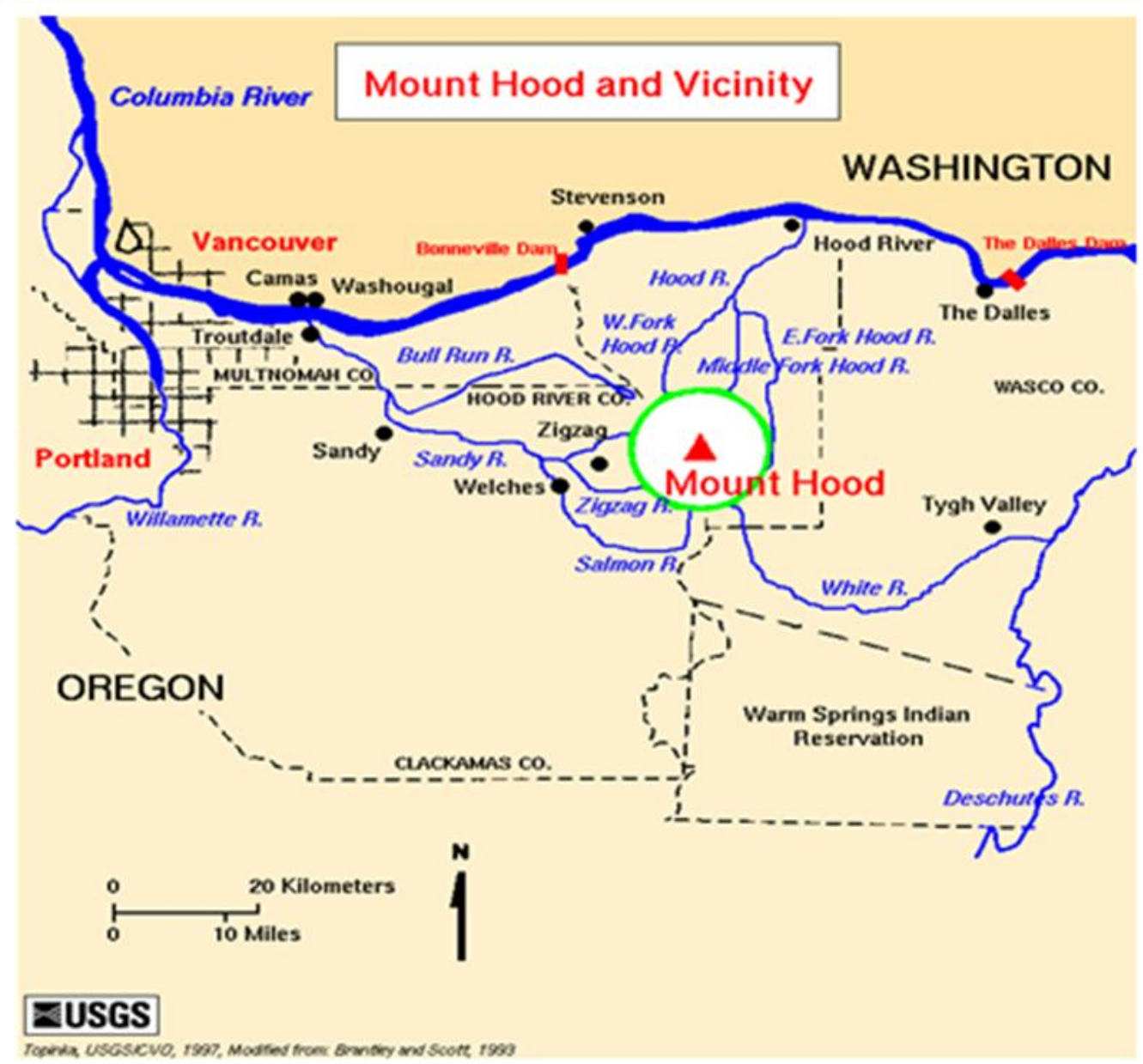

Figure 1. Mount Hood and vicinity

In addition to the damage to bridges, Highway 35 was torn apart in two places by debris flows, and numerous trail bridges were damaged or destroyed around the mountain. A new delta formed into the Columbia River at the mouth of the Hood River, with an emergent area of approximately $0.1 \mathrm{~km}^{2}$, as measured in Google Earth, 
due to sedimentation from the single storm. The Hood River Irrigation District intake structure on the Eliot Creek was also completely destroyed. After the storm, it immediately began to snow. The mountain was quickly blanketed in snowpack for the winter, and evidence of debris flows was effectively buried until the following summer. It was known where debris flows had impacted roads; however, the true extent of debris flow activity around the mountain was still unknown.

Debris flows that had impacted infrastructure were located on all sides of the mountain. This distribution seemed to indicate that the impact of the storm was not predominantly directional. However, not all drainages had the same response to the storm. Some drainages that did not appear to have experienced debris flows at all were nestled between drainages that did. A better understanding of why some drainages responded with debris flows while others didn't could provide useful information for future hazard mapping and identification.

\section{Aims and Objectives:}

The main objectives of this project were to answer the following questions: which drainages around the mountain experienced debris flows as a result of the November 2006 storm, why did some drainages respond to the storm conditions with debris flows and others did not, and finally, what are the primary factors controlling debris flow initiation in the upper drainage basins? In order to answer these questions I combined information collected from a ground-based reconnaissance with a 
sampling program and remote sensing techniques to identify where debris flows occurred and characterize the primary factors controlling debris flow initiation for comparison between every major drainage around the mountain. 


\section{CHAPTER 2: BACKGROUND}

\section{GEOLOGIC HISTORY OF MOUNT HOOD}

Mount Hood has erupted repeatedly for hundreds of thousands of years. However, historical observations are scarce and so most of our information about Mount Hood's behavior in the past comes from the geologic study of prehistoric volcanic deposits (Scott et al., 1997). This active volcano is situated near growing communities and recreation areas. It is estimated to be more then 500,000 years old (Gardner et al., 2000) and has been heavily affected by glaciations. The modern cone is thought to have been sculpted by ice during the Fraser glaciation, 10,000 to 29,000 years ago (Cameron and Pringle, 1987). Present day topography of Mount Hood has also been shaped by Quaternary debris avalanches which occurred about 100,000 years ago (Gardner et al., 2000) and during eruptive periods. These eruptive periods include the Polallie, thought to have occurred between 15,000 12,000 years ago (Crandell, 1980), Timberline, dated at 1,400 to 1,800 years before present (Crandell, 1980; Cameron and Pringle, 1986), Zigzag, which occurred 400 to 600 years before present (Cameron and Pringle, 1986), and the Old Maid eruptive period dated at 170 to 220 years before present (Cameron and Pringle, 1987). Understanding of Mount Hood's history is important for future hazard management and planning purposes. 


\section{Prehistory:}

Prehistoric information about Mount Hood is scarce. However, the oldest rocks found on Mount Hood are from the basaltic to andesitic Sandy Glacier volcano which underlies the west flank of Mount Hood. Lava flows with ages around 900,000 years crop out in the Muddy Fork of the Sandy River (Scott et al., 1997). It is also known that approximately 100,000 years ago a large portion of the volcano's north flank and summit collapsed, due to increased eruptive activity, resulting in a massive debris avalanche which quickly transformed into a catastrophic lahar. This torrent swept down the Hood River Valley and is estimated to have been 122 meters thick at the junction of Hood River and the Columbia. The massive lahar surged across the Columbia River and swept up the White Salmon River Valley on the Washington side. Subsequent lava eruptions then filled in the scar left on the north flank by the debris avalanche (Gardner et al., 2000). Unlike Mount St. Helens to the north, eruptions on Mount Hood did not routinely produce large ash and tephra deposits. Rather, they normally expelled lava flows and domes which often led to the melting of glacier ice and the production of lahars.

\section{Polallie Eruptive Period:}

The Polallie eruptive period occurred approximately 15-12 thousand years ago during the final stage of the Fraser Glaciation (Crandell, 1980). Lahars, thin tephras, and pyroclastic flows from this period are interbedded with late Fraser-age outwash in the Upper Hood River Valley. As evidence that the Polallie eruptive period did 
occur concurrently with the Fraser glaciation, Polallie deposits mantle ridge crests and valley walls but not valley floors. It is thought that glacial ice most likely still occupied valley floors at the time of the eruptions (Swanson et al., 1989). After the Polallie eruptive period, the volcano underwent an apparent time of quiescence, with no evidence for major eruptive behavior occurring until the Timberline eruptive period (Swanson et al., 1989).

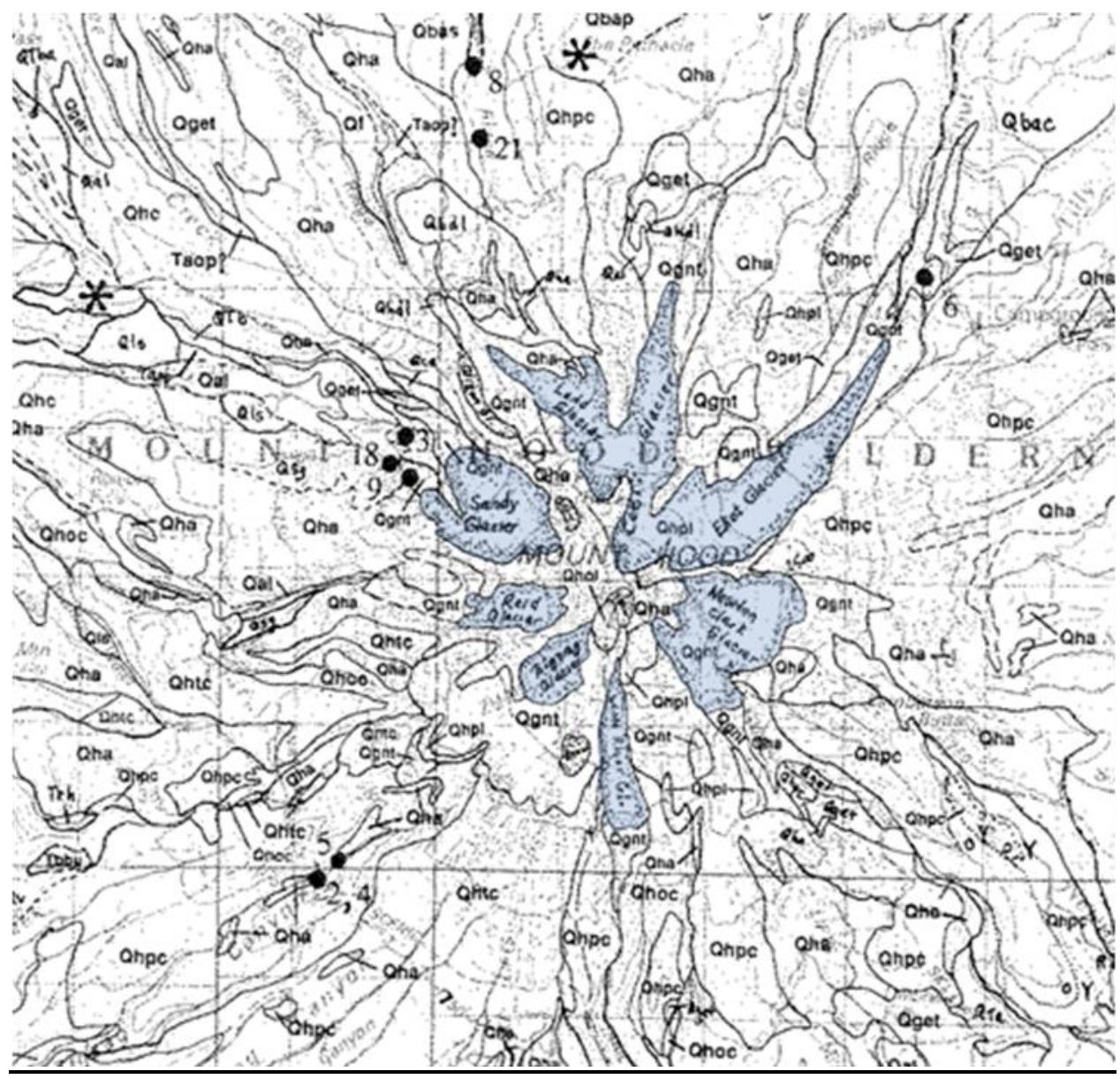

Figure 2. Geologic map of Mount Hood (Sherrod \& Scott, 1995) 
Products of the Polallie eruptive period include lava flows and fragmental deposits from vents on the upper flanks. The deposits are chiefly found on the south and east flanks. The lava consists of andesite and dacite flows and domes that extend as far as $3 \mathrm{~km}$ from Mount Hood's summit (Sherrod and Scott, 1995). Lavas of the Polallie eruptive period are denoted as hpl in Figure 2. Pyroclastic-flow and debrisflow deposits consist of poorly sorted boulders, cobbles and pebbles in a predominantly gray sandy matrix. Minor debris avalanche deposits of hydrothermally altered material are also included (Sherrod and Scott, 1995). Clastic deposits of the Polallie eruptive period are denoted as hpc in Figure 2. These materials appear to have erupted episodically over a time period of at least several thousand years during the Frasier Glaciation (Crandell, 1980). Adjacent to Newton Creek, three sequentially younger deposits are identified with the youngest lining the valley floor. This youngest deposit shows no evidence of hot emplacement temperatures and so is inferred to have formed from the reworking of older Polallie deposits. The oldest deposits are preserved on ridge tops and were probably emplaced near the time of the maximum extent of glaciers during the Evans Creek advance of the Fraser Glaciation approximately 20,000 years ago (Sherrod and Scott, 1995).

\section{Timberline Eruptive Period:}

"The Timberline eruptive period broke the apparent 10-thousand-year-long post-Polallie quiescence. The vent shifted from its summit location during Polallie 
time to the high southwest flank" (Swanson et al., 1989). This event is dated at 1,400 to 1,800 years before present. Erupted material was predominantly confined to the Sandy, Salmon, and Zigzag River drainages. There, it mantled the broad, gently sloping debris fan that dominates the southwest flank of the volcano (Swanson et al., 1989). Lahars of Timberline age are the most voluminous of the post-glacial lahar sequences and reached the mouth of the Sandy River more than 80 kilometers from the volcano (Cameron and Pringle, 1986; Swanson et al., 1989; Rapp, 2005). Pyroclastic flows from this period have been dated at 1,440+/- 155 years B.P. (Cameron and Pringle, 1986) and moved at least 8 kilometers down the Zigzag River (Swanson et al., 1989). A debris avalanche is also known to have occurred at this time from the upper south flank of the mountain. The scar from this event is still visible as it forms the amphitheater around Crater Rock. The subsequent lahar traveled the length of the Sandy River Valley depositing boulders as large as 2.4 meters in diameter, 9.1 meters above the present river level (Gardner et al., 2000).

Products of the Timberline eruptive period form thick fill on the southwest and west flanks of Mount Hood. They include pyroclastic-flow and debris-flow deposits consisting of poorly sorted pebbles, cobbles, and boulders in a predominantly sandy reddish gray matrix (Sherrod and Scott, 1995; Rapp, 2005). Pyroclastic flow deposits extend down the Zigzag River from the vent for a distance of $12 \mathrm{~km}$. In the 
Sandy River drainage, debris flow deposits extend all the way to the Columbia River (Sherrod and Scott, 1995). These units are identified as htc in Figure 2. Another debris avalanche is also included as a product of the Timberline period. It is located in Ladd Creek and consists of poorly sorted boulders to pebbles from white to reddish brown hydrothermally altered lava in a matrix of combined sand, silt, and clay clasts which are predominantly subangular in nature (Sherrod and Scott, 1995). This unit is depicted as htd in Figure 2.

\section{Zigzag Eruptive Period:}

The Zigzag eruptive period was apparently minor. Deposits from several lahars and related floods form an 8 meter high terrace along a reach of the Zigzag River below its confluence with the Little Zigzag River. One pyroclastic flow deposit from this period is found along the Sandy River. The pyroclastic flow has an age of 455 +/- 130 years old (Cameron and Pringle, 1986).

\section{Old Maid Eruptive Period:}

The Old Maid eruptive period apparently began with emplacement of the Crater Rock hornblende dacite dome high on the south flank of the cone (Cameron and Pringle, 1986). It is suspected that numerous lahars were fed by avalanches from the dome building and subsequent snowmelt. These lahars entered the Sandy, Zigzag, Salmon, and White Rivers. Many of them show long run out lengths from the mountain. One of the lahar deposits extends 65 kilometers along the White 
River. In the upper White River, near Timberline Lodge, lahar and fluvial deposits partly fill the canyon. Dendrochronology used for dating these events (Cameron and Pringle, 1987) indicates that lahars and pyroclastic flows of this period occurred between 170-220 years before present" (Swanson et al., 1989). Deposits in the Sandy River and Zigzag River flats of this age are evident due to a distinct change in vegetation. This zone is covered by stunted pine trees and also characterized by a lack of undergrowth. This "dry" vegetation zone, found in Old Maid Flats on the west side of $\mathrm{Mt}$. Hood, is the result of the lack of soil formation due to the relative youth of the deposits (Cameron and Pringle, 1986). The sandy lahar deposits drain quickly and make it difficult for vegetation to survive. The Old Maid eruptive period documents the most recent volcanic activity on Mount Hood.

Products of the Old Maid eruptive period include rock avalanche deposits of hydrothermally altered material from the upper flanks of Mount Hood and pyroclastic deposits formed during eruptions. These eruptions were dominated by extrusion of lava domes and then subsequent collapse of such domes due to explosive disruption or gravity related collapse (Sherrod and Scott, 1995). Valleys on the south and west flanks of the mountain accumulated thick sequences of volcaniclastic debris. Lava of this period includes the dacite dome which forms Crater Rock near the summit of Mount Hood (Sherrod and Scott, 1995). This lava is denoted as hol in Figure 2. Pyroclastic and debris-flow deposits of this period 
are primarily composed of poorly sorted dacite boulders, cobbles, and pebbles supported by a sandy gray matrix with interbeds of silt and sand. These deposits comprise the thick fill which currently resides in the upper White River and Sandy River valleys. Pyroclastic-flow deposits are found as much as $8 \mathrm{~km}$ from the vent (Sherrod and Scott, 1995). They are denoted as hoc in Figure 2.

\section{Recent Geologic History:}

Since the Old Maid eruptive period, Mount Hood has continued to exhibit signs of activity including earthquakes and steam as well as non-volcanic specific processes involving debris flows, floods, and debris avalanches. In 1907 dense steaming was observed around Crater Rock accompanied by a nighttime glow. Throughout this century such minor fumarolic activity has continued mostly centered near Crater Rock (Scott et al., 1997). Earthquakes also occur sporadically on Mount Hood, typically small swarms of low-magnitude (< magnitude 3.5 ) events. They are predominantly located on the south flank below the summit at shallow depths (less than $11 \mathrm{~km}$ ). Swarms of these small quakes occurred in summer 1980 as well as in February 1990 (Scott et al., 1997). In this century however, probably the most notable activity on Mount Hood is the prevalence of large debris flows.

Usually, accounts of these debris flow events surface when the flow is large enough to impact highway infrastructure near the mountain. Such was the case for the Polallie Creek debris flow which not only impacted the highway, but caused loss 
of life as well. On December 25, 1980, an intense rainstorm triggered a landslide at the head of Polallie Creek Canyon on the northeast flank of Mount Hood. The landslide transformed rapidly into a debris flow which burst out of Polallie Creek Canyon killing the lone camper at the campground located at the confluence of Polallie Creek and East Fork Hood River (Gallino and Pierson, 1985).

The White River Valley is probably the most active area on the volcano for debris flow activity presently. The steep slopes of loose deposits in the upper valley act as rich sources of sediment for debris flows (DeRoo, 2009). On September 3, 1998, several debris flow surges originated near the snout of the White River Glacier. These surges deposited material over the width of the valley bottom, raising the elevation there by .3 to 4.5 meters. Since 1907 the White River Bridge has been washed out 20 times as a result of debris flows and floods (Anderson et al., 2006). Other, more remote drainages such as the Muddy Fork of the Sandy River have also produced large events in recent years. On June 14, 2002, a rock failure of 34,500 cubic meters occurred in the upper reaches of the Muddy Fork. This failure initiated as a rock fall but swiftly progressed into a rock/debris avalanche upon impact. This avalanche then transformed into a large debris flow and finally a hyper-concentrated flow farther down channel (Clark and Burns, 2005). 
Since 1907 other drainages around the mountain have experienced documented debris flows as follows: Coe Creek (2), Ladd Creek (2), Newton Creek (7), Polallie Creek (2), Clark Creek (3), Eliot Creek (3), Sandy River (3), and the Muddy Fork (2) (DeRoo, 2009). These events are listed in Table 1.

Table 1. Recent debris flows on Mount Hood

\begin{tabular}{|c|c|c|c|}
\hline Drainage & Year & Month & $\begin{array}{c}\text { Initiation } \\
\text { Elevation }(\mathrm{m})\end{array}$ \\
\hline Coe & 1958 & November & unknown \\
\hline Ladd & 1961 & September & 2100 \\
\hline Newton & 1978 & August & unknown \\
\hline Polallie & 1980 & December & 2000 \\
\hline Newton & 1991 & November & unknown \\
\hline Newton & 1995 & unknown & unknown \\
\hline Ladd & 1996 & unknown & unknown \\
\hline Polallie & 1997 & October & 1900 \\
\hline Clark & 1997 & unknown & unknown \\
\hline Newton & 1998 & July & 2000 \\
\hline Clark & 1999 & November & 2300 \\
\hline Eliot & 1999 & November & 1900 \\
\hline Coe & 2000 & October & 1800 \\
\hline Newton & 2000 & October & 2200 \\
\hline Clark & 2000 & October & 2400 \\
\hline Eliot & 2000 & January & 1900 \\
\hline Eliot & 2000 & October & 1900 \\
\hline Sandy & 2000 & October & 2100 \\
\hline Muddy Fork & 2000 & October & 1800 \\
\hline Muddy Fork & 2002 & June & 1700 \\
\hline Newton & 2003 & October & 2100 \\
\hline Clark & 2003 & October & 2300 \\
\hline Sandy & 2003 & October & unknown \\
\hline Clark & 2005 & September & unknown \\
\hline Sandy & 2005 & September & unknown \\
\hline Newton & 2005 & September & 2300 \\
\hline
\end{tabular}


The most recent notable debris flows on Mount Hood occurred in November, 2006. A regional storm triggered debris flows on all sides of the volcano. Of the eleven main drainages, seven experienced powerful debris flows; these include the White River, Salmon River, Clark Creek, Newton Creek, Eliot Creek, Ladd Creek and Sandy River basins. The location of the river valleys which produced debris flows in

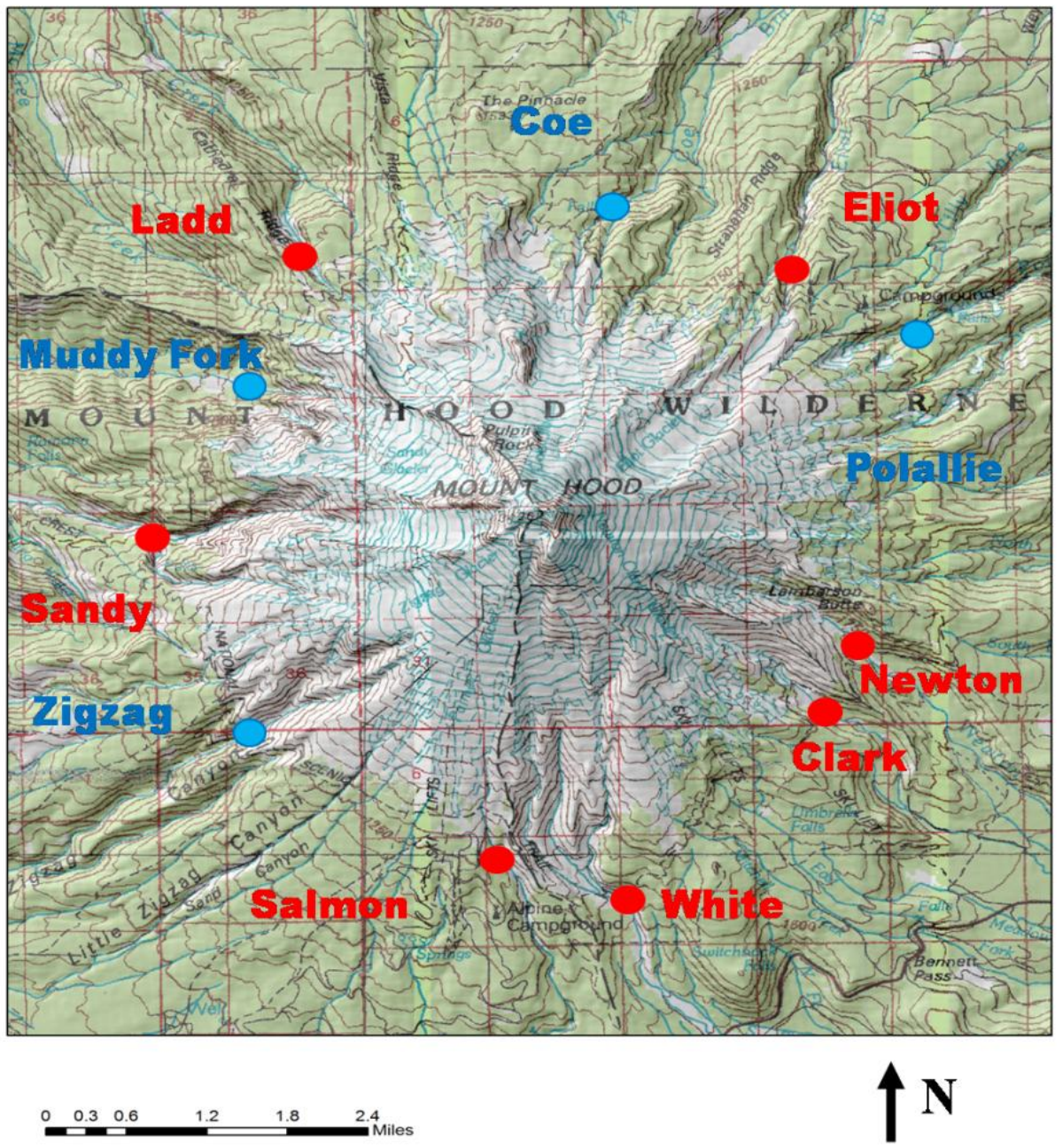

Figure 3. 2006 debris flow drainages are in red; drainages in blue did not have debris flows. 
this event can be seen on Figure 3. Five of these flows caused major damage to bridges and roadways. Highway 35, a key access route on Mount Hood, was closed in two places. As judged from the severity of this event, Mount Hood, while not currently producing new volcanic deposits, is still potentially dangerous and destructive.

\section{Summary:}

In the past, Mount Hood has been a source of both magmatic volcanic activity and numerous lahars. The volcano is capable of producing catastrophic events that could instantly and dramatically alter the topography in the region. This ability is highlighted by evidence from the prehistoric debris avalanche and the four major eruptive periods (Polallie, Zigzag, Timberline and Old Maid) known to have occurred during and since the Fraser Alpine Glaciation. Deposits from even single events, whether they are debris flows, lahars, or pyroclastic flows, can be several meters thick. The evidence from dynamic events in the past can only hint at the possible magnitude of future occurrences. Today, even though Mount Hood shows no signs of imminent volcanic activity (Gardner et al., 2000), it continues to be a source of debris flows. These flows are neither unusual nor uncommon given the history of this active volcano. Debris avalanches and lahars of enormous size have occurred in the past and are certainly possible again. These hazardous events may occur with little to no advance warning (Gardner et al., 2000). It is important for community planning and 
volcano hazard management to understand and respect the history and processes of Mount Hood.

\section{PREVIOUS DEBRIS FLOW RESEARCH}

Past debris flow research has taken on several important topics including debris flow behavior, conditions necessary to produce debris flows, mobilization of debris flows, field identification of debris flows, delineation of debris flow hazard zones and morphometric analysis of debris flow hazard areas.

Debris flow behavior has been discussed both in terms of the physics of debris flows (Iverson , 1997; Iverson , 2003) as well as evaluation and comparison of models or modes to explain the initiation mobilization of debris flows from landslides (Iverson et al., 1997). In general, it is accepted that landslides mobilize to form debris flows through three distinct processes or modes. These processes are widespread Coulomb failure within a sloping soil, rock or sediment mass, mobilization through partial or complete liquefaction of the soil by high pore fluid pressures and conversion of landslide translational energy to internal vibration energy. While individually any of these processes are capable of initiation debris flows, it is very likely that landslides mobilize to form debris flows through a combination of at least two of these distinct modes (Iverson et al., 1997). Debris flow classification has also been discussed in terms of classifying flows based on rheological boundaries and water content in which flows are located on a two 
dimensional matrix (Figure 4) according to mean velocity and sediment concentration (Pierson \& Costa, 1987).

Debris flows often develop from landslides. Conditions for landslide initiation due to antecedent rainfall are discussed by Iverson (2000). He found that failure results from rainfall over a timescale represented by $\mathrm{H}^{2} / \mathrm{D}_{0}$, where $\mathrm{H}$ represents depth and $D_{0}$ is the maximum hydraulic diffusivity, associated with transient pore pressure transmission during and following storms which can range from minutes to months (Iverson, 2000). Three methods for initiating debris flows as a result of heavy rainfall in arid and semi arid regions were discussed by Godt and Coe (2007). These methods include shallow landsliding, transport of sediment through a series of coalescing rills characterized by the erosion and entrainment of hillslope material by overland flow, and the so called "firehose effect" which is caused by the mobilization of material by a concentrated flow of water. The rilling theory is also supported by work done on post fire burn areas where it was found that the process that accelerates the stripping of material from hillslides, such as dry ravel and creation of rill networks, is greatly sped up by the action of wild fires (Cannon, 2003; Wells, 1987). The Godt and Coe (2007) paper argued that those debris flows initiated by rilling or the firehose effect were more dangerous than those initiated by shallow landsliding because shallow landslide debris flows tend to deposit material along 
their path whereas rilling and firehose debris flows tend to increase in volume as they travel downstream (Godt \& Coe, 2007).

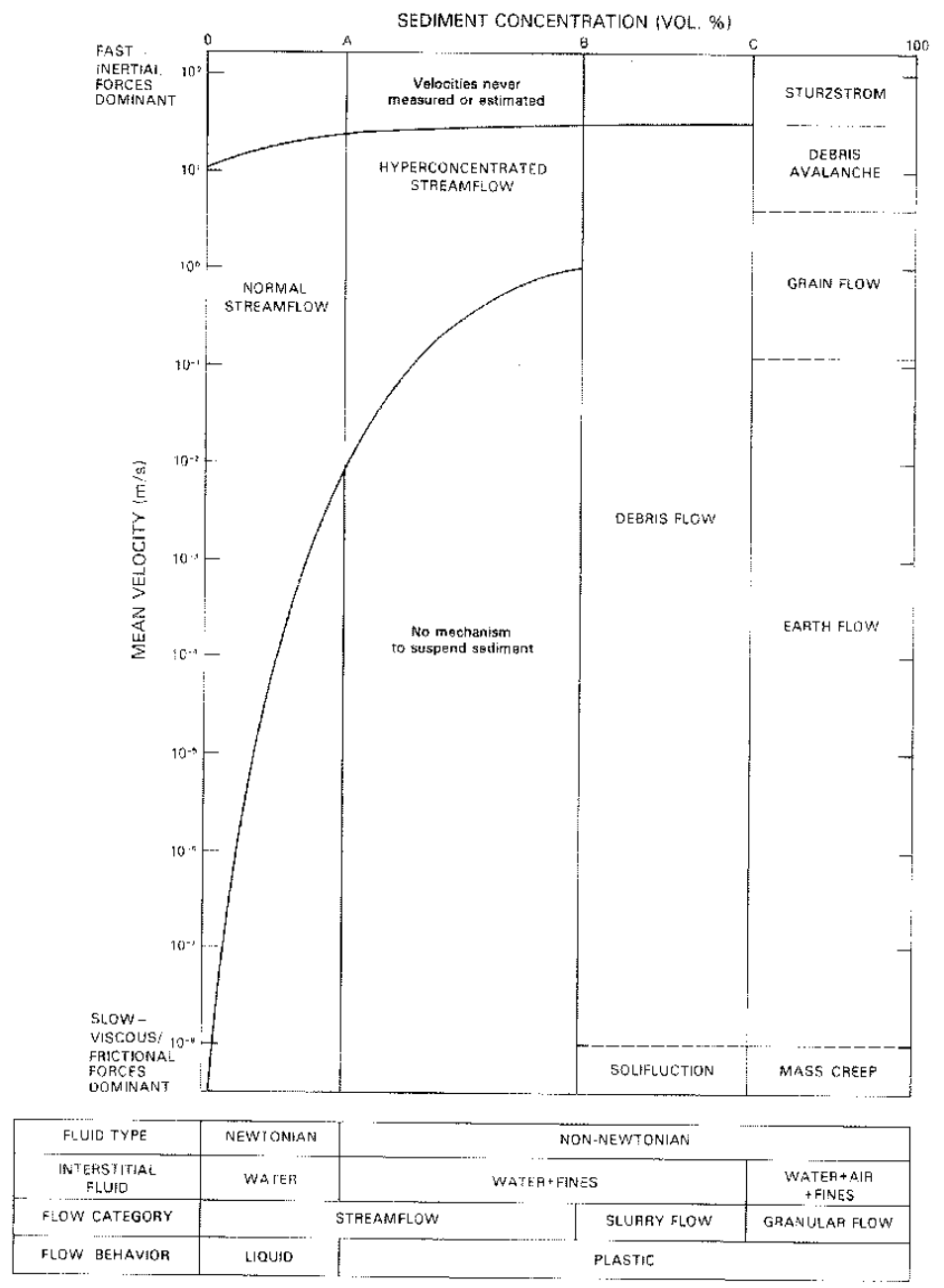

Figure 4. Existing flow nomenclature fitted into rheologic classification (Pierson \& Costa, 1987)

Occurrence of debris flows also depends on the ability of the basin in question to transport the material at a point in time when a climatic threshold is reached (Bovis \& Jakob, 1999; Carson \& Kirkby, 1972; Jakob et al., 2005). An important factor for debris flow generation is the antecedent ground conditions such as pre-storm soil 
moisture. High levels of moisture in the soil prior to a major storm can make debris flows much more likely to occur (Church \& Miles, 1987; Wieczorek, 1987).

The ability to identify debris flow deposits in the field and distinguish them from flood deposits is a critical tool when conducting field based research. Debris flows often leave indicative deposits which include features such as levees, eroded and splintered tree bark, gravel imbedded in wood, broken or splintered tree stumps, and frequent log jams or boulder clusters (Pierson, 2005). Once debris flow features have been recognized, reliance on vegetation indicators also helps to further identify and relatively date the event (Jackson et al., 1987; Osterkamp \& Hupp, 1987). Debris flows have a higher density and less sorting than water fluid flows (Rapp, 2005).

Understanding debris flow hazards is a subject that has been given much consideration. Computer based models such as LAHARZ are capable of calculating and plotting inundation limits of lahars of a given volume onto a geospatial background (Iverson et al., 1998). Logistic multiple regression analysis has also been used to build probability maps for debris flow hazards (Gardner et al., 2003). Multiple regression has been used for the estimation of debris flow magnitude and frequency (Bovis \& Jakob, 1999). Other models have been proposed to depict the hillside conditions where the ground failures led to debris flows (Wieczorek, 1987). Other efforts have focused on estimation of recurrence intervals (Coe et al., 2003; 
Bovis \& Jakob, 1999), but often rely on field based evidence that is not always available.

Some of the most compelling work for the delineation of debris flow hazard zones comes from a combination of computer analyzed morphometrics and field checking of results. Use of a ruggedness number (Melton, 1965) has proven to be both easily applied and effective (Jackson et al., 1987) and is often used in combination with other factors or computer analysis such as watershed length and fan slope (Jackson et al., 1987; Marchi \& Fontana, 2005; Wilford et al., 2004). It has been found that in general, small steep basins tend to have a higher Melton ruggedness number, than larger and less steep fluvial basins with third-order or greater streams, and are more likely to experience debris flows (Jackson et al., 1987). However, the initiation of debris flows in a basin also depends on the availability of material in the basin (Jackson et al., 1987; Marchi \& Fontana, 2005), which directly relates to the definition of a basin as either transport-limited or weathering-limited (Bovis \& Jakob, 1999; Carson \& Kirkby, 1972; Ritter, 2002). 


\section{CHAPTER 3: METHODS}

\section{Field Methods:}

The field portion of this project consisted of three phases: initial reconnaissance, detailed mapping for investigation of the initiation zone, and sample collection. Each of the major drainages coming off the mountain was investigated to determine if there had been debris flow activity as a result of the 2006 storm. Once a determination had been made on whether a recent debris flow had occurred, detailed mapping and investigation of the initiation zone was conducted for those that experienced debris flows. Sampling was conducted in all the drainages.

\section{Initial Reconnaissance:}

Initial reconnaissance was conducted on foot around the entire mountain, using the Timberline Trail as a primary access route. Inspections were made of all channels around $\mathrm{Mt}$. Hood at the approximate elevation of the timberline, about 1830 meters. Additionally, inspections were made on the flanks of the mountain, where the steep channels deposited onto fans, for those streams which did not show evidence of debris flows at or above the timberline. Debris flows were differentiated from floods using criteria developed by the United States Geological Survey (Pierson, 2005). For the purposes of this project, a flood is defined as "a high discharge, overbank flow involving either water flow at normal suspended-sediment concentrations (generally less than 5-10 percent sediment by volume), or hyper-concentrated flow (having 
from 5-10 percent to anywhere between 20-60 percent sediment by volume, depending on the relative amount of silt and clay in the fluid mixture). In both cases, flow behavior is controlled by the water. Flow behavior of debris flows, in contrast, is significantly controlled by the entrained sediment" (Pierson, 2005). In the field, debris flows and floods can be differentiated through careful observation of deposits and vegetation in the drainage. Debris flows leave behind distinct identifying morphologic features on the landscape, such as boulder levees, and also cause significantly more damage to vegetation than do floods.

Debris-flow-affected drainages were differentiated from those impacted by flooding through a variety of field-based evidence. Deposits in drainages which experienced debris flows typically have lobate margins with accumulations of coarse clasts at margins of the flow in depositional areas (Pierson, 2005). Flow levees are common and consolidated sediments can be packed in between roots in root wads, in cavities in trees and stream banks, and fragile clasts may be present on the surface. Debris flow deposits are frequently dammed locally by small log jams or boulder clusters, and sandy mud coatings can often be seen on boulders, logs, and banks (Pierson, 2005). Damage to vegetation is common in debris-flow-affected drainages and is typically severe in the thalweg of the channel, and proportional to flow velocity. Some examples of damage to vegetation from debris flows include eroded splintered wood, gravel embedded in the wood, bark remaining only on the 
downstream side of the trunk, and splintered stumps and branches tapered by erosion. Trees may be broken off near the channel axis (Pierson, 2005). Diagnostic mud coatings on vegetation also indicate the occurrence of a debris flow. The noted absence of vegetation in or near the stream channel is strong evidence of debris flow behavior (Pierson, 2007). These features, combined with severe down cutting of the stream, are especially prominent in the transportation zone of the debris flow. Other evidence of debris flows includes large clasts resting on top of a matrix supported deposit and flow levees along the sides of the channel (Pierson, 2005). Debris flow deposits are nonstratified, extremely poorly sorted with matrix filling all voids except at flow margins or where they have been washed out. Clasts are oriented randomly except at flow margins. Deposits also have a coherent, semiindurated consistency. They are difficult to dig out of outcrops and break off in small chunks when struck or kicked (Pierson, 2005)

Conversely, drainages which experience flooding commonly exhibit dunes or ripples on the deposit margins and surfaces. Surfaces may be cut by channels and scour depressions; however, gravel levees do not form (Pierson, 2005). Floods do not leave mud coatings on boulders, logs, or banks and gravel clasts may be imbricated. Low density flotsam such as wood debris may be found at the edge of the flow as well as grass or other debris in tree branches (Pierson, 2005). Damage to vegetation is normally moderate to light, however can be severe in canyons. Erosion 
of tree bark is normally light and irregular with finer branches commonly bent but not broken or stripped. Flattened grasses or other vegetation may also be present near the channel (Pierson, 2005).

Hyper-concentrated flood deposits represent an intermediate in-between a debris flow and a flood (Pierson, 2005). Water flood deposits are usually stratified showing distinct laminae and beds, commonly with cross bedding, while hyperconcentrated flood deposits show faint horizontal to massive bedding with outsized individual gravel clasts and lenses which sometimes appear as massive but poorly consolidated diamictons (Pierson, 2005). Water flood deposits have a loose and friable consistency when dry with hyper-concentrated flow deposits slightly more consolidated (Pierson, 2005).

Observation of vegetation in and around the stream channel was especially useful for determining recent debris flows from past flows. In the summer of 2007 , no new vegetation would have had a chance to re-establish in the wake of the November 2006 debris flows. Those debris flow deposits that had young trees and plants growing from them were not considered to have been caused by the November 2006 storm. This distinction is especially important and cannot be assessed without direct in-channel, field based observations. Mt Hood and other mountains of the Cascade Range, have relatively frequent debris flows. In order to focus on one particular storm event, in-channel field based investigations are necessary to determine the 
relative age of a deposit. This is not something that can be detected remotely or even from a simple vantage point on the trail. Field checking and compilation of field based evidence is critical for an event-specific investigation of debris flow activity.

After field based evidence had been applied to determine whether a drainage had been impacted by a debris flow or flooding, the initiation zone was defined for those debris-flow-affected drainages.

\section{Detailed Mapping of the Initiation Zone:}

Identification of the initiation zone for debris flows on Mount Hood was determined by physical inspection. Once a drainage had been determined to have produced a debris flow in the November, 2006 event, an inspection of debris flow features including boulder levees, scour in the channel, and lack of vegetation was conducted upstream. The initiation zone was defined as the point at which there was evidence of debris flow activity downstream from that point; there was a lack of evidence for debris flow activity upstream from that point. Photographs were taken of all upper drainage areas to document the basin morphology as well as initiation zones and processes.

In four out of seven drainages that had debris flows, these initiation zones showed evidence of landslide activity in the channel sidewalls. Where landslides were identified as the initiation source, measurements of the width across the side scarps were taken with a laser range finder as well as measurements from the top to 
bottom of the slope. These measurements were combined with an estimated depth to approximate volume of the slide. The depth was either measured directly with the laser range finder, or approximated as an average from those that were able to be directly measured. Those areas that did not exhibit evidence of landsliding as the initiation mechanism, I have named "headless debris flows". These so-called headless source areas typically exhibited rilling and scouring consistent with overland flow of water and often showed minor debris tracks and trails streaking across a hillside. These debris trails would coalesce in the channel, and subsequently downstream there would appear major evidence of down cutting from debris flow activity (Figure 5). GPS points were also taken at the initiation zones for all debris flows and used in combination with LIDAR data to identify initiation zone elevations. GPS positions are given in UTM zone 10.

\section{Sample Collection}

In order to determine whether a difference in material type led some drainages to have debris flows and not others, samples were collected from all main drainages around the mountain. Bulk density measurements and grain size analysis were used to characterize the samples. For those drainages which experienced debris flows, sediment samples were collected from the initiation zone or geologic material representative of initiation zone material. For those drainages which did not 
experience debris flows, samples were collected within an elevation range consistent with where the initiation zones for the debris flow producing drainages

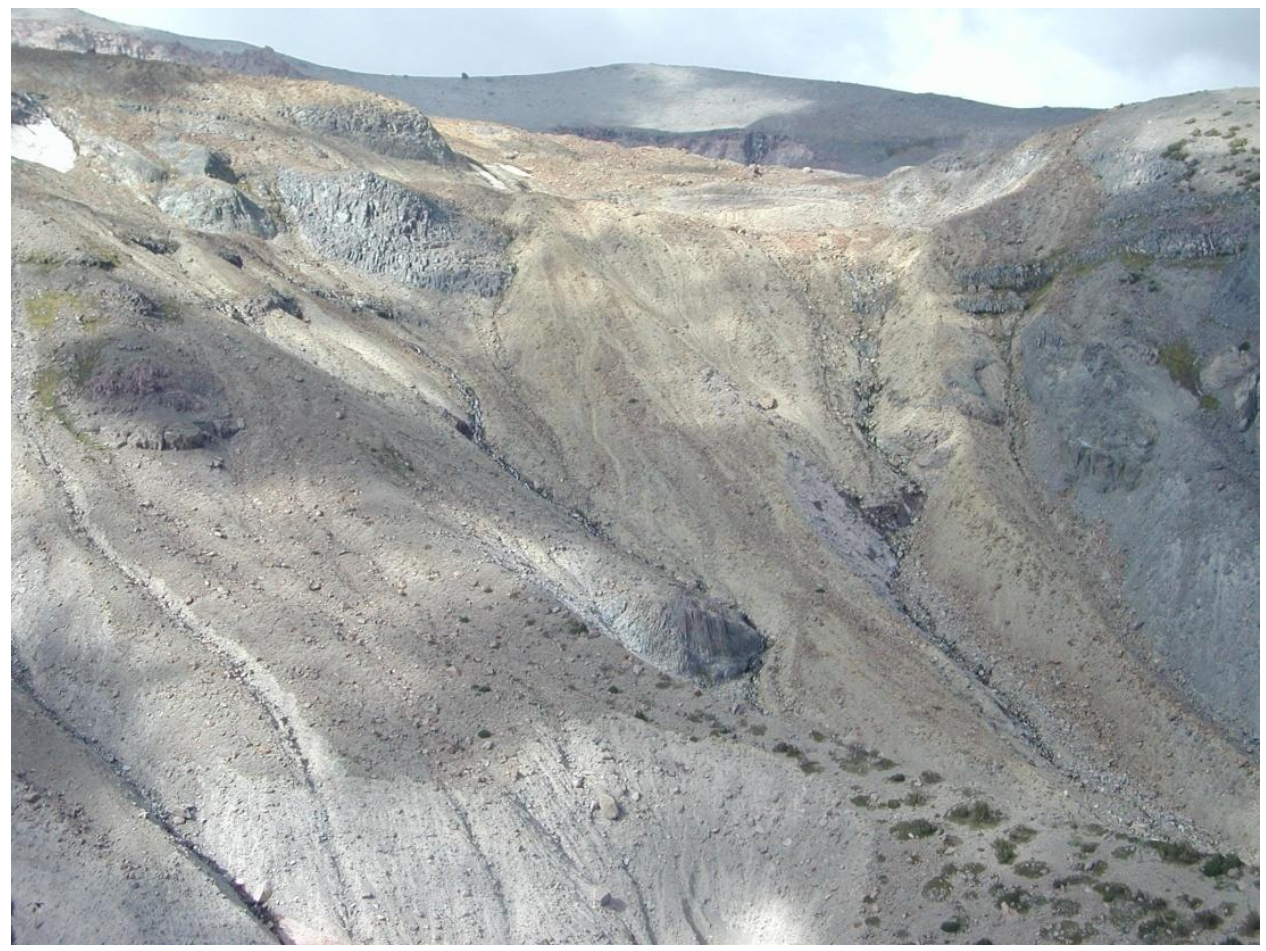

Figure 5. Headless debris flow trails in Newton Creek Drainage.

were found. Six soil samples, with an average volume of $670 \mathrm{ml}$, of only less than cobble sized particles, were taken from every site to be later used in sieve analysis. Additionally, estimates on material bulk densities were made using a method described by Tom Pierson in personal communication. This method called for careful excavation of material, using a small shovel, from a hole. The subsequent hole was then lined with plastic and water was poured from a container of known quantity. The amount of water used to fill the hole was measured. This measurement when 
combined with the dry weight of the excavated sample provided an estimate of material dry bulk density. An example of a hole is shown in Figure 6.

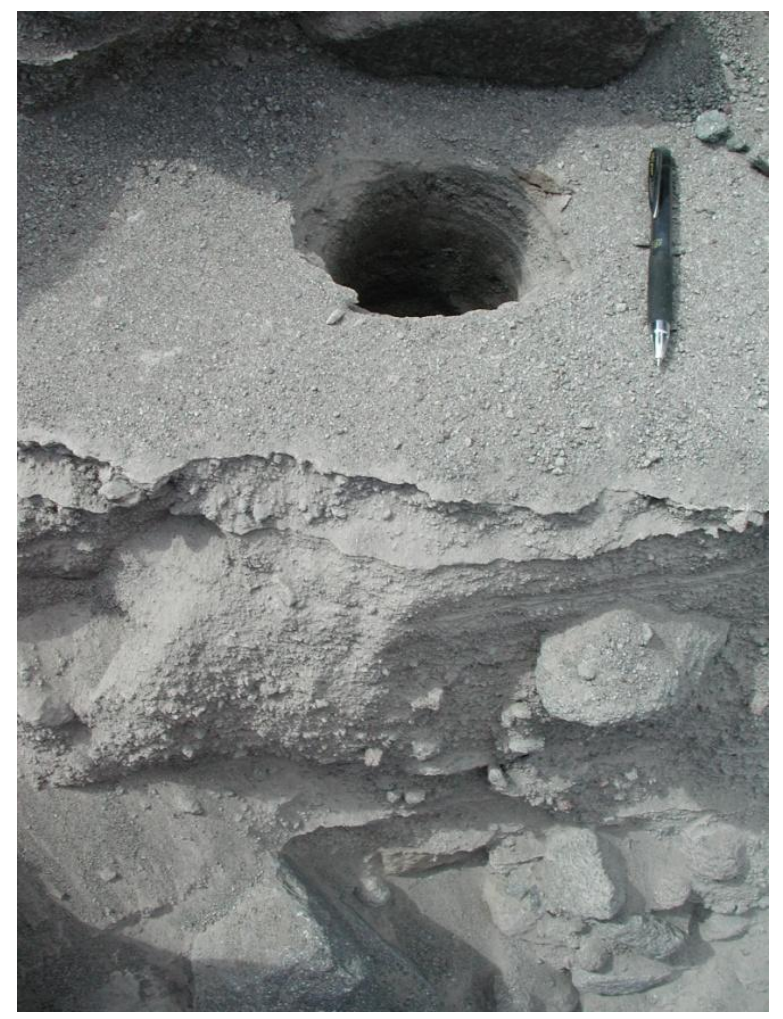

Figure 6. Sample collection hole from the White River Drainage (UTM 0602484N, 5019919E)

\section{Data Processing:}

\section{Laboratory Sieve Analysis:}

Sieve analysis was conducted by first air drying each sample, weighing it and then putting it through a stack of sieves. Samples were sieved using a $10,30,60,100$, 200 , and 230 sieve. Wet sieving was not conducted due to the very low percentages of fines revealed by the dry sieve method. The stack was placed on a shaking machine and left to shake for approximately 10 minutes. At the end of the allotted 
shaking time, the amount of sample remaining on each sieve was collected and weighed. All grains that did not pass through the number 10 sieve, greater than 2 $\mathrm{mm}$, were classified as gravel. Sand was considered any grains that passed through the number 10 sieve but did not pass the 230 sieve, between $.063 \mathrm{~mm}$ and $2 \mathrm{~mm}$. Any particles that passed through the 230 sieve, less than $.063 \mathrm{~mm}$, were considered silt \& clay. The sand was further broken down into coarse, medium and fine grain sizes. Sand particles that did not pass the number 60 sieve, or were greater than $.25 \mathrm{~mm}$ in diameter were considered coarse. Sand grains that passed the 60 sieve but did not pass the 100 sieve, between $.149 \mathrm{~mm}$ and $.25 \mathrm{~mm}$, were considered mediumgrained sand. Grains that passed the 100 sieve but did not pass the 230 sieve, between $.063 \mathrm{~mm}$ and $.149 \mathrm{~mm}$, were considered fine-grained sand. Particles passing through the 230 sieve were classified as silt and clay.

\section{Rainfall Data}

Rainfall data were obtained from three different sources. Data for initiation elevations were obtained from a compilation map of NEXRAD (Next Generation Radar) Storm Total Data for the November 2006 Storm provided by Todd Parker, USFS hydrologist for Mount Hood, and from North West Avalanche Center rain gauges at Timberline and Mount Hood Meadows ski areas. For lower elevations, data was taken from SNOTEL Sites

(http://www.wcc.nrcs.usda.gov/snotel/Oregon/oregon.html). 
NEXRAD data are collected with radar which sends out a high burst of energy. When the energy strikes an object such as rain or hail, it sends a return back to the radar unit. The larger the particle, the stronger the radar return. Since hail can cause returns with indicate that rainfall is more than what is actually occurring, steps can be taken through manipulation of the computer processing to prevent extremely high values from being converted into rainfall (NEXRAD, 2009). The radar unit used to collect data for the November, 2006 storm is located in Portland, Oregon. The storm total data are presented as a compilation image of estimated accumulated rainfall for the entire duration of a storm event. The maximum range of this product is about 198 kilometers from the radar unit (NEXRAD, 2009). One significant disadvantage of NEXRAD is that rather than a direct measurement, it provides an estimated intensity or rainfall amount. However, the data offer complete and uniform coverage of the study area and for this reason were used in the statistical analysis.

North West Avalanche Center (NWAC) rain gauges were also examined as part of this study. These precipitation gauges give direct rainfall amounts in addition to providing snowmelt information for the Timberline and Mount Hood Meadows ski areas. In general, it was noted that the NEXRAD data under-reported the storm precipitation compared to the NWAC gauges by 33 to 38 percent. This could be due to adjustments taken to minimize the impact of hail on the radar which effectively 
blocks very high returns from being counted as rainfall data. Therefore, NEXRAD data were considered a minimum value for the purposes of this study.

While NEXRAD storm total data provided minimum rainfall estimates for the upper elevations on the mountain, SNOTEL sites provided additional information on rainfall at the lower elevations. The three SNOTEL sites closest to Mt Hood are Red Hill, Mount Hood, and Blazed Alder stations. The Red Hill station is located on the north side of the mountain at elevation 1,344 meters. The Mount Hood station is located on the south side of the mountain at elevation 1,637 meters. The Blazed Alder station is located on the west side of the mountain at elevation 1,113 meters. All SNOTEL sites provide information on precipitation, snow depth, snow water equivalent and temperature. The precipitation information is captured using a precipitation gauge that is sized according to the average annual precipitation at each station. The fluid pressure is measured with transducers and recorded.

\section{Drainage Basin Attributes:}

I wanted to investigate different attributes that might contribute to the initiation of a debris flow. A list of 16 was arrived at by consulting the literature and what others said about initiation. Others were arrived at as possible sources in consultation with my advisors. I have described these below.

Lidar data used for this project was obtained from Watershed Sciences in cooperation with the Oregon University System. Processing for LiDAR data was done 
using ArcGIS 9, ArcView 9.3 and Extensions, student edition. LiDAR data were stored on a Western Digital $250 \mathrm{~GB}$ external hard drive, and the Arc GIS program was run on a Dell Inspiron 1420 laptop computer.

- Elevation of initiation zone was calculated by two methods. For those drainages which had a landslide as the initiation trigger, LiDAR based terrain data were evaluated at the upper and lower most points of the landslide scarp to provide an elevation range for the initiation zone. For those drainages which experienced headless or non-landslide initiation debris flows, the initiation was measured as the elevation of the first evidence of debris flow activity in the channel. This typically was exhibited as large scale channel scour consistent with debris flow activity.

- The total basin catchment area of each primary drainage basin was calculated by outlining the basin using LiDAR derived data and creating a new shape file in ArcGIS. The outline for the shape file began at the top of the basin. It followed the ridgelines down until the river reached a place where the primary stream within the basin intersected another stream whose upper area was not already included in the basin shape file outline. The shape file outline was then closed typically at the fan where the two streams met. The area was calculated for the shape file thereby giving an overall basin catchment area in square meters. 
- The upper drainage basin area is nested within the total basin catchment and is a subset of the total basin. The upper drainage basin follows the ridge lines from the top of the total basin, past the initiation zone, and pinches off at the first natural narrowing of these ridge lines after the initiation zone. The point in the stream, below the initiation zone, where the ridge lines narrow is defined as the bottom of the upper basin. The upper drainage basin includes the entire area upstream from that point. The initiation zones fall within the upper basins, but the basins are not defined by them. Shape files were created for each basin and areas were calculated in square meters for each of these shape files. Initiation zone elevations were typically found between $1520 \mathrm{~m}$. to $1,830 \mathrm{~m}$. For those basins which did not experience debris flows, a point was chosen in the stream, below these elevations, where a natural constriction occurred in the ridge line. The upper drainage basin for these streams includes the entire area upstream from that point.

- Distance from the glacier was calculated using spatial analyst tools in ArcGIS. The distance from the glacier was calculated as the distance from the terminous of the glacier to the lowest elevation of the initiation zone or the first evidence of erosion for headless debris flows. This was measured along the thalwag of the stream channel and not "as the bird flies". 
- Glacier area was either calculated from previous glacier shape files (Jackson \& Fountain, 2007; Jackson K. M., 2007) or compiled through existing data from the USGS (Driedger \& Kannard, 1986).

- Area above the initiation zone was calculated for those drainages that experienced debris flows. It was calculated in ArcGIS using spatial analyst tools. This area was calculated starting at the initiation zone and encompassing the upper drainage basin which drains to the initiation zone.

- Sediment type was characterized by geologic units present in the initiation zones. Geologic units were obtained through examination of the preliminary geologic map of Mount Hood (Sherrod \& Scott, 1995). Predominant sediment types were till of neoglacial age, pyroclastic flow and debris flow deposits.

- Rainfall data were obtained for initiation elevations from a compilation map of NEXRAD Storm Total Data for the November 2006 Storm provided by Todd Parker, USFS hydrologist for Mount Hood. Although these data may under-report total storm rainfall amounts during high intensity rainfall, it is the only consistent data source that covered all of the initiation zones and was therefore used as a factor in statistical analysis.

- Azimuth for each initiation zone was calculated manually from a hillshade map of Mount Hood based on LiDAR derived terrain data. Azimuth was 
calculated from the top to the bottom of the upper drainage basin as degrees from north with a range of 0 to 360 .

- Surface water connection to the glacier was determined based on information provided by Tom DeRoo, the USFS Geologist for Mount Hood, along with in field observations. Each basin was determined to be either directly connected to the glacier (water could be seen directly flowing from the glacier into the active stream channel) or not connected to the glacier (Tom DeRoo indicated the drainage was fed by groundwater and no observable connection to a glacier was noted in the field). When used for basin analysis, this factor is defined as either yes, connected to the glacier, or no, not connected.

- Basin height for the drainage basin is a parameter used in Melton's Ruggedness number and was calculated in ArcGIS using LiDAR derived data. Basin height was determined by subtracting the elevation of the apex of the first major fan encountered in the total basin catchment area (as you move from the top to the bottom of the basin) from the elevation of the highest point in the basin.

- Gradient of the upper drainage basin was calculated using spatial analyst tools in ArcGIS. Gradient was determined by subtracting the stream elevation at the lowest point in the upper basin from the upper most stream elevation. The first point at which channelized streamflow activity 
could be recognized in the upper basin was defined as the upper most stream elevation.

- Percent Bedrock in the upper basin: In order to determine percent bedrock, I created a slope map for the upper drainage basin ArcGIS. Based on my observations in the field, bedrock will typically have very high slope angles (over $60 \mathrm{deg}$ ). This gives a good indication of which areas, on the slope map, may be bedrock. However, recent erosion, especially erosion into pyroclasitc or debris flow deposits, can exhibit high slope angle numbers and not all bedrock exhibits steep angles. Crevasses on glaciers will also exhibit very high angle slopes. Glaciers appear smooth looking with crevasses showing up as cracks across smooth areas. Actual bedrock outcrops have a rougher appearance. A visual check done on site photos and the hillshade of the area in ArcGIS helped confirm which areas are rock. Once bedrock areas were identified, a file geodatabase was created to store individual feature class areas from each basin. A feature class was created by carefully outlining the rock outcrops in each upper drainage shape file. Once all bedrock outcrops were outlined as polygons, the area in square feet was added up for every polygon in the feature class. The total number of square footage of bedrock outcrop was then divided by the total square foot area of the upper drainage shape file to yield a bedrock percentage. 
- Percent Vegetation in the upper basin: Calculation of percent vegetation for the drainage basins on Mount Hood was conducted using LiDAR derived terrain data. For the purposes of this study, trees and tall brush were what was predominantly considered "vegetation" as these plants are what is picked up by Lidar imaging. Vegetated areas were identified by creating a height image. This was accomplished by comparing the bare earth return digital elevation model with the first return digital surface model to derive the heights of features on the ground. Because all areas investigated are within national forest or wilderness land, it was assumed that all features which contribute to the height model are natural vegetation and not man-made structures. Once the height image was created, vegetated areas were outlined as shape files in order to calculate area. The area of the shape files was compared to the upper basin area in order to obtain percent vegetation by basin. Vegetation shape files were subjected to a visual comparison of air photos and photographs of the upper drainage basin taken in the field, to confirm and ensure accuracy of mapped vegetated areas.

- Percent steep slopes of the upper basin: Steep slopes were classified as un-vegetated, non bedrock slopes above 33 degrees. In order to determine a percentage of steep slopes by basin, a slope map was created from the LiDAR derived bare earth terrain data. Shape files representing 
bedrock and vegetated areas were overlain on the slope map so that only un-vegetated non-bedrock areas were examined. Slopes displaying an angle of over 33 degrees were outlined as shape files, and the areas were calculated. These areas were compared to the overall area of each drainage basin to obtain percent steep un-vegetated slopes by basin.

- Melton's Ruggedness Number: Melton's Basin Ruggedness number has been used to differentiate between basins that produce debris flows compared to those that produce fluvial flows. The measure of basin ruggedness (Eq. 1) is calculated by combining basin area $\left(A_{b}\right)$ and basin height $\left(H_{b}\right)$ according to Melton's equation (Melton, 1965):

$$
R=H_{b} A_{b}{ }^{-.5}
$$

Basins exhibiting $\mathrm{R}$ values of more than .25 to .3 are interpreted to be predominantly debris flow producing basins (Jackson et al., 1987). $\mathrm{R}$ values of less than .25 to .3 are generally interpreted to be predominately fluvial process driven drainages (Jackson et al., 1987). 


\section{CHAPTER 4: RESULTS}

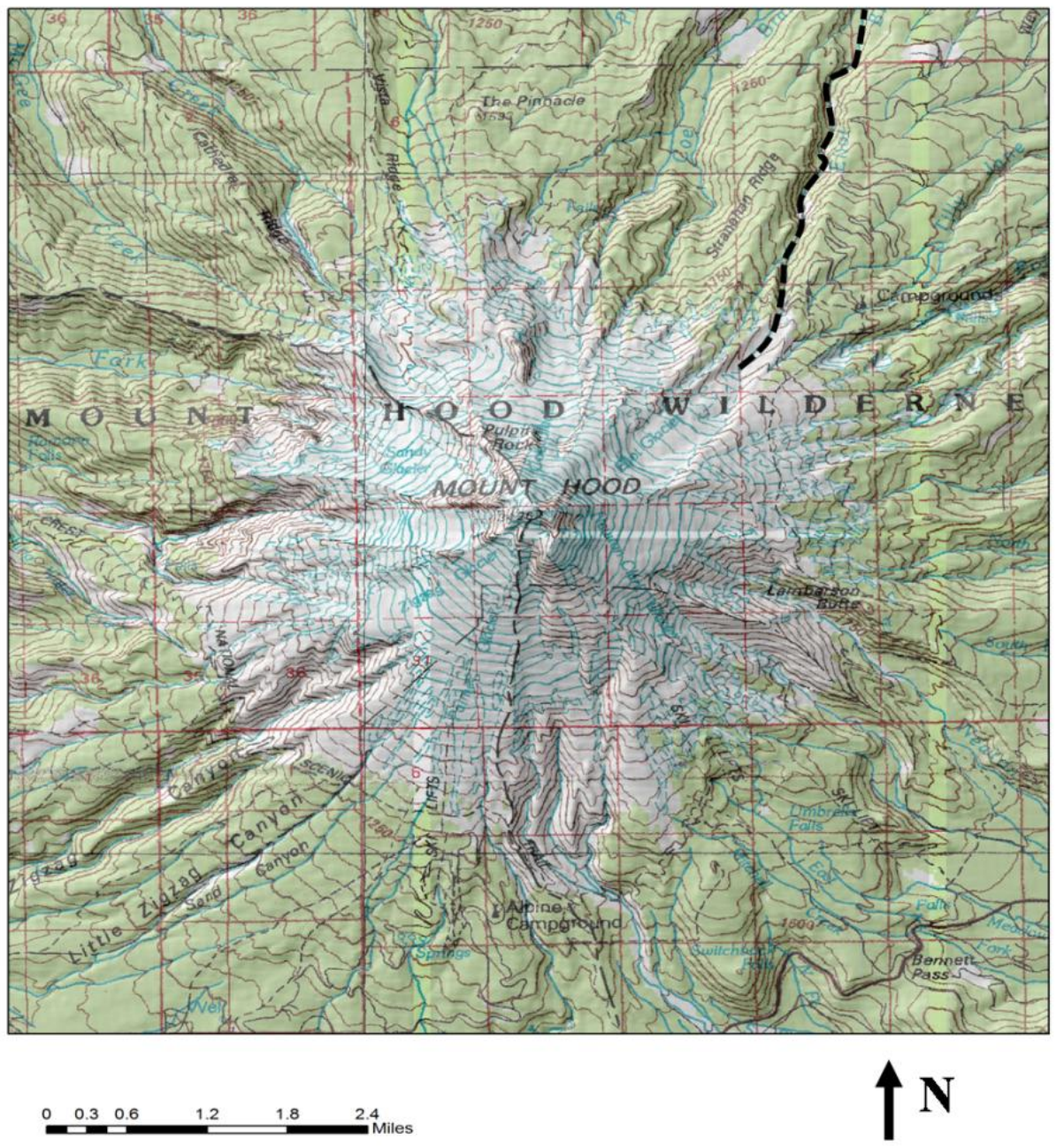

Figure 7. Eliot Creek shown in dashed black

\section{INTRODUCTION}

Each major drainage around the mountain was investigated for evidence of recent (November, 2006) debris flows. The investigation consisted of two distinct parts: field based mapping and sample collection along with data processing. The field based portion of the investigation involved an initial reconnaissance to determine the presence or absence of debris flow activity in a given drainage. Then, 
detailed mapping and sample collection in the initiation zone area was conducted. Data processing involved sieve analysis of samples collected in the field, and data analysis using ArcGIS in combination with LiDAR data for the upper drainage basins. The results of these findings are presented below. Lidar maps for each drainage basin are found in appendices $A-L$ giving : upper drainage basin area, initiation zone, vegetation extent, bedrock distribution, and steep slope distribution.

\section{ELIOT CREEK DRAINAGE BASIN:}

Eliot Creek is located on the north side of the mountain (Figure 7). The Eliot Creek Drainage experienced one of the largest debris flows, travelling approximately $16 \mathrm{~km}$, as a result of the November, 2006 storm. The first evidence of debris flow occurrence came in the form of news reports from February $6^{\text {th }}$ indicating that a road was closed due to bridge out on Eliot Creek as of 2:23pm (KATU, 2006). The subsequent investigation into the Eliot Creek Basin included field based reconnaissance, sample collection and data processing.

\section{Reconnaissance \& Sample Collection:}

\section{Initial Reconnaissance}

Evidence for debris flow activity was first encountered where Laurance Lake Road crosses Eliot Creek on the north side of the mountain. Large unsorted bouldery deposits had previously covered the road and were bulldozed to the sides (Figure 8). Deposits are unsorted and matrix supported with large boulders on top. The bridge 


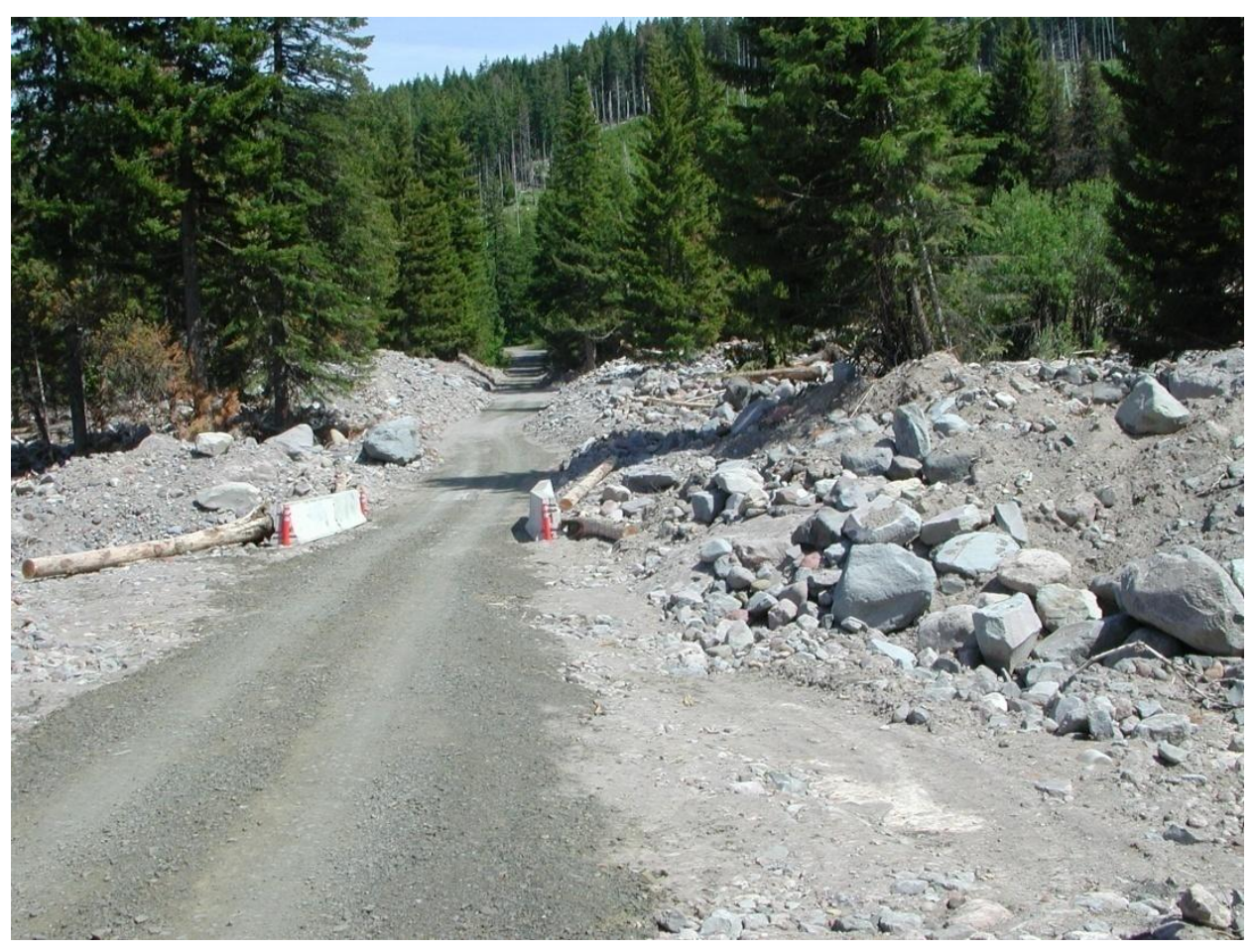

Figure 8. Laurance Lake Road at Eliot Creek crossing

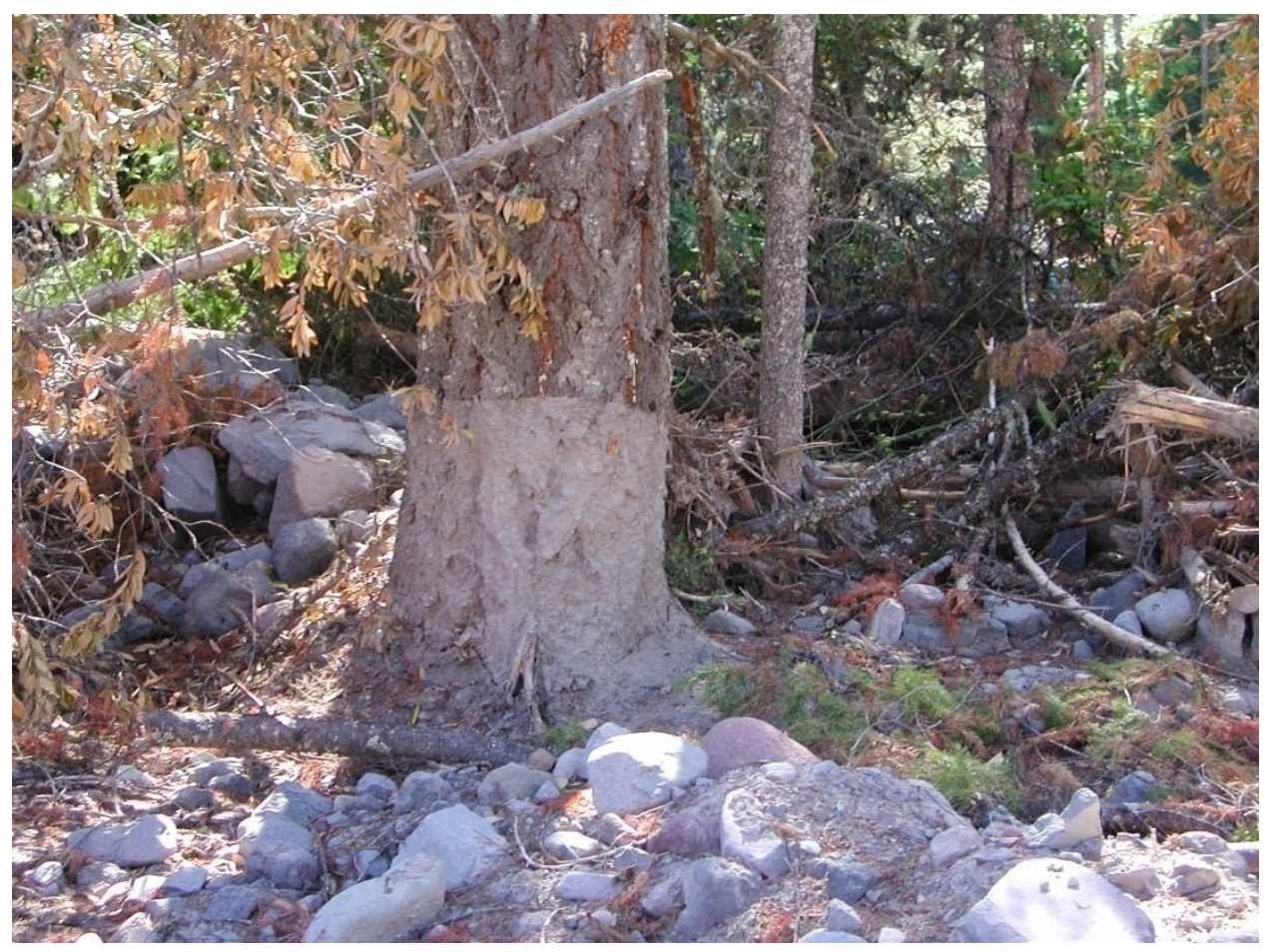

Figure 9. Mud coating on tree near Laurance Lake Road. 


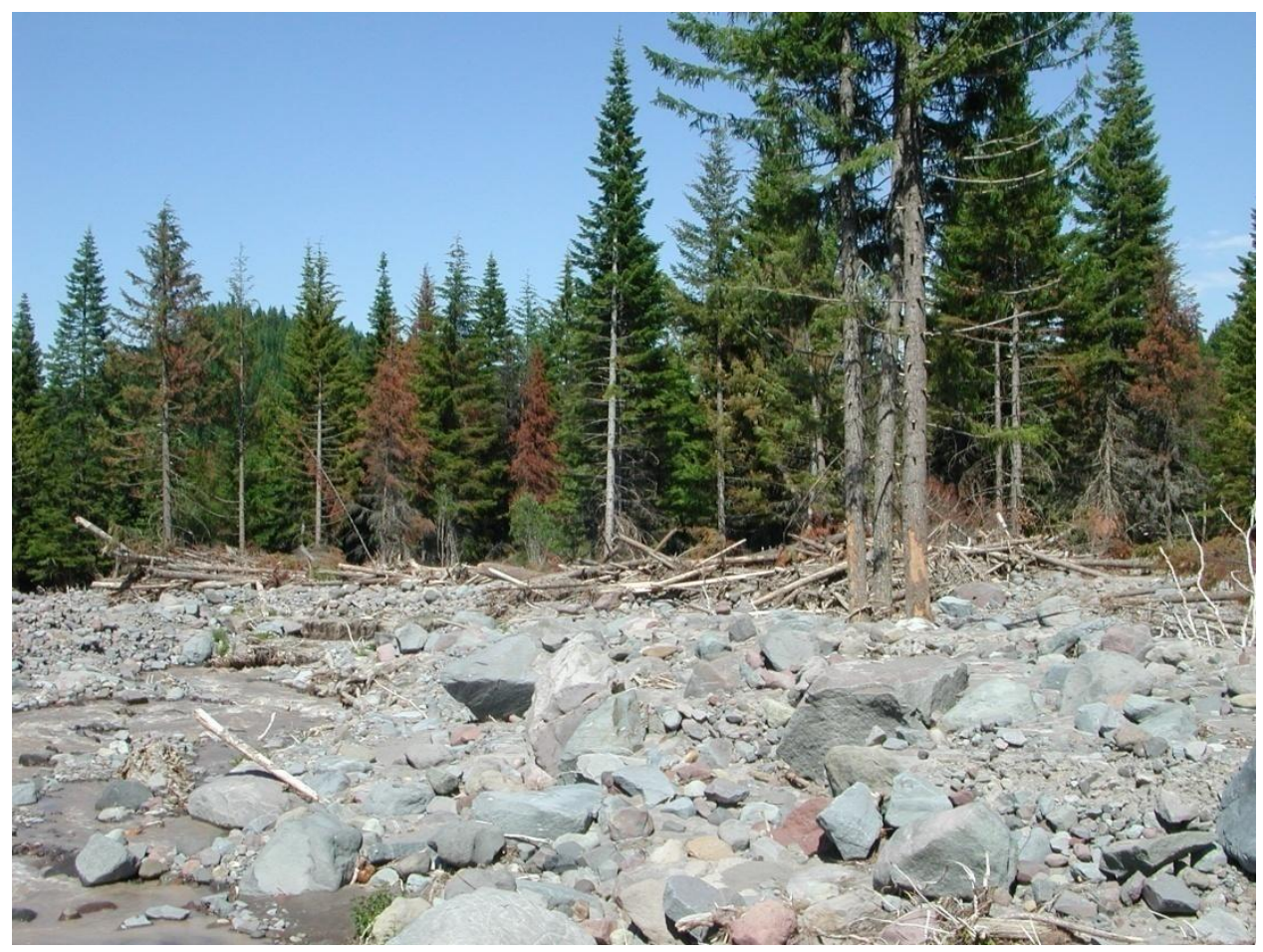

Figure 10. Log jams and trees stripped of bark just south of Laurance Lake Road.

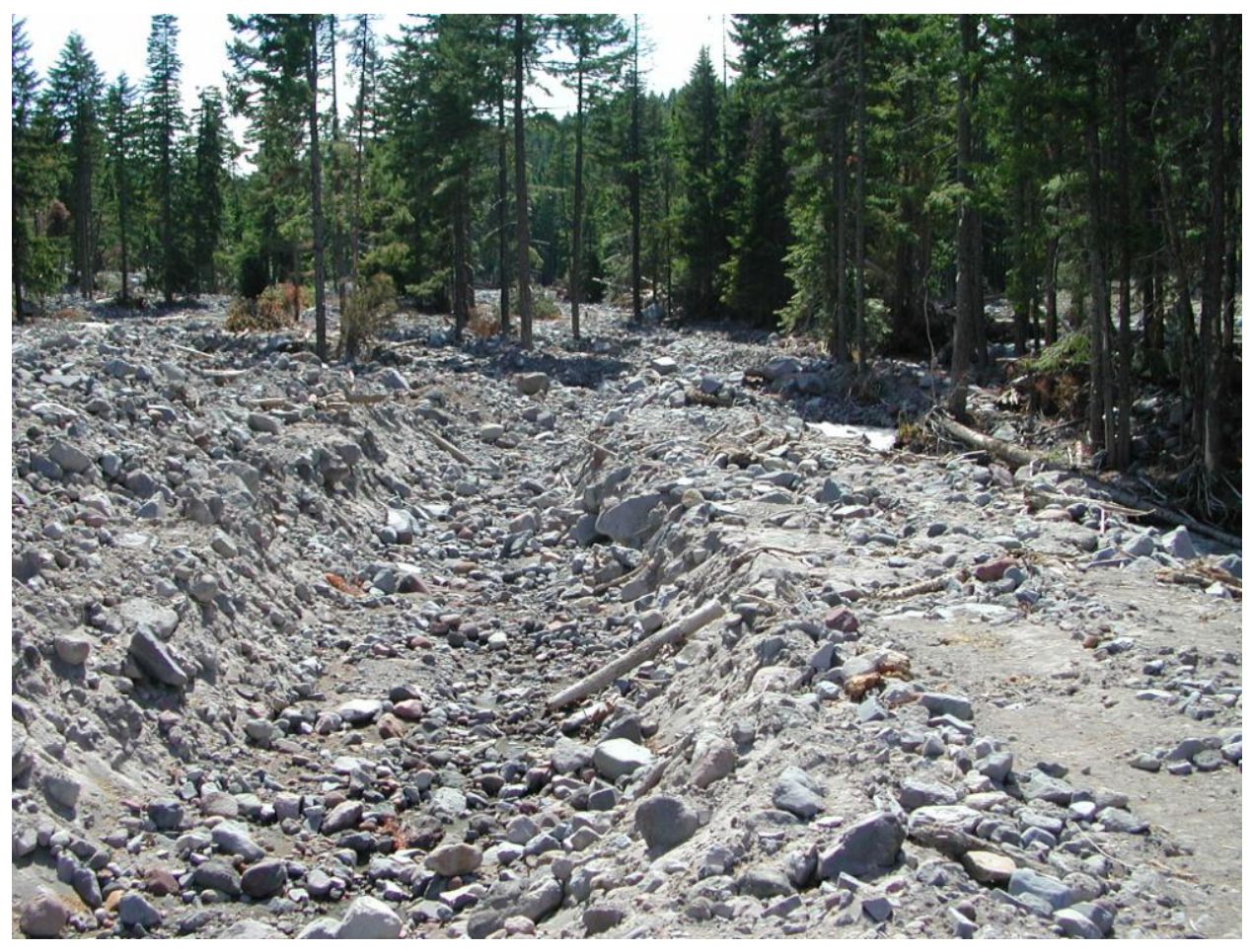

Figure 11. Abandoned channel in the fan next to Eliot Creek near Laurance Lake Road. 
which previously traversed the creek had been moved and partially buried by debris.

Evidence of debris flow activity included the presence of mud marks on trees (Figure 9), log jams, gravel sized rocks embedded in trees, bark ripped and shredded, and trees sheared off (Figure 10). Abandoned channels were present (Figure 11), and buried vegetation was visible along the newly eroded stream course. Deposits looked fresh, light colored in comparison to surrounding terrain. The water intake structure of the Hood River Irrigation district on Eliot Creek was removed and damaged beyond repair (Figure 12). The channel was cleared of vegetation (Figure 12).

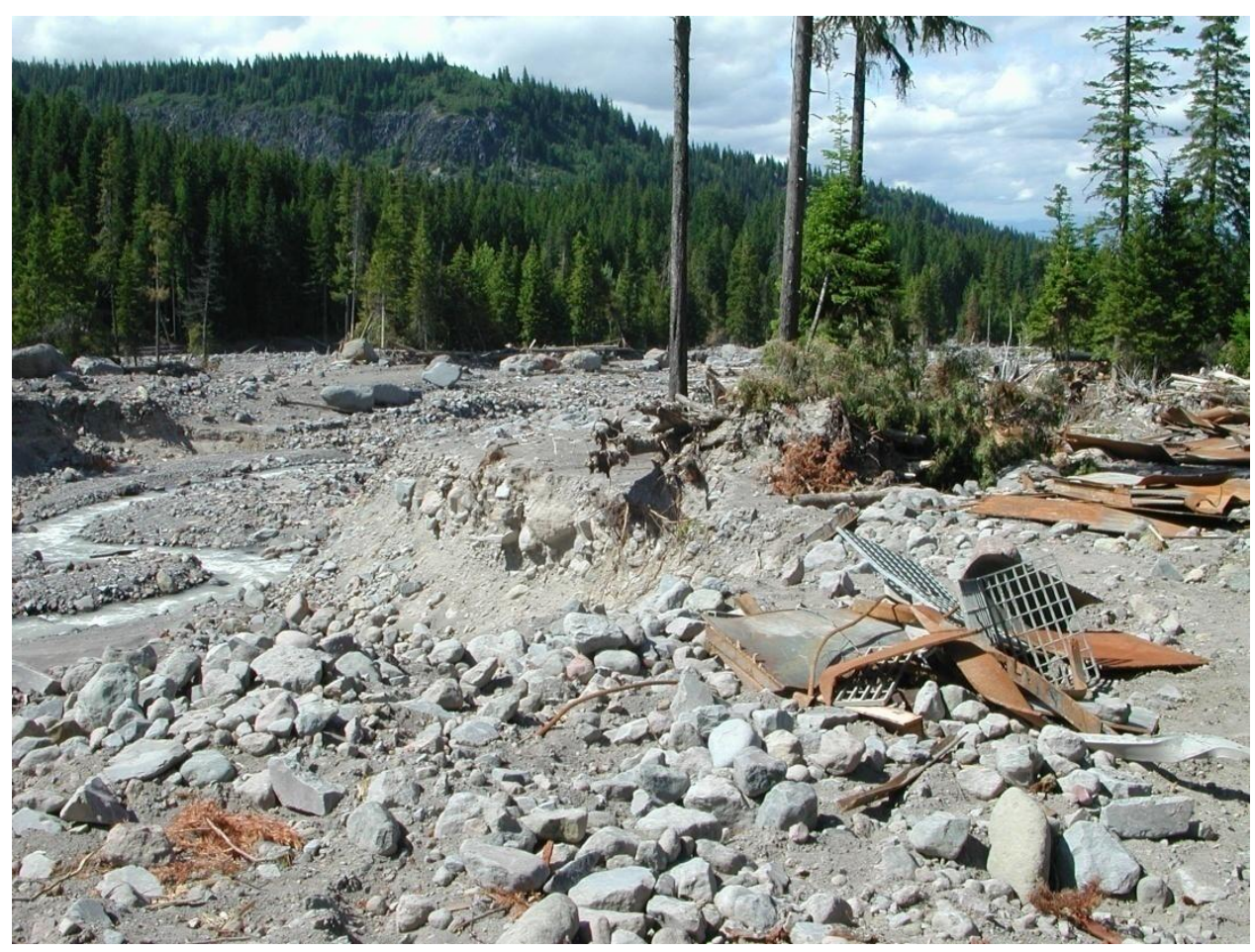

Figure 12. Damaged water intake structure for Hood River Irrigation District on Eliot Creek. 


\section{Definition of Initiation Zone}

Below the Eliot Glacier, at a constriction point where two lateral moraine walls come close together, large landslide scarps provided evidence for recent landside movement. Two major slides were identified with some minor slides present. Slides were present in both sidewalls of the lateral moraine deposits (Figures 13 and 14). Slides were identified by classic landslide features such as a prominent head scarp and sidewalls as shown in Figures 13 and 14. Slide material had been evacuated downstream. All vegetation was cleared downstream of slide area. Wet spots were identified at the base of the slide. These are interpreted to be evidence of the melting of ice-cored moraine within the glacial till. Eliot Creek also meanders into the base of each slide. Downstream from slide area, debris flow features were consistently identified by lack of vegetation and distinct color alteration showing fresh deposits and boulder levees. Upstream from slide area the terrain widened out into typical glacial terminus morphology. No evidence for boulder levees or other debris flow distinguishing features were distinctly identified upstream from the slide area.

\section{Sample Collection}

Six samples were collected from the same morainal material that the initiation landslides occurred in. The samples were taken several meters upstream from the head scarp as shown in Figure 15. 


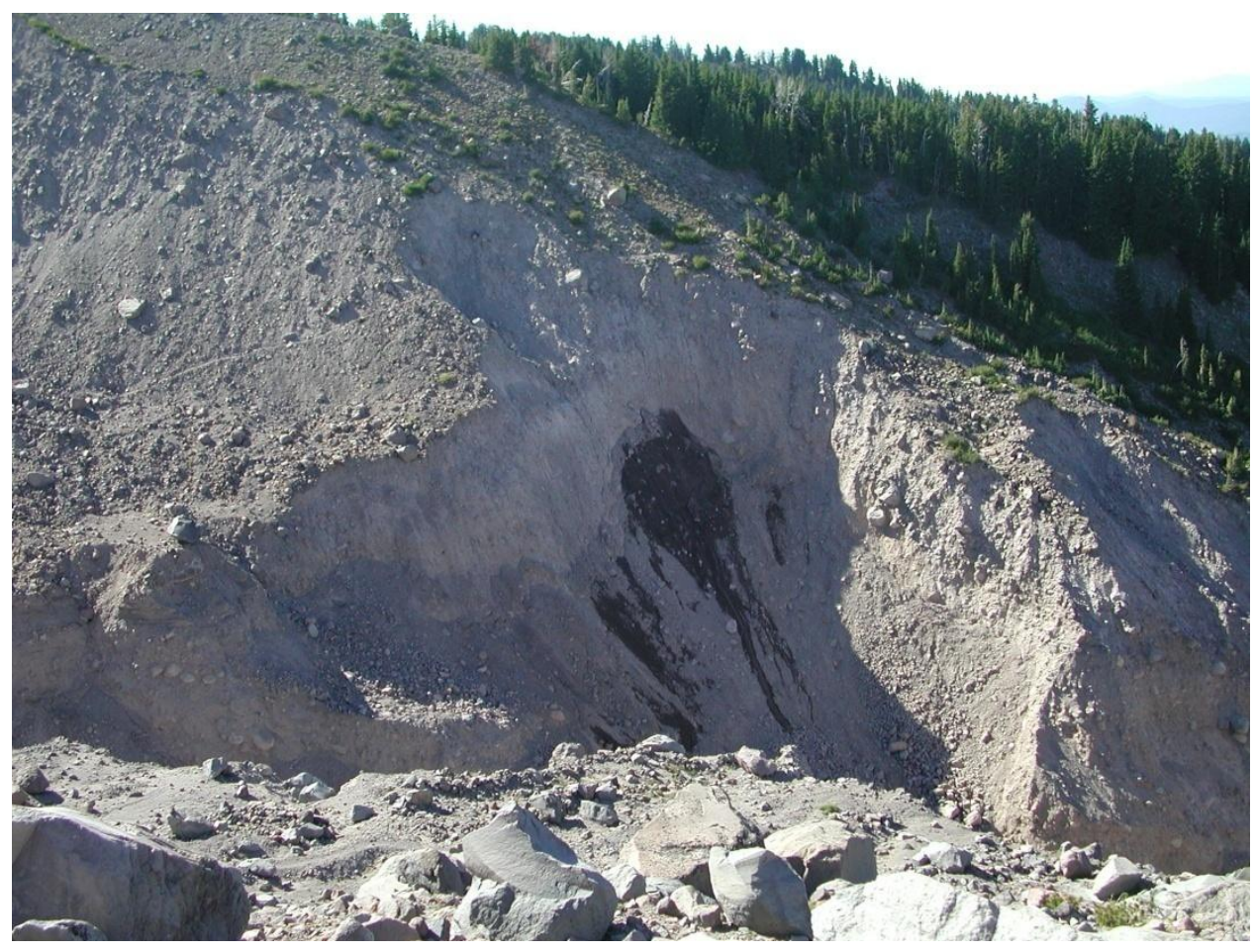

Figure 13. Eliot Creek landslide $\left(\sim 273,000 \mathrm{~m}^{3}\right)$ in west lateral moraine (UTM 0604827N, 5028150E)

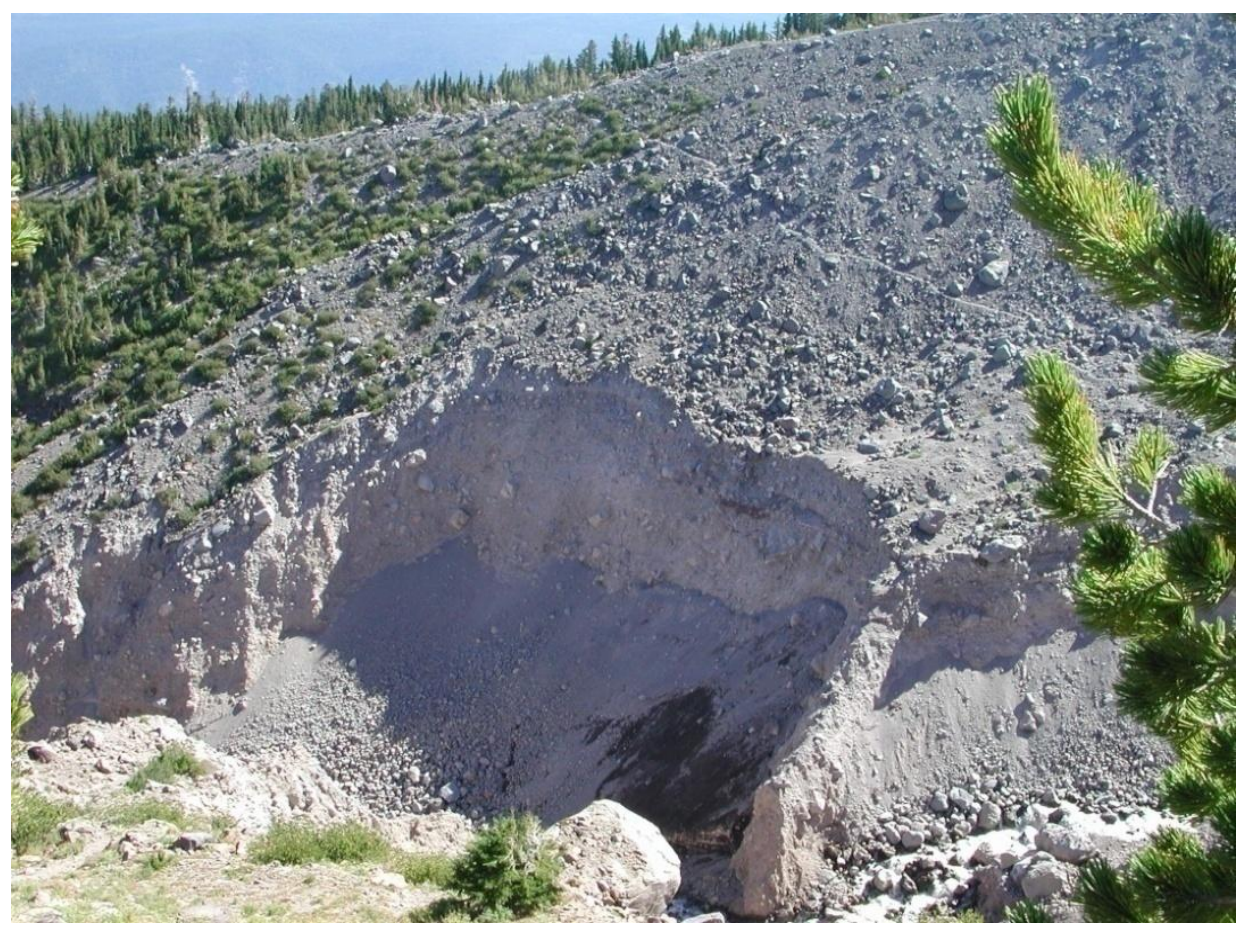

Figure 14. Eliot Creek landslide $\left(\sim 230,000 \mathrm{~m}^{3}\right)$ in east lateral moraine (UTM 0604976N, 5028133E) 


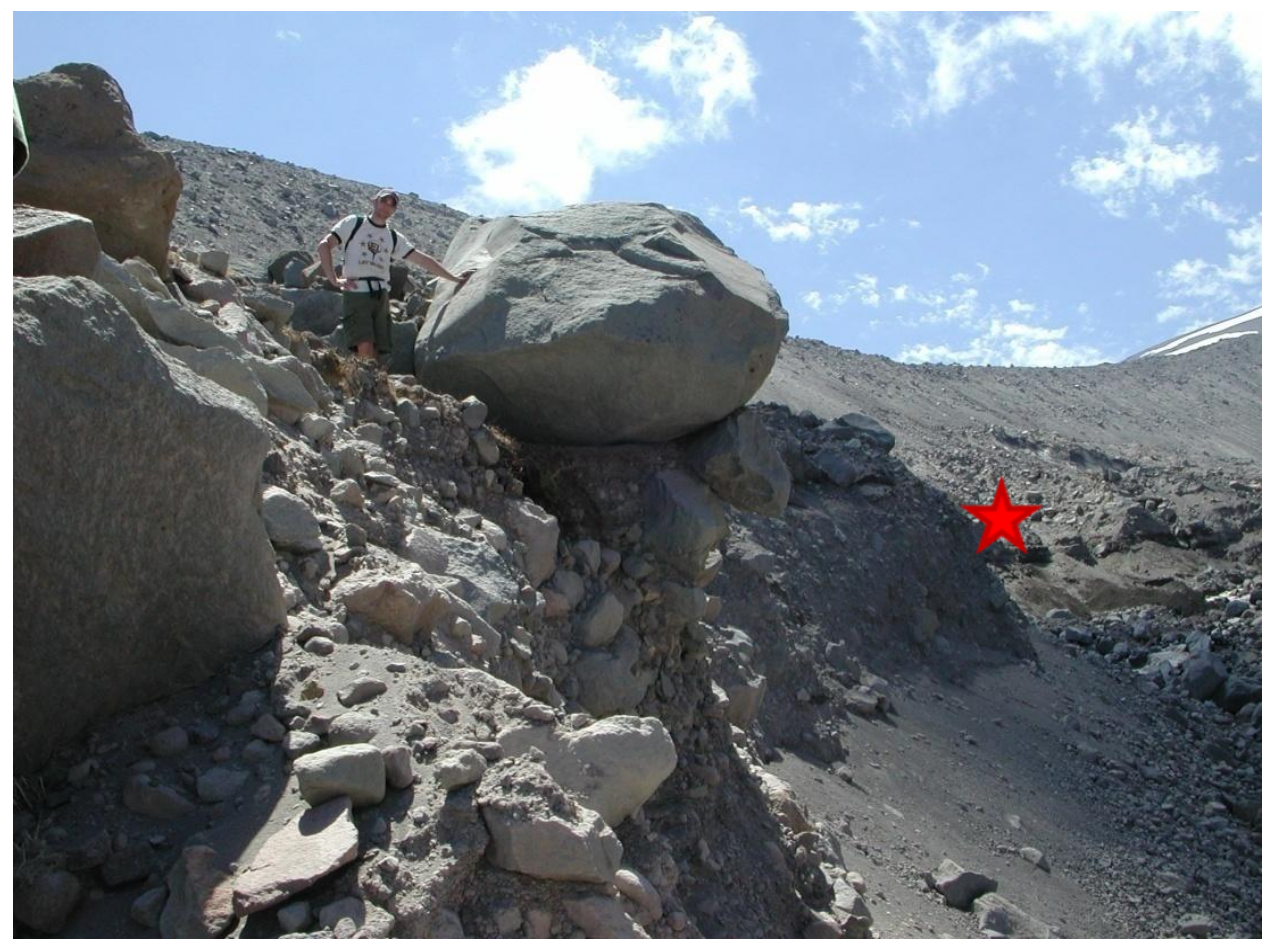

Figure 15. Eliot Creek sample collection site marked by red star (UTM 0604937N, 5028012E)

\section{Data Processing:}

\section{Sieve Results}

Six samples were collected from the initiation zone material just below the Eliot Glacier. The sieve results for all six samples are averaged and displayed in Table 2. Material from the Eliot Creek initiation zone has an average bulk density of $1.8 \mathrm{~g} / \mathrm{cm}^{3}$. The average sample is $40.5 \%$ gravel, $56.3 \%$ sand, and $2.9 \%$ fine grained material. At over $50 \%$ it is predominately sand but also contains a large amount of gravel. Fines on average make up less than $3 \%$ of the overall sample. Of the sand fraction, coarse grained sand is in the clear majority with almost $65 \%$. 
Table 2. Eliot Creek sieve results

\begin{tabular}{|c|c|c|c|c|c|c|c|}
\hline \multirow[b]{2}{*}{$\begin{array}{c}\text { Eliot Creek } \\
\text { Sample \# }\end{array}$} & \multirow{2}{*}{$\begin{array}{c}\text { Bulk } \\
\text { Density } \\
\left(\mathrm{g} / \mathrm{cm}^{3}\right)\end{array}$} & \multirow[b]{2}{*}{$\begin{array}{l}\text { Gravel } \\
>2 \mathrm{~mm}\end{array}$} & \multirow[b]{2}{*}{$\begin{array}{l}\text { Sand } \\
2 \mathrm{~mm}- \\
.063 \mathrm{~mm}\end{array}$} & \multirow{2}{*}{$\begin{array}{c}\text { Silt \& } \\
\text { Clay } \\
<.063 \mathrm{~mm}\end{array}$} & \multicolumn{3}{|c|}{ Sand } \\
\hline & & & & & $\begin{array}{c}\text { Coarse } \\
2 \mathrm{~mm}- \\
.25 \mathrm{~mm} \\
\end{array}$ & $\begin{array}{c}\text { Medium } \\
.25 \mathrm{~mm}- \\
.149 \mathrm{~mm} \\
\end{array}$ & $\begin{array}{l}\text { Fine } \\
.149 \mathrm{~mm}- \\
.063 \mathrm{~mm}\end{array}$ \\
\hline 1 & 1.6 & $46.1 \%$ & $51.7 \%$ & $1.9 \%$ & $63.7 \%$ & $19.6 \%$ & $16.7 \%$ \\
\hline 2 & 1.7 & $32.1 \%$ & $63.6 \%$ & $4.0 \%$ & $66.0 \%$ & $16.6 \%$ & $17.4 \%$ \\
\hline 3 & 1.6 & $33.8 \%$ & $63.3 \%$ & $2.4 \%$ & $62.2 \%$ & $21.9 \%$ & $15.9 \%$ \\
\hline 4 & 1.8 & $47.8 \%$ & $51.5 \%$ & $0.7 \%$ & $76.6 \%$ & $15.3 \%$ & $8.1 \%$ \\
\hline 5 & 2.1 & $36.6 \%$ & $59.3 \%$ & $3.8 \%$ & $62.2 \%$ & $18.4 \%$ & $19.4 \%$ \\
\hline 6 & 1.8 & $46.3 \%$ & $48.6 \%$ & $4.9 \%$ & $57.5 \%$ & $20.2 \%$ & $22.3 \%$ \\
\hline Average & 1.8 & $40.5 \%$ & $56.3 \%$ & $2.9 \%$ & $64.7 \%$ & $18.7 \%$ & $16.6 \%$ \\
\hline Standard dev. & $17 \%$ & $7 \%$ & $7 \%$ & $2 \%$ & $6 \%$ & $2 \%$ & $5 \%$ \\
\hline
\end{tabular}

\section{Drainage Basin Attributes}

The total basin catchment area for the Eliot Creek drainage is $8.7 \mathrm{~km}^{2}$ with an upper drainage basin area of $3.3 \mathrm{~km}^{2}$. The initiation zone is located between the elevations of $1,800 m-1,880 m$ and is $550 m$ from the Eliot Glacier, as mapped by Jackson, 2007, which has an area of approximately $1,640,000 \mathrm{~m}^{2}$. The Eliot Glacier is the largest glacier on Mount Hood. (Jackson, 2007). The upper drainage basin is $3.4 \%$ bedrock with $4.3 \%$ of the upper basin covered in vegetation. Steep unconsolidated and un-vegetated slopes account for $18.2 \%$ of the upper basin. Sediment type in the initiation zone is predominantly till of neo-glacial age (Qgnt) (Sherrod \& Scott, 1995) and received approximately $20 \mathrm{~cm}$ of rain in the November, 2006 storm which triggered the debris flows (NEXRAD, 2009). The overall azimuth of the upper drainage is $41^{\circ}$. The maximum elevation for the basin catchment area 
above the fan was calculated at 3,417 meters with a minimum elevation of 911

meters. Basin height above the fan is 2,506 meters. Stream gradient for the upper drainage basin is approximately 0.23 . Melton's Ruggedness number for this basin has been calculated at $\mathrm{R}=0.85$.

\section{SANDY RIVER DRAINAGE BASIN:}

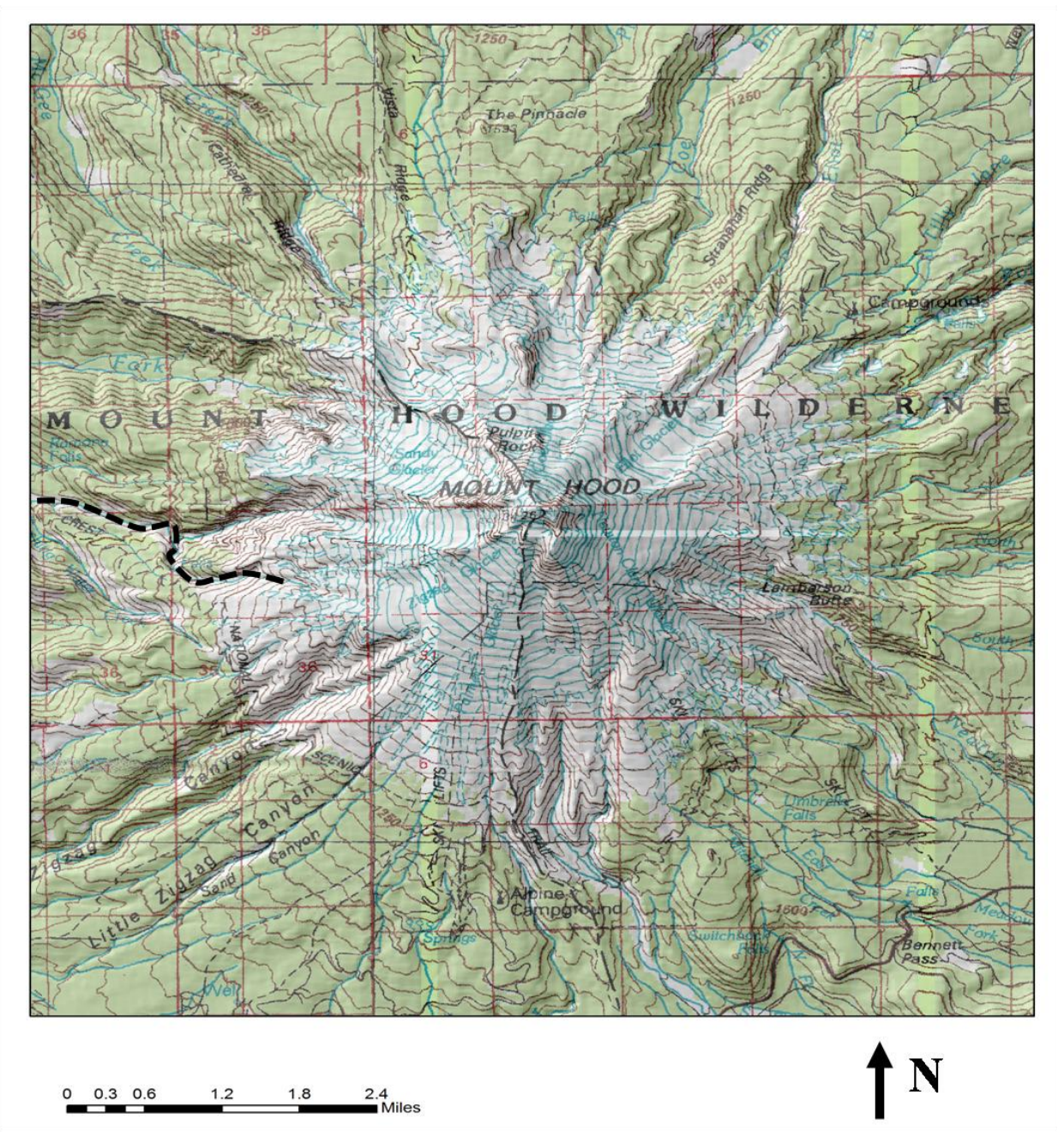

Figure 16. Sandy River shown in dashed black 
The south fork of the Sandy River is located on the west side of the mountain (Figure 16). The Sandy River drainage experienced a medium sized debris flow, travelling approximately $8 \mathrm{~km}$, as a result of the November, 2006 storm. The first evidence of debris flow occurrence came in the form of news reports from February $6^{\text {th }}$ indicating that the approach to a bridge crossing the Sandy River was washed out as of 2:22pm (KATU, 2006). The subsequent investigation into the Sandy Basin included a field based reconnaissance, sample collection and data processing.

\section{Reconnaissance \& Sample Collection:}

\section{Initial Reconnaissance:}

Evidence for debris flow activity was first noted where the Timberline Trail crosses the Sandy River. Unsorted, matrix supported debris filled the channel with woody debris on top forming log jams (Figure 17). Broken and splintered stumps are visible in some areas (Figure 18). Where the original ground surface contact with debris flow deposits is exposed, some green plants are visible (Figure 19). Steep slopes on canyon walls with no vegetation provide evidence of fresh erosion and scour. A lack of vegetation was noted in debris flow affected areas of the channel. Many small to medium sized slides were noted along the steep canyon walls (Figure 20). 


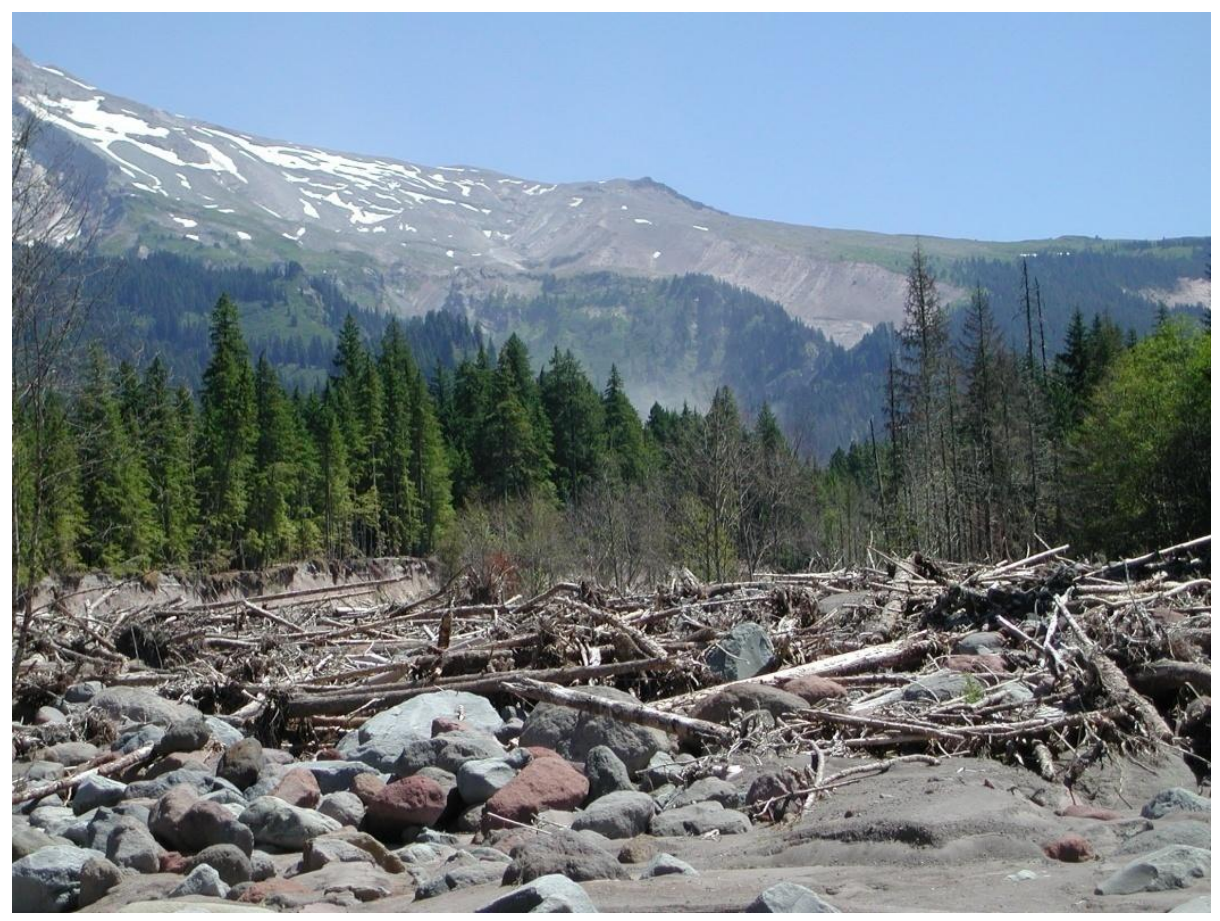

Figure 17. Sandy River log jam upstream from Timberline Trail crossing (looking east)

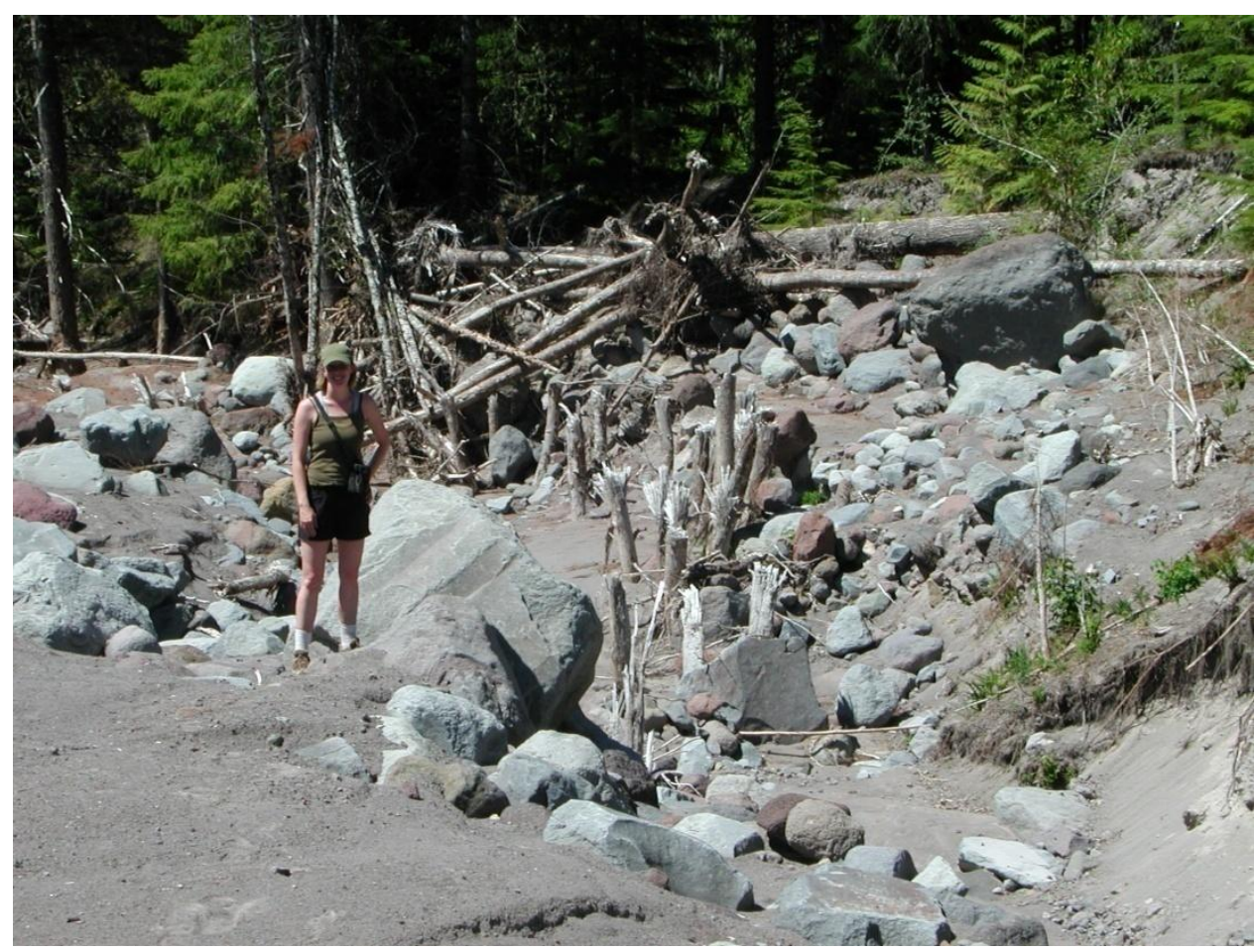

Figure 18. Sandy River splintered tree stumps near Timberline Trail crossing 


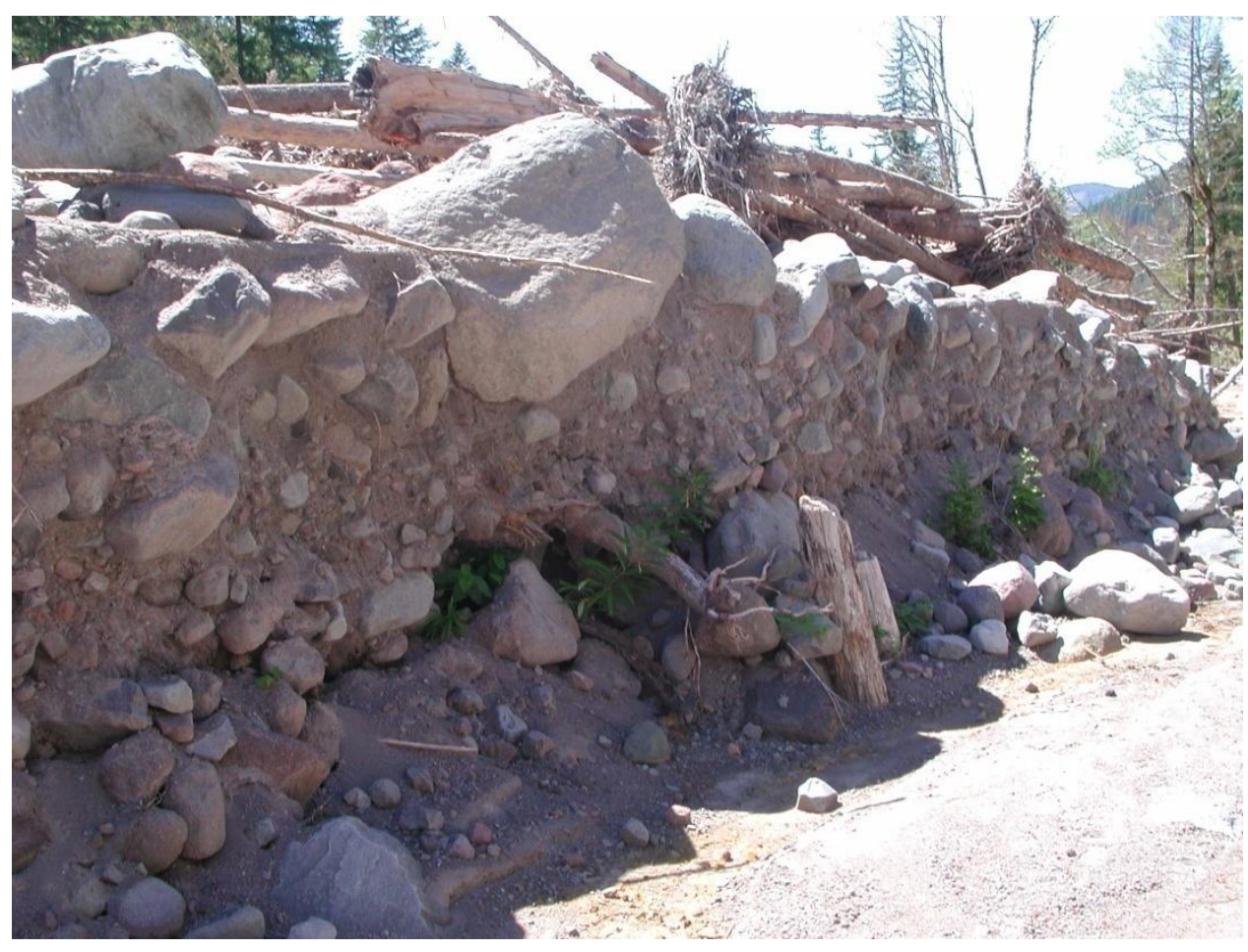

Figure 19. Sandy River debris flow deposit overlying vegetation of previous ground surface

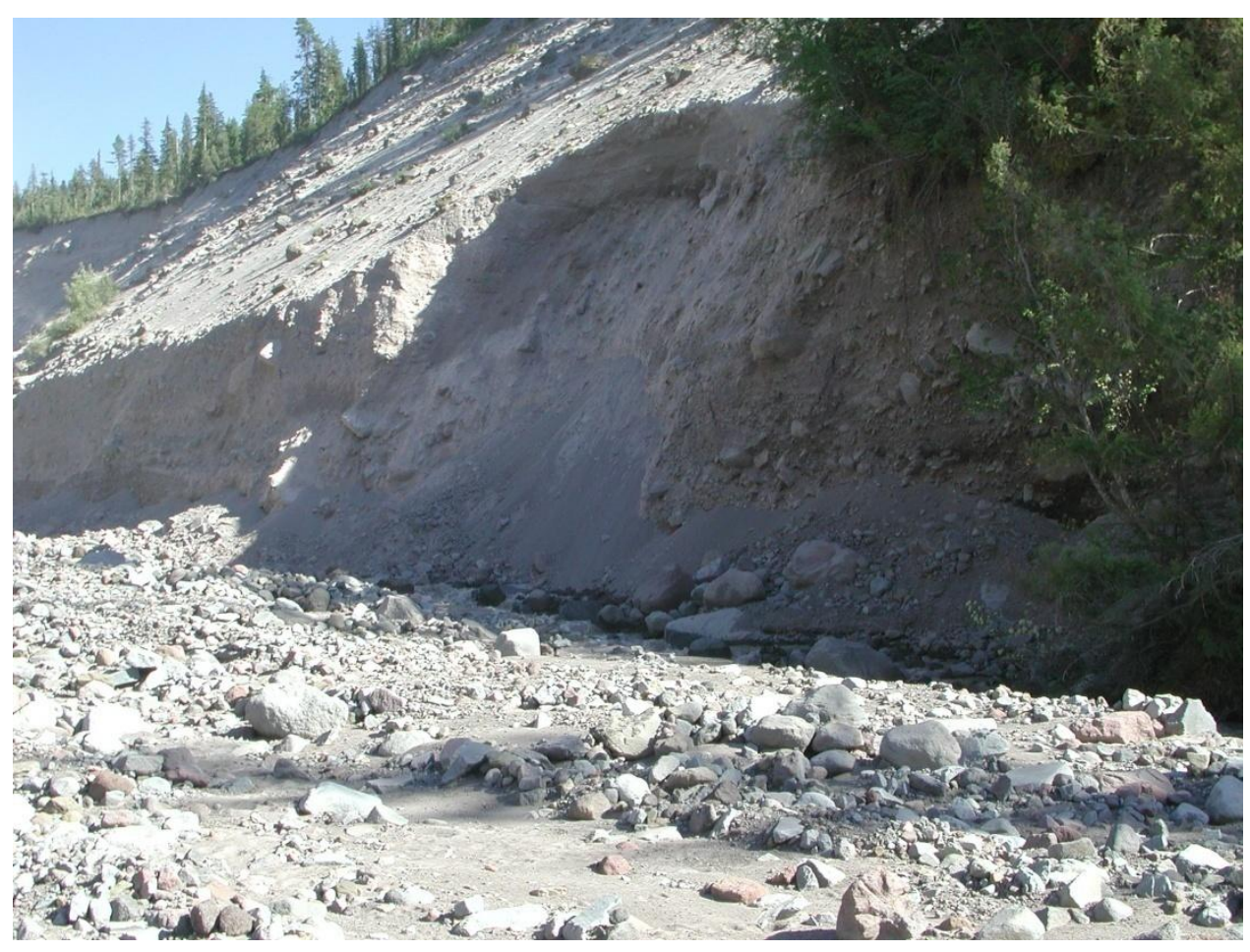

Figure 20. Landslide along steep canyon wall upstream from the Timberline Trail 


\section{Definition of Initiation Zone}

Two large landslides were observed in the northern sidewall material of the southern fork of the upper Sandy River. The Sandy River meandered into the scarp, actively undercutting the slope. The location is shown in (Figure 21). A debris trail consisting of outsized rocks and boulders strewn along the stream channel in a non fluvial pattern (Figure 22) is present below this point with boulder levees consistent with debris flow morphology (Pierson, 2005). While there is some evidence for erosion above the landslides, nothing that could contribute a significant amount of material was observed. The northern sidewall contains bedforms and ripple marks as evidence of the volcaniclastic fill deposit material. On the southern ridge in the

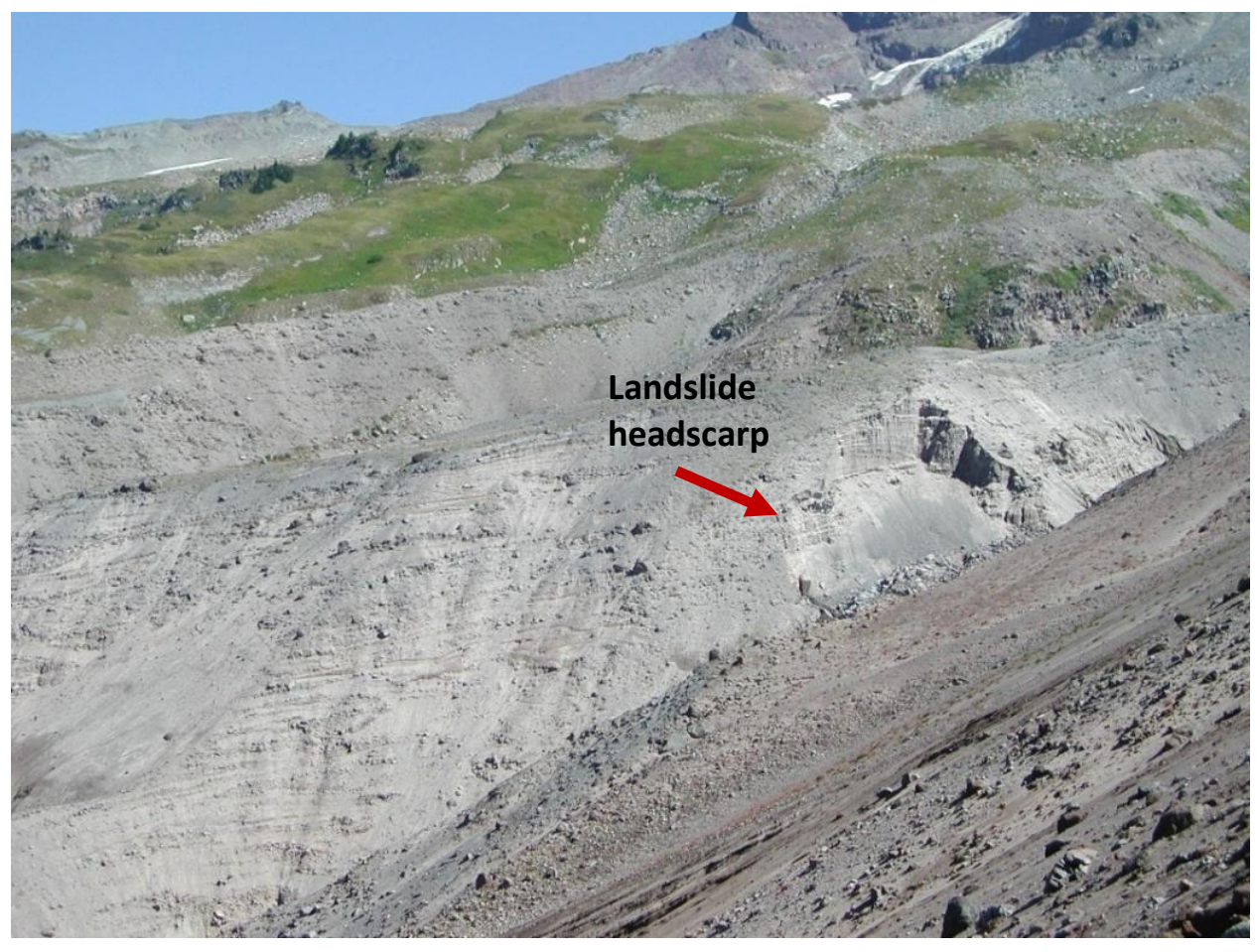

Figure 21. Sandy River initiation zone ( 271,000 $\mathrm{m}^{3}$ ) (UTM 0598770N, 5024282E) 
initiation zone the deposits appear unsorted, unconsolidated, and show no evidence of bedforms. Upstream from the landslides, bedrock in the channel was noted with steep unconsolidated material on the sidewalls.

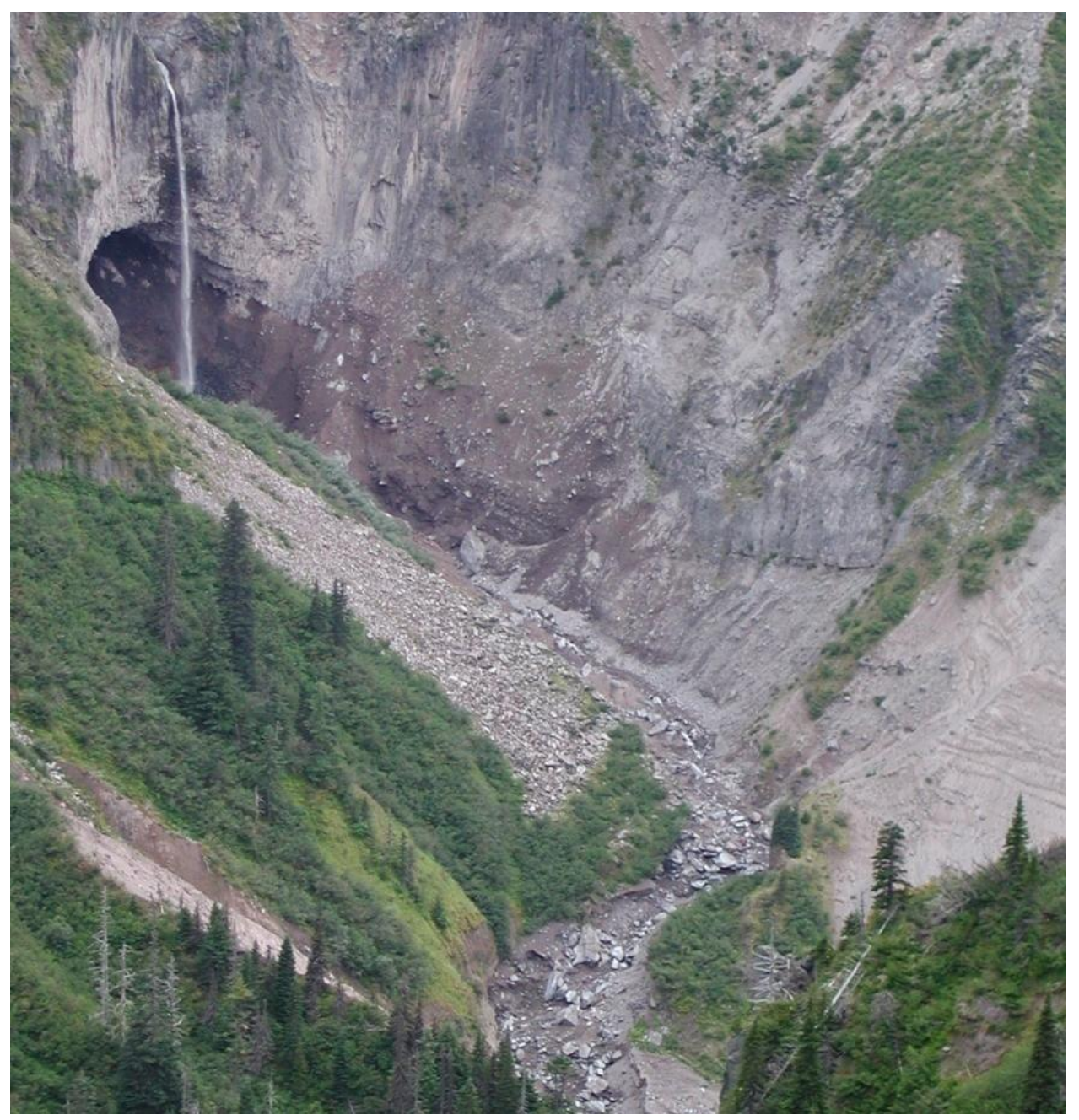

Figure 22. Sandy River debris trail downstream from initiation zone

\section{Sample Collection}

Six samples were collected from a canyon sidewall directly upstream from the initiation landslides. Samples were not collected from the scarp due to the extremely 
remote and rugged location; however, representative samples were collected from similar geologic material upstream. Figure 23 shows the location of sample collection.

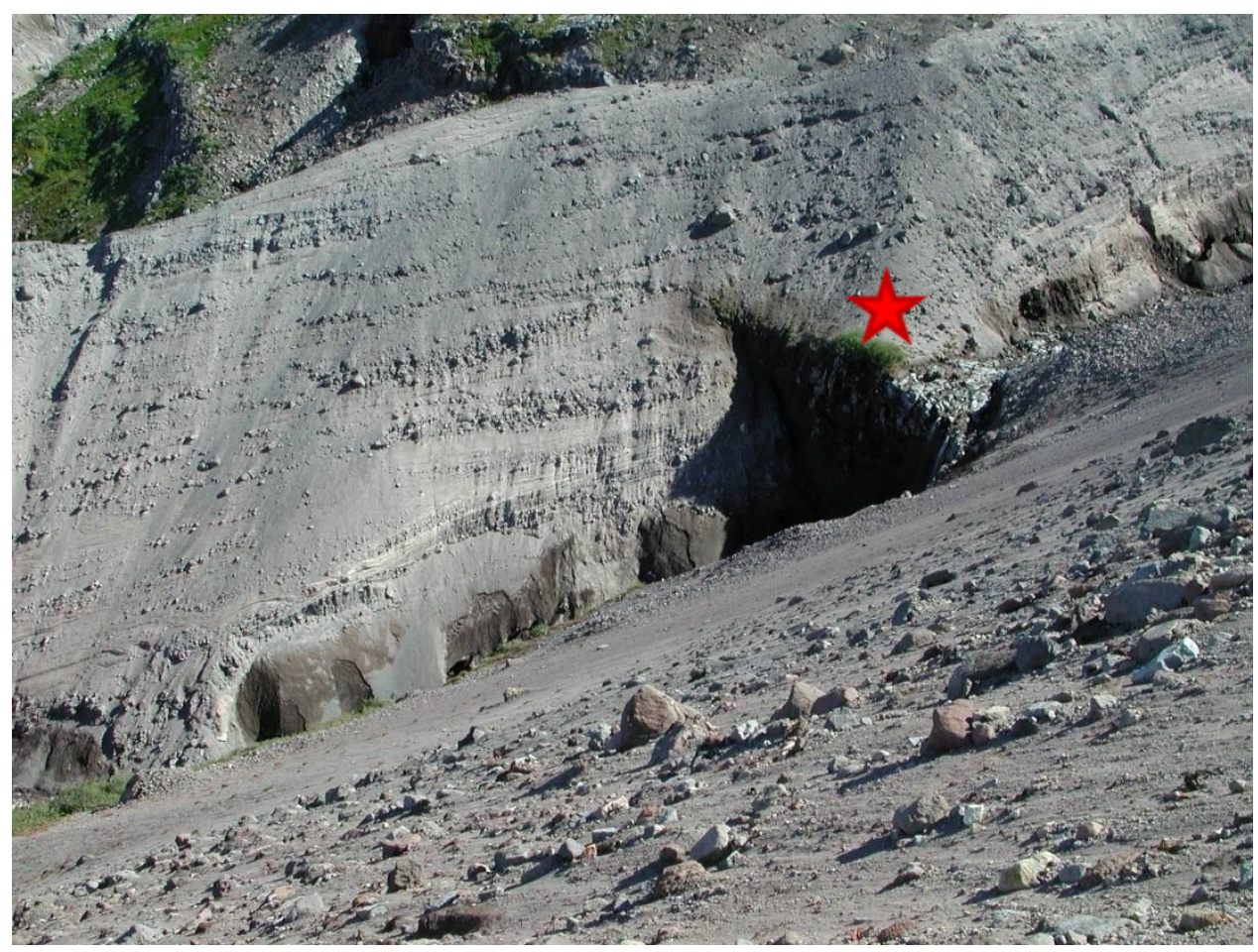

Figure 23. Sandy River sample collection site (UTM 0599149N, 5024071E)

\section{Data Processing:}

\section{Sieve Results}

Sieve results for the Sandy River Basin samples are averaged and shown in Table

3. Material from the Sandy River initiation zone has an average bulk density of 1.4 $\mathrm{g} / \mathrm{cm}^{3}$. The average sample is $15.3 \%$ gravel, $81.9 \%$ sand and $2.7 \%$ fines. Of the sand, coarse grained fraction is in the clear majority with $66 \%$. The low amount of gravel is characteristic of pyroclastic flow parent material. 
Table 3. Sandy River Sieve Results

\begin{tabular}{|c|c|c|c|c|c|c|c|}
\hline \multirow[b]{2}{*}{$\begin{array}{c}\text { Sandy River } \\
\text { Sample \# }\end{array}$} & \multirow{2}{*}{$\begin{array}{c}\text { Bulk } \\
\text { Density } \\
\left(\mathrm{g} / \mathrm{cm}^{3}\right)\end{array}$} & \multirow[b]{2}{*}{$\begin{array}{l}\text { Gravel } \\
>2 \mathrm{~mm}\end{array}$} & \multirow[b]{2}{*}{$\begin{array}{l}\text { Sand } \\
2 \mathrm{~mm}- \\
.063 \mathrm{~mm}\end{array}$} & \multirow{2}{*}{$\begin{array}{c}\text { Silt \& } \\
\text { Clay } \\
<.063 \mathrm{~mm}\end{array}$} & \multicolumn{3}{|c|}{ Sand } \\
\hline & & & & & $\begin{array}{c}\text { Coarse } \\
2 \mathrm{~mm}- \\
.25 \mathrm{~mm} \\
\end{array}$ & $\begin{array}{c}\text { Medium } \\
.25 \mathrm{~mm}- \\
.149 \mathrm{~mm} \\
\end{array}$ & $\begin{array}{c}\text { Fine } \\
.149 \mathrm{~mm}- \\
.063 \mathrm{~mm} \\
\end{array}$ \\
\hline 1 & 1.4 & $27.0 \%$ & $68.6 \%$ & $4.3 \%$ & $52.6 \%$ & $27.3 \%$ & $20.1 \%$ \\
\hline 2 & 1.6 & $6.9 \%$ & $89.4 \%$ & $3.5 \%$ & $60.7 \%$ & $24.2 \%$ & $15.0 \%$ \\
\hline 3 & 1.2 & $26.9 \%$ & $71.4 \%$ & $1.5 \%$ & $63.7 \%$ & $23.0 \%$ & $13.3 \%$ \\
\hline 4 & 1.3 & $3.6 \%$ & $95.0 \%$ & $1.3 \%$ & $84.7 \%$ & $10.2 \%$ & $5.1 \%$ \\
\hline 5 & 1.3 & $5.8 \%$ & $91.2 \%$ & $2.9 \%$ & $71.1 \%$ & $16.0 \%$ & $12.9 \%$ \\
\hline 6 & 1.4 & $21.7 \%$ & $75.8 \%$ & $2.6 \%$ & $63.0 \%$ & $21.9 \%$ & $15.1 \%$ \\
\hline Average & 1.4 & $15.3 \%$ & $81.9 \%$ & $2.7 \%$ & $66.0 \%$ & $20.4 \%$ & $13.6 \%$ \\
\hline Standard dev. & $14 \%$ & $11 \%$ & $11 \%$ & $1 \%$ & $11 \%$ & $6 \%$ & $5 \%$ \\
\hline
\end{tabular}

\section{Drainage Basin Attributes}

The total basin catchment area for the South Fork of the Sandy River drainage is $16.4 \mathrm{~km}^{2}$ with an upper drainage basin area of $3.1 \mathrm{~km}^{2}$. The initiation zone is located between the elevations of 1,860 and 1,790 meters and is approximately 1,770 meters from the Zigzag Glacier which has an area of approximately $769,000 \mathrm{~m}^{2}$. The upper drainage basin is $5 \%$ bedrock with $7.5 \%$ of the upper basin covered in vegetation. Steep unconsolidated and un-vegetated slopes account for $29.5 \%$ of the upper basin. Sediment type in the initiation zone is predominantly pyroclastic and received approximately $36 \mathrm{~cm}$ of rain in the November, 2006 storm which triggered the debris flows. The overall azimuth of the upper drainage is $260^{\circ}$. The maximum elevation for the basin catchment area above the fan was calculated at 3,417 meters with a minimum of 1,637 meters. The basin height above the fan is 1,780 meters. Stream 
gradient for the upper drainage basin is .27. Melton's Ruggedness number for this basin has been calculated at $R=0.44$.

\section{WHITE RIVER DRAINAGE BASIN:}

The White River is located on the south side of the mountain (Figure 24). The White River drainage experienced a medium sized debris flow, based on a travel distance of approximately $8 \mathrm{~km}$, as a result of the November, 2006 storm.

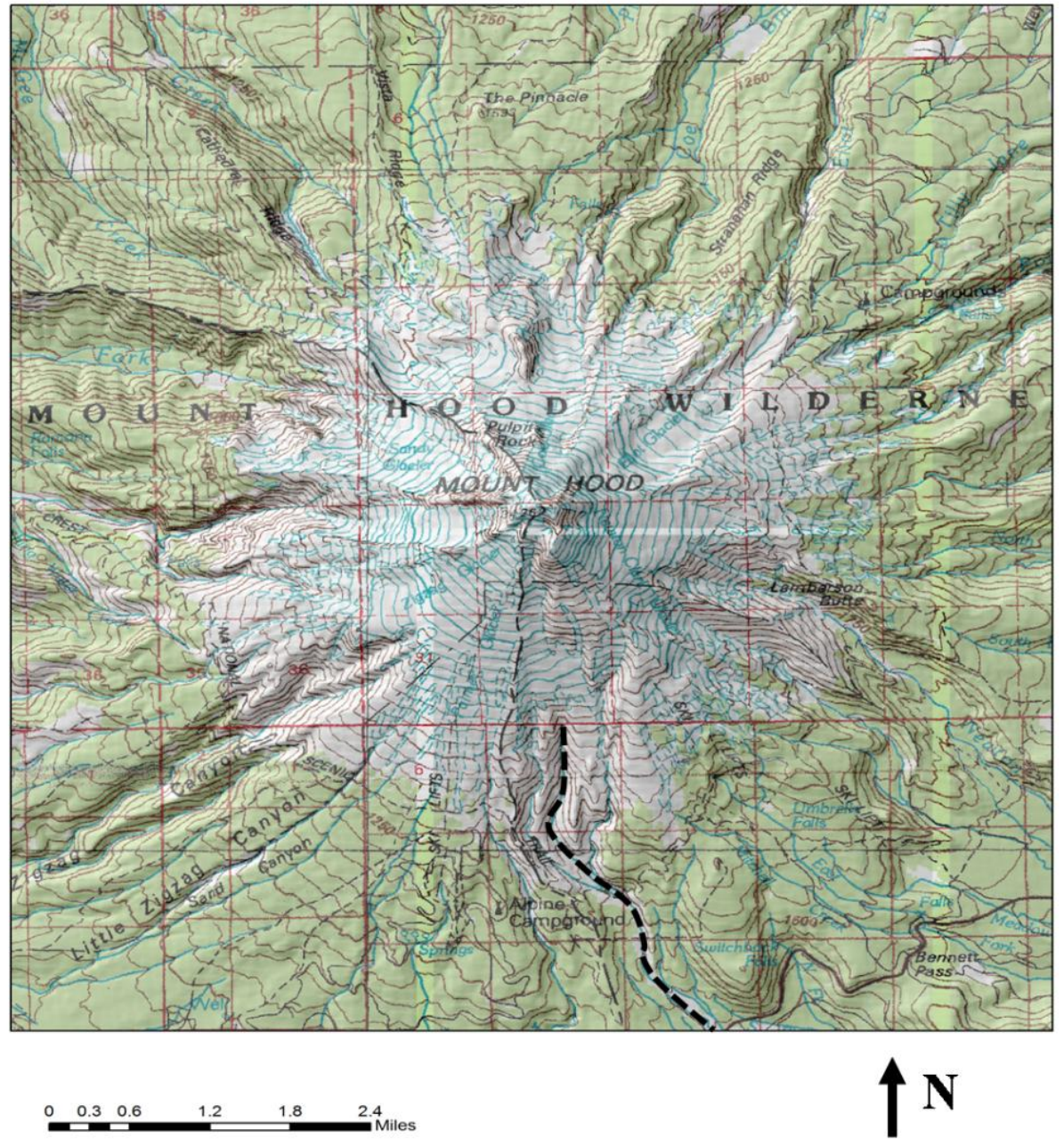

Figure 24. White River is shown in dashed black 
This debris flow caused some of the most extensive damage due to the close proximity of Highway 35. An estimated 1.5 million cubic meters of material was removed by Oregon Department of Transportation due to this event (ODOT, 2006). The first evidence of debris flow occurrence came in the form of news reports from February $6^{\text {th }}$ indicating that Highway 35 was closed as of 2:22pm (KATU, 2006). The subsequent investigation into the White Basin included a field based reconnaissance, sample collection and data processing.

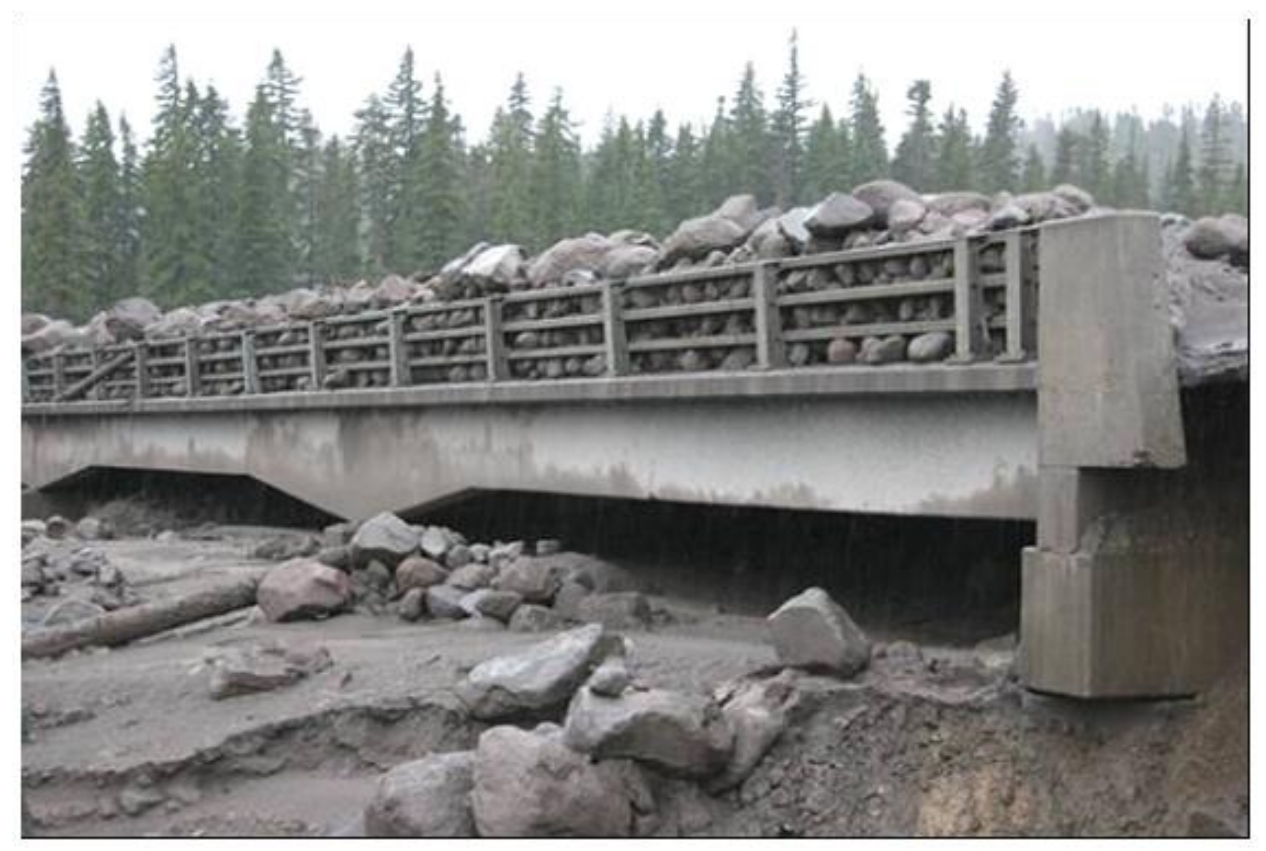

Figure 25. White River Bridge covered by debris flow deposit (ODOT photo)

\section{Reconnaissance \& Sample Collection:}

\section{Initial Reconnaissance}

Evidence of debris flow activity was apparent at the Highway 35 crossing of the White River. Photos from the event taken by the Oregon Department of 
Transportation show the White River Bridge covered by boulders and in filled by an unsorted, matrix supported debris deposit as shown in Figure 25.

Other evidence of debris flow activity includes a distinct lack of vegetation in impacted areas and levees present with some fine grained sand layers (Figure 26) representative of lower energy pulses within the debris flow (Tom Pierson, personal communication, 2007). Also observed were fresh channels dug by rerouting of the river and significant erosion and scour upstream from the Highway 35 crossing. Twisted metal and debris was also present from the destruction of portions of a guardrail and culvert near the highway.

\section{Definition of Initiation Zone}

The White River does not have a discrete initiation zone such as a landslide. The debris flow deposits and levees morph into a debris trail which disappears under residual glacier ice as one moves up the valley. Therefore, this drainage debris flow is classified as a "headless" debris flow. The initiation zone is defined as the area at the beginning of large scale debris flow features such as boulder levees and debris flow scour.

\section{Sample Collection}

Samples were collected downstream from the initiation zone from what can be considered to be the same geologic material type as shown in Figure 27 . This 


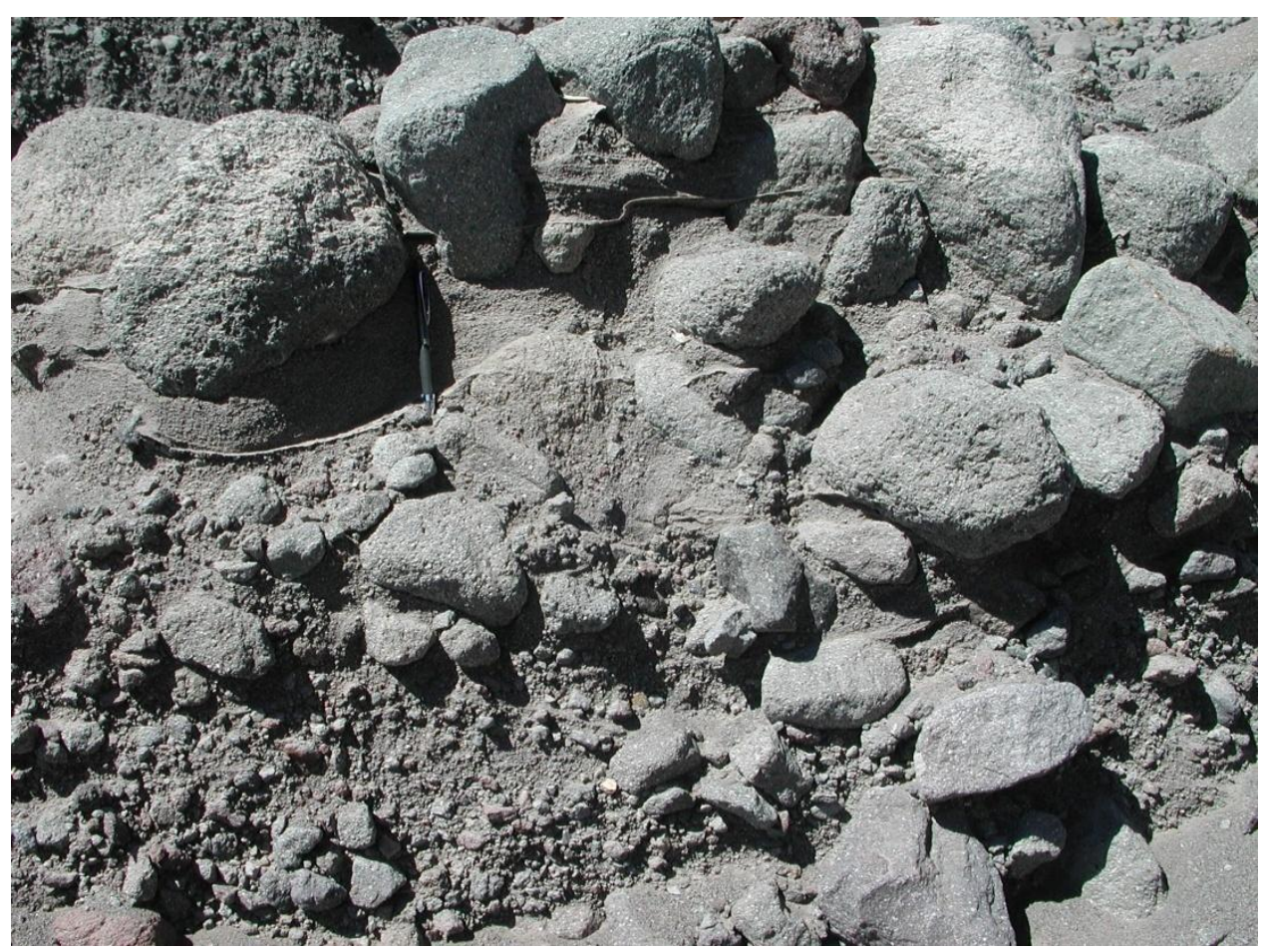

Figure 26. Fine grained layers in debris flow levees upstream from the Timberline Trail

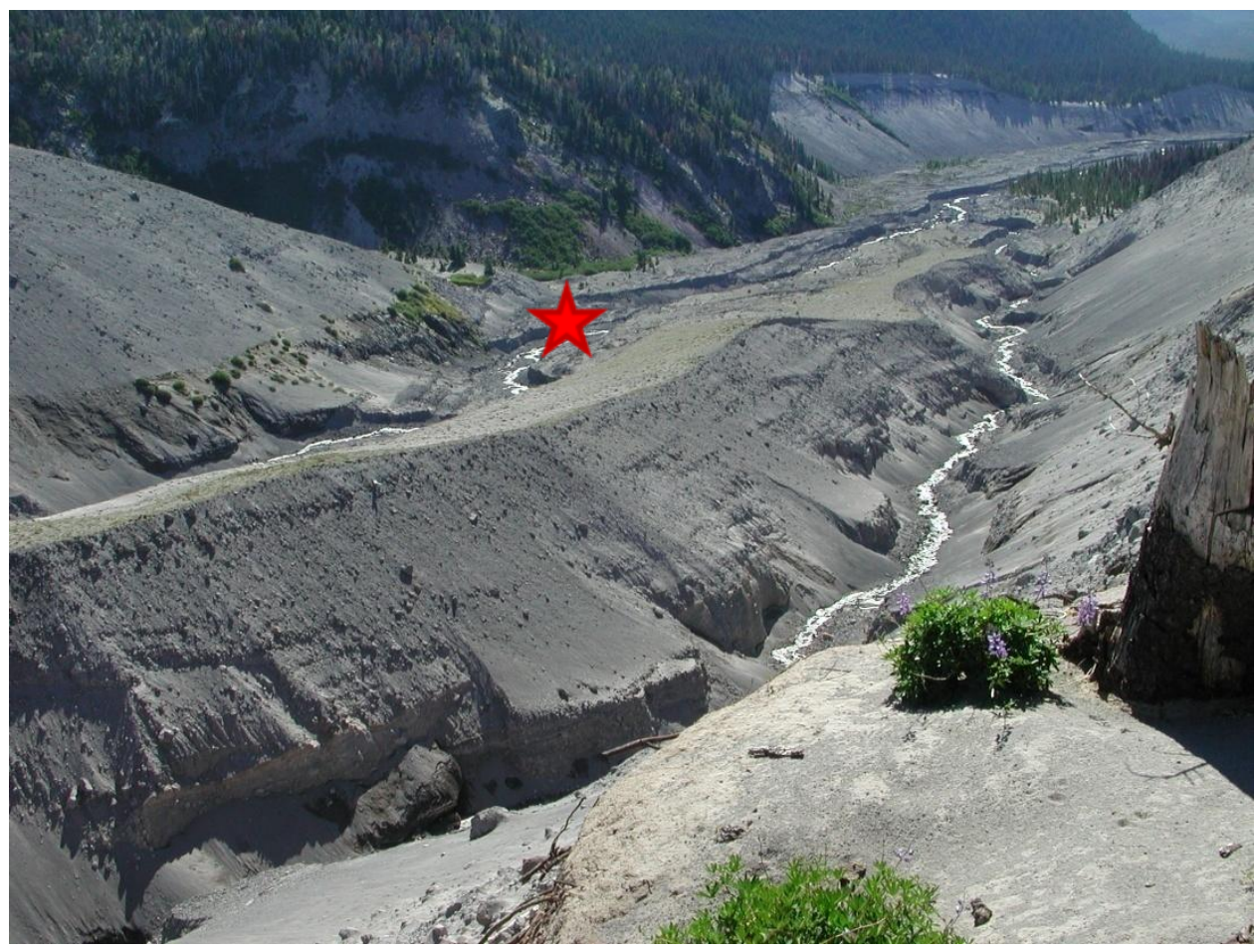

Figure 27. White River sample collection site (UTM 0602484N, 5019919E) 
assumption is based on both the geologic map of Mount Hood (Sherrod \& Scott, 1995) and from field based visual assessments.

\section{Data Processing:}

\section{Sieve Results}

Samples collected from the White River are averaged and displayed below in Table 4. Material from the White River initiation zone equivalent has an average bulk density of $1.8 \mathrm{~g} / \mathrm{cm}^{3}$. The average sample is $29.3 \%$ gravel, $67.7 \%$ sand, and $2.8 \%$ fine grained material. Of the sand, coarse grained material is in the clear majority with almost $75 \%$. .

Table 4. White River sieve results

\begin{tabular}{|c|c|c|c|c|c|c|c|}
\hline \multirow[b]{2}{*}{$\begin{array}{c}\text { White River } \\
\text { Sample \# }\end{array}$} & \multirow{2}{*}{$\begin{array}{c}\text { Bulk } \\
\text { Density } \\
\left(\mathrm{g} / \mathrm{cm}^{3}\right)\end{array}$} & \multirow[b]{2}{*}{$\begin{array}{l}\text { Gravel } \\
>2 \mathrm{~mm}\end{array}$} & \multirow[b]{2}{*}{$\begin{array}{l}\text { Sand } \\
2 \mathrm{~mm}- \\
.063 \mathrm{~mm}\end{array}$} & \multirow[b]{2}{*}{$\begin{array}{c}\text { Silt \& } \\
\text { Clay } \\
<.063 \mathrm{~mm}\end{array}$} & \multicolumn{3}{|c|}{ Sand } \\
\hline & & & & & $\begin{array}{c}\text { Coarse } \\
2 \mathrm{~mm}- \\
.25 \mathrm{~mm} \\
\end{array}$ & $\begin{array}{c}\text { Medium } \\
.25 \mathrm{~mm}- \\
.149 \mathrm{~mm} \\
\end{array}$ & $\begin{array}{c}\text { Fine } \\
.149 \mathrm{~mm}- \\
.063 \mathrm{~mm} \\
\end{array}$ \\
\hline 1 & 1.7 & $8.4 \%$ & $86.5 \%$ & $4.9 \%$ & $69.4 \%$ & $16.8 \%$ & $13.8 \%$ \\
\hline 2 & 1.7 & $22.8 \%$ & $74.3 \%$ & $2.7 \%$ & $74.1 \%$ & $14.2 \%$ & $11.6 \%$ \\
\hline 3 & 1.8 & $29.5 \%$ & $67.1 \%$ & $3.2 \%$ & $74.7 \%$ & $13.3 \%$ & $8.0 \%$ \\
\hline 4 & 1.8 & $46.0 \%$ & $51.9 \%$ & $2.0 \%$ & $73.5 \%$ & $13.5 \%$ & $13.0 \%$ \\
\hline 5 & 2.0 & $41.9 \%$ & $56.1 \%$ & $1.9 \%$ & $74.4 \%$ & $15.5 \%$ & $10.1 \%$ \\
\hline 6 & 1.7 & $27.3 \%$ & $70.4 \%$ & $2.2 \%$ & $80.9 \%$ & $10.9 \%$ & $8.2 \%$ \\
\hline Average & 1.8 & $29.3 \%$ & $67.7 \%$ & $2.8 \%$ & $74.5 \%$ & $14.0 \%$ & $10.8 \%$ \\
\hline Standard dev. & $14 \%$ & $14 \%$ & $13 \%$ & $1 \%$ & $4 \%$ & $2 \%$ & $2 \%$ \\
\hline
\end{tabular}

\section{Drainage Basin Attributes}

The total basin catchment area for the White River is $12.0 \mathrm{~km}^{2}$ with an upper drainage basin area of $6.5 \mathrm{~km}^{2}$. The initiation zone is located near elevation 2,141 meters and is approximately 610 meters from the White Glacier which has an area of 
approximately $407,000 \mathrm{~m}^{2}$. The upper drainage basin is $2.5 \%$ bedrock with $2.0 \%$ of the upper basin covered in vegetation. Steep unconsolidated and unvegetated slopes account for $41.5 \%$ of the upper basin. Sediment type in the initiation zone is predominantly pyroclastic valley infill and received approximately 15 to $20 \mathrm{~cm}$ of rain in the November, 2006 storm which triggered the debris flows (NEXRAD, 2009). The overall azimuth of the upper drainage is $175^{\circ}$. The max elevation for the basin catchment area above the fan was calculated at 3,418 meters with a minimum of 1,500 meters. The basin height is 1,918 meters. Stream gradient for the upper drainage basin is approximately .18. Melton's Ruggedness number for this basin has been calculated at $\mathrm{R}=0.75$.

\section{NEWTON CREEK DRAINAGE BASIN:}

Newton Creek is located on the south east side of the mountain (Figure 28). The Newton Creek Drainage experienced one of the largest debris flows, approximately $12 \mathrm{~km}$, as a result of the November, 2006 storm. The first evidence of debris flow occurrence came in the form of news reports from February $6^{\text {th }}$ indicating that Highway 35 was closed as of 2:22pm (KATU, 2006). The subsequent investigation into the Newton Creek Basin included a field based reconnaissance, sample collection and data processing. 


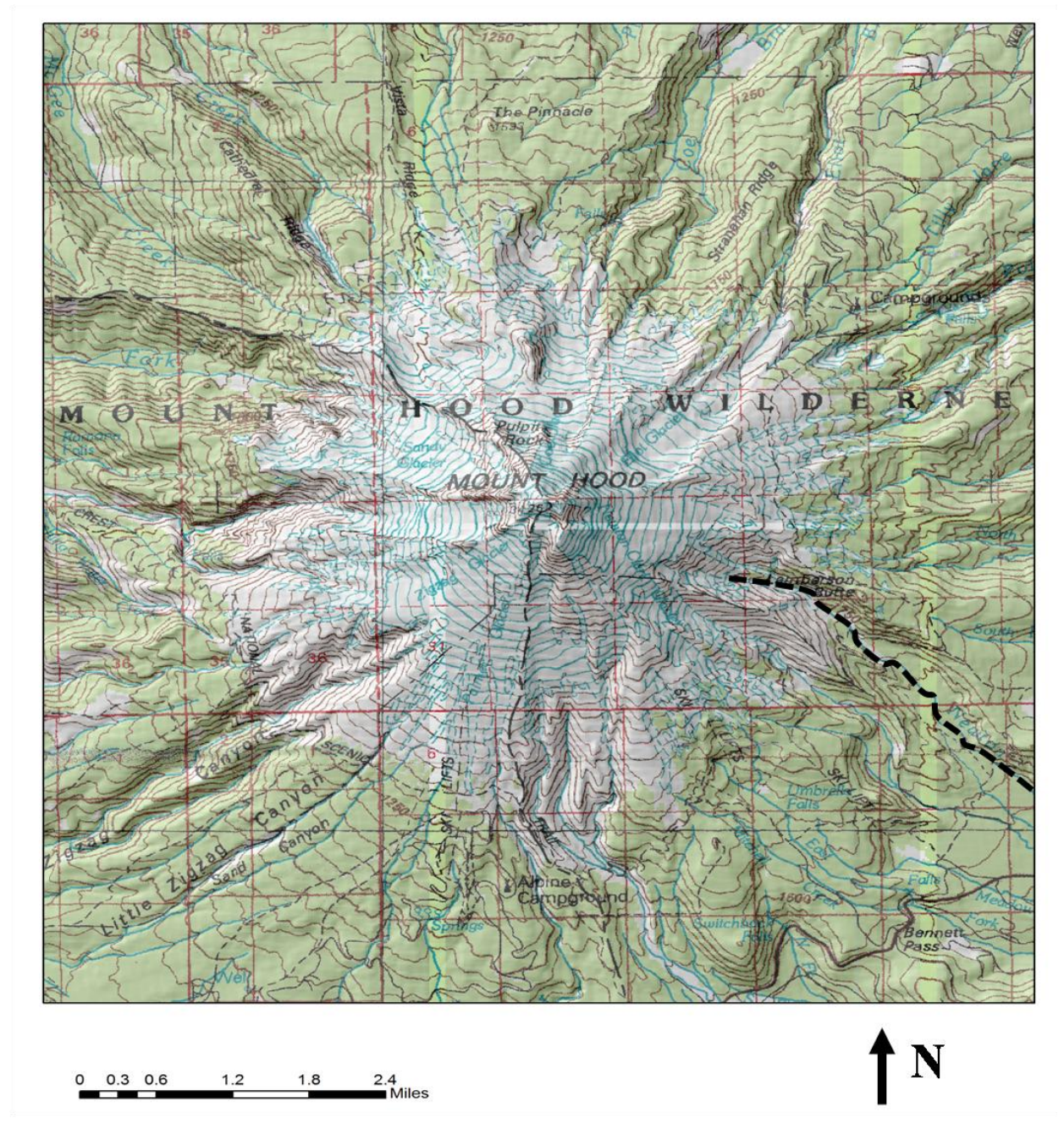

Figure 28. Newton Creek shown in dashed black

\section{Reconnaissance \& Sample Collection:}

\section{Initial Reconnaissance}

The presence of boulder levees, log jams, large boulders and matrix supported debris deposits were noted near the old crossing of Highway 35 \& Newton Creek (Figure 29). Photos taken by the Oregon Department of Transportation directly after the event showed that the highway had been ripped apart where Newton Creek previously crossed under it (Figure 30). Upstream from the highway, a distinct lack 
of vegetation was noted in the active channel and scouring was present on the canyon side-walls.

\section{Definition of Initiation Zone}

Debris flow characteristics including boulder levees, a lack of vegetation in or near the channel, and abundant fresh erosion were noted continuously upstream. Just below the glacier the headwaters of Newton Creek flows across some very steep unconsolidated and unvegetated slopes. A portion of these steep slopes is the result of an ancient landslide (Tom Pierson, Personal Communication, 2007). These steep slopes did not show evidence of recent landsliding. However, large past slides that had caused previous debris flows (DeRoo, 2009) were visible in the headwaters. Fresh debris tracks and trails were present across the slopes (Figure 31). A light gray color indicated that the debris tracks were fresher than the surrounding material. It was observed that they coalesced together in the main body of the channel's upper reaches. Directly downstream from the upper reaches, large scale evidence of debris flow activity including heavy scour and absence of vegetation in or near the channel was observed. This is another example of a headless debris flow. 


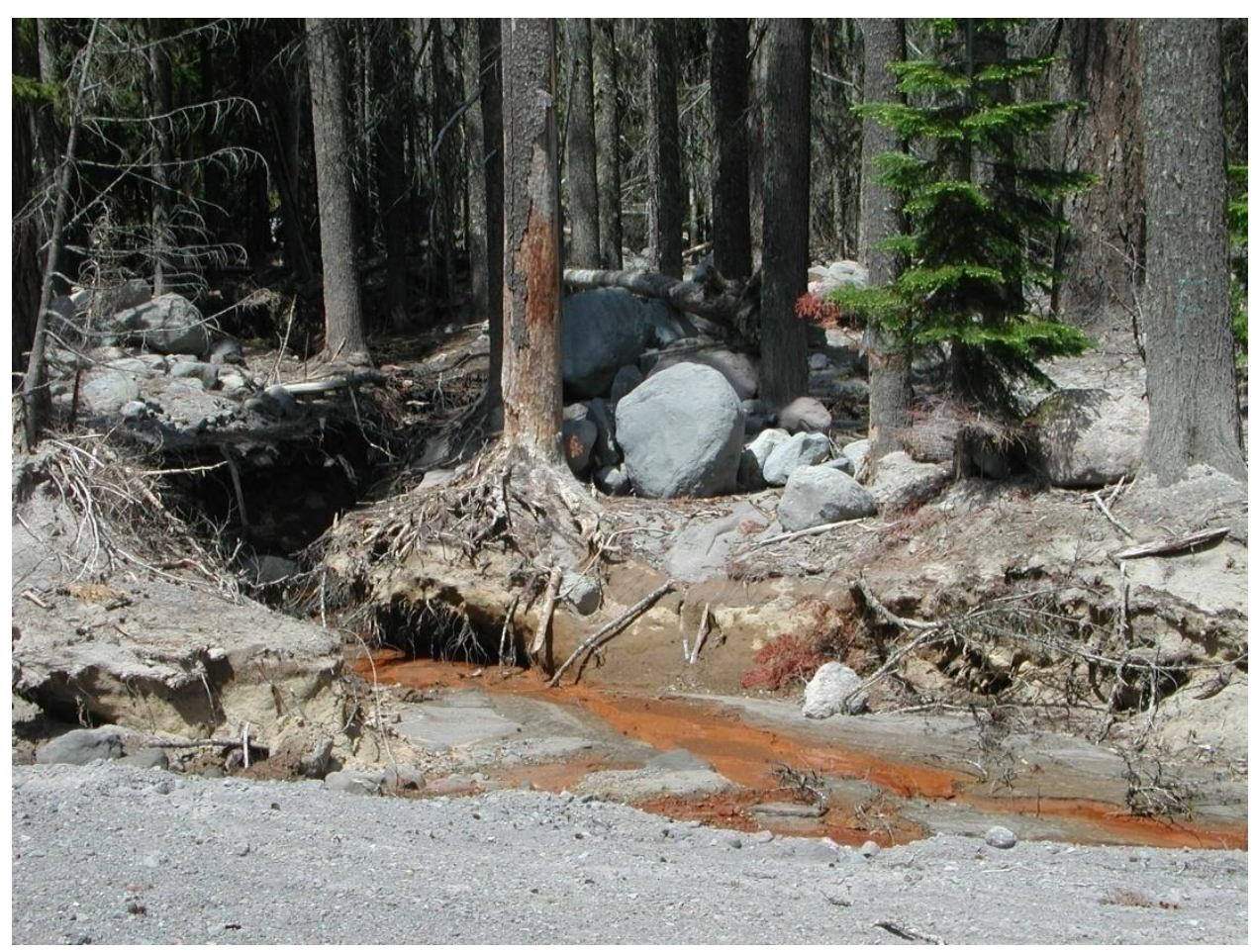

Figure 29. Newton Creek at Highway 35 crossing

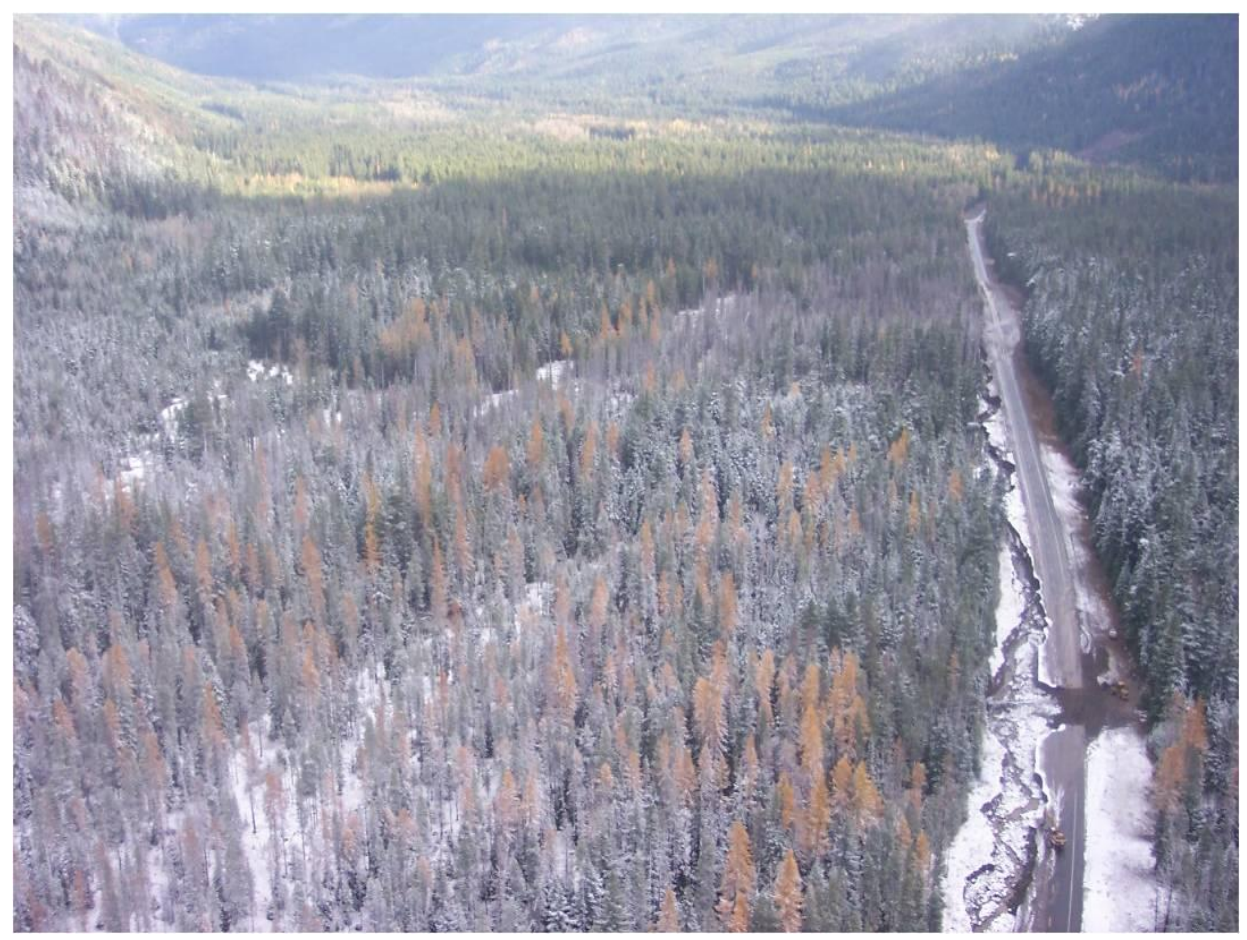

Figure 30. Highway 35 damage east of Hood River Bridge (photo courtesy of ODOT) 


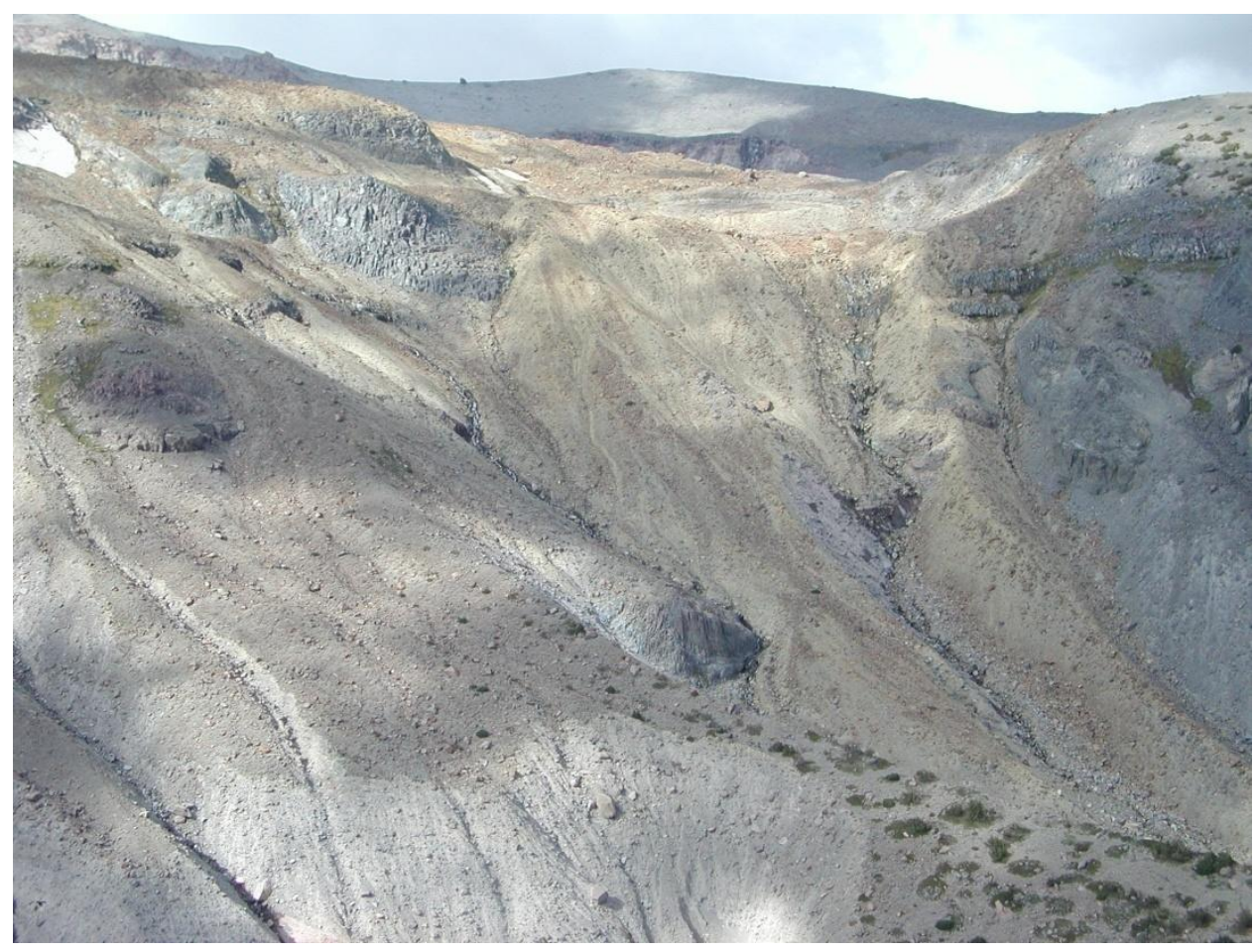

Figure 31. Newton Creek initiation zone

\section{Sample Collection}

Six soil samples were collected from the downstream landslide deposit of an ancient landslide (Figure 32). This landslide deposit was determined to be representative of the typical geologic material from the initiation zone as it is known to have originated from the same upstream landslide source as described by Tom Pierson (personal communication, 2007).

\section{Data Processing:}

\section{Sieve Results}

Sieve results for Newton Creek are averaged and displayed in Table 5. Material from the Newton Creek initiation zone equivalent has an average bulk density of 1.6 
$\mathrm{g} / \mathrm{cm}^{3}$. The average sample is $17 \%$ gravel, $77.6 \%$ sand, and $5.4 \%$ fine grained

material. Of the sand, coarse grained material is in the clear majority with almost $66 \%$.

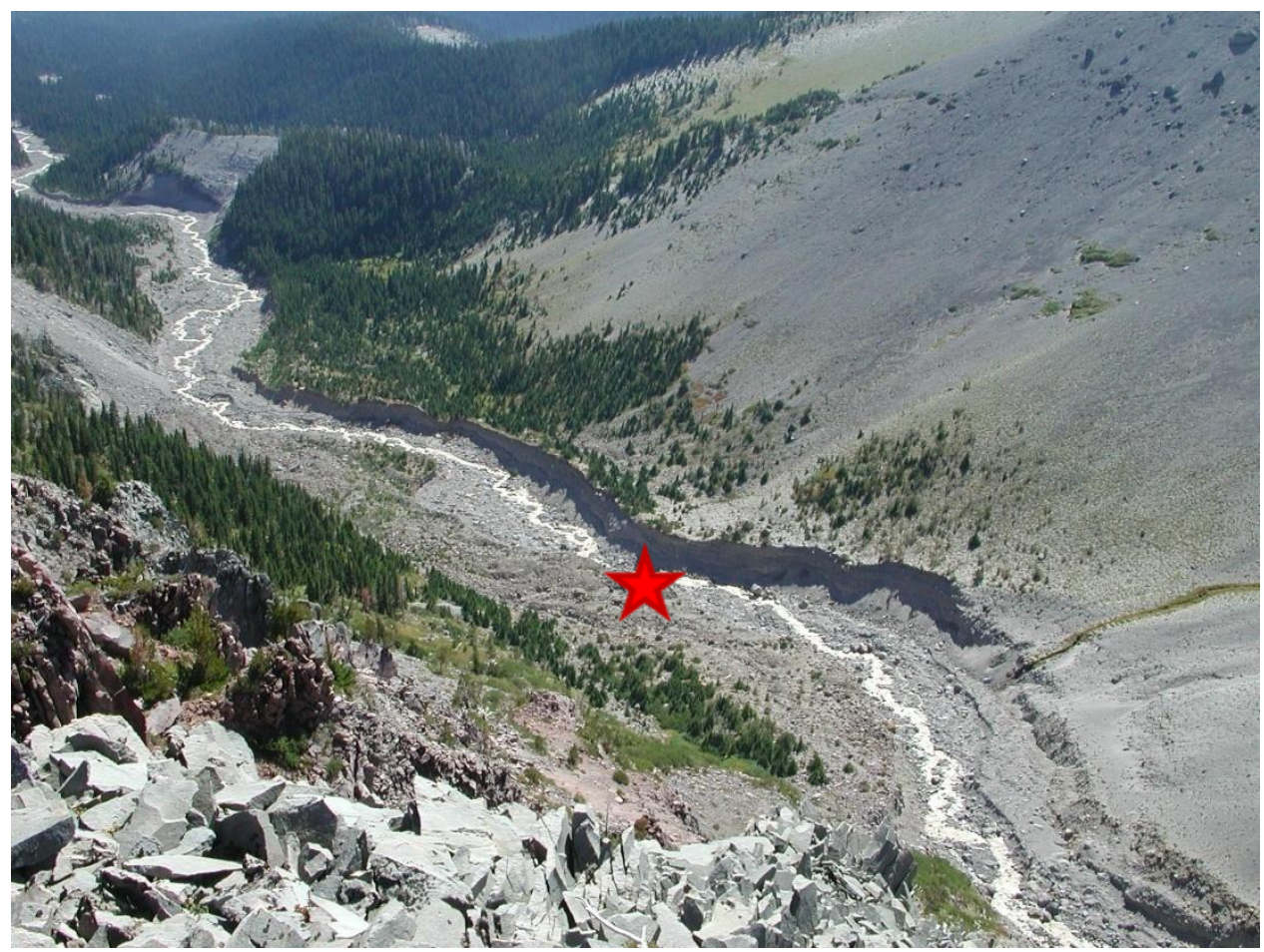

Figure 32. Newton Creek sample collection location (UTM 0605698N, 5023493E)

Table 5. Newton Creek sieve results

\begin{tabular}{|c|r|r|r|r|r|r|r|}
\hline $\begin{array}{c}\text { Newton } \\
\text { Creek } \\
\text { Sample \# }\end{array}$ & $\begin{array}{c}\text { Bulk } \\
\text { Density } \\
\left(\mathbf{g} / \mathbf{c m}^{\mathbf{3}} \mathbf{)}\right.\end{array}$ & $\begin{array}{c}\text { Gravel } \\
>2 \mathrm{~mm}\end{array}$ & $\begin{array}{c}\text { Sand } \\
2 \mathrm{~mm}- \\
.063 \mathrm{~mm}\end{array}$ & $\begin{array}{c}\text { Silt \& } \\
\text { Clay } \\
<.063 \mathrm{~mm}\end{array}$ & $\begin{array}{c}\text { Coarse } \\
2 \mathrm{~mm}-\end{array}$ & $\begin{array}{c}\text { Medium } \\
.25 \mathrm{~mm}-\end{array}$ & $\begin{array}{c}\text { Fine } \\
.149 \mathrm{~mm}-\end{array}$ \\
\hline $\mathbf{1}$ & 1.9 & $18.6 \%$ & $76.9 \%$ & $4.5 \%$ & $63.7 \%$ & $19.4 \%$ & $16.9 \%$ \\
$\mathbf{2}$ & 1.7 & $15.0 \%$ & $80.6 \%$ & $4.5 \%$ & $71.2 \%$ & $16.0 \%$ & $12.8 \%$ \\
$\mathbf{3}$ & 1.6 & $13.1 \%$ & $80.1 \%$ & $6.6 \%$ & $68.0 \%$ & $16.4 \%$ & $15.6 \%$ \\
$\mathbf{4}$ & 1.6 & $15.6 \%$ & $77.7 \%$ & $6.3 \%$ & $63.5 \%$ & $19.2 \%$ & $17.4 \%$ \\
$\mathbf{5}$ & 1.6 & $24.1 \%$ & $70.9 \%$ & $4.8 \%$ & $65.8 \%$ & $18.8 \%$ & $15.5 \%$ \\
$\mathbf{6}$ & 1.4 & $15.6 \%$ & $79.3 \%$ & $5.7 \%$ & $62.6 \%$ & $20.0 \%$ & $17.4 \%$ \\
\hline Average & 1.6 & $17.0 \%$ & $77.6 \%$ & $5.4 \%$ & $65.8 \%$ & $18.3 \%$ & $15.9 \%$ \\
\hline Standard dev. & $14 \%$ & $4 \%$ & $4 \%$ & $1 \%$ & $3 \%$ & $2 \%$ & $2 \%$ \\
\hline
\end{tabular}




\section{Drainage Basin Attributes}

The total basin catchment area for the Newton Creek is $8.0 \mathrm{~km}^{2}$ with an upper drainage basin area of $5.3 \mathrm{~km}^{2}$. The initiation zone for the headless debris flow is a hillslope covered by rills and located between the elevations of 1,810 and 2,170 meters. It is 790 meters from the Newton-Clark Glacier which has an area of approximately $1,390,000 \mathrm{~m}^{2}$. Steep unconsolidated and unvegetated slopes account for $23 \%$ of the upper basin. Sediment type in the initiation zone is predominantly neoglacial till and landslide material originating from the till and received approximately $15 \mathrm{~cm}$ of rain in the November, 2006 storm which triggered the debris flows (NEXRAD, 2009). The overall azimuth of the upper drainage is $122^{\circ}$. The maximum elevation for the basin catchment area above the fan was calculated at 3,419 meters with a minimum of 1,390 meters. The basin height is 2,029 meters. Stream gradient for the upper drainage basin is approximately .15. Melton's Ruggedness number for this basin has been calculated at $\mathrm{R}=0.72$.

\section{CLARK CREEK DRAINAGE BASIN:}

Clark Creek is located on the south east side of the mountain as shown in Figure 27. The Clark Creek Drainage experienced a small debris flow, travelling approximately $3 \mathrm{~km}$, as a result of the November, 2006 storm. The investigation into the Clark Creek Basin included a field based reconnaissance, sample collection and data processing. 


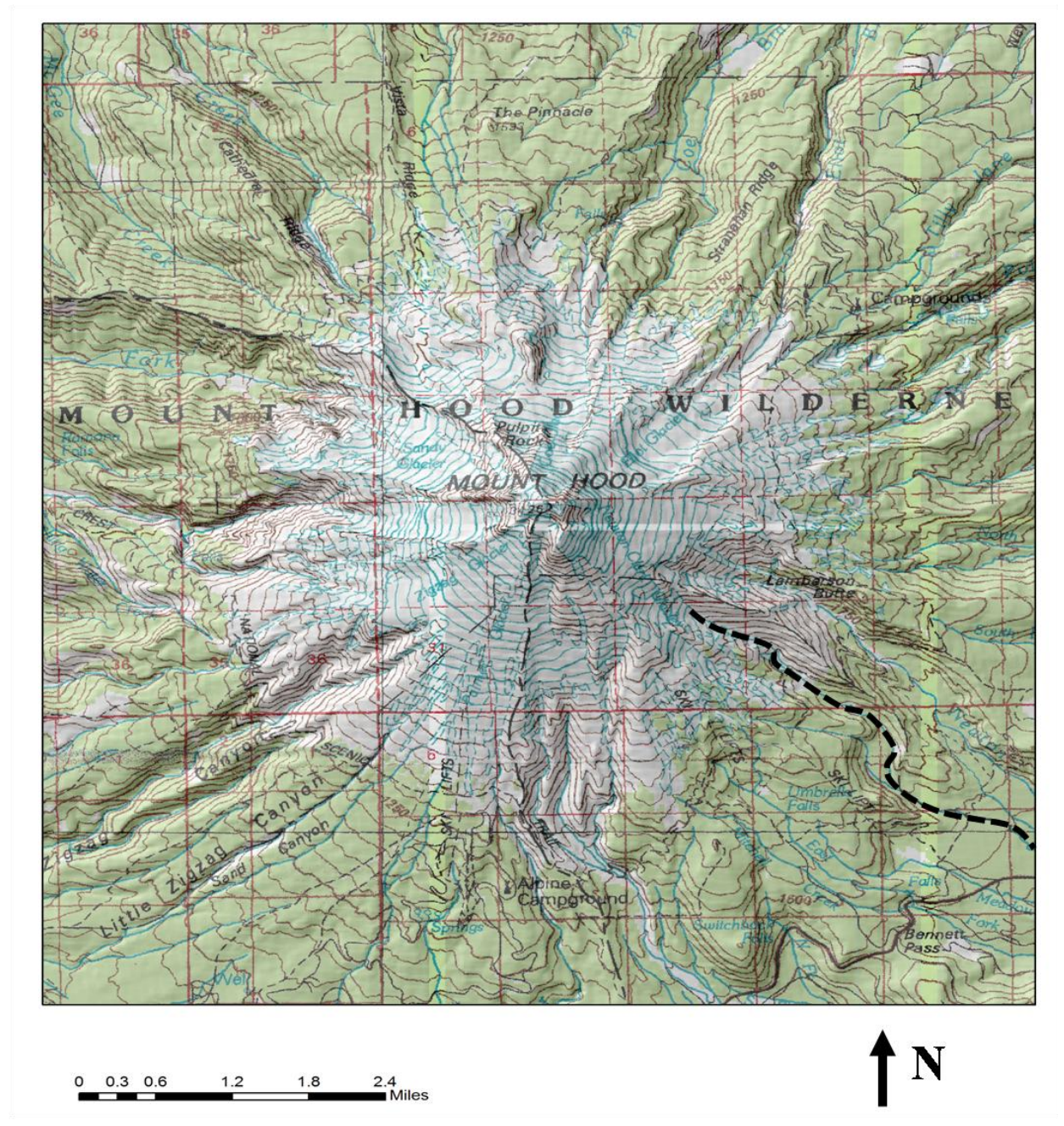

Figure 33. Clark Creek shown in dashed black

\section{Reconnaissance \& Sample Collection:}

\section{Initial Reconnaissance}

At the point where Elk Meadows Trail crosses Clark Creek there were no obvious signs of debris flow processes. A trail bridge had been damaged by flooding; however, no identifying debris flow characteristics were present. There were signs of significant erosion of stream banks in the area; however, there was also a lot of vegetation in and near the stream channel. Where the Timberline Trail crosses the 
Clark Creek there were boulder levees present, a distinct lack of vegetation in or near the stream channel and steep channel sidewalls recently subjected to vigorous erosion. Large landslides were also observed in some channel sidewalls. Therefore, this drainage was classified as having a debris flow.

\section{Definition of Initiation Zone}

The initiation zone was defined by a landslide in the sidewall material near the Timberline Trail crossing (Figure 34). This landslide was chosen to mark the initiation zone as it was the largest identifiable input for sediment into the system. Note that this volume is really low compared to Eliot Creek landslides that generated large debris flows. However, there was evidence of erosion and a lack of vegetation upstream from this point as well. There may have been some minor additional upstream input to the Clark Creek debris flow. However, directly upstream from the landslide, Clark Creek retreats to rocky headwaters. The rock in the Clark Creek headwaters is bounded by ancient pyroclastic flow and debris flow deposits comprised of unconsolidated, unvegetated sediment (Sherrod \& Scott, 1995).

\section{Sample Collection}

Six samples were collected from material considered to be representative of the initiation zone due to the fact that it comes from the same geologic unit (Figure 35). Samples were collected at the elevation of the initiation zone. 


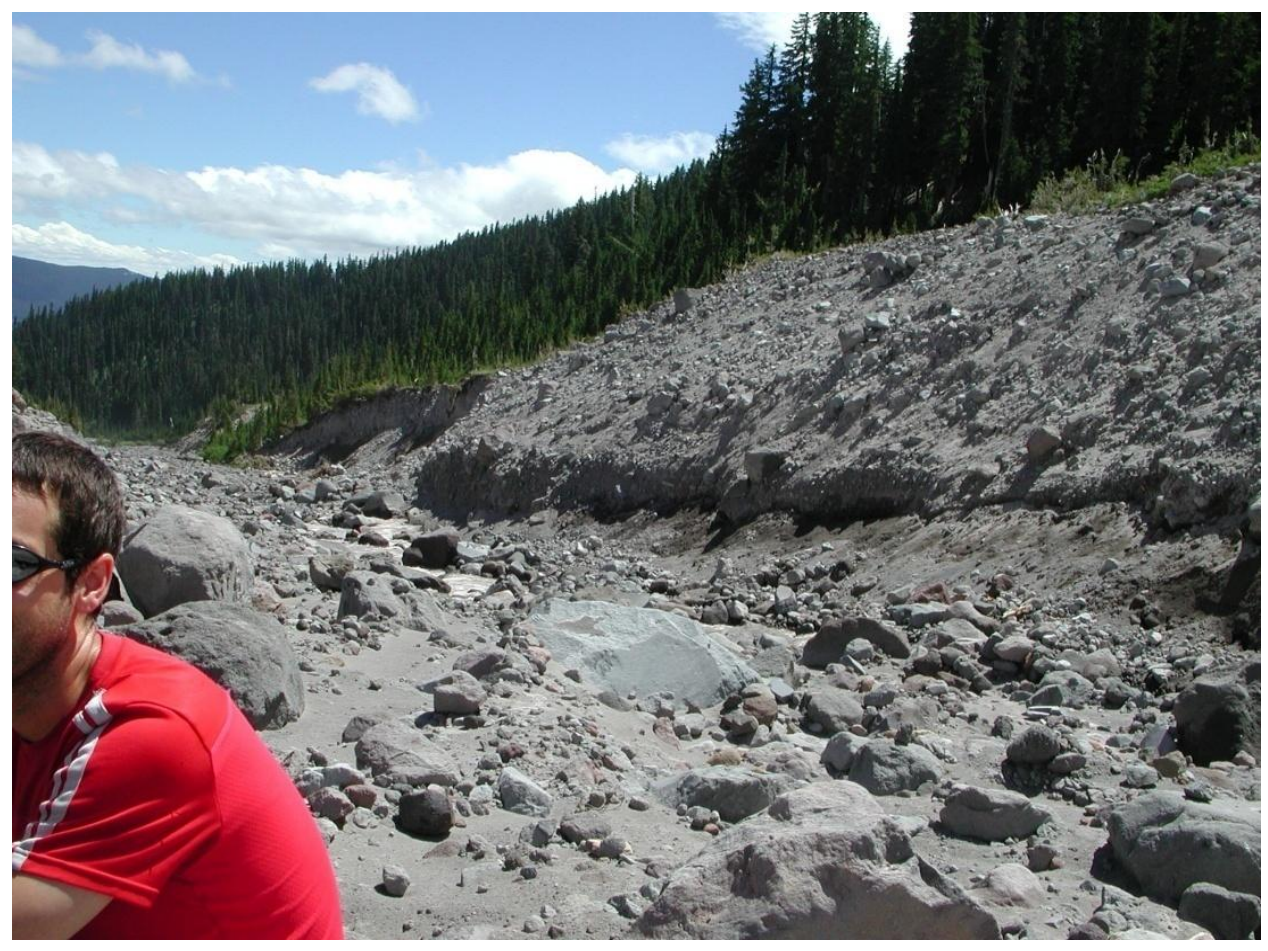

Figure 34. Clark Creek initiation zone $\left(\sim 4,860 \mathrm{~m}^{3}\right.$ ) (UTM 0604875N, 5022881E)

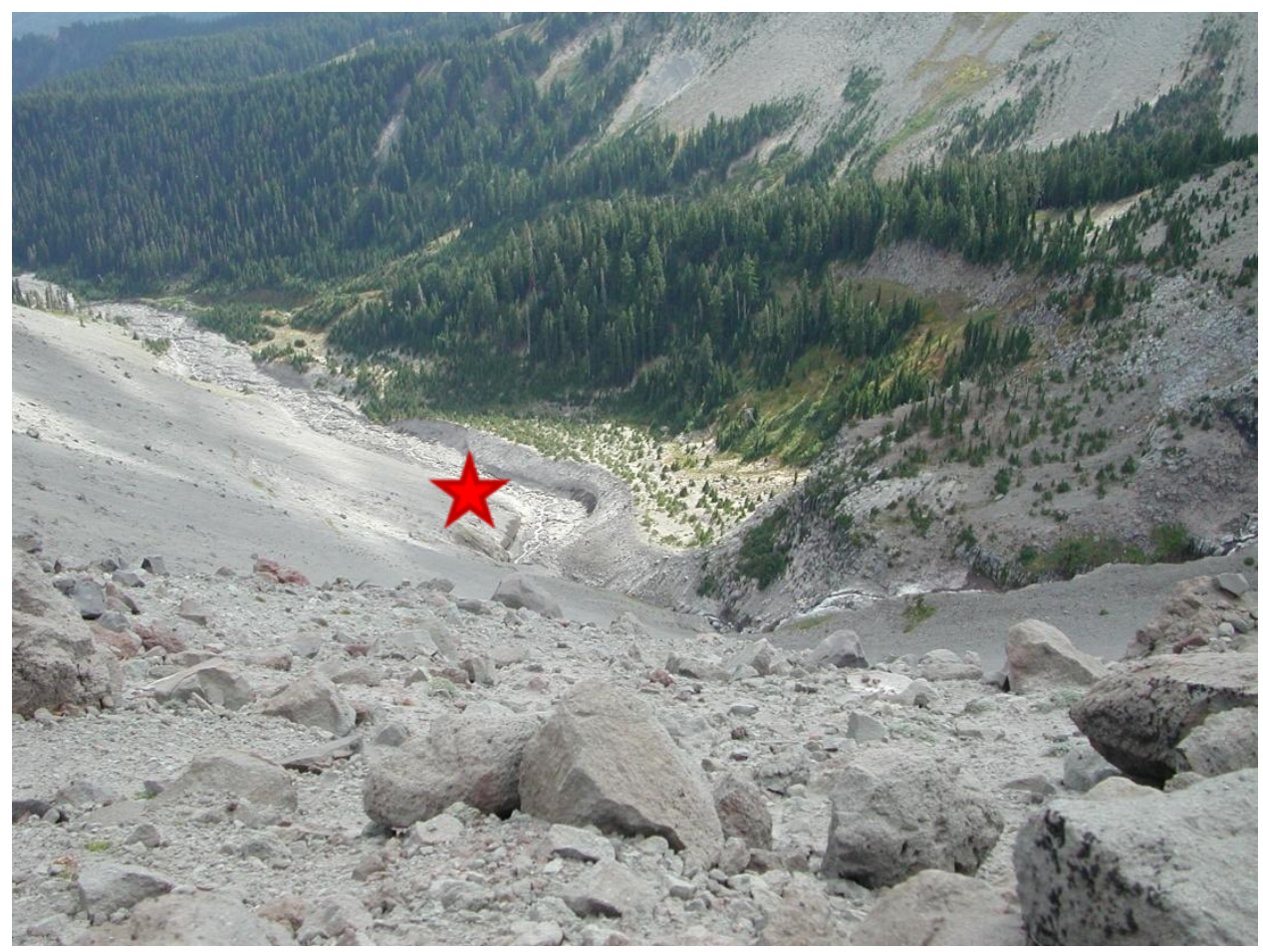

Figure 35. Clark Creek sample collection site (UTM 0605216N, 5022626E) 


\section{Data Processing:}

\section{Sieve Results}

Sieve results for samples collected in Clark Creek were averaged and are shown in Table 6. Material from the Clark Creek initiation zone has an average bulk density of $1.7 \mathrm{~g} / \mathrm{cm}^{3}$. The average sample is $36.7 \%$ gravel, $59.9 \%$ sand, and $3.3 \%$ fine grained material. Of the sand, coarse grained material is in the clear majority with $67 \%$.

Table 6. Clark Creek sieve results

\begin{tabular}{|c|c|c|c|c|c|c|c|}
\hline \multirow[b]{2}{*}{$\begin{array}{c}\text { Clark Creek } \\
\text { Sample \# }\end{array}$} & \multirow{2}{*}{$\begin{array}{c}\text { Bulk } \\
\text { Density } \\
\left(\mathrm{g} / \mathrm{cm}^{3}\right)\end{array}$} & \multirow[b]{2}{*}{$\begin{array}{l}\text { Gravel } \\
>2 \mathrm{~mm}\end{array}$} & \multirow[b]{2}{*}{$\begin{array}{l}\text { Sand } \\
2 \mathrm{~mm}- \\
.063 \mathrm{~mm}\end{array}$} & \multirow{2}{*}{$\begin{array}{c}\text { Silt \& } \\
\text { Clay } \\
<.063 \mathrm{~mm}\end{array}$} & \multicolumn{3}{|c|}{ Sand } \\
\hline & & & & & $\begin{array}{c}\text { Coarse } \\
2 \mathrm{~mm}- \\
.25 \mathrm{~mm} \\
\end{array}$ & $\begin{array}{c}\text { Medium } \\
.25 \mathrm{~mm}- \\
.149 \mathrm{~mm} \\
\end{array}$ & $\begin{array}{c}\text { Fine } \\
.149 \mathrm{~mm}- \\
.063 \mathrm{~mm} \\
\end{array}$ \\
\hline 1 & 1.6 & $58.6 \%$ & $39.8 \%$ & $1.6 \%$ & $70.2 \%$ & $17.4 \%$ & $12.3 \%$ \\
\hline 2 & 1.7 & $38.9 \%$ & $57.8 \%$ & $3.2 \%$ & $69.4 \%$ & $15.3 \%$ & $15.3 \%$ \\
\hline 3 & 1.3 & $14.0 \%$ & $81.6 \%$ & $4.2 \%$ & $52.1 \%$ & $27.9 \%$ & $20.0 \%$ \\
\hline 4 & 1.8 & $24.8 \%$ & $68.9 \%$ & $6.1 \%$ & $61.4 \%$ & $19.9 \%$ & $18.7 \%$ \\
\hline 5 & 1.7 & $45.3 \%$ & $51.9 \%$ & $2.6 \%$ & $71.9 \%$ & $15.8 \%$ & $12.4 \%$ \\
\hline 6 & 1.9 & $38.4 \%$ & $59.3 \%$ & $2.0 \%$ & $78.4 \%$ & $12.9 \%$ & $8.6 \%$ \\
\hline Average & 1.7 & $36.7 \%$ & $59.9 \%$ & $3.3 \%$ & $67.2 \%$ & $18.2 \%$ & $14.5 \%$ \\
\hline Standard dev. & $23 \%$ & $16 \%$ & $14 \%$ & $2 \%$ & $9 \%$ & $5 \%$ & $4 \%$ \\
\hline
\end{tabular}

\section{Drainage Basin Attributes}

The total basin catchment area for the Clark Creek Drainage is $5.9 \mathrm{~km}^{2}$ with an upper drainage basin area of $3.9 \mathrm{~km}^{2}$. The initiation zone is located between the elevations of 1,720 and 1,760 meters and is 610 meters from the Newton-Clark Glacier which has an area of approximately $1,390,000 \mathrm{~m}^{2}$. The upper drainage basin is $7.5 \%$ bedrock with $26.7 \%$ of the basin covered in vegetation. Steep unconsolidated and unvegetated slopes account for $26.6 \%$ of the upper basin. Sediment type in the 
initiation zone is predominantly neoglacial till and pyroclastic flow deposits (Sherrod \& Scott, 1995) and received approximately $15 \mathrm{~cm}$ of rain in the November, 2006 storm which triggered the debris flows (NEXRAD, 2009). The overall azimuth of the upper drainage is $132^{\circ}$. The maximum elevation for the basin catchment area above the fan was calculated at 3,060 meters with a minimum of 1,392 meters. Basin height is 1,668 meters. Stream gradient for the upper drainage basin is about .16 . Melton's Ruggedness number for this basin has been calculated at $\mathrm{R}=0.68$.

\section{SALMON RIVER (EAST FORK) DRAINAGE:}

The east fork of the Salmon River is located on the south side of the mountain (Figure 36). The Salmon River drainage experienced a small debris flow, travelling approximately $4 \mathrm{~km}$, as a result of the November, 2006 storm. The investigation into the Salmon River Basin included a field based reconnaissance, sample collection and data processing.

\section{Reconnaissance \& Sample Collection:}

\section{Initial Reconnaissance}

The Timberline Trail crosses the east fork of the Salmon River near the Timberline Lodge. At this point fresh boulder levees, as shown in Figure 37, fresh unsorted matrix supported deposits, and lack of vegetation indicate a recent debris flow. The flow seems small compared to others on the mountain. Where vegetation is present, it is covered by a light layer of sandy and gravelly debris. 


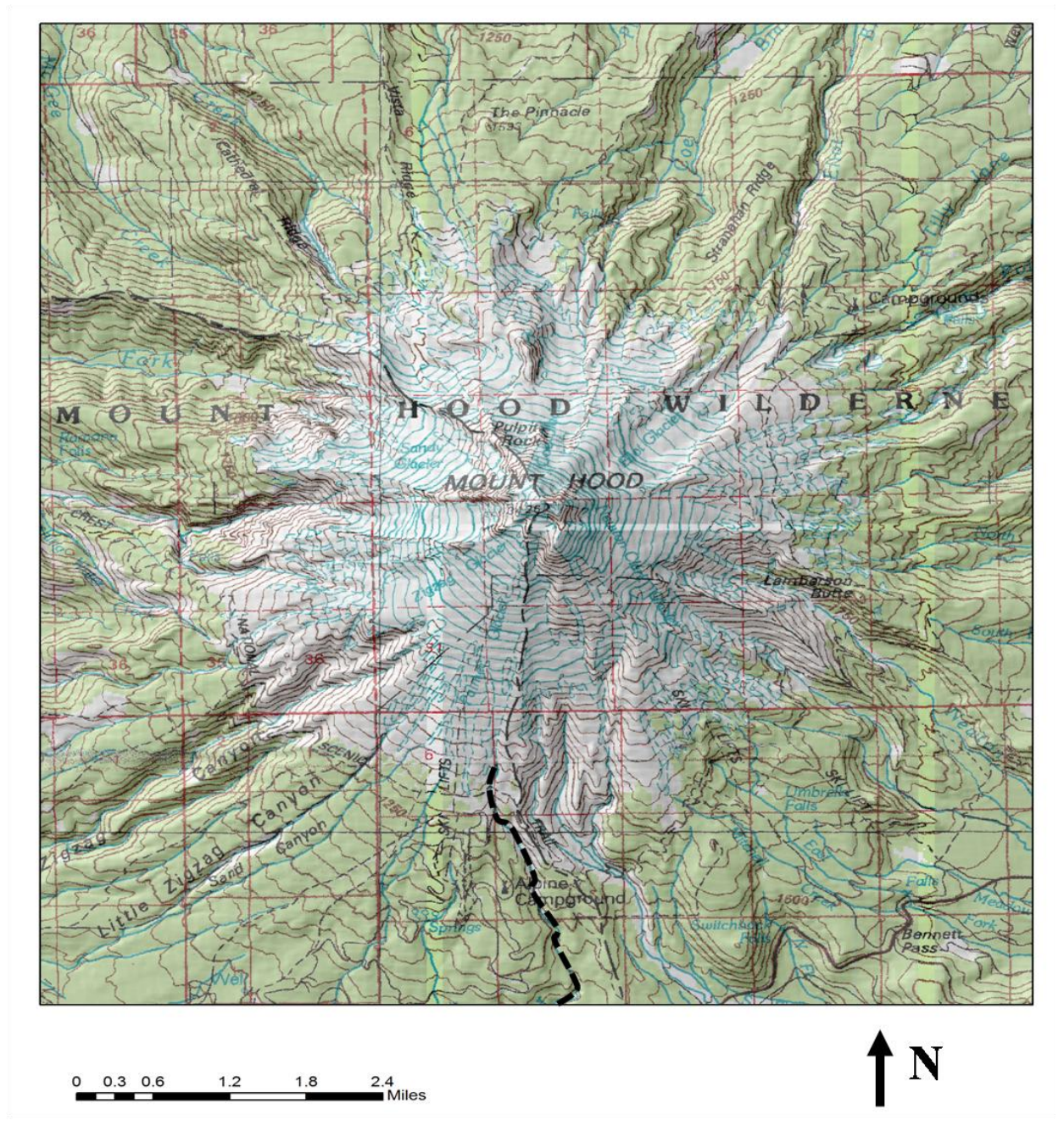

Figure 36. Salmon River shown in dashed black

\section{Definition of Initiation Zone}

Debris flow levees and bouldery material were followed upstream until they disappeared under snow. The snow fingered down into the channel from the Palmer Snow Field and fluctuated seasonally. No distinct landslide or rills were identified as the upper reaches of this stream remained covered by snow for the field season. Due to the lack of a discrete initiation point, this drainage was considered a headless debris flow. 


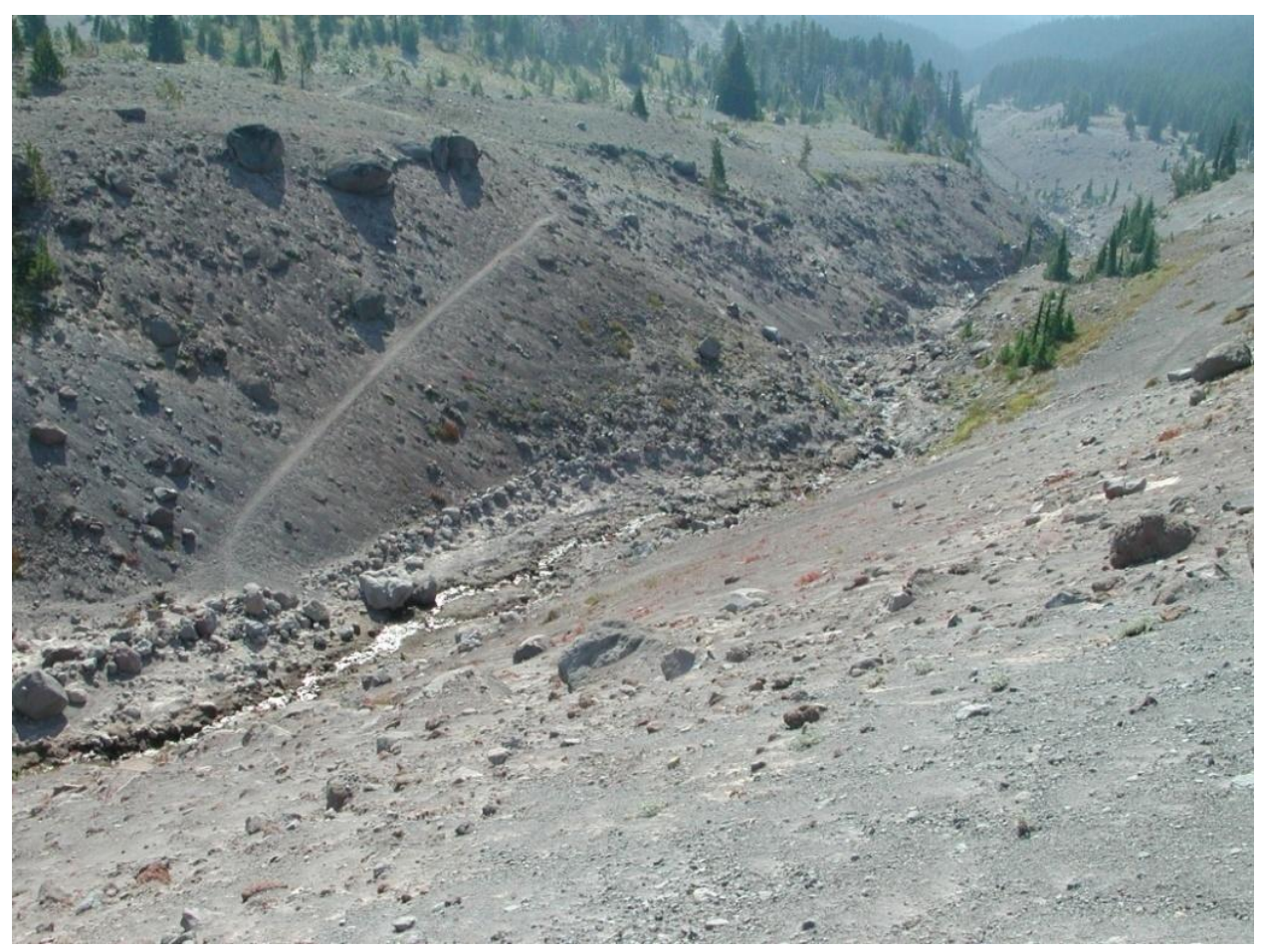

Figure 37. Salmon River boulder levees

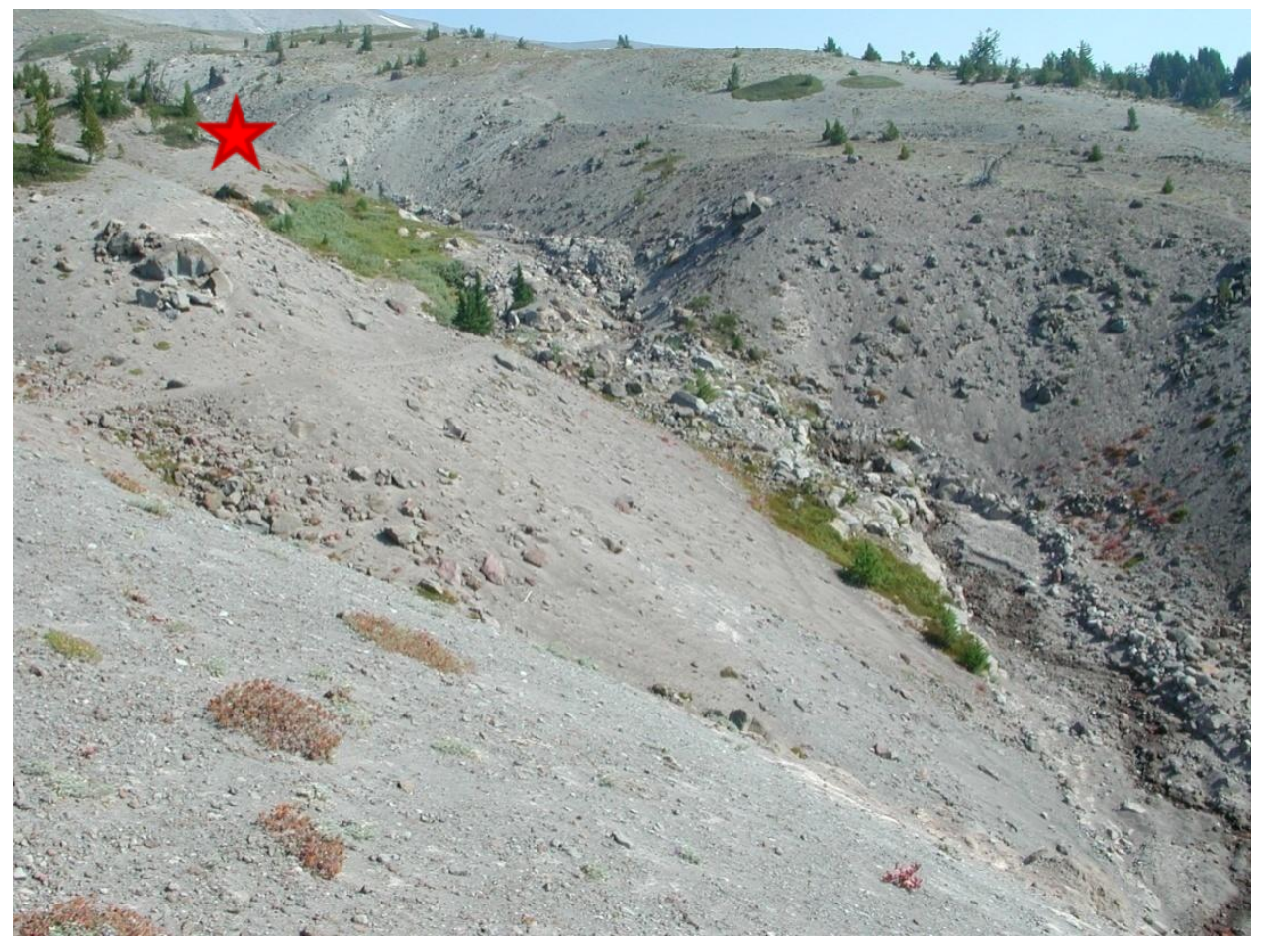

Figure 38 Salmon River sample collection site (UTM 0601358N, 5021270E) 


\section{Sample Collection}

Samples were collected in unconsolidated pyroclastic material below the source area and are representative of the parent material in source area (Figure 38).

\section{Data Processing:}

\section{Sieve Results}

Results of the sieve analysis on samples collected from the east fork of the Salmon River are averaged and shown in Table 7. Material from the Salmon River initiation zone equivalent has an average bulk density of $1.7 \mathrm{~g} / \mathrm{cm}^{3}$. The average sample contains $46.3 \%$ gravel, $51.9 \%$ sand, and $1.7 \%$ fine grained material. Of the sand, coarse grained material is in the clear majority with almost $80 \%$.

Table 7. Salmon River sieve results

\begin{tabular}{|c|r|r|r|r|r|r|r|}
\hline $\begin{array}{c}\text { Salmon River } \\
\text { Sample \# }\end{array}$ & $\begin{array}{c}\text { Bulk } \\
\text { Density } \\
\left(\mathbf{g} / \mathbf{c m}^{\mathbf{3}} \mathbf{)}\right.\end{array}$ & $\begin{array}{c}\text { Gravel } \\
>2 \mathrm{~mm}\end{array}$ & $\begin{array}{c}\text { Sand } \\
2 \mathrm{~mm}- \\
.063 \mathrm{~mm}\end{array}$ & $\begin{array}{c}\text { Silt \& } \\
\text { Clay } \\
<.063 \mathrm{~mm}\end{array}$ & $\begin{array}{c}\text { Coarse } \\
2 \mathrm{~mm}-\end{array}$ & $\begin{array}{c}\text { Medium } \\
.25 \mathrm{~mm}-\end{array}$ & $\begin{array}{c}\text { Fine } \\
.149 \mathrm{~mm}-\end{array}$ \\
& 1.8 & $48.6 \%$ & $49.6 \%$ & $1.6 \%$ & $79.7 \%$ & $12.0 \%$ & $8.3 \%$ \\
\hline $\mathbf{1}$ & 1.8 & $45.1 \%$ & $53.1 \%$ & $1.8 \%$ & $79.7 \%$ & $11.8 \%$ & $8.5 \%$ \\
$\mathbf{2}$ & 1.5 & $48.9 \%$ & $49.3 \%$ & $1.6 \%$ & $80.0 \%$ & $11.9 \%$ & $8.1 \%$ \\
$\mathbf{3}$ & 1.7 & $45.4 \%$ & $52.8 \%$ & $1.7 \%$ & $80.4 \%$ & $11.4 \%$ & $8.2 \%$ \\
$\mathbf{4}$ & 1.6 & $42.1 \%$ & $55.9 \%$ & $1.9 \%$ & $79.8 \%$ & $11.4 \%$ & $8.8 \%$ \\
$\mathbf{5}$ & 1.7 & $47.8 \%$ & $50.6 \%$ & $1.6 \%$ & $79.7 \%$ & $11.7 \%$ & $8.6 \%$ \\
$\mathbf{6}$ & 1.7 & $46.3 \%$ & $51.9 \%$ & $1.7 \%$ & $79.9 \%$ & $11.7 \%$ & $8.4 \%$ \\
\hline Average & $12 \%$ & $3 \%$ & $3 \%$ & $0 \%$ & $0 \%$ & $0 \%$ & $0 \%$ \\
\hline Standard dev. & & & & & & & \\
\hline
\end{tabular}

\section{Drainage Basin Attributes}

The total basin catchment area for the Salmon River is $12.8 \mathrm{~km}^{2}$ with an upper drainage basin area of $1.4 \mathrm{~km}^{2}$. The initiation zone is located between the elevations 
of 2,020 and 2,200 meters and is approximately 671 meters from the Palmer Snow Field which has an area of approximately $130,000 \mathrm{~m}^{2}$ (Driedger \& Kannard, 1986). The upper drainage basin is $0 \%$ bedrock with $4.1 \%$ of the upper basin covered in vegetation. Steep unconsolidated and unvegetated slopes account for $9.3 \%$ of the upper basin. Sediment type in the initiation zone is predominantly pyroclastic flow and debris flow deposits (Sherrod \& Scott, 1995) and received approximately $15 \mathrm{~cm}$ of rain in the November, 2006 storm which triggered the debris flows (NEXRAD, 2009). The overall azimuth of the upper drainage is $187^{\circ}$. The maximum elevation for the basin catchment area above the fan was calculated at 2,777 meters with a minimum of 1,222 meters. Basin height is 1,555 meters. Stream gradient for the upper drainage basin is approximately .23. Melton's Ruggedness Number for this basin has been calculated at $R=0.43$.

\section{LADD CREEK DRAINAGE BASIN:}

Ladd Creek is located on the northwest side of the mountain as shown in Figure 39. The Ladd Creek drainage experienced a small debris flow, travelling approximately $4 \mathrm{~km}$, as a result of the November, 2006 storm. The investigation into the Ladd Basin included a field based reconnaissance, sample collection and data processing. 


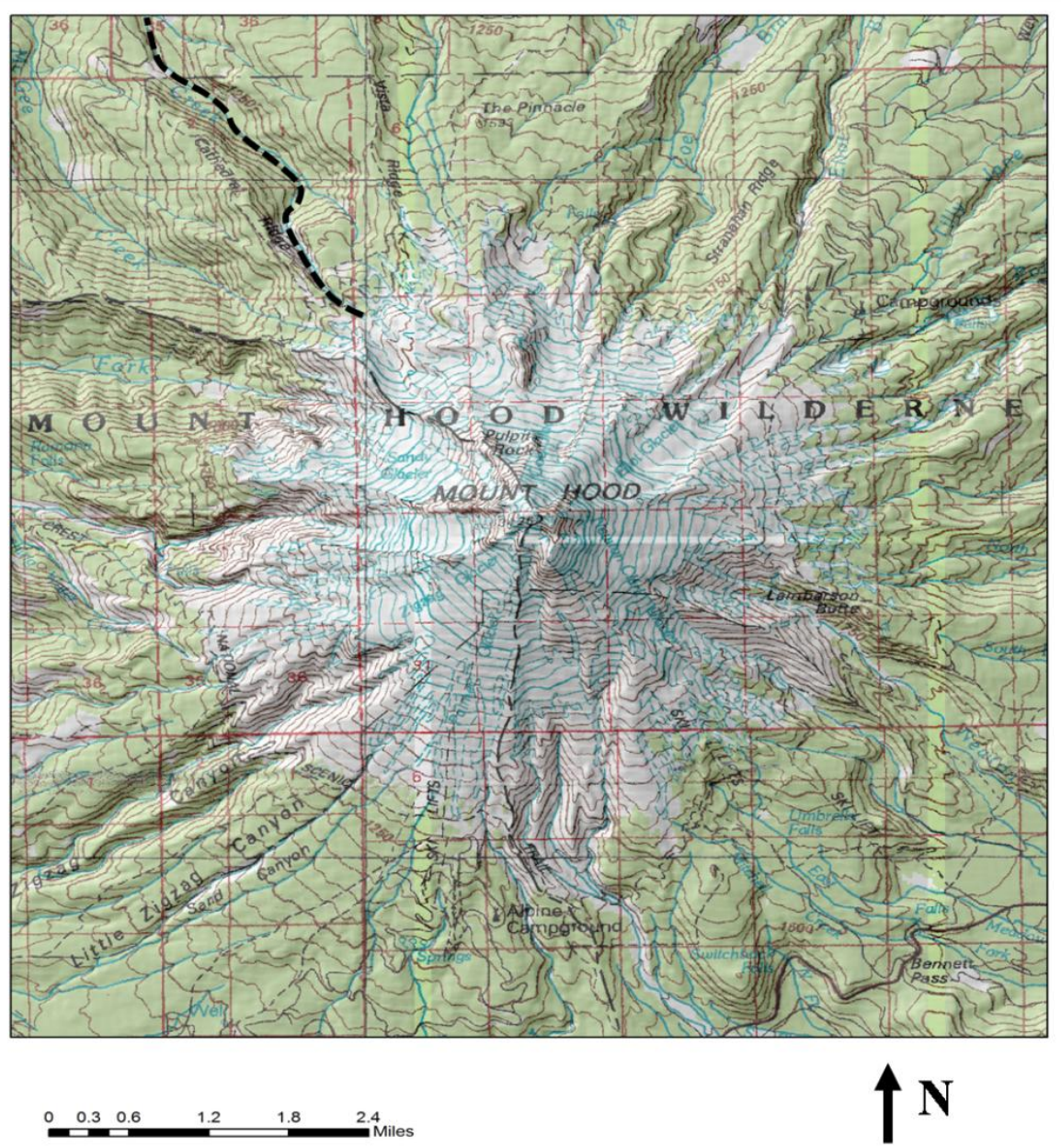

Figure 39. Ladd Creek shown in dashed black

\section{Reconnaissance \& Sample Collection:}

\section{Initial Reconnaissance}

At the old Cathedral Ridge trailhead Ladd Creek can be seen in the canyon below.

At this point there was no evidence for debris flow activity. Heavy vegetation

abutted to the channel, and there was no indication of fresh debris flow deposits or boulder levees. Where the Timberline Trail crosses Ladd Creek abundant evidence was present for debris flow activity. Debris flow deposits of boulder and unsorted 
matrix supported debris were present in the channel. Trees that had been broken were present and also had some mud coatings with small pebbles imbedded in the wood. Many small sides and signs of fresh erosion were present on the stream banks. Distinct fresh boulder levees present along stream channel are shown in Figure 40. The debris trail disappears downstream over a large knick-point in a steep, cliff lined section of the stream. There is no evidence for debris flows on accessible areas of the fan below the constricted canyon area. However, an abundance of upstream evidence of debris flow activity indicates that Ladd Creek did experience a debris flow which most likely became blocked up in the canyon and consequently did not reach the fan.

\section{Definition of Initiation Zone}

At the constriction point, in the upper reaches of the Ladd Creek drainage, where the terminal moraines come together and the river incises, there is a small landslide. Ladd Creek flows at the base of the slide and the landslide deposit has been washed downstream. Below this point there is evidence of debris flow activity including extensive fresh erosion, lack of vegetation in or near the channel, and the presence of boulder levees. Above this point there are no boulder levees, some vegetation near the channel, and no sign of fresh erosion. Therefore, this landslide (Figure 41,)

was selected to represent the initiation zone. This landslide $\left(\sim 3,060 \mathrm{~m}^{3}\right)$ is significantly smaller than other initiation zone landslides. 


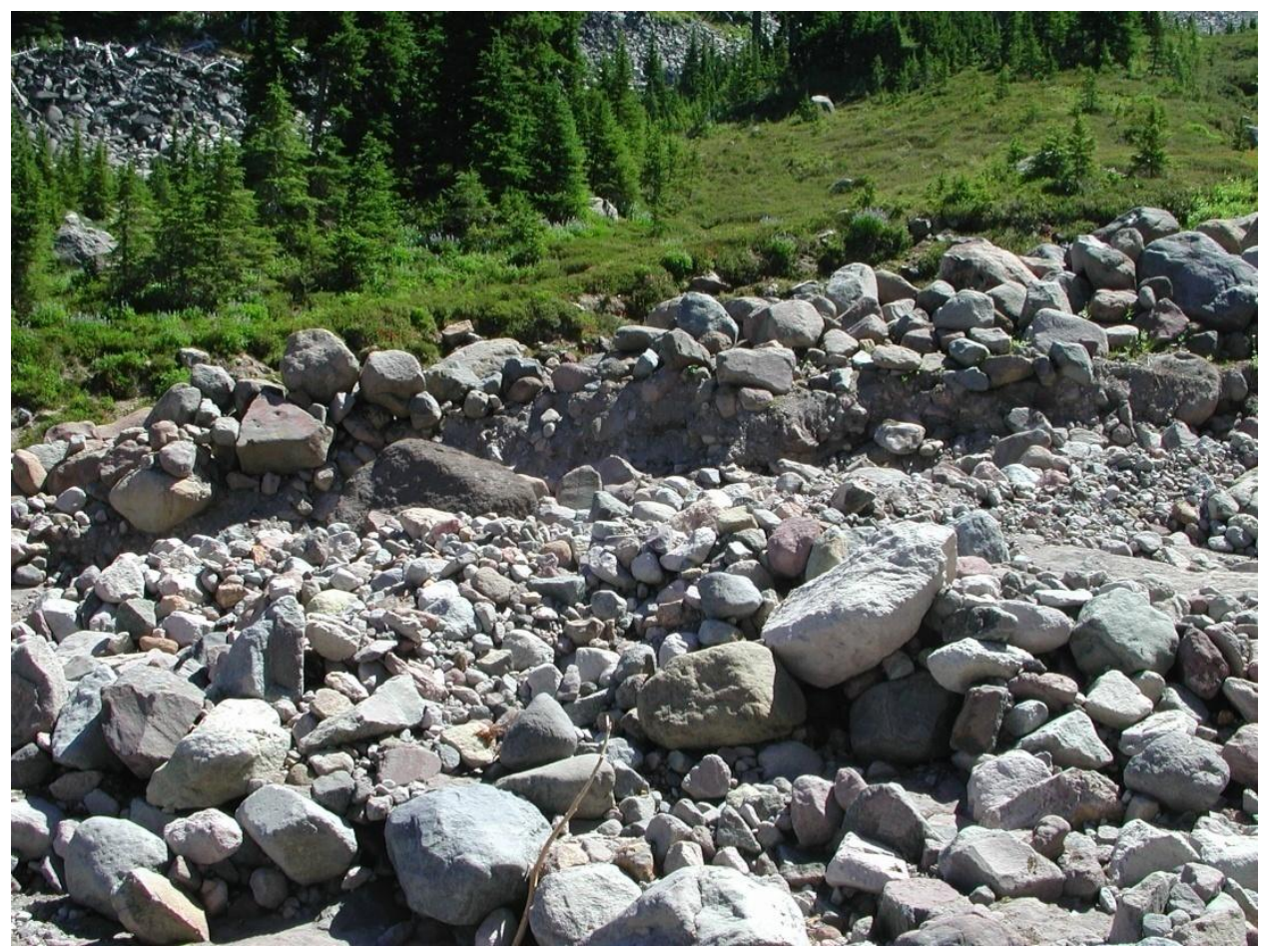

Figure 40. Ladd Creek boulder levees

\section{Sample Collection}

Six samples were collected adjacent to the landslide headscarp (Figure 41).

\section{Data Processing:}

\section{Sieve Results}

Samples were sieved and averaged together as shown in Table 8. Material from the Ladd Creek initiation zone has an average bulk density of $1.7 \mathrm{~g} / \mathrm{cm}^{3}$. The average sample contains $49.4 \%$ gravel, $47.2 \%$ sand, and $2.4 \%$ fine grained material. Of the sand, coarse grained material is in the clear majority with near $73 \%$. 


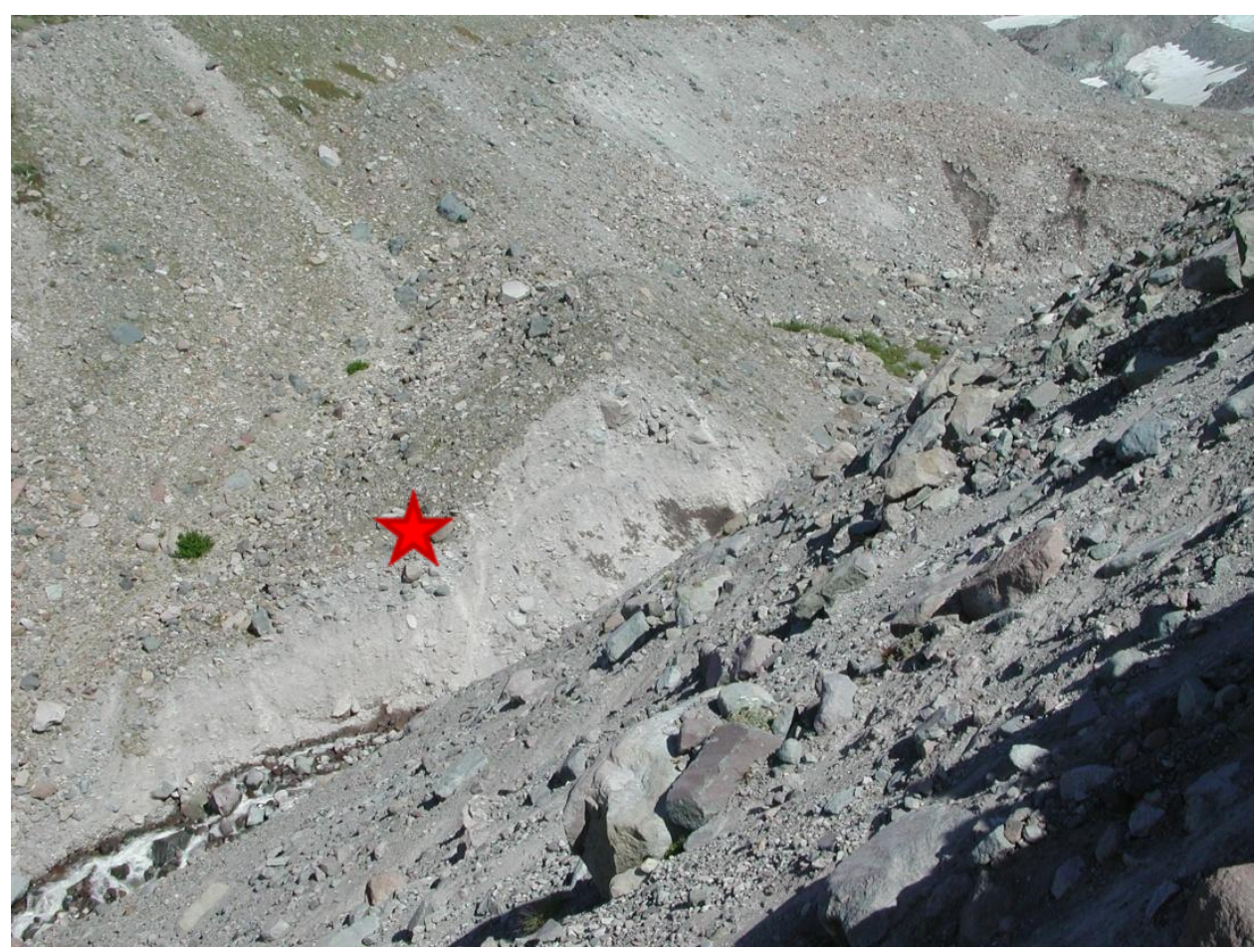

Figure 41. Ladd Creek initiation zone $\left(\sim 3,060 \mathrm{~m}^{3}\right)$ \& sample collection site (UTM 0600239N, 5027916E) Table 8. Ladd Creek sieve results

\begin{tabular}{|c|c|c|c|c|c|c|c|}
\hline \multirow[b]{2}{*}{$\begin{array}{c}\text { Ladd Creek } \\
\text { Sample \# }\end{array}$} & \multirow{2}{*}{$\begin{array}{c}\text { Bulk } \\
\text { Density } \\
\left(\mathrm{g} / \mathrm{cm}^{3}\right)\end{array}$} & \multirow[b]{2}{*}{$\begin{array}{l}\text { Gravel } \\
>2 \mathrm{~mm}\end{array}$} & \multirow[b]{2}{*}{$\begin{array}{l}\text { Sand } \\
2 \mathrm{~mm}- \\
.063 \mathrm{~mm}\end{array}$} & \multirow{2}{*}{$\begin{array}{c}\text { Silt \& } \\
\text { Clay } \\
<.063 \mathrm{~mm}\end{array}$} & \multicolumn{3}{|c|}{ Sand } \\
\hline & & & & & $\begin{array}{c}\text { Coarse } \\
2 \mathrm{~mm}- \\
.25 \mathrm{~mm} \\
\end{array}$ & $\begin{array}{c}\text { Medium } \\
.25 \mathrm{~mm}- \\
.149 \mathrm{~mm} \\
\end{array}$ & $\begin{array}{c}\text { Fine } \\
.149 \mathrm{~mm}- \\
.063 \mathrm{~mm}\end{array}$ \\
\hline 1 & 1.6 & $49.8 \%$ & $48.8 \%$ & $0.4 \%$ & $88.4 \%$ & $6.9 \%$ & $4.8 \%$ \\
\hline 2 & 1.7 & $57.3 \%$ & $40.8 \%$ & $1.6 \%$ & $66.5 \%$ & $14.5 \%$ & $18.9 \%$ \\
\hline 3 & 1.4 & $39.5 \%$ & $58.0 \%$ & $0.5 \%$ & $80.6 \%$ & $12.5 \%$ & $6.9 \%$ \\
\hline 4 & 1.9 & $68.4 \%$ & $26.6 \%$ & $4.6 \%$ & $55.8 \%$ & $10.8 \%$ & $33.4 \%$ \\
\hline 5 & 2.1 & $18.3 \%$ & $73.9 \%$ & $5.7 \%$ & $64.4 \%$ & $17.1 \%$ & $18.5 \%$ \\
\hline 6 & 1.6 & $63.2 \%$ & $34.9 \%$ & $1.8 \%$ & $79.6 \%$ & $10.9 \%$ & $9.6 \%$ \\
\hline Average & 1.7 & $49.4 \%$ & $47.2 \%$ & $2.4 \%$ & $72.5 \%$ & $12.1 \%$ & $15.3 \%$ \\
\hline Standard dev. & $25 \%$ & $18 \%$ & $17 \%$ & $2 \%$ & $12 \%$ & $4 \%$ & $11 \%$ \\
\hline
\end{tabular}

\section{Drainage Basin Attributes}

The total basin catchment area for the Ladd Creek drainage is $20.0 \mathrm{~km}^{2}$ with an upper drainage basin area of $2.3 \mathrm{~km}^{2}$. The initiation zone is located between the 
elevations of 1,880 and 1,930 meters and is 1,010 meters from the Ladd Glacier which has an area of approximately $670,000 \mathrm{~m}^{2}$ (Jackson K. M., 2007; Jackson \& Fountain, 2007). The upper drainage basin is $11.8 \%$ bedrock with $13.9 \%$ of the upper basin covered in vegetation. Steep unconsolidated and unvegetated slopes account for $11.3 \%$ of the upper basin. Sediment type in the initiation zone is predominantly till of neo-glacial age and debris avalanche deposit of Ladd Creek (Sherrod \& Scott, 1995) and received approximately $36 \mathrm{~cm}$ of rain in the November, $2006 \mathrm{storm}$ which triggered the debris flows (NEXRAD, 2009). The overall azimuth of the upper drainage is $330^{\circ}$. The maximum elevation for the basin catchment area above the fan was calculated at 2,781 meters with a minimum of 1,323 meters. Basin height is 1,458 meters. Stream gradient for the upper drainage basin is approximately 19 . Melton's Ruggedness Number for this basin has been calculated at $R=0.33$.

\section{ZIGZAG RIVER DRAINAGE BASIN:}

The Zigzag River is located on the southwest side of the mountain as shown in Figure 42. The Zigzag River drainage did not experience a debris flow as a result of the November, 2006 storm. The investigation into the Zigzag basin included a field based reconnaissance, sample collection and data processing.

\section{Reconnaissance \& Sample Collection:}

\section{Initial Reconnaissance}




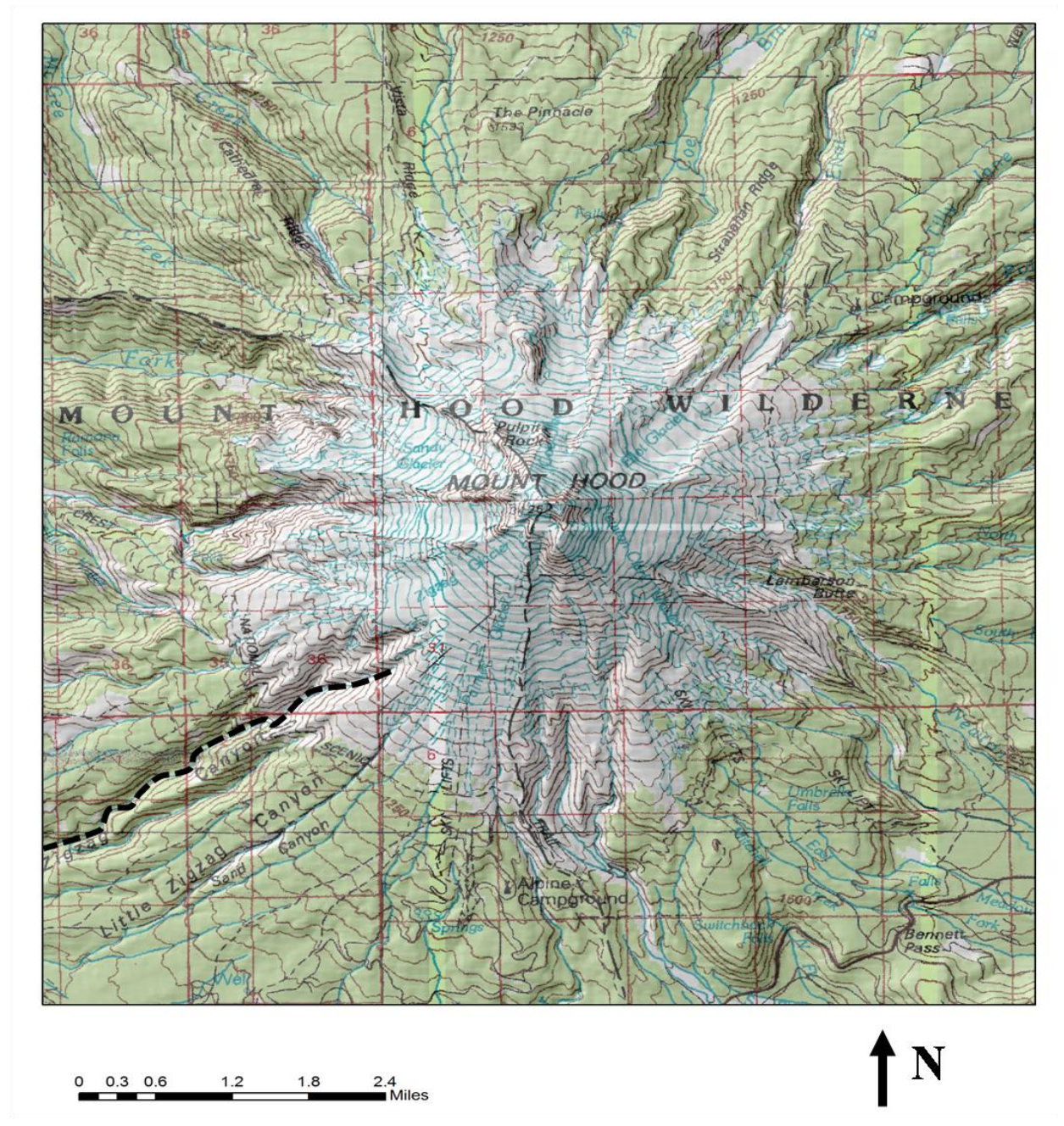

Figure 42. Zigzag River shown in dashed black

Lolo Pass road crosses the Zigzag River at an elevation of about 440 meters. At that point there was no evidence for debris flow occurrence. Stream channels had ample vegetation along the banks and showed no sign of recent debris flow deposits or levees. The Timberline Trail crosses the Zigzag River at an elevation of 1,450 meters. At this point some vegetation was noted near the river. Flattened shrubbery was observed along the active channel margin, and canyon walls were vegetated (Figure 43). There were no debris flow deposits and no mud-marks on 
trees or branches in or near the channel. Landslide head scarps were visible in the canyon walls; however, deposits are generally just below scarps and are vegetated. No evidence for recent debris flow activity was found for the Zigzag River.

\section{Sample Collection}

Samples were collected from a ridge on the north side of the drainage. Ridge top samples were selected as representative of initiation equivalent material due to difficult access to valley bottom exposures that satisfied the criteria of being above the timberline. Samples were collected above the timberline, but within alpine vegetated areas with ground hugging shrubbery (Figure 44). Abundant rainfall was ongoing during sample collection.

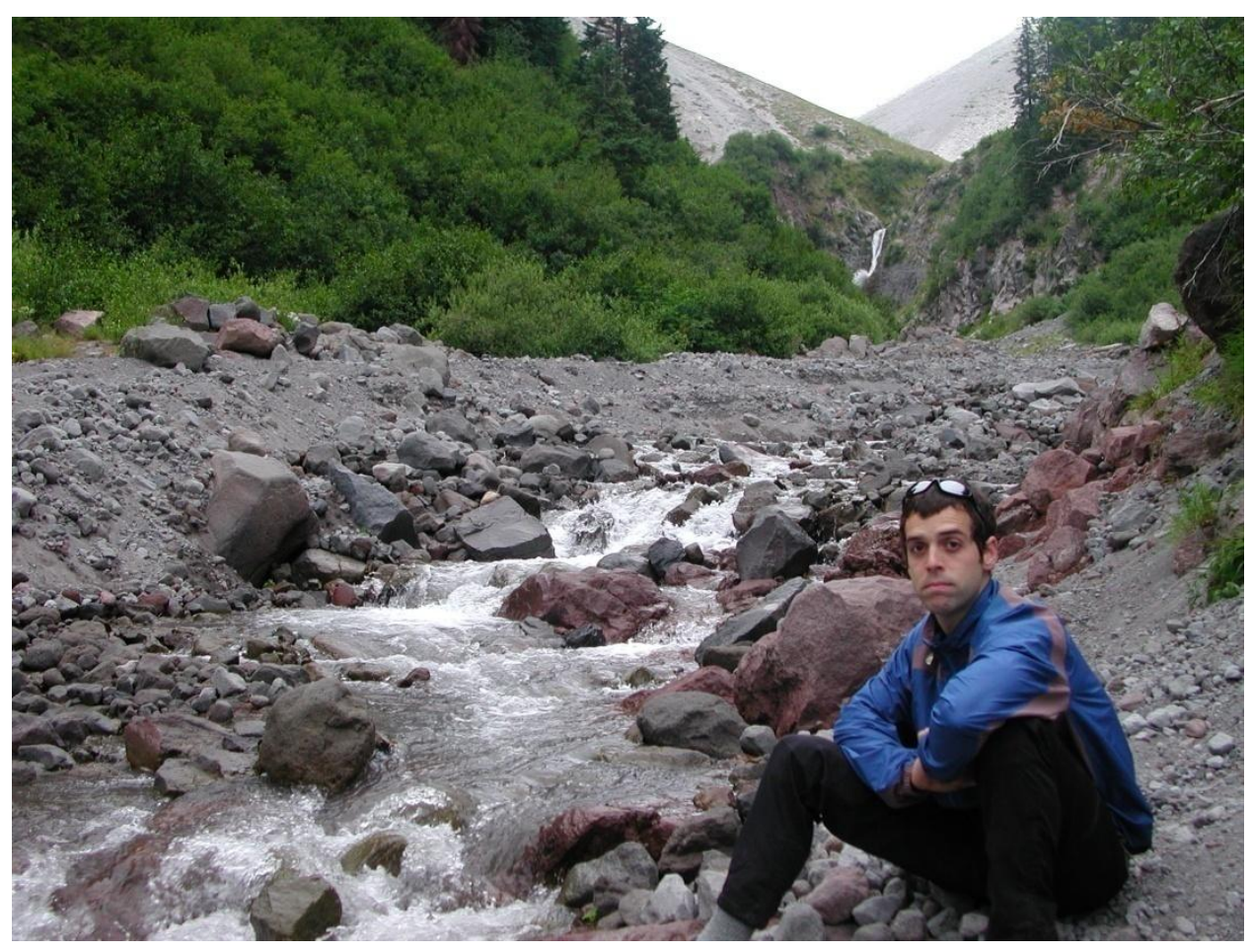

Figure 43. Zigzag River vegetation along active stream margin and canyon walls 


\section{Data Processing:}

\section{Sieve Results}

Samples were sieved and averaged together as shown in Table 9. Material from the upper Zigzag River drainage basin has an average bulk density of $1.7 \mathrm{~g} / \mathrm{cm}^{3}$. The average sample was $33.0 \%$ gravel, $61.3 \%$ sand, and $5.3 \%$ fine grained material. Of the sand, coarse grained material is in the clear majority with $66 \%$.

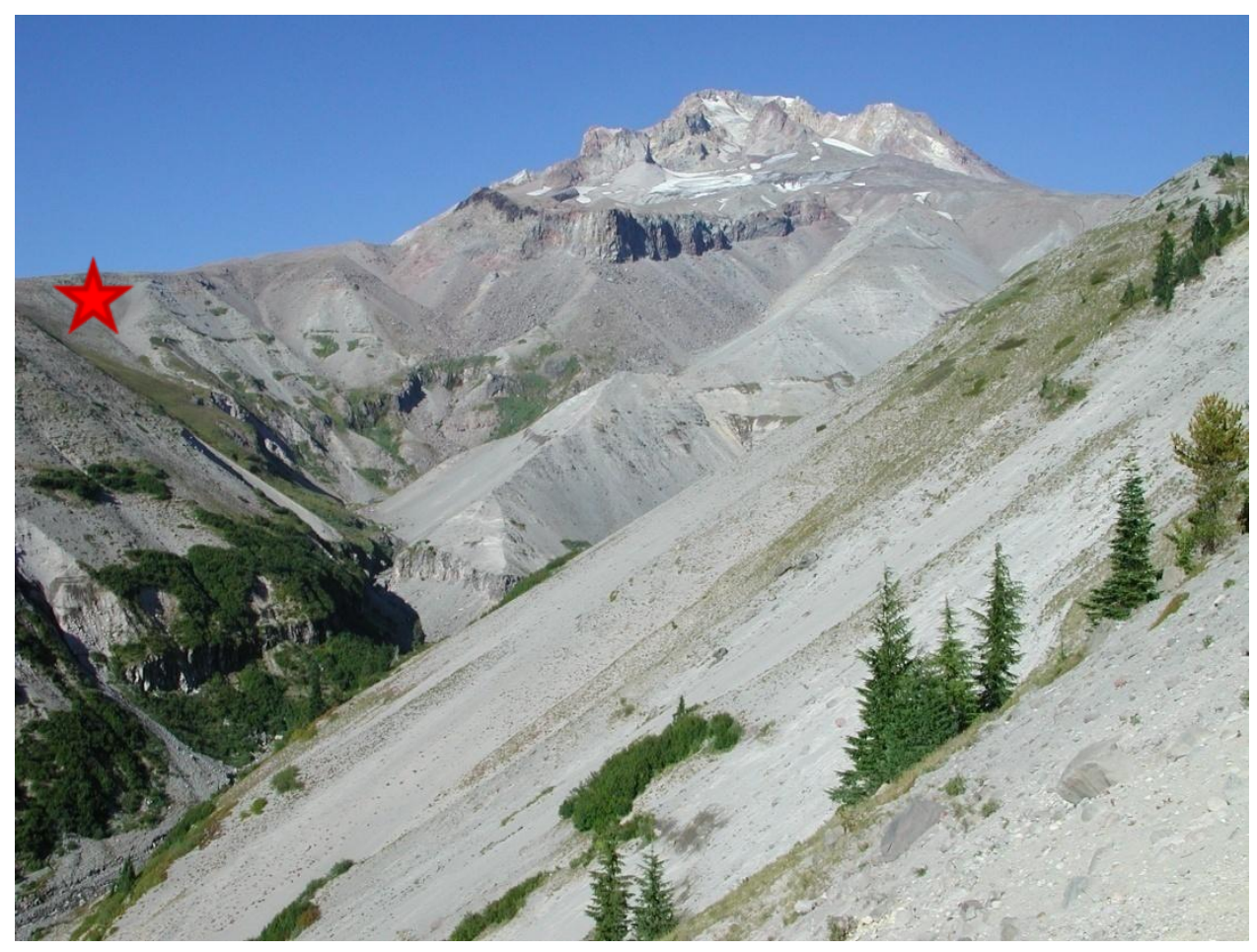

Figure 44. Zigzag River sample collection site (UTM 0598822N,5022666E)

\section{Drainage Basin Attributes}

The total basin catchment area for the Zigzag River is $34.3 \mathrm{~km}^{2}$ with an upper drainage basin area of $3.1 \mathrm{~km}^{2}$. This basin does not have direct connection to a 
Table 9. Zigzag River sieve results

\begin{tabular}{|c|c|c|c|c|c|c|c|}
\hline \multirow[b]{2}{*}{$\begin{array}{c}\text { Zigzag River } \\
\text { Sample \# }\end{array}$} & \multirow{2}{*}{$\begin{array}{c}\text { Bulk } \\
\text { Density } \\
\left(\mathrm{g} / \mathrm{cm}^{3}\right)\end{array}$} & \multirow[b]{2}{*}{$\begin{array}{l}\text { Gravel } \\
>2 \mathrm{~mm}\end{array}$} & \multirow[b]{2}{*}{$\begin{array}{l}\text { Sand } \\
2 \mathrm{~mm}- \\
.063 \mathrm{~mm}\end{array}$} & \multirow[b]{2}{*}{$\begin{array}{c}\text { Silt \& } \\
\text { Clay } \\
<.063 \mathrm{~mm}\end{array}$} & \multicolumn{3}{|c|}{ Sand } \\
\hline & & & & & $\begin{array}{c}\text { Coarse } \\
2 \mathrm{~mm}- \\
.25 \mathrm{~mm} \\
\end{array}$ & $\begin{array}{c}\text { Medium } \\
.25 \mathrm{~mm}- \\
.149 \mathrm{~mm} \\
\end{array}$ & $\begin{array}{c}\text { Fine } \\
.149 \mathrm{~mm}- \\
.063 \mathrm{~mm} \\
\end{array}$ \\
\hline 1 & 1.7 & $40.9 \%$ & $50.3 \%$ & $8.3 \%$ & $64.3 \%$ & $17.0 \%$ & $18.7 \%$ \\
\hline 2 & 1.8 & $33.3 \%$ & $60.8 \%$ & $5.5 \%$ & $66.5 \%$ & $16.7 \%$ & $16.8 \%$ \\
\hline 3 & 1.7 & $45.9 \%$ & $48.9 \%$ & $4.7 \%$ & $68.1 \%$ & $15.0 \%$ & $16.9 \%$ \\
\hline 4 & 1.4 & $10.9 \%$ & $86.6 \%$ & $2.1 \%$ & $61.3 \%$ & $24.1 \%$ & $14.6 \%$ \\
\hline 5 & 1.9 & $35.0 \%$ & $58.7 \%$ & $6.1 \%$ & $67.8 \%$ & $15.9 \%$ & $16.3 \%$ \\
\hline 6 & 1.5 & $32.1 \%$ & $62.3 \%$ & $5.3 \%$ & $68.2 \%$ & $14.6 \%$ & $17.2 \%$ \\
\hline Average & 1.7 & $33.0 \%$ & $61.3 \%$ & $5.3 \%$ & $66.0 \%$ & $17.2 \%$ & $16.8 \%$ \\
\hline Standard dev. & $18 \%$ & $12 \%$ & $14 \%$ & $2 \%$ & $3 \%$ & $3 \%$ & $1 \%$ \\
\hline
\end{tabular}

glacier, but rather is fed by groundwater and springs (Tom DeRoo, Peronal Communication, 2009). The upper drainage basin is $3.4 \%$ bedrock with $16.1 \%$ of the basin covered in vegetation. Steep unconsolidated and unvegetated slopes account for $46.3 \%$ of the upper basin. Sediment type in the upper basin is predominantly Rhododendron Formation and pyroclastic flow and debris flow deposits (Sherrod \& Scott, 1995). It received approximately $20 \mathrm{~cm}$ of rain in the November, $2006 \mathrm{storm}$ (NEXRAD, 2009). The overall azimuth of the upper drainage is $236^{\circ}$. The maximum elevation for the basin catchment area above the fan was calculated at 3,128 meters with a minimum of 770 meters. Basin height is 2,358 meters. Stream gradient for the upper drainage basin is approximately .25. . Melton's Ruggedness Number for this basin has been calculated at $R=0.40$. 


\section{POLALLIE CREEK DRAINAGE BASIN:}

Polallie Creek is located on the northeast side of the mountain as shown in Figure

45. The Polallie Creek drainage did not experience a debris flow as a result of the

November, 2006 storm. The investigation into the Polallie Basin included a field

based reconnaissance, sample collection and data processing.

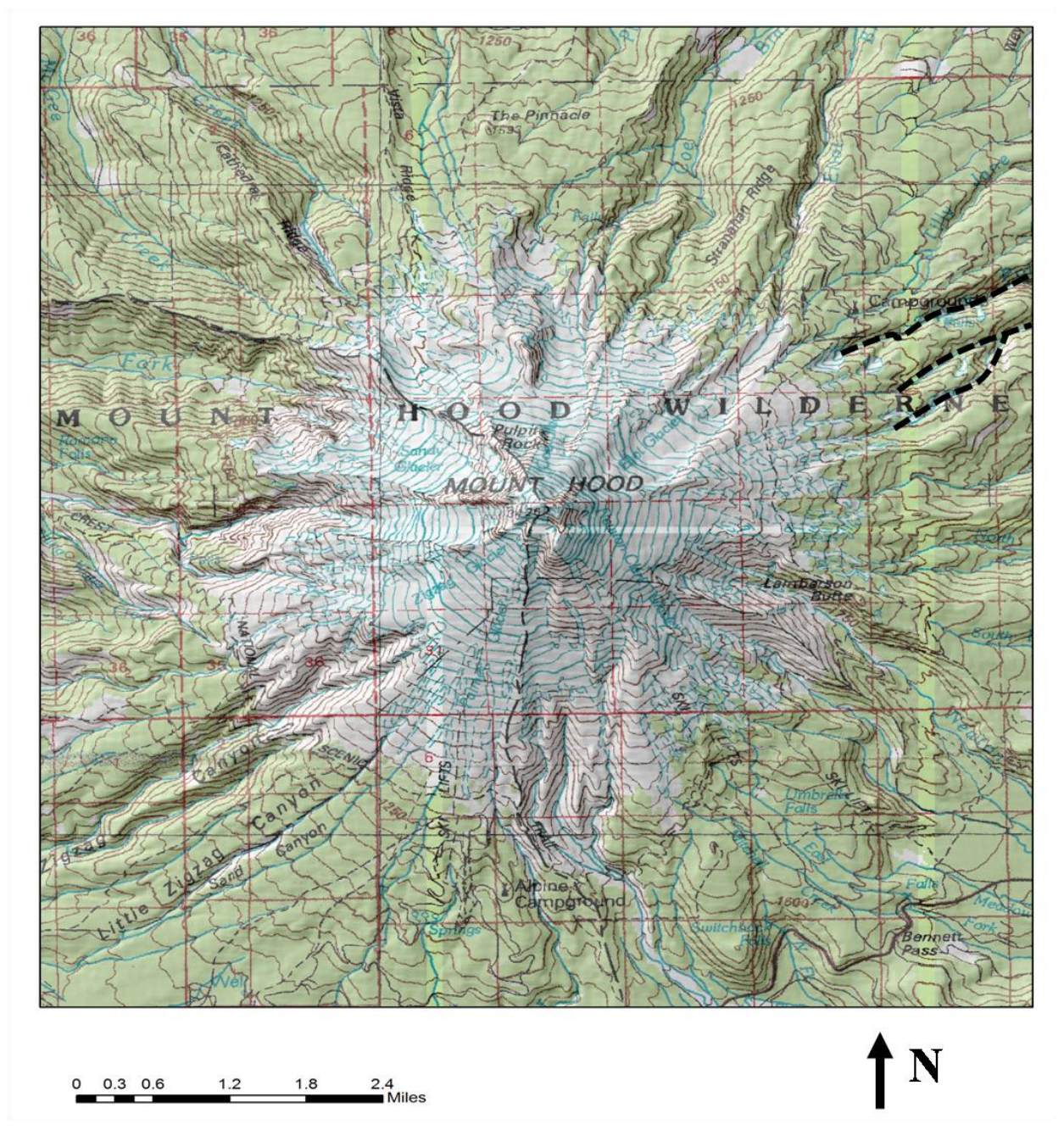

Figure 45. Polallie Creek shown in dashed black 


\section{Reconnaissance \& Sample Collection:}

\section{Initial Reconnaissance}

Highway 35 crosses the Polallie Creek on the east side of the mountain. No evidence of recent debris flow activity was noted at this point. Deposits had vegetation growing out of them, and vegetation was noted in or near the stream channel. There was no evidence of fresh boulder levees or recent debris flow deposits. Upstream from this point, into the headwaters of the Polallie Basin, vegetated slopes were observed as shown in Figure 46. No change in color was noted in the stream bed to indicate fresh debris flow deposits, and vegetation was seen in or near the channel. In the upper headwaters of the drainage several small or ongoing scree slope landslides were noted; however, a lack of debris flow deposits and features supports that there is no evidence of recent debris flow activity.

\section{Sample Collection}

Six samples were collected at headwaters of drainage, just above timberline (Figure 47). Samples were collected within alpine vegetated areas with ground hugging shrubbery.

\section{Data Processing:}

\section{Sieve Results}

Samples were sieved and averaged together as shown in 
Table 10. Material from the upper Polallie Creek drainage basin has an average bulk density of $1.5 \mathrm{~g} / \mathrm{cm}^{3}$. The average sample contained $47.2 \%$ gravel, $49.0 \%$ sand and $3.6 \%$ fine grained material. Of the sand, coarse grained material is in the clear majority with just over $67 \%$.

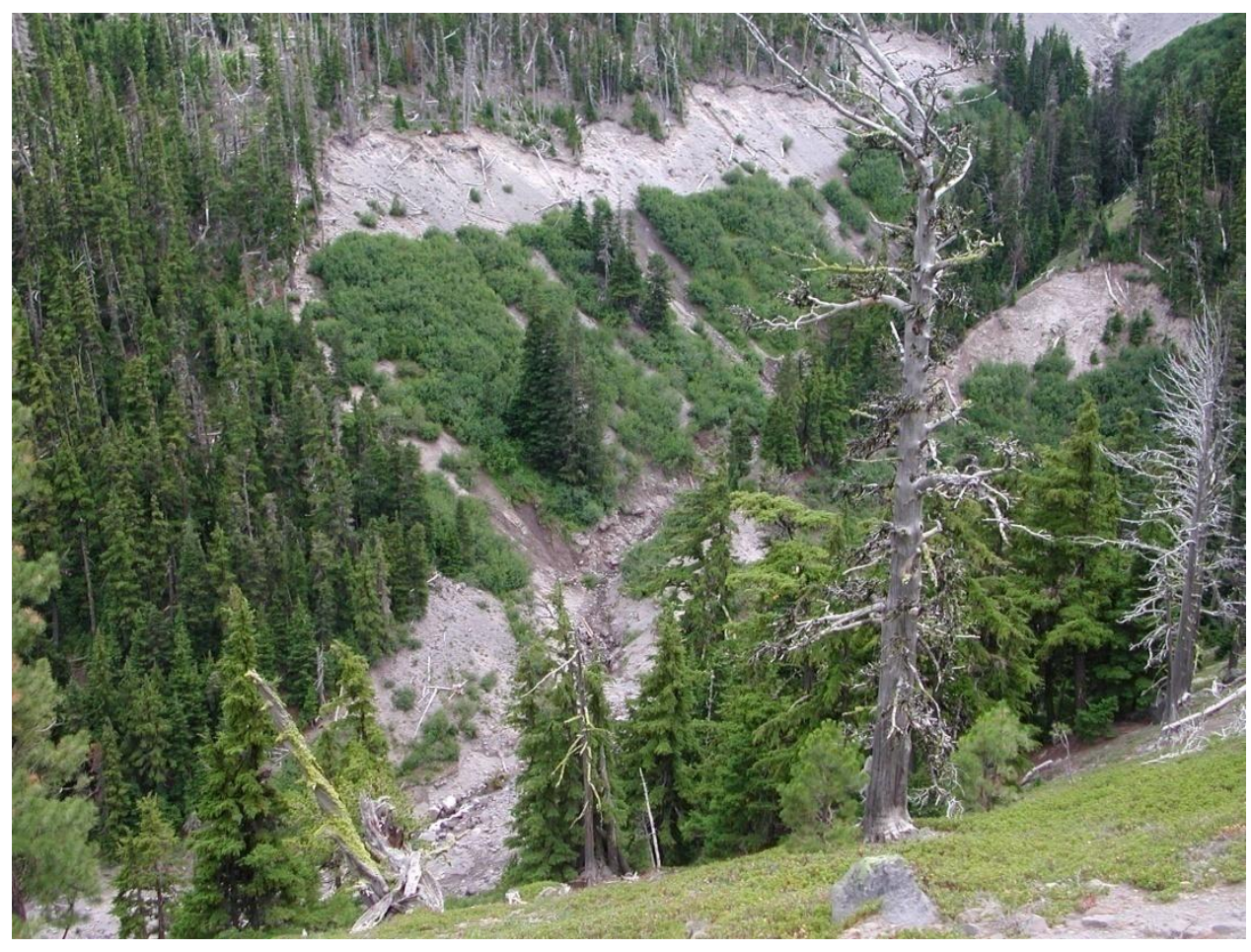

Figure 46. Polallie Creek vegetated slopes 


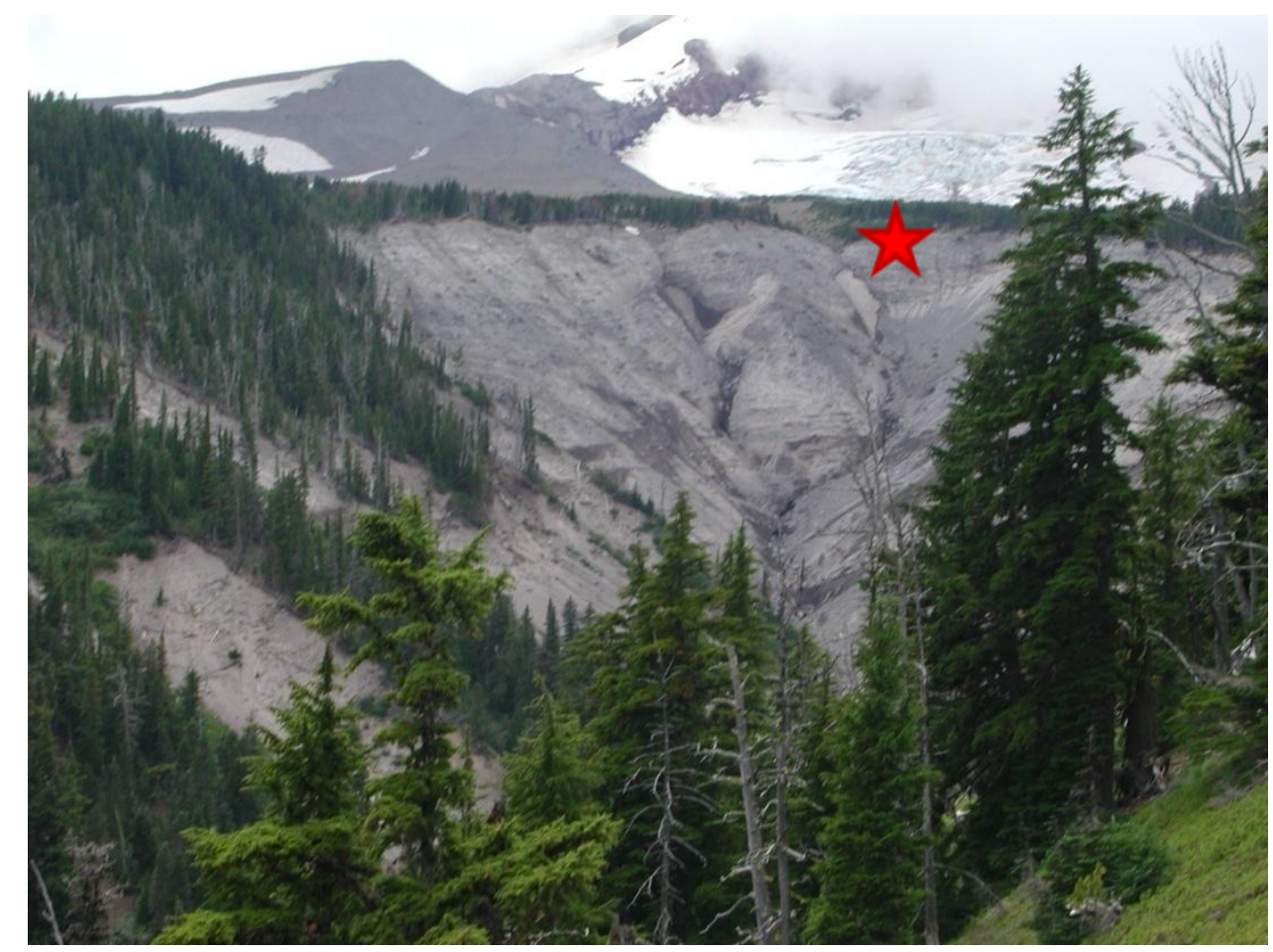

Figure 47. Polallie Creek sample collection site (UTM 0605298N, 5027373E)

Table 10. Polallie Creek sieve results

\begin{tabular}{|c|c|c|c|c|c|c|c|}
\hline \multirow{2}{*}{$\begin{array}{c}\text { Polallie } \\
\text { Creek } \\
\text { Sample \# }\end{array}$} & \multirow{2}{*}{$\begin{array}{c}\text { Bulk } \\
\text { Density } \\
\left(\mathrm{g} / \mathrm{cm}^{3}\right)\end{array}$} & \multirow[b]{2}{*}{$\begin{array}{l}\text { Gravel } \\
>2 \mathrm{~mm}\end{array}$} & \multirow{2}{*}{$\begin{array}{l}\text { Sand } \\
2 \mathrm{~mm}- \\
.063 \mathrm{~mm}\end{array}$} & \multirow{2}{*}{$\begin{array}{c}\text { Silt \& } \\
\text { Clay } \\
<.063 \mathrm{~mm}\end{array}$} & \multicolumn{3}{|c|}{ Sand } \\
\hline & & & & & $\begin{array}{c}\text { Coarse } \\
2 \mathrm{~mm}- \\
.25 \mathrm{~mm} \\
\end{array}$ & $\begin{array}{c}\text { Medium } \\
.25 \mathrm{~mm}- \\
.149 \mathrm{~mm}\end{array}$ & $\begin{array}{l}\text { Fine } \\
.149 \mathrm{~mm}- \\
.063 \mathrm{~mm}\end{array}$ \\
\hline 1 & 1.3 & $39.6 \%$ & $57.7 \%$ & $3.3 \%$ & $65.8 \%$ & $19.5 \%$ & $14.8 \%$ \\
\hline 2 & 1.5 & $22.7 \%$ & $66.9 \%$ & $8.6 \%$ & $60.7 \%$ & $22.7 \%$ & $16.6 \%$ \\
\hline 3 & 1.6 & $63.6 \%$ & $35.6 \%$ & $1.1 \%$ & $77.7 \%$ & $13.8 \%$ & $8.5 \%$ \\
\hline 4 & 1.4 & $63.0 \%$ & $34.1 \%$ & $2.8 \%$ & $63.4 \%$ & $18.4 \%$ & $18.2 \%$ \\
\hline 5 & 1.5 & $43.8 \%$ & $52.7 \%$ & $3.5 \%$ & $63.1 \%$ & $20.1 \%$ & $16.8 \%$ \\
\hline 6 & 1.7 & $50.5 \%$ & $47.2 \%$ & $2.2 \%$ & $75.1 \%$ & $14.1 \%$ & $10.8 \%$ \\
\hline Average & 1.5 & $47.2 \%$ & $49.0 \%$ & $3.6 \%$ & $67.6 \%$ & $18.1 \%$ & $14.3 \%$ \\
\hline Standard dev. & $16 \%$ & $15 \%$ & $\% 13$ & $3 \%$ & $7 \%$ & $4 \%$ & $4 \%$ \\
\hline
\end{tabular}

\section{Drainage Basin Attributes}

The total basin catchment area for the Polallie River is $13.1 \mathrm{~km}^{2}$ with an upper drainage basin area of $7.9 \mathrm{~km}^{2}$. This basin does not have direct connection to a 
glacier but rather is fed by groundwater and springs (Tom DeRoo, Peronal Communication, 2009). The upper drainage basin is $0.9 \%$ bedrock with $65.9 \%$ of the upper basin covered in vegetation. Steep unconsolidated and unvegetated slopes account for $5.7 \%$ of the upper basin. Sediment type in the upper basin is predominantly pyroclastic flow and debris flow deposits (Sherrod \& Scott, 1995). It received approximately 15 to $20 \mathrm{~cm}$ of rain in the November, 2006 storm (NEXRAD, 2009). The overall azimuth of the upper drainage is $60^{\circ}$. The maximum elevation for the basin catchment area above the fan was calculated at 2,584 meter with a minimum of 917 meters. Basin height is 1,667 meters. Stream gradient for the upper drainage basin is approximately .17. Melton's Ruggedness Number for this basin has been calculated at $R=0.46$.

\section{COE CREEK DRAINAGE BASIN:}

Coe Creek is located on the north side of the mountain as shown in Figure 48. The Coe Creek drainage did not experience a debris flow as a result of the November, 2006 storm. The investigation into the Coe Creek Basin included a field based reconnaissance, sample collection and data processing.

\section{Reconnaissance \& Sample Collection:}

\section{Initial Reconnaissance}

Laurance Lake Road crosses Coe Creek just above the fan of the Coe Creek drainage. There was no evidence of debris flow activity at this point. Vegetation 


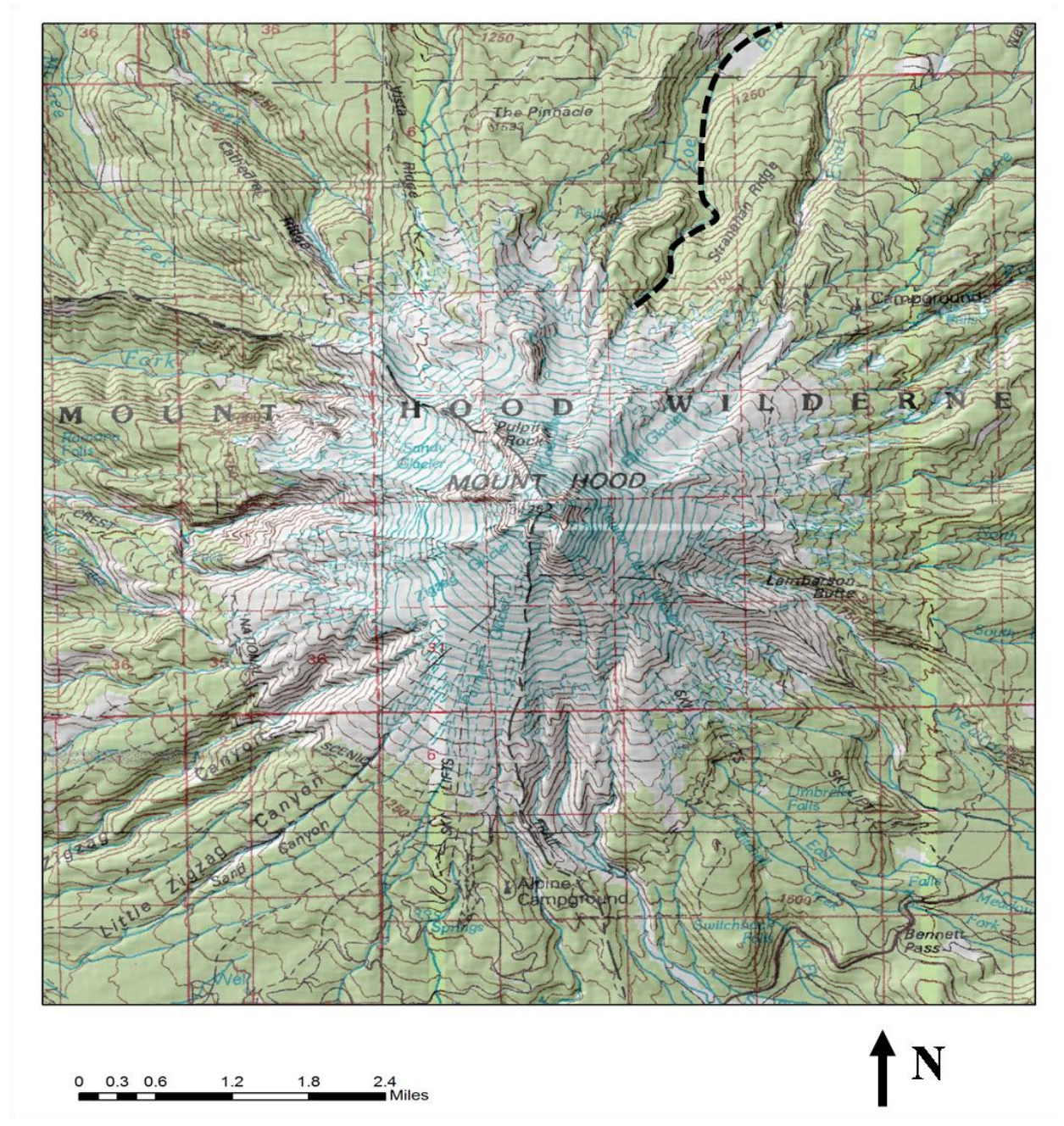

Figure 48. Coe Creek shown in dashed black

is noted near the edge of the stream. No evidence of fresh levees or recent erosion

is present as shown in Figure 49. There was no damage noted to irrigation

equipment in the channel. Where the Timberline Trail crosses the drainage, and

below the falls downstream from the Timberline Trail crossing, there are large

boulders and a lack of vegetation in the stream channel. However, deposits

downstream have shrubs growing out of them. Lightweight woody debris is present

in the channel, but no mud coatings were noted. Tree trunks with bark ripped off 
also indicated no mud coatings. Large landslide scarps were observed in the Coe headwaters which contained protruding boulders. The sidewall boulders could possibly be a source area for the boulders present in the channel. Some landslide deposits are present at the base of sidewall slopes. Fresh slides begin midway up the slope on the east side of canyon wall. The boulder field continues up the drainage as far as visible and is comprised of poorly sorted, bouldery, mostly clast supported deposits. There is no evidence for boulder levees or matrix supported debris flow deposits.

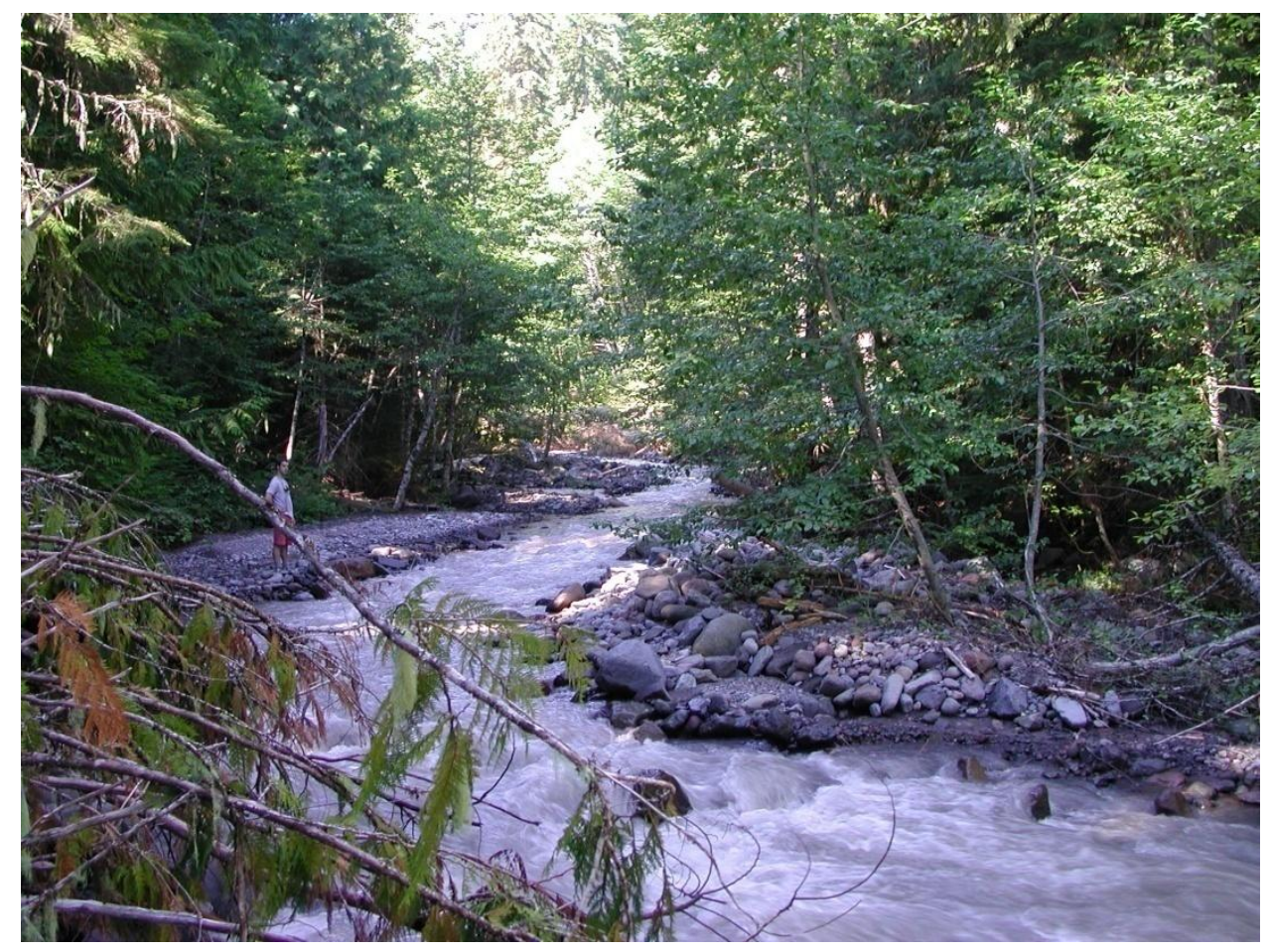

Figure 49. Coe Creek above Laurance Lake Road. 


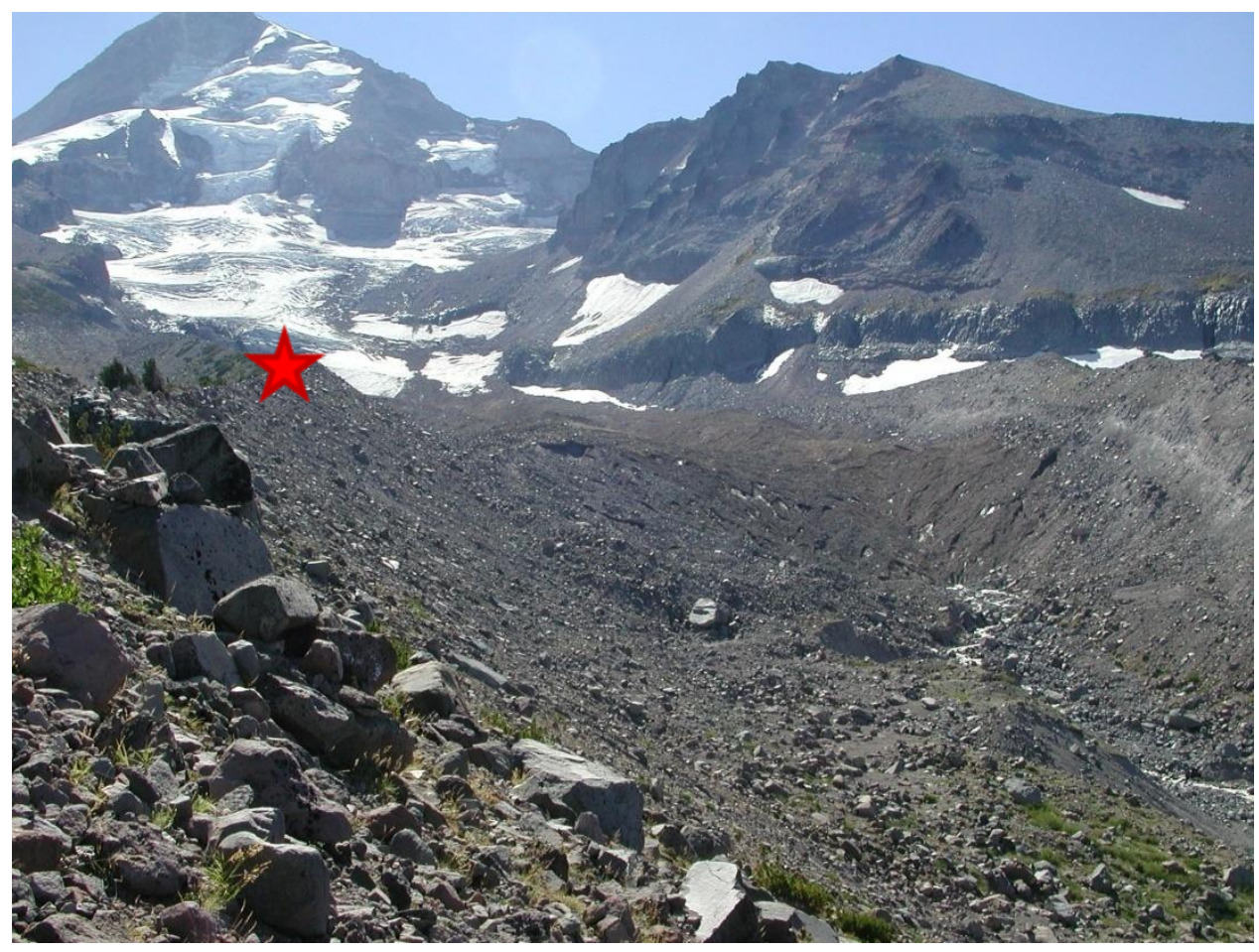

Figure 50. Coe Creek sample collection site (UTM 0602544N, 5028643E)

Lower moraine walls seem less steep and more vegetated than those observed in the Eliot Creek Drainage. A landslide scarp is visible above the point in the drainage where the moraine sidewalls constrict; however, the talus slope has filled in indicating that landslide activity is not recent. These observations combined with plenty of vegetation near the channel indicate that there is no evidence for a recent debris flow in Coe Creek.

\section{Sample Collection}

Six samples were collected from the morainal material, at the top of moraine, above the timberline and slightly above the lateral moraine constriction point. The sample collection site was unvegetated (Figure 50). 


\section{Data Processing:}

\section{Sieve Results}

Samples were sieved and averaged together as shown below in Table 11.

Material from the upper Coe Creek drainage basin has an average bulk density of 1.7 $\mathrm{g} / \mathrm{cm}^{3}$. The average sample contains $47.8 \%$ gravel, $45.3 \%$ sand and $6.7 \%$ fine grained material. Of the sand, coarse grained material is in the clear majority with about $54 \%$.

\section{Drainage Basin Attributes}

The total basin catchment area for the Coe Creek drainage is $18.5 \mathrm{~km}^{2}$ with an upper drainage basin area of $2.9 \mathrm{~km}^{2}$. This basin is directly connected to the Coe Glacier which has an area of approximately 1,240,000 m² (Jackson \& Fountain, 2007; Jackson K. M., 2007). The upper drainage basin is $9.2 \%$ bedrock with $25.2 \%$ of the upper basin covered in vegetation.

Table 11. Coe Creek sieve results

\begin{tabular}{|c|c|c|c|c|c|c|c|}
\hline \multirow[b]{2}{*}{$\begin{array}{l}\text { Coe Creek } \\
\text { Sample \# }\end{array}$} & \multirow{2}{*}{$\begin{array}{c}\text { Bulk } \\
\text { Density } \\
\left(\mathrm{g} / \mathrm{cm}^{3}\right)\end{array}$} & \multirow[b]{2}{*}{$\begin{array}{l}\text { Gravel } \\
>2 \mathrm{~mm}\end{array}$} & \multirow[b]{2}{*}{$\begin{array}{l}\text { Sand } \\
2 \mathrm{~mm}- \\
.063 \mathrm{~mm}\end{array}$} & \multirow{2}{*}{$\begin{array}{c}\text { Silt \& } \\
\text { Clay } \\
<.063 \mathrm{~mm}\end{array}$} & \multicolumn{3}{|c|}{ Sand } \\
\hline & & & & & $\begin{array}{c}\text { Coarse } \\
2 \mathrm{~mm}- \\
.25 \mathrm{~mm} \\
\end{array}$ & $\begin{array}{c}\text { Medium } \\
.25 \mathrm{~mm}- \\
.149 \mathrm{~mm} \\
\end{array}$ & $\begin{array}{c}\text { Fine } \\
.149 \mathrm{~mm}- \\
.063 \mathrm{~mm} \\
\end{array}$ \\
\hline 1 & 1.8 & $45.6 \%$ & $50.5 \%$ & $3.7 \%$ & $71.0 \%$ & $16.3 \%$ & $12.7 \%$ \\
\hline 2 & 1.9 & $59.4 \%$ & $38.5 \%$ & $2.0 \%$ & $75.8 \%$ & $13.3 \%$ & $10.9 \%$ \\
\hline 3 & 1.7 & $66.7 \%$ & $28.1 \%$ & $4.9 \%$ & $41.5 \%$ & $18.6 \%$ & $39.9 \%$ \\
\hline 4 & 1.3 & $11.2 \%$ & $74.8 \%$ & $13.6 \%$ & $55.3 \%$ & $17.7 \%$ & $26.9 \%$ \\
\hline 5 & 1.9 & $61.1 \%$ & $30.1 \%$ & $8.6 \%$ & $49.4 \%$ & $19.2 \%$ & $31.4 \%$ \\
\hline 6 & 1.3 & $42.9 \%$ & $49.6 \%$ & $7.5 \%$ & $32.2 \%$ & $30.3 \%$ & $37.4 \%$ \\
\hline Average & 1.7 & $47.8 \%$ & $45.3 \%$ & $6.7 \%$ & $54.2 \%$ & $19.2 \%$ & $26.5 \%$ \\
\hline Standard dev. & $28 \%$ & $20 \%$ & $17 \%$ & $4 \%$ & $17 \%$ & $6 \%$ & $12 \%$ \\
\hline
\end{tabular}


Steep unconsolidated and unvegetated slopes account for $9.9 \%$ of the upper basin.

Sediment type in the upper basin is predominantly till of neo-glacial age (Sherrod \& Scott, 1995 ) and received approximately $20 \mathrm{~cm}$ of rain in the November, 2006 storm (NEXRAD, 2009). The overall azimuth of the upper drainage is $17^{\circ}$. The maximum elevation for the basin catchment area above the fan was calculated at 3,068 meters with a minimum of 826 meters. Basin height is 2,242 meters. Stream gradient for the upper drainage basin is approximately .25. Melton's Ruggedness Number for this basin has been calculated at $\mathrm{R}=$ 0.52 .

\section{MUDDY FORK DRAINAGE BASIN:}

The Muddy Fork of the Sandy River is located on the west side of the mountain as shown in Figure 51. The Muddy Fork Drainage did not experience a debris flow as a result of the November, 2006 storm. The investigation into the Muddy Fork Basin included a field based reconnaissance, sample collection and data processing.

\section{Sample Collection}

Six samples were collected from the pyroclastic fill derived soil on a natural slope adjacent to the active river channel. The sample collection site was located just below the rock source area for the 2002 debris avalanche (Figure 52). This source area was below the timberline; however, it was chosen for its proximity to the previous debris avalanche initiation zone. 


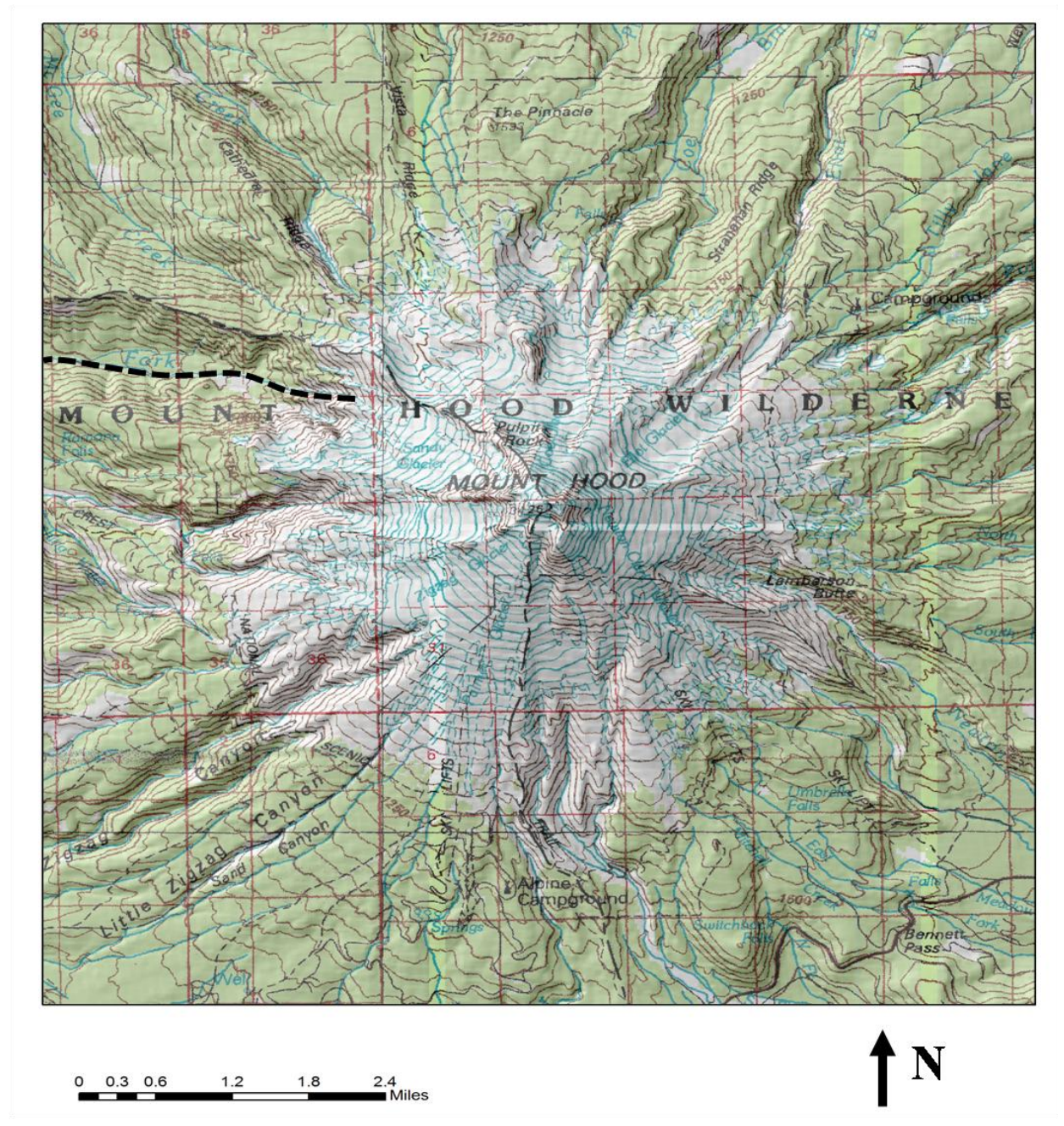

Figure 51. Muddy Fork of the Sandy River shown in dashed black

\section{Data Processing:}

\section{Sieve Results}

Samples collected were sieved and averaged as shown in Table 12. Material from the upper Muddy Fork drainage basin has an average bulk density of $1.6 \mathrm{~g} / \mathrm{cm}^{3}$. The average sample has $48.4 \%$ gravel, $49.1 \%$ sand, and $2.0 \%$ fine grained material. Of the sand, coarse grained material is in the clear majority with almost $87 \%$. 


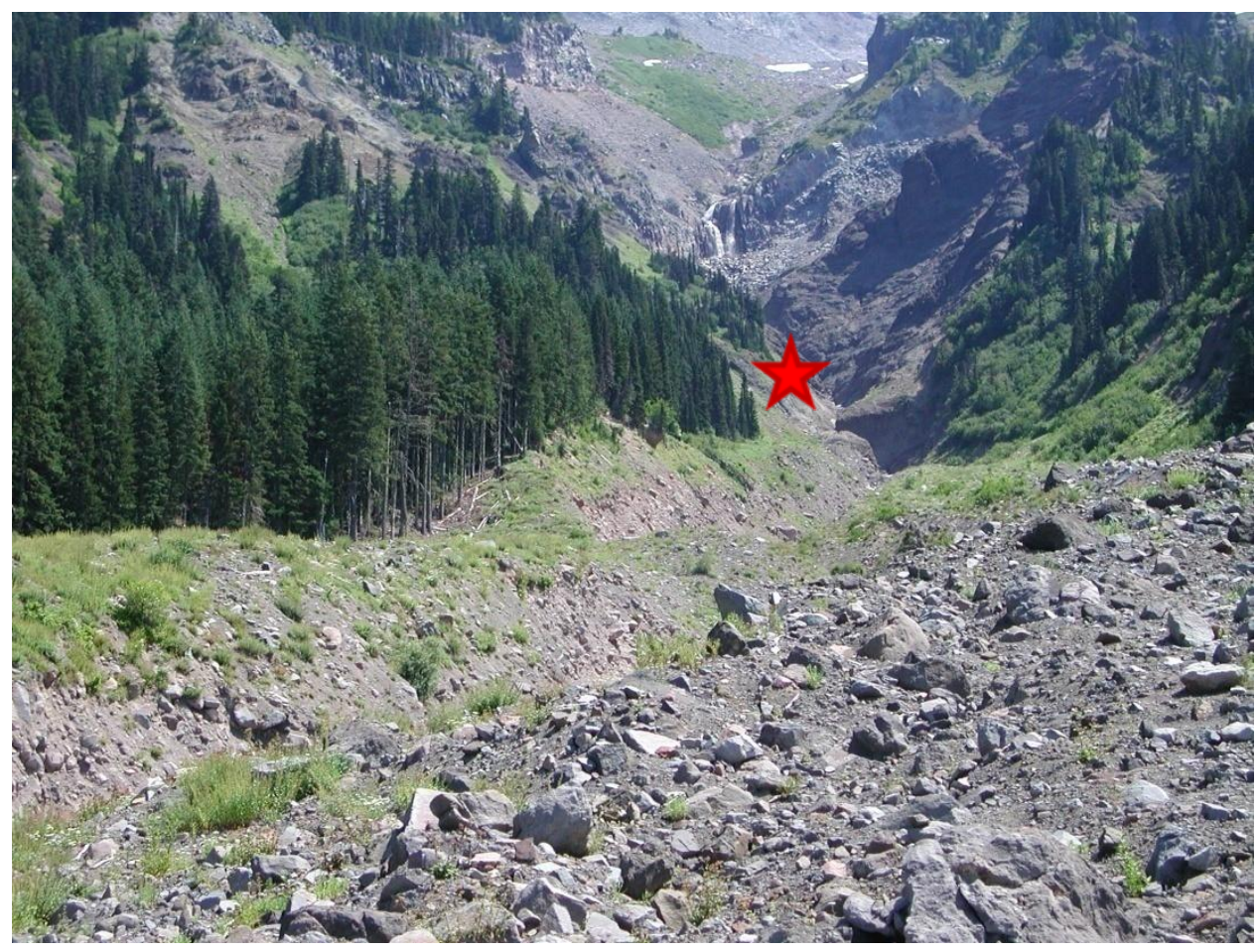

Figure 52. Muddy Fork sample collection site (UTM 0598762N, 5027046E)

\section{Drainage Basin Attributes}

The total basin catchment area for the Muddy Fork of the Sandy River is $11,8 \mathrm{~km}^{2}$ with an upper drainage basin area of $5.4 \mathrm{~km}^{2}$. This basin is directly connected to the Sandy Glacier which has an area of approximately 960,000 m² (Jackson K. M., 2007; Jackson \& Fountain, 2007). The upper drainage basin is $27.0 \%$ bedrock with $32.4 \%$ of the upper basin covered in vegetation. Steep unconsolidated and unvegetated slopes account for $12.0 \%$ of the upper basin. Sediment type in the upper basin is predominantly neoglacial till and pyroclastic flow and debris flow deposits (Sherrod \& Scott, 1995). It received approximately $36 \mathrm{~cm}$ of rain in the November, $2006 \mathrm{storm}$ (NEXRAD, 2009). 
Table 12. Muddy Fork sieve results

\begin{tabular}{|c|r|r|r|r|r|r|r|}
\hline \multirow{2}{*}{$\begin{array}{c}\text { Muddy Fork } \\
\text { Sample \# }\end{array}$} & $\begin{array}{c}\text { Bulk } \\
\text { Density } \\
\left(\mathbf{g} / \mathbf{c m}^{\mathbf{3}} \mathbf{)}\right.\end{array}$ & $\begin{array}{c}\text { Gravel } \\
>2 \mathrm{~mm}\end{array}$ & $\begin{array}{c}\text { Sand } \\
2 \mathrm{~mm}- \\
.063 \mathrm{~mm}\end{array}$ & $\begin{array}{c}\text { Silt \& } \\
\text { Clay } \\
<.063 \mathrm{~mm}\end{array}$ & $\begin{array}{c}\text { Coarse } \\
2 \mathrm{~mm}-\end{array}$ & $\begin{array}{c}\text { Medium } \\
.25 \mathrm{~mm}-\end{array}$ & $\begin{array}{c}\text { Fine } \\
.149 \mathrm{~mm}-\end{array}$ \\
\hline $\mathbf{1}$ & 1.7 & $50.0 \%$ & $46.6 \%$ & $3.3 \%$ & $83.4 \%$ & $7.4 \%$ & $9.2 \%$ \\
$\mathbf{2}$ & 1.6 & $48.8 \%$ & $48.7 \%$ & $1.9 \%$ & $87.4 \%$ & $6.5 \%$ & $6.2 \%$ \\
$\mathbf{3}$ & 1.5 & $45.5 \%$ & $51.2 \%$ & $2.6 \%$ & $84.8 \%$ & $8.0 \%$ & $7.2 \%$ \\
$\mathbf{4}$ & 1.7 & $46.3 \%$ & $52.5 \%$ & $0.8 \%$ & $91.5 \%$ & $5.4 \%$ & $3.2 \%$ \\
$\mathbf{5}$ & 1.6 & $48.4 \%$ & $49.5 \%$ & $2.0 \%$ & $88.4 \%$ & $5.8 \%$ & $5.9 \%$ \\
$\mathbf{6}$ & 1.6 & $51.4 \%$ & $46.0 \%$ & $1.7 \%$ & $85.8 \%$ & $6.5 \%$ & $7.7 \%$ \\
\hline Average & 1.6 & $48.4 \%$ & $49.1 \%$ & $2.0 \%$ & $86.9 \%$ & $6.6 \%$ & $6.5 \%$ \\
\hline Standard dev. & 0.11 & 0.02 & 0.03 & 0.01 & 0.03 & 0.01 & 0.02 \\
\hline
\end{tabular}

The overall azimuth of the upper drainage is $300^{\circ}$. The maximum elevation for the basin catchment area above the fan was calculated at 3,290 meters with a minimum of 1,250 meters. Basin height is 2,040 meters. Stream gradient for the upper drainage basin is approximately .30. Melton's Ruggedness Number for this basin has been calculated at $\mathrm{R}=.70$.

\section{SUMMARY}

As a result of the November, 2006 storm, seven of the eleven main drainages on Mount Hood had debris flows. Four of the debris flows were landslide initiated with evidence of undercutting of the slope in the streambed below the slide, three were headless. Debris flow initiation zone material, smaller than cobble sized, was predominantly granular with a very low percentage of fines. Initiation zone parent material (Table 13) did not show a strong connection to the occurrence of debris flows. 
Table 13. Initiation zone parent material by drainage

\begin{tabular}{|c|c|}
\hline Drainage & Parent Material \\
\hline Eliot & Neoglacial Till \\
\hline Sandy & Pyroclastic \& Debris Flow \\
\hline White & Pyroclastic \& Debris Flow \\
\hline Newton & Neoglacial Till \\
\hline Clark & Lava Flows \& Neoglacial Till \\
\hline Salmon & Pyroclastic \& Debris Flow \\
\hline Ladd & Debris Flow \& Neoglacial Till \\
\hline Zigzag & Pyroclastic \& Debris Flow \\
\hline Polallie & Pyroclastic \& Debris Flow \\
\hline Coe & Neoglacial Till \\
\hline Muddy Fork & Debris Flow \& Neoglacial Till \\
\hline
\end{tabular}

Debris flows initiated on all sides of Mount Hood between elevations 1,760 to 2,020 meters with an average elevation of 1,860 meters (Figure 53 ). A summary of drainage basin characteristics is provided in Table 14. The Eliot Creek Debris Flow and Newton Creek were the largest based on distance traveled followed closely by

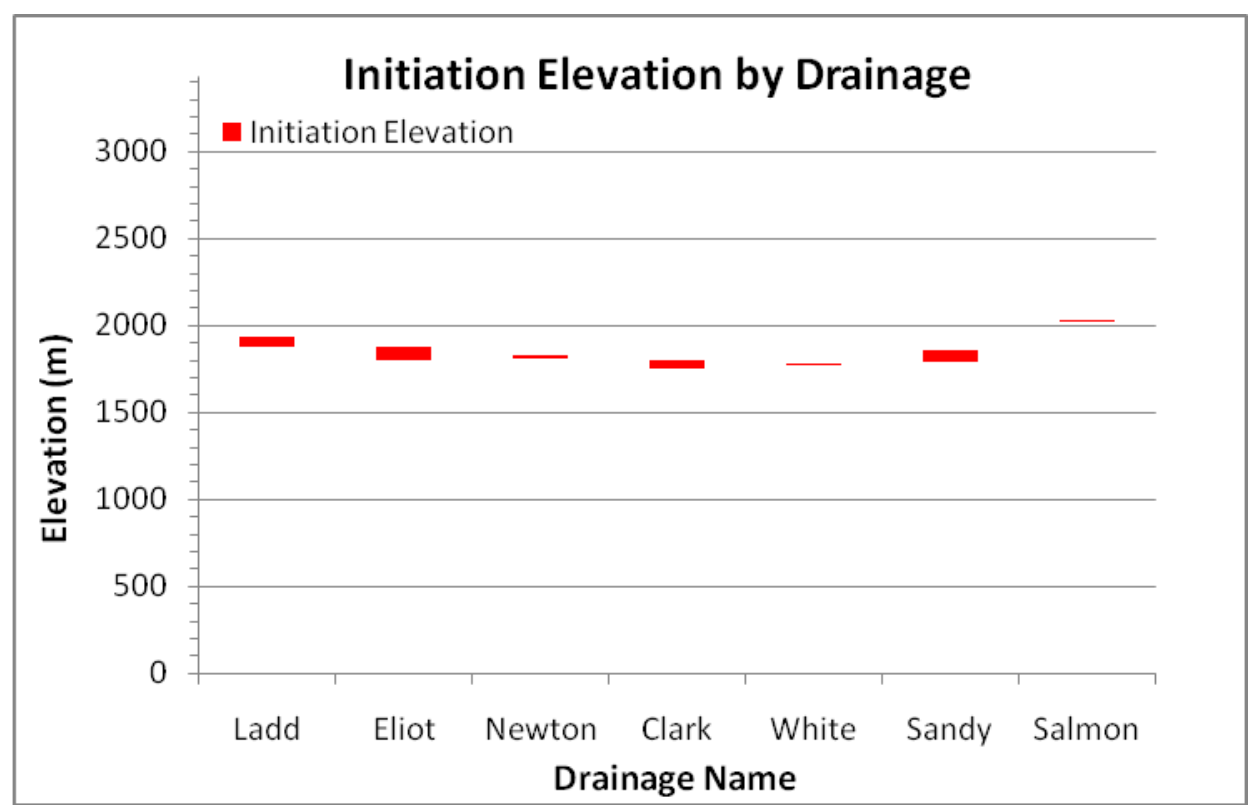

Figure 53. Initiation elevation by drainage (Thickness of line refers to elevation range) 
Table 14. Summary chart of drainage basin characteristics

\begin{tabular}{|c|c|c|c|c|c|c|}
\hline Drainage & $\begin{array}{l}\text { Debris } \\
\text { Flow }\end{array}$ & Rainfall (cm) & $\begin{array}{l}\text { Percent } \\
\text { Bedrock }\end{array}$ & $\begin{array}{l}\text { Percent } \\
\text { Vegetation }\end{array}$ & $\begin{array}{l}\text { Percent Steep } \\
\text { Slopes }\end{array}$ & Glacier Area $\left(m^{2}\right)$ \\
\hline Eliot & Yes & 20 & 3 & 4 & 18 & $1,640,000$ \\
\hline Sandy & Yes & 36 & 5 & 8 & 30 & 769,000 \\
\hline White & Yes & 18 & 3 & 2 & 42 & 407,000 \\
\hline Newton & Yes & 15 & 7 & 24 & 23 & $1,390,000$ \\
\hline Clark & Yes & 15 & 8 & 27 & 27 & $1,390,000$ \\
\hline Salmon & Yes & 15 & 0 & 4 & 9 & 130,000 \\
\hline Ladd & Yes & 36 & 12 & 14 & 11 & 670,000 \\
\hline Zigzag & No & 20 & 3 & 16 & 46 & 0 \\
\hline Polallie & No & 18 & 1 & 66 & 6 & 0 \\
\hline Coe & No & 20 & 9 & 25 & 10 & $1,240,000$ \\
\hline Muddy & No & 36 & 27 & 32 & 12 & 960,000 \\
\hline Drainage & Gradient & $\begin{array}{l}\text { Connection } \\
\text { to Glacier }\end{array}$ & $\begin{array}{l}\text { Azimuth } \\
\text { (degrees) }\end{array}$ & $\begin{array}{l}\text { Ruggedness } \\
\text { Number }\end{array}$ & $\begin{array}{l}\text { Upper Drainage } \\
\text { Basin Area }\left(\mathbf{k m}^{2}\right)\end{array}$ & $\begin{array}{c}\text { Area Above } \\
\text { Initiation Zone }\left(\mathrm{km}^{2}\right)\end{array}$ \\
\hline Eliot & 0.23 & Yes & 41 & 0.85 & 3.3 & 3.0 \\
\hline Sandy & 0.27 & Yes & 260 & 0.44 & 3.1 & 1.7 \\
\hline White & 0.18 & Yes & 175 & 0.75 & 6.5 & 1.8 \\
\hline Newton & 0.15 & Yes & 122 & 0.72 & 5.3 & 1.2 \\
\hline Clark & 0.16 & Yes & 132 & 0.68 & 3.9 & 0.9 \\
\hline Salmon & 0.23 & Yes & 187 & 0.43 & 1.4 & 0.6 \\
\hline Ladd & 0.19 & Yes & 330 & 0.33 & 2.3 & 1.4 \\
\hline Zigzag & 0.25 & No & 236 & 0.40 & 3.1 & \\
\hline Polallie & 0.17 & No & 60 & 0.46 & 7.9 & \\
\hline Coe & 0.25 & Yes & 17 & 0.53 & 2.9 & \\
\hline Muddy & 0.3 & Yes & 300 & 0.70 & 5.4 & \\
\hline
\end{tabular}

the White River and Sandy River debris flows. Debris flows in Ladd Creek, Clark Creek and the west fork of the Salmon River were the smallest in the November, 2006 storm event (Figure 54). Drainages that produced debris flows appear to be transport limited or able to produce debris flows given the right climactic trigger. Based on historic records and an evaluation of Melton's Ruggedness number, all of the eleven primary drainages seem capable of producing debris flows. 


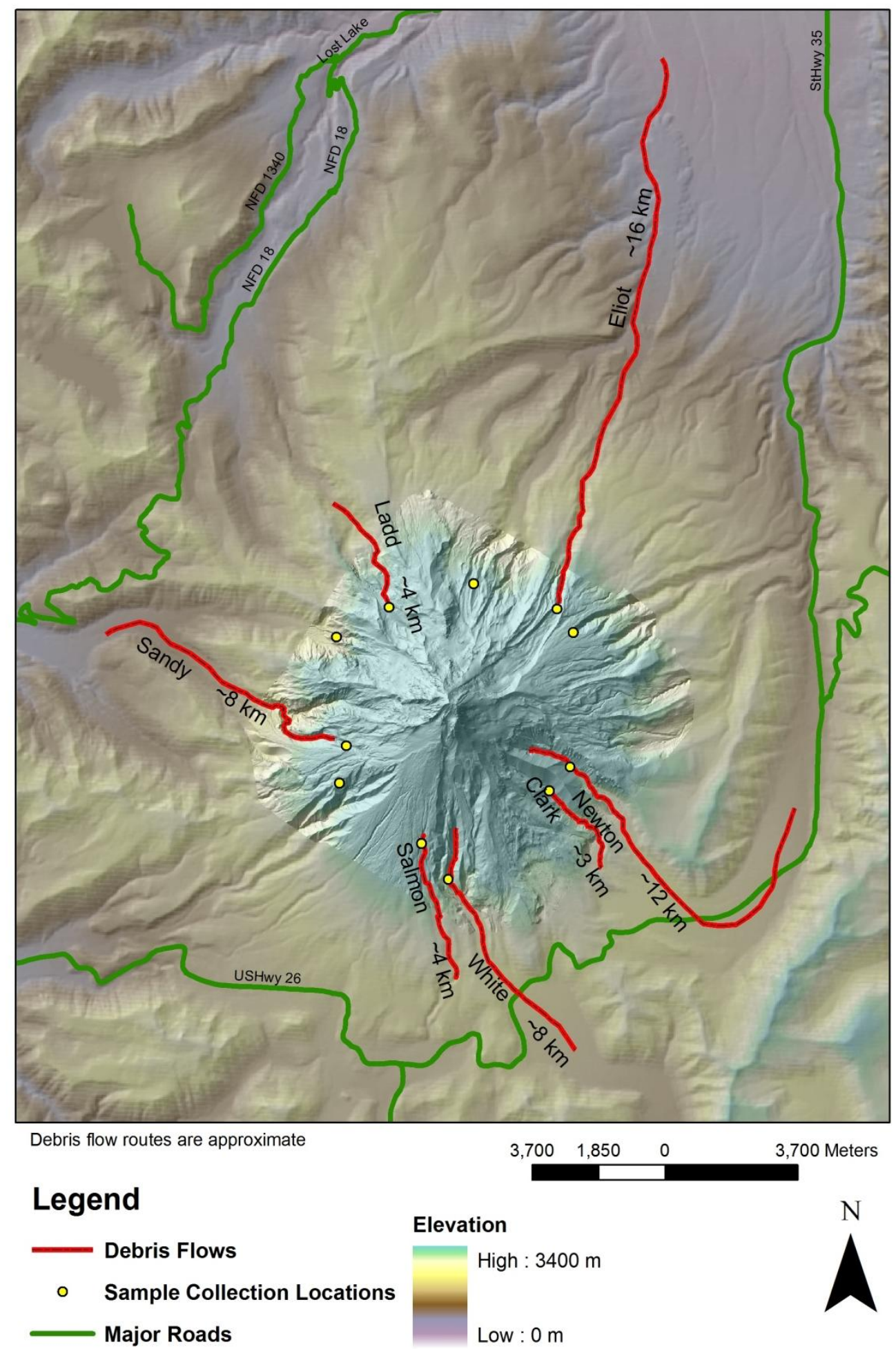

Figure 54. Debris flow locations and sizes 


\section{RAINFALL DATA}

Both NWAC rainfall data and NEXRAD data indicates that the November, 2006 storm had high rainfall at the upper elevations. A map of the precipitation total for the NEXRAD storm data is shown in Figure 55. NWAC rainfall data reports between 33 to 38 percent higher than that indicated by NEXRAD. Due to this divergence, NEXRAD data should be considered minimum values especially for the upper elevations.

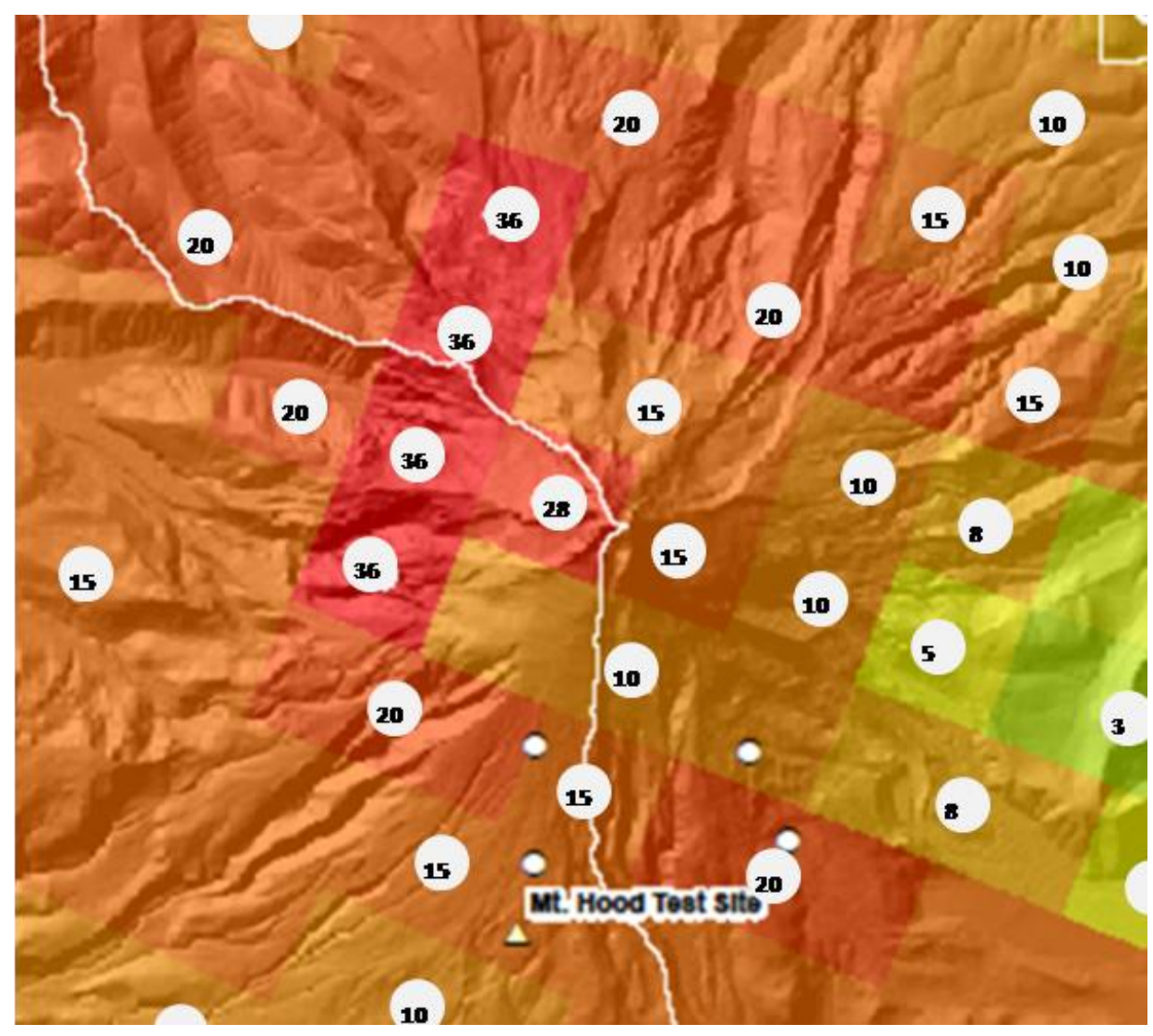

Figure 55. Close-up of NEXRAD Storm data showing total rainfall in $\mathrm{cm}$ (written communication, Todd Parker, USFS 2008) 
Lower elevation data also showed that the storm was unusual for that time of year at those elevations. Between 2000 and 2008, no other storms had equal or greater rainfall amounts than the November, 2006 storm as recorded by SNOWTEL at the lower elevations. In general, minimum storm totals provided by NEXRAD data were equal to or less than measured precipitation at the lower elevation SNOTEL sites. Therefore, due to NEXRAD underestimation when compared to both NWAC and SNOWTEL data, it can be inferred that total storm precipitation accumulation at the higher elevations was actually significantly higher than the minimums reported.

SNOWTEL sites did not indicate significant antecedent moisture conditions prior to November 3,2006 . The average cumulative precipitation in the 10 days leading up to the storm was less than $4 \mathrm{~cm}$. The average largest amount of daily rainfall in the 10 days leading up to the storm was $2.3 \mathrm{~cm}$. The storm data went for six days, November 3-8. Precipitation data from the three SNOTEL sites closest to Mount Hood is shown in Table 15. SNOWTEL site locations are shown in Figure 56.

Table 15. SNOWTEL daily precipitation data for November 3-8

\begin{tabular}{|c|c|c|c|}
\hline $\begin{array}{c}\text { Date } \\
\text { (November 2006) }\end{array}$ & $\begin{array}{c}\text { Blazed Alder Station } \\
\text { Precipitation } \mathbf{( c m )}\end{array}$ & $\begin{array}{c}\text { Mount Hood Station } \\
\text { Precipitation } \mathbf{( c m})\end{array}$ & $\begin{array}{c}\text { Red Hill Station } \\
\text { Precipitation } \mathbf{( c m})\end{array}$ \\
\hline $\mathbf{3}$ & 5.1 & 2.0 & 3.0 \\
$\mathbf{4}$ & 5.8 & 3.0 & 3.3 \\
$\mathbf{5}$ & 6.4 & 4.1 & 5.1 \\
$\mathbf{6}$ & 10.4 & 4.8 & 5.6 \\
$\mathbf{7}$ & 14.7 & 7.1 & 13.0 \\
$\mathbf{8}$ & 16.8 & 9.1 & 12.4 \\
\hline Total Precipitation & $\mathbf{5 9 . 2}$ & $\mathbf{3 0 . 2}$ & $\mathbf{4 2 . 4}$ \\
\hline
\end{tabular}




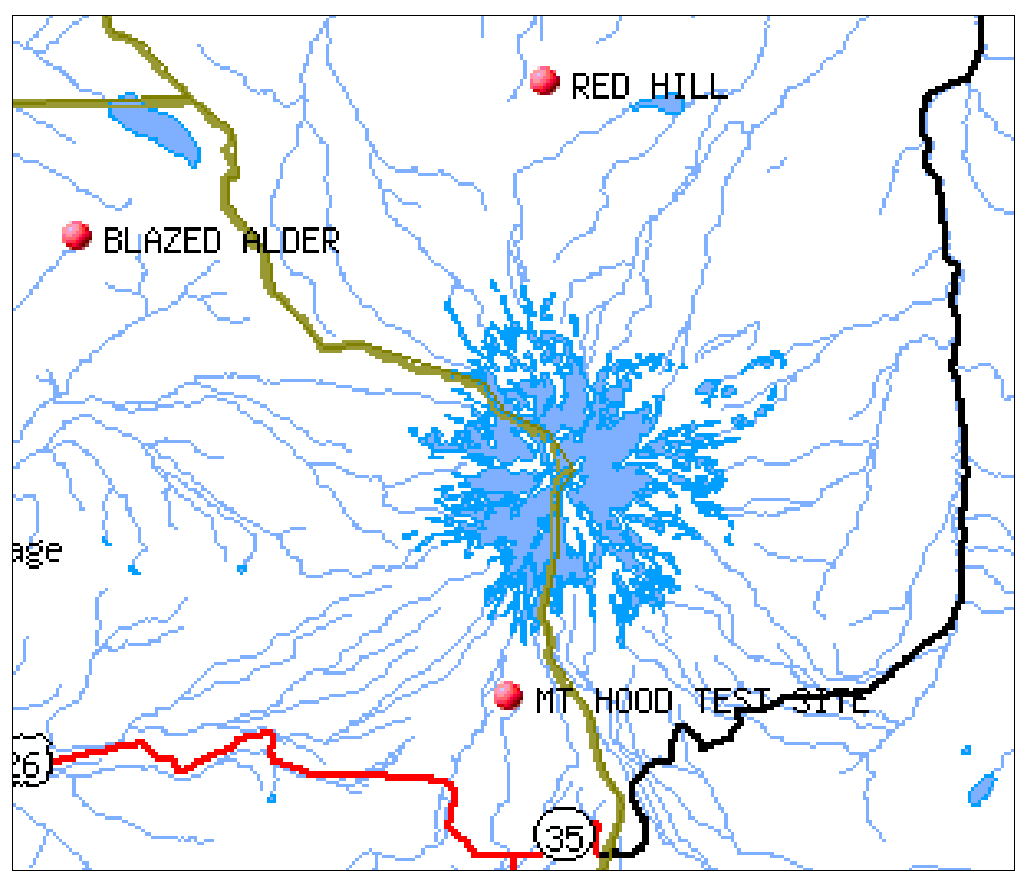

Figure 56. SNOWTEL sites near Mount Hood (www.or.nrcs.usda.gov/snow/maps/oregon sitemap.html)

NWAC data indicated about $30 \mathrm{~cm}$ of residual snowpack from the previous year in the Timberline (elevation $1830 \mathrm{~m}$ ) and Mount Hood Meadows (elevation 1,600 m) ski areas when the storm hit. The snowpack experienced rapid melting which coincided with a steady increase in daily rainfall totals. On November 6, when news reports gave the first evidence of debris flow occurrence through a series of road out reports, daily cumulative rainfall, shown as daily cumulative precipitation in Figure $57 \&$ Figure 58, was between 5 and $6 \mathrm{~cm}$ while the collective storm rainfall was between 14 and $18.5 \mathrm{~cm}$. This rainfall coincided with a collective snow melt of 25 to $30 \mathrm{~cm}$ in these areas (Figure 57 \& Figure 58). This suggests that the combination of moderate to heavy rainfall with large amounts of rapid snowmelt assisted in creating high stream flow in the upper elevations. High stream flow can undercut the banks in 
sensitive areas, causing landslides which can transform into debris flows. The NWAC does not have precipitation gauges in all drainages but it can be inferred that the pattern of rapid snowmelt coinciding with heavy rainfall is not limited to these areas.

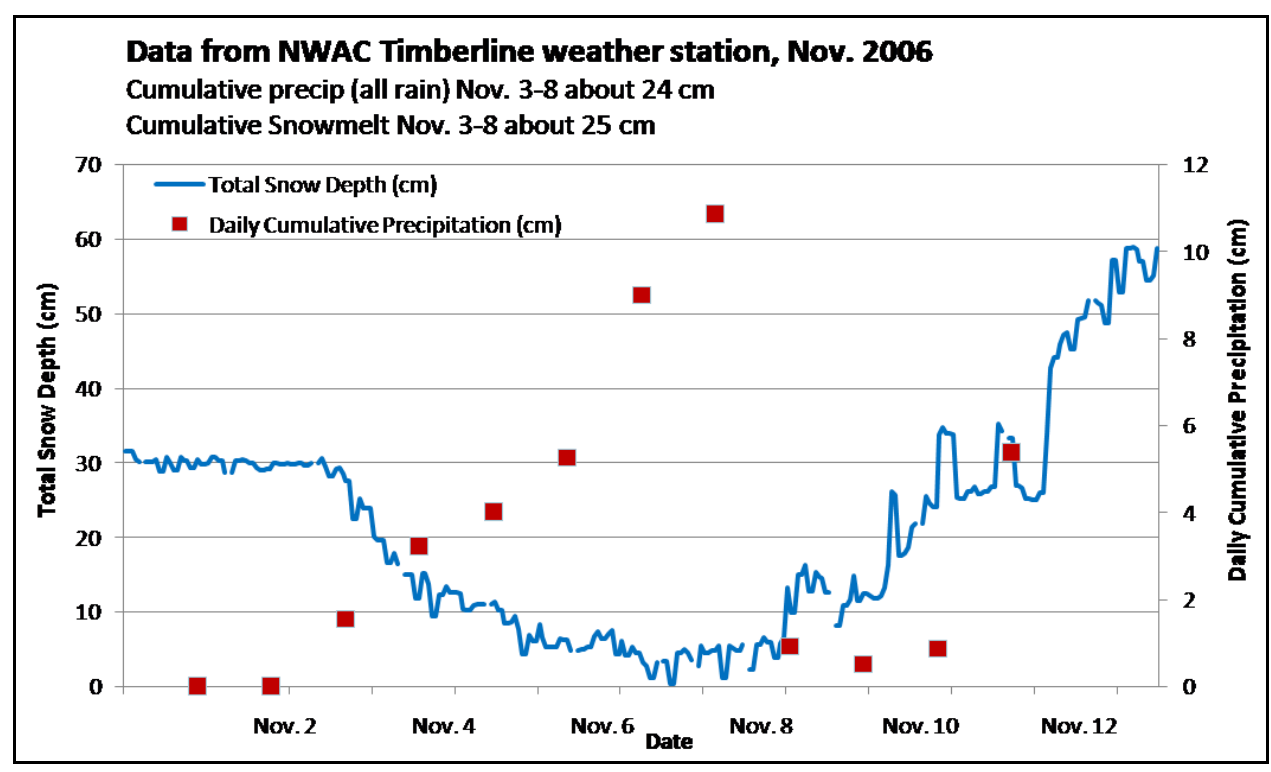

Figure 57. NWAC Timberline ski area data

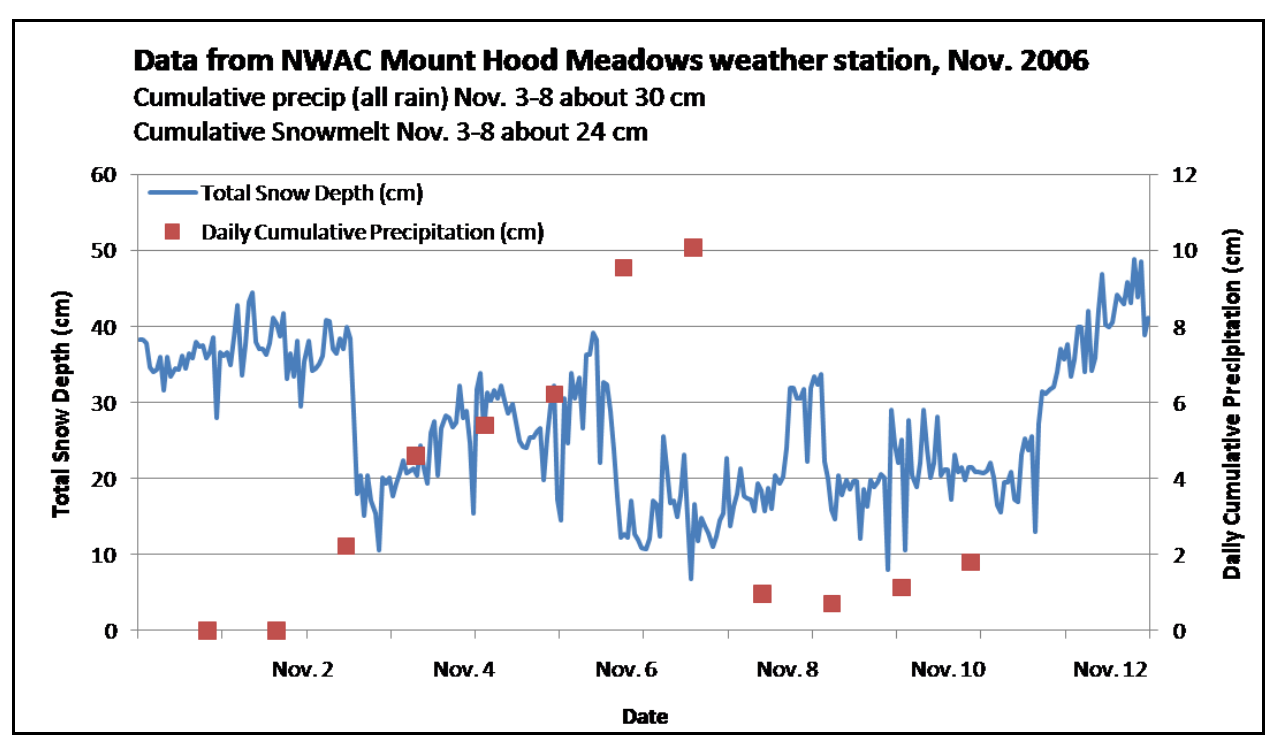

Figure 58. Mount Hood Meadows ski area data 


\section{CHAPTER 5: STATISTICS}

\section{DETERMINATION OF FACTORS}

Out of the factors and variables discussed in the Methods section, those that were equally comparable across both debris flow producing and non-debris flow basins were chosen for the statistical evaluation. Characteristics including "distance from the glacier" and "initiation zone elevation" were not taken into consideration as they could not be applied to those drainages which did not experience debris flows. The total basin catchment area and upper drainage basin area were not used to avoid redundancy because area was already part of Melton's Ruggedness Number. Basin height is also a parameter used in Melton's Ruggedness Number and was not included separately. The azimuth of a drainage basin is a geographic feature which affects rainfall and vegetation coverage. It was not used in the analysis because direct rainfall and vegetation numbers were already incorporated.

When reviewing the samples collected from drainages around the mountain, in general, pyroclastic derived sediment samples tended to have a higher proportion of sand to gravel and a lower percentage of fines than those samples that came from morainal material. When the samples were divided into two groups, those from drainages that did have debris flows as compared to those that did not have debris flows, the variation, or range of percentages of gravel, sand and fines, between the samples within each group was greater than the variation between the two groups. 
Therefore, the samples from drainages that did have debris flows were found to have no statistical difference from those that did not have debris flows. Because of this lack of distinction between groups, the results of the particle size analysis were not used in the statistical analysis of factors. The type of sediment in the upper drainage basin or initiation area was determined to be not a significant factor in discriminating between those drainages that had debris flows and those that did not and was not used in the statistical analysis.

\section{LOGISTIC REGRESSION}

Logistic regression is a form of generalized linear modeling that allows one to predict a discrete outcome from a set of variables. The purpose of this method is to predict the category of outcome for individual cases relying on as simple a model as possible. To accomplish this, a model is created which includes all predictor variables that may be useful in predicting the response variable (Agresti, 1996; SFSU, 2002.) The fit of the model will be tested after each coefficient is added or deleted using backward stepwise regression, where the analysis begins with a full model and variables are eliminated from the model systematically. A goodness of fit test is conducted after the elimination of each variable until no more variables can be eliminated with detriment to the fit of the model (Davis, 2002; SFSU, 2002). This method has been applied to geomorphologic problems which include linking of rockfall type to occurrence of lithologic variation within units (Vandewater et al., 
2005) and the prediction of the occurrence of debris flow production from an individual basin as a function of burned extent, soil properties, basin gradients and storm rainfall (Cannon et al., 2003).

\section{Method:}

The binary logistic regression analysis can predict group membership between two groups, or provide a response measurement for whether each subject is a "success" or "failure" (Agresti, 1996). An example of the prediction of group membership can be found with our test data set. In this instance the predicted $Y$ variable is debris flow occurrence defined by the actual documented occurrence of debris flows on Mount Hood from the November, 2006 storm. Those basins which experienced debris flows, regardless of size, were given a $Y$ designation of 1 in the data set. Those basins which did not experience debris flows were given a $\mathrm{Y}$ designation of 0 in the data set. Examples of the data can be found in appendix $M$.

Table 16 - Variables Measured for all Basins

\begin{tabular}{|l|l|}
$\mathbf{Y}=$ & Debris flow occurrence \\
$\mathbf{X} \mathbf{1}=$ & Rainfall amount \\
$\mathbf{X} \mathbf{2}=$ & Percent bedrock in the upper basin \\
$\mathbf{X} \mathbf{3}=$ & Percent vegetation in the upper basin \\
$\mathbf{X} 4=$ & Percent slopes above 33 degrees in the upper basin \\
$\mathbf{X 5}=$ & Gradient of the upper basin \\
$\mathbf{X 6}=$ & Connection to the glacier \\
$\mathbf{X 7}=$ & Glacier Area \\
$\mathbf{X 8}=$ & Melton's Ruggedness Number \\
\hline
\end{tabular}


To ensure better accuracy of the model, the first step necessary is to convert all observations to deviations from the mean. This reduces the absolute magnitude of variables and centers them around a common mean of zero (Davis, 2002). For our example, this step was conducted by converting the data to standard normal form using the equation $z_{i}=x_{i}-X / s$ from Davis, 2002. The results of the standardized data are presented in Appendix N. The variables used in this example are shown in Table 16.

The next step is to determine the influence of the eight independent $X$ variables on variable $\mathrm{Y}$. This is done through multiple regression. From the regression, the influence that all the variables have on debris flow occurrence can be assessed (Davis, 2002). This analysis was run on the data using least squares in order to obtain the coefficients of the predictor variables (Davis, 2002). Table 17 shows the results of the regression on the data set as a whole.

A Wald Test for goodness of fit is used to test the statistical significance of each coefficient in the model. A Wald test calculates a Z statistic which is then squared yielding a chi-square distribution (Agresti, 1996; SFSU, 2008) as shown below:

$$
\text { Wald }=z^{2}=\left(\mathbb{[} \frac{\beta}{S E_{\beta}}\right) \mathbf{]}^{2}
$$


where $\beta$ is the regression coefficient and $\mathrm{SE}_{\beta}$ is the standard error of the regression coefficient. The Wald Test has one degree of freedom (Hosmer and Lemshow, 1989). After running the first analysis, backward elimination is used to eliminate insignificant variables in order to produce the most economical model. The elimination of variables continues until the Wald test indicates that all regression coefficients are significant to the model, thereby weeding out insignificant variables.

Table 17 - Outputs and ANOVA for Regression 0

\begin{tabular}{|c|c|c|c|c|}
\hline \multicolumn{5}{|l|}{ ANOVA } \\
\hline & $d f$ & SS & $M S$ & $F$ \\
\hline Regression & 8.000 & 8.959 & 1.120 & 2.152 \\
\hline Residual & 2.000 & 1.041 & 0.520 & \\
\hline \multirow[t]{2}{*}{ Total } & 10.000 & 10.000 & & \\
\hline & Coefficients & Standard Error & $t$ Stat & $P$-value \\
\hline Intercept & 0.000 & 0.218 & 0.000 & 1.000 \\
\hline $\mathrm{X} 1$ & 0.460 & 0.401 & 1.146 & 0.370 \\
\hline $\mathrm{X} 2$ & -0.445 & 0.439 & -1.013 & 0.418 \\
\hline $\mathrm{x} 3$ & -0.385 & 0.553 & -0.697 & 0.558 \\
\hline$X 4$ & -0.033 & 0.368 & -0.089 & 0.937 \\
\hline $\mathrm{X} 5$ & -0.594 & 0.343 & -1.730 & 0.226 \\
\hline$x 6$ & 0.459 & 0.576 & 0.797 & 0.509 \\
\hline $\mathrm{X} 7$ & -0.040 & 0.415 & -0.095 & 0.933 \\
\hline $\mathrm{X} 8$ & 0.148 & 0.394 & 0.375 & 0.744 \\
\hline
\end{tabular}

The backward elimination procedure consists of computing a regression including all possible variables and selecting the least significant variable (Davis, 2002). The least significant variable was discarded, and the regression was recomputed, omitting that variable. The reduced regression model is then fitted to the data, and the process is repeated. At each step the regression equation is reduced by one variable, until all remaining variables are significant (Davis, 2002). With each reduction of the 
regression model, a new set of standardized partial regression coefficients is calculated.

The coefficients of the predictor variables or regression coefficients are then entered into the logistic regression equation. The equation for logistic regression (Eq 3) is shown below where $\alpha=$ the constant of the equation and $\beta=$ the coefficient of the predictor variables.

$$
\theta=\frac{e^{\left(\alpha+\beta_{1 X_{1}}+\beta_{2 X_{2}}+\cdots+\beta_{i X_{i}}\right)}}{1+e^{\left(\alpha+\beta_{1 X_{1}}+\beta_{2 X_{2}}+\cdots+\beta_{i X_{i}}\right)}}
$$

For this model, it was determined that the removal of five variables, $\mathrm{X} 1, \mathrm{X} 2, \mathrm{X} 4$, $\mathrm{X} 7$ and $\mathrm{X} 8$ resulted in the best fit model as predicted by the Wald test. Wald test results for the first five regressions are shown in Table 18. For the logistic regression model, the null hypothesis $\mathrm{H}_{0}: \beta=0$ states that the probability of success is independent of $X$ (Agresti, 1986). Rejection of the null hypothesis $H_{0}: \beta=0$ indicates coefficient is significant in the model. Wald numbers greater than 2.71 resulted in rejection of the null hypothesis at $\alpha=.10$.

The regression outputs for Regression 5 are shown in Table 19. Of the three significant variables, X3 (\% Vegetation) and X5 (Gradient) show an inverse relationship to debris flow occurrence, while X6 (Connection to the glacier) shows a normal relationship. The test statistic therefore is: 


$$
\theta=\frac{e^{0+\left(-.562 * X_{1}\right)+\left(-.568 * X_{2}\right)+\left(346 * X_{2}\right)}}{1+e^{0+\left(-.562 * X_{1}\right)+\left(-.568 * X_{2}\right)+\left(346 * X_{3}\right)}}
$$

Table 18 - Results from first five regressions showing Wald results for coefficients

\begin{tabular}{|c|c|c|c|c|c|}
\hline \multicolumn{2}{|c|}{ Regression 0} & \multicolumn{2}{|c|}{ Regression 1} & \multicolumn{2}{|c|}{ Regression 2} \\
\hline Coefficient & WALD & Coefficient & WALD & Coefficient & WALD \\
\hline$\beta_{1}$ & 1.31 & $\beta_{1}$ & 1.95 & $\beta_{1}$ & 2.57 \\
\hline $\boldsymbol{\beta}_{2}$ & 1.03 & $\boldsymbol{\beta}_{2}$ & 1.70 & $\boldsymbol{\beta}_{2}$ & 2.29 \\
\hline$\beta_{3}$ & 0.49 & $\boldsymbol{\beta}_{3}$ & 1.23 & $\boldsymbol{\beta}_{3}$ & 1.86 \\
\hline $\boldsymbol{\beta}_{4}$ & 0.01 & $\boldsymbol{\beta}_{5}$ & 5.03 & $\beta_{5}$ & 6.72 \\
\hline$\beta_{5}$ & 2.99 & $\beta_{6}$ & 1.87 & $\beta_{6}$ & 3.11 \\
\hline$\beta_{6}$ & 0.64 & $\beta_{7}$ & 0.01 & $\boldsymbol{\beta}_{8}$ & 0.28 \\
\hline$\beta_{7}$ & 0.01 & $\beta_{8}$ & 0.20 & & \\
\hline$\beta_{8}$ & 0.14 & & & & \\
\hline \multicolumn{2}{|c|}{ Regression 3} & \multicolumn{2}{|c|}{ Regression 4} & \multicolumn{2}{|c|}{ Regression 5} \\
\hline Coefficient & WALD & Coefficient & WALD & Coefficient & WALD \\
\hline$\beta_{1}$ & 2.87 & $\beta_{1}$ & 1.00 & $\beta_{3}$ & 7.46 \\
\hline$\beta_{2}$ & 2.34 & $\beta_{3}$ & 8.30 & $\beta_{5}$ & 11.08 \\
\hline$\beta_{3}$ & 2.35 & $\beta_{5}$ & 10.58 & $\beta_{6}$ & 2.96 \\
\hline$\beta_{5}$ & 7.84 & $\beta_{6}$ & 1.85 & & \\
\hline$\beta_{6}$ & 4.51 & & & & \\
\hline
\end{tabular}

Table 19 - Output and ANOVA for Regression 5

\begin{tabular}{|c|c|c|c|c|}
\hline \multicolumn{5}{|l|}{ ANOVA } \\
\hline & $d f$ & SS & $M S$ & $F$ \\
\hline Regression & 3.000 & 8.073 & 2.691 & 9.777 \\
\hline Residual & 7.000 & 1.927 & 0.275 & \\
\hline \multirow[t]{2}{*}{ Total } & 10.000 & 10.000 & & \\
\hline & Coefficients & $\begin{array}{l}\text { Standard } \\
\text { Error }\end{array}$ & tStat & $P$-value \\
\hline $\begin{array}{l}\text { Intercept } \\
\text { X3 }\end{array}$ & 0.000 & 0.158 & 0.000 & 1.000 \\
\hline $\begin{array}{l}\text { (Vegetation) } \\
\text { X5 }\end{array}$ & -0.562 & 0.206 & -2.732 & 0.029 \\
\hline $\begin{array}{l}\text { (Gradient) } \\
\mathrm{X} 6 \\
\text { (Connection }\end{array}$ & -0.568 & 0.171 & -3.329 & 0.013 \\
\hline to Glacier) & 0.346 & 0.201 & 1.721 & 0.129 \\
\hline
\end{tabular}


The output for the logistic regression model is in the form of an odds ratio yielding a percentage as the final result. Large percentage numbers indicate a higher probability of a basin with those particular characteristics being classified as having a debris flow. Table 20 shows results for the logistic regression. Name indicates basin name; $\mathrm{Y}$ is the observed result with 1 representing having had a debris flow and 0 representing not having had a debris flow; and Regression 5 gives the percent probability that a basin with that basin's characteristics would have a debris flow. For the purposes of this study, while $Y=1$ for those actually having a debris flow, a percentage above $50 \%$ was taken to indicate a positive correlation with real world values and a percentage lower than $50 \%$ indicated a negative result. In all but one case, the prediction of the model followed the physical documentation of presence or absence of a debris flow in a given basin. For the one case where the model did not predict a debris flow, the phi value for that basin was $48 \%$, very close to $50 \%$. This yielded an accuracy of $90 \%$ for the model based on the Mount Hood drainage basins, or $90 \%$ of the basins having $>50 \%$ chance of debris flows actually had them. Of the eight basin scale factors tested for statistical relevance in the production of debris flows, surface water connection to the glacier, amount of vegetation in the upper basin, and gradient of the upper basin were the most important factors for the November, 2006 debris flow events. The phi value is telling you the probability of a basin with those characteristics having a debris flow. 
Table 20 - Sample of results from logistic regression

\begin{tabular}{|llc|}
\hline Name & Y & Regression \\
\hline White & 1 & $76 \%$ \\
Newton & 1 & $69 \%$ \\
Ladd & 1 & $66 \%$ \\
Clark & 1 & $65 \%$ \\
Eliot & 1 & $62 \%$ \\
Salmon & 1 & $62 \%$ \\
\hline Sandy & 1 & $48 \%$ \\
Coe & 0 & $41 \%$ \\
Zigzag & 0 & $28 \%$ \\
Muddy & 0 & $24 \%$ \\
Polallie & 0 & $17 \%$ \\
\hline
\end{tabular}

\section{Limitations, Input Requirements, \& Assumptions:}

The variables used in logistic regression can be discrete, continuous, dichotomous, or a combination of any of these. The dependent variable or the response is usually dichotomous indicating a presence/absence, or group membership within one of two groups. The independent variables can take any form as logistic regression makes no assumption about the distribution of the independent variables. It is not necessary for them to be normally distributed, of equal variance, or linearly related (Davis, 2002; SFSU, 2008).

Problems with goodness of fit for the linear regression model can occur at many stages. In linear regression the method used most often for estimating unknown parameters is least squares; however, this is not the best fit for a model with a dichotomous outcome. The maximum likelihood function can provide a much better 
estimation of unknown parameters in small data sets (Hosmer and Lemshow, 1989). For the purposes of this model, least squares were used due to software limitations. The Wald test can also be a source of error. The performance of the Wald test is sometimes found to be inconsistent, often failing to reject when the coefficient was significant. Use of the likelihood ratio has been recommended by Hosmer and Lemshow, 1989. The Wald test was chosen over the likelihood ratio for our example due to software limitations. It is also important to standardize the data in order to avoid skewing the results. However, if the data are standardized and the logistic regression model is intended to be used with raw data, it is necessary to "unstandardize" the partial regression coefficients beforehand (Davis, 2002). Our example used the original normalized data to check the test, and therefore this additional step was unnecessary.

Other sources of error can be found in the input data. Rainfall data used from the NEXRAD storm total data has been shown to report 33 to 38 percent lower than NWAC data in the upper elevations. However, NEXRAD was used because it is the only source of rainfall data that offers complete coverage for the mountain. The resolution of the LiDAR data for Mount Hood, used as a basis for calculating other factors, is a 1 meter resolution and may also be a source of error. Additionally, the limits of some factors such as upper drainage basin area were dependent upon a 
manual selection process that may be applied differently if someone else were to evaluate the basins.

\section{Summary:}

Binary logistic regression is an adaptable method that can be used when dealing with variables that are seemingly unrelated. It allows the prediction of a discrete outcome such as group membership. Backward stepwise regression is the preferred method of exploratory analyses where the process begins with a full model and variables are eliminated in an iterative process. The fit of the model should be tested after the removal of each variable. When fit tests show that all remaining variables are significant, no more variables should be eliminated from the model (SFSU, 2008). The process by which coefficients are tested for significance can involve several different techniques. The Wald test was used in our model; however the likelihood ratio test may be more reliable. The output of the logistic regression model is a percentage representing the estimated probability that $Y=1$ at a fixed setting (Agresti, 1996). The three most important factors for debris flow production for this storm event were connection to the glacier, vegetation in the upper basin, and gradient of the upper basin. Percent vegetation in the upper basin and gradient both show an inverse relationship to debris flow occurrence. Those basins with less vegetation and lower gradients appear more likely to experience debris flows than steep gradient basins with more vegetation. 
When running the logistic regression analysis in addition to the end result of the analysis, the order in which the factors dropped out was also important. While all of the factors may be important, the final result factors were the most statistically significant for this mountain and this storm event. The least significant factor, the one that dropped out first, was the percent steep slopes in the basin. The next to drop out was glacier area followed by Melton's Ruggedness Number. Percent bedrock in the upper basin was removed after running regression three. Rainfall amount was the last factor to be removed, indicating that it is closely related to the three remaining factors that did pass the test for significance. In addition to important factors, loading of debris channels may also play a significant role in debris flow production. 


\section{CHAPTER 6: DISCUSSION}

The Pineapple Express storm that occurred in November, 2006 was a large storm for the region. At the time that the storm occurred, the mountain did not yet have any significant snow cover. Snow on the mountain can act as a blanket and absorb precipitation. While snow cover can contribute to faster, more peaked runoff hydrographs for overall stream flow, it can also form a thick blanket in the upper elevations to absorb precipitation and inhibit debris flow production when initiation zones are sufficiently snow covered. This storm provided a trigger for the transportation of material on the mountain, in the form of debris flows, in part because of the high rainfall at upper elevations, and in part because there was no snow cover to absorb the precipitation at the initiation zones.

Debris flows initiated on all sides of Mount Hood. Rainfall amounts were highest on the west side of Mount Hood with over $35 \mathrm{~cm}$ of precipitation recorded by NEXRAD. Rainfall on the east side measured minimums between $15 \mathrm{~cm}$ and $21 \mathrm{~cm}$. A minimum of $15 \mathrm{~cm}$ of rainfall in 6 days was the apparent lower threshold for debris flow production because no debris flows were observed in areas that received less rainfall than this. However, abundant rainfall does not guarantee debris flow production as a minimum of over $35 \mathrm{~cm}$ of rain in 6 days was not enough to generate debris flows in the Zigzag or Muddy Fork basins. NWAC data also suggest that rapid snowmelt of a thin snow cover in at least some of the initiation areas may have 
played an important role in contributing to high streamflow rates in the upper elevations.

Very little antecedent moisture was recorded at the SNOTEL sites in the ten days prior to the storm. However, permeable soils, a prolonged storm and evidence for numerous shallow slides in mountain canyons indicate that saturation of the soil is highly probable. It is possible that a buildup of pore pressure on residual ice within the deposits may have played a role, however more likely is that undercutting of the banks or some combination of the two was the trigger for the landslides. Visual evidence noted in the field supports the idea that undercutting of the banks in the areas where landslides occurred was a primary trigger for slides. Wet patches of residual ice were also noted in all landslide scars in the field.

An analysis of particle size for initiation zone material, less than cobble sized, showed no statistical difference between debris flow and non debris flow producing basins. In general there were few fines (3-5\%). Deposits were mostly sandy, especially in the pyroclastic materials as compared to moraines. Gravel ranged from $15-49 \%$, sand ranged $45-82 \%$ with coarse sand as the main sand fraction. The average bulk density of deposits was $1.6-1.8 \mathrm{~g} / \mathrm{cm}^{3}$.

After evaluating all the major basins on Mount Hood with Melton's Ruggedness Number, it appears that all drainages investigated in this study are capable of 
producing debris flows because all of the calculated ruggedness numbers were greater than 0.3. Historic records for the mountain support this finding, because all of the eleven primary drainages are on record as having experienced debris flows in the past with the exception of the Zigzag River (DeRoo, 2009).

In order to determine the most important factors for debris flow production for the November 2006 storm, logistic regression was applied to several basin scale factors. Of the eight basin scale factors tested, connection to the glacier, amount of vegetation in the upper basin, and gradient of the upper basin were the most important factors for the November, 2006 debris flow events.

The relationship of inverse gradient as a significant factor is a somewhat surprising one. Almost all of the drainages that did not experience debris flows had steeper gradients than those that did. At first glance this may seem somewhat counter intuitive. However, steeper gradients mean faster erosion rates. If sediments are actively being eroded in a basin, than it makes it more difficult to have a buildup of sediment that could morph into a debris flow in the upper drainage basin. This, combined with heavy vegetation in the upper basin helps explain why these drainages did not experience debris flows. There was a lack of buildup of sediment in the upper basins due to both increased erosion rates from the steep gradients and lack of susceptible areas to slope failure due to higher vegetation percentages. 
The final factor that plays a significant role in why some drainages experienced debris flows and others didn't is the direct, overland connection to the glacier. Those drainages that have a direct connection to the glacier receive additional runoff and melt-water from the glacier during storm events compared to similar drainages that are fed through groundwater infiltration. A connection to the glacier provides a direct pathway for immediate increased stream flow as compared to those drainages that are not connected to the glacier. The glacier acts, more or less, as an area of impermeable surface, feeding additional runoff to the streams. This increased stream flow means that the streams have more energy to create more work in the form of erosion to canyon sidewalls. Those sidewalls that are unvegetated are especially vulnerable to erosion.

Because of the granular nature of the sediments in the initiation areas and the lack of fines to create cohesion within the soil, it is likely that increased stream flow caused undercutting of the banks in vulnerable areas and that led to the landslide activity. This idea is supported by evidence from the field which shows streams meandering up against and into those landslide areas. Therefore, it can be concluded that high runoff in streams is critical to the initiation of debris flows in upper basin areas.

Another important conclusion was the role that glaciers and residual snowpack play in contributing runoff to streams. Entrainment of debris through overland flow 
into coalescing rills which morphed into debris flows, and undercutting of the banks of streams causing mobilization landslides which morphed into debris flows were the two primary debris flow triggering mechanisms. Both of these mechanisms rely on surface water flow, whether channelized or unchannelized. Therefore, the additional surface water provided by rapid snowmelt may significantly contribute to the initiation of debris flows.

The elevation of the initiation zone is also dependent on the connection a drainage has with a glacier because the source material for many of the debris flows was glacial moraines. Additionally, landslide initiated debris flows commonly occurred where the two lateral moraines narrowed and the river cut through. Many of the elevations for the initiation zones of debris flows in the November 2006 storm occurred in a narrow elevation band because this elevation is representative of the distal extent of the most recent glacial moraine deposits on the mountain.

Finally, basin transport and weathering mechanisms were also important. Most of the drainage basins on Mount Hood could be described as transport limited. They have an abundance of unconsolidated sediment in the upper drainage basin in the form of either morainal or pyroclastic material. These sediments provide a near constant input to the stream channel. The drainage needs only the right amount of precipitation to trigger the transportation of these sediments (Jakob et al., 2005). Therefore, they are transport limited. The Muddy Fork of the Sandy River is one 
exception. The Muddy Fork contains a large amount of bedrock in the upper basin rather than unconsolidated sediments. The 2002 Muddy Fork debris avalanche showed that the mechanism for initiation debris flows is distinctly different for this basin. The mechanism for debris flow triggering in the Muddy Fork involves weathering of rock in the upper basin until an event of significant magnitude, such as a large-scale rock avalanche, triggers a subsequent debris flow. Therefore, this basin can be described as weathering limited. This difference in channel recharge mechanism may provide another explanation why the Muddy Fork did not experience a debris flow as a result of the November 2006 storms. It simply had not reached a weathering threshold that would allow it to trigger a debris flow. While high discharge flows would have been expected in a basin with ice and bedrock surfaces due to flash responses, there was not a sufficient amount of loose debris along the channel margins to entrain into a debris flow. Additionally, the steep gradients seen on bedrock dominate upper drainage basins helps ensure the efficient evacuation of debris through normal stream flow processes. This means that there is a lower likelihood of debris flow occurrence because there is simply less sediment in the system. All of these conclusions apply to the drainages on Mount Hood in different ways.

The Zigzag River and the Polallie Creek did not experience debris flows in this event because they do not have a direct connection to the glacier, and they contain 
abundant vegetation in the upper basin. Additionally, the Zigzag River has a steeper gradient which may more easily facilitate the transport of debris downstream. The Coe Creek did not experience debris flows because it also had an abundance of vegetation in the upper basin. The Muddy Fork of the Sandy River did not experience a debris flow because it has a high percentage of vegetation in the upper basin and a very steep gradient. This steep gradient may more easily facilitate the transport of debris downstream resulting in a drainage that has a lower amount of available material for transport. The Muddy Fork of the Sandy River is a weathering limited basin where mobilization of debris flows depends heavily on erosion rates. Because of the granular nature of the sediments in the initiation areas and the lack of fines to create cohesion within the soil, it is likely that increased stream flow caused undercutting of the banks in vulnerable areas and that led to the landslide activity. This idea is supported by evidence from the field which shows streams meandering up against and into those landslide areas. Therefore, it can be concluded that high runoff rates in streams are key to the initiation of debris flows.

For the November 2006 debris flow event, the Eliot Creek Basin and the White River Basin posed the greatest threat to infrastructure and lives. The $16 \mathrm{~km}$ Eliot Creek debris flow and $8 \mathrm{~km}$ White River debris flow caused significant damage to infrastructure. The $12 \mathrm{~km}$ Newton Creek and $8 \mathrm{~km}$ Sandy River both posed a lower threat to lives and infrastructure than the Eliot Creek and White River. While the 
debris flow in the Sandy River Basin was medium large, the source area was far enough away from infrastructure to dampen its direct impacts. The large Newton Creek debris flow more directly impacted infrastructure, but the infrastructure was further away from the source area than in the case of the White River. The Ladd Creek, Clark Creek, and East Fork of the Salmon River produced the smallest debris flows on the mountain, ranging from $3 \mathrm{~km}$ to $4 \mathrm{~km}$, and resulted in the least amount of damages to infrastructure. However, it should be stressed that even when debris flows do not impact roads or bridges, Mount Hood is a popular recreation destination and deaths can be caused due to the dangers of attempting river crossings after a debris flow has gone through. 


\section{CHAPTER 7: CONCLUSIONS}

- 7 of the 11 drainages produced debris flows as a result of the November, 2006 storm. 4 were landslide initiated and 3 were headless debris flows.

- The Eliot Creek and White River resulted in highest amount of damages to infrastructure. Newton Creek and the Sandy River also produced large debris flows on the mountain. All of these flows ranged from $8 \mathrm{~km}$ to 16 $\mathrm{km}$.

- The Ladd Creek, Clark Creek, and East Fork of the Salmon River produced the smallest debris flows on the mountain, ranging from $3 \mathrm{~km}$ to $4 \mathrm{~km}$, and resulted in the least amount of damages to infrastructure.

- Particle size analysis of the material in the upper drainage basins showed no statistical difference between those drainages that produced debris flows and those that did not. Average percentage ranges are given below:
○ Gravel $\quad 15 \%-49 \%$
○ Sand $\quad 45 \%-82 \%$
- Fines $\quad 1.6 \%-5 \%$

- Precipitation amounts were highest on the west side of the mountain with a minimum of $36 \mathrm{~cm}$ reported for debris flow producing basins by NEXRAD. Precipitation amounts were lowest on the east side of the mountain with a minimum of $15 \mathrm{~cm}$ reported for debris flow producing basins. 
- In the November 2006 storm event, debris flow production did not occur below a threshold of $15 \mathrm{~cm}$ of total storm rainfall.

- An analysis of all drainages using Melton's Ruggedness number indicated that all drainage basins on Mount Hood are capable of producing debris flows as they all had a Melton Number greater than 0.3.

- Regression analysis using factors that affect the rate of rainfall runoff in a basin predicted debris flows for $90 \%$ of the basins that actually had debris flows.

- The three most important factors, determined by logistic regression, were surface water connection to the glacier, percent vegetation in the upper basin, and gradient of the upper basin.

- Percent vegetation and gradient both had an inverse relationship to debris flow occurrence.

- Surface water connection to the glacier provides additional discharge to the stream. The glacier acts as an impermeable surface to direct additional rainwater to the stream, and provides rapid snowmelt which leads to increased input of water to the stream during storm events.

- The consistency of the initiation zone elevation is connected to the relationship that a drainage has with a glacier because the exposure of moraines in many cases provided the source area material for the debris flows. 
- The average initiation elevation for debris flow production was $1,860 \mathrm{~m}$.

- Initiation elevations were slightly higher on the west side of the mountain because the vegetation reaches to higher elevations on the west than on the east. This is due to generally higher rainfall on the west side of the mountain.

- Drainages with less vegetation have more marginally stable slope areas that are especially vulnerable to the entrainment and undercutting processes that aided in the initiation of debris flows.

- A moderate gradient basin is more susceptible to debris flows than those with very steep gradients. Those basins with steeper gradients are more able to facilitate the transport of debris through normal stream flow processes. This lessens the potential build-up of material for transport in debris flows.

- The Muddy Fork drainage basin is not transport limited.

- Weathering mechanisms within a basin control the ability of that basin to produce debris flows. Transport limited basins, filled with unconsolidated sediment deposits, are always able to produce debris flows given the right climatic trigger. Bedrock dominated weathering limited basins take a longer time to build up material for transport and will not necessarily produce debris flows, even with a very strong climatic trigger. 


\section{CHAPTER 8: FUTURE WORK}

The use of the results of logistic regression from this study could be applied to other volcanoes in the Pacific Northwest to assist in debris flow hazard awareness. Additionally, the methods for obtaining the basin scale factors could be refined and further automated through Arc GIS. The size of the upper drainage basin could be adjusted to provide a more detailed analysis of the initiation zone, or be further expanded to match the basin area used for the calculation of Melton's Ruggedness Number. The logistic regression factors defined here can be used to compliment Melton's Ruggedness Number for identification of debris flow hazard areas.

Additionally, maps highlighting high debris flow hazard drainages could be produced for other volcanoes using these conclusions.

The results of the statistical analysis indicate that factors which control debris flows have a direct relationship to streamflow and sediment transportation within a basin. Future studies could be conducted to better quantify the sediment transport of high gradient basins versus those with modest gradients as it appears that those basins with modest gradients are more likely to produce debris flows. Additionally, future work could be focused on quantifying the relationship between increased streamflow in the channel and undercutting of the banks as it appears that this process controls landslide occurrence in the channel which then morphs into debris flows. 


\section{WORKS CITED}

Agresti, A. (1996). An Introduction to Categorical Data Analysis. New York: John Wiley and Sons, Inc.

Agresti, A. (1986). Statistical Methods for the Social Sciences. San Francisco: Dellen Publishing Company.

Anderson, D. A., DeRoo, T. G., \& D, H. C. (2006). Response to 1998 debris flow in the upper White River Valley, Oregon. Oregon Geology, v.67, no. 1, p. 7-10 .

Bovis, M. J., \& Jakob, M. (1999). The role of debris supply conditions in predicting debris flow activity. Earth Surface Processes and Landforms, v. 24 , p. 1039-1054.

Burns, S. F., Pirot, R. P., Sobieszcyk, T., \& Williams, K. (2009). Massive debris flow Events on Pacific Northwest volcanoes, November, 2006; as the climate changes, more debris flow events to come. Geological Society of America annual meeting, abstracts with programs, vol. 41, number 7, p. 716. Portland.

Cameron, K. A., \& Pringle, P. T. (1987). A detailed chronology of the most recent major eruptive period at Mount Hood, Oregon. Geological Society America Bulletin, v. 99 , p. 845851.

Cameron, K. A., \& Pringle, P. T. (1986). Post-glacial lahars of the Sandy River Basin, Mount Hood, Oregon. Northwest Science, v.60, no.4, p. 225-237.

Cannon, S. H., Gartner, J. E., Rupert, M. G., \& Michael, J. A. (2003). Emergency assessment of debris-flow hazards from basins burned by the Grand Prix and Old Fires of 
2003, Southern California. U.S. Department of the Interior, U.S. Geological Survey, Open-File Report of-03-475, $10 \mathrm{p}$.

Carson, M. A., \& Kirkby, M. J. (1972). Hillslope Form and Process. Cambridge: Cambridge University Press.

Church, M., \& Miles, M. J. (1987). Meteorological antecedents to debris flow in southwestern British Columbia; some case studies. In J. E. Costa, \& G. F. Wieczorek (Eds.), Debris Flows/Avalanches: Process, Recognition and Mitigation. Reviews in Engineering Geology, v. VII. Geological Society of America p. 63-79.

Clark, S. K., \& Burns, S. (2005). Muddy Fork Debris Avalanche and Debris Flow, Mount Hood, Oregon: Failure Attributes, Characterization, and Significance. First Annual ColumbiaWillamette Sigma Xi Student Research Symposium. April 21, 2005, Portland State University.

Coe, J. A., Godt, J. W., Parise, M., \& Moscariello, A. (2003). Estimating debris-flow probability using fan stratigraphy, historic records, and drainage-basin morphology, Interstate 70 highway corridor, central Colorado, U.S.A. In D. Rickenmann, \& C. Chen (Eds.), Debris-Flow Hazards Mitigation: Mechanics, Prediction and Assessment. Rotterdam: Millpress p. 1085-1096.

Copeland, E. A., Kennard, P., Nolin, A. W., Lancaster, S. T., \& Grant, G. E. (2008). Initiation of Recent Debris Flows on Mount Rainier, Washington: A Climate Warming Signal? American Geophysical Union, Fall Meeting 2008, abstract \#H51F-0887. San Francisco: American Geophysical Union. 
Crandell, D. (1980). Recent Eruptive History of Mount Hood, Oregon, and Potential Hazards from Future Eruptions. U.S. Geological Survey Bulletin 1492, U.S. Government Printing Office, Washington .

Davis, J. C. (2002). Statistics and Data Analysis in Geology Third Edition. New York: John Wiley \& Sons, Inc.

DeRoo, T. (2009). personal communication. U.S. Forest Service, Mt. Hood National Forest

Driedger, C. L., \& Kannard, P. M. (1986). Ice Volumes on Cascade Volcanoes: Mount Rainier, Mount Hood, and Mount Shasta. Geological Survey Professional Paper 1365. USGS.

Gallino, G. L., \& Pierson, T. C. (1985). Polallie Creek Debris Flow and Subsequent DamBreak Flood of 1980, East Fork Hood River Basin, Oregon. U.S. Geological Survey WaterSupply Paper 2273, 22 p.

Gardner, C. A., Scott, W. E., Major, J. J., \& Pierson, T. C. (2000). Mount Hood - History and Hazards of Oregon's Most Recently Active Volcano. U.S. Department of the Interior, U.S. Geological Survey, USGS Fact Sheet 060-00 .

Godt, J. W., \& Coe, J. A. (2007). Alpine debris flows triggered by a 28 July 1999 thunderstorm in the central Front Range, Colorado. Geomorphology, v. 84 , p. 80-97.

Hosmer, D. W., \& Lemshow, S. (1989). Applied Logistic Regression. New York: John Wiley \& Sons, Inc. 
Iverson, R. M. (2000). Landslide triggering by rain infiltration. Water Resources Research, v. 36 , p. $1897-1910$.

Iverson, R. M. (2003). The debris-flow rheology myth. In D. Rickenmann, \& C. Chen (Eds.), Debris Flow Hazards Mitigation: Mechanics, Prediction, and Assessment. Rotterdam: Millpress, 303-314.

Iverson, R. M. (1997). The physics of debris flows. Reviews of Geophysics , p. 245-296.

Iverson, R. M., Reid, M. E., \& LaHusen, R. G. (1997). Debris-flow mobilization from landslides. Annual Review of Earth and Planetary Sciences, v. 25 , p. 85-138.

Iverson, R. M., Schilling, S. P., \& W, V. J. (1998). Objective delineation of lahar-inundation hazard zones. Geological Society of America Bulletin, v. 110 , p. 972-984.

Jackson, K. M. (2007). The mass wastage and flow of Eliot Glacier, Mt. Hood, Oregon. MS. Thesis, Department of Geography, Portland State University, 109 pp.

Jackson, K. M., \& Fountain, A. G. (2007). Spatial and morphological change on Eliot Glacier, Mount Hood Oregon, USA. Annals of Glaciology, 46, p. 222-226.

Jackson, L. E., Kostachuk, R. A., \& MacDonald, G. M. (1987). Identification of debris flow hazard on alluvial fans in the Canadian Rocky Mountains. In J. E. Costa, \& G. F. Wieczorek (Eds.), Debris Flows/Avalanches: Process, Recognition and Mitigation. Reviews in Engineering Geology, v. VII. Geological Society of America, p. 115-124. 
Jakob, M., Bovis, M., \& Oden, M. (2005). The significance of channel recharge rates for estimating debris-flow magnitude and frequency. Earth Surface Processes and Landforms v. 30, p. $755-766$.

KATU news. (2006, November 6). KATU Storm Alert blog - November 6. Retrieved April 17, 2010, from KATU.com: http://www.katu.com/news/4579007.html

Marchi, L., \& Dalla Fontana, G. (2005). GIS morphometric indicators for the analysis of sediment dynamics in mountain basins. Environmental Geology v. 48 , p. 218-228.

Melton, M. A. (1965). The geomorphic and paleoclimatic significance of alluvial deposits in southern Arizona. Journal of Geology, v. 73 , p. 1-38.

NEXRAD. (2009, February 12). NCDC NEXRAD data inventory data search. Retrieved from NOAA Satalite and Information Services: national environmental satallite, data, and information services: http://www.ncdc.noaa.gov/nexradinv

Oregon Department of Transportation (ODOT). (2006, November). Region 1 News. Retrieved April 17, 2010, from Oregon.gov: http://www.oregon.gov/ODOT/HWY/REGION1/news/RebuildingOregon35.pdf

Osterkamp, W. R., \& Hupp, C. R. (1987). Dating and interpretation of debris flows by geologic and botanical methods at Whitney Creek Gorge, Mount Shasta, California. In J. E. Costa, \& G. F. Wieczorek (Eds.), Debris Flows/Avalanches: Process, Recognition and Mitigation. Reviews in Engineering Geology, v. VII. Geological Society of America, p. 157-163. 
Pierson, T. C. (2005). Distinguishing between debris flows and floods from field evidence in small watersheds. U.S. Geological Survey, USGS Fact Sheet 2004-3142 , 4 p.

Pierson, T. C. (2007). United States Geological Survey, Cascade Volcano Obsevertory. Vancouver: personnal communication.

Pierson, T. C., \& Costa, J. E. (1987). A rheologic classification of subaerial sediment-water flows. In J. W. Costa, J. E. Costa, \& G. F. Wieczorek (Eds.), Debris Flows/Avalanches: Process, Recognition and Mitigation. Reviews in Engineering Geology, v. VII. Geological Society of America, p. 1-12.

Rapp, E. K. (2005). The Holocene Stratigraphy of the Sandy River Delta, Oregon [M.S. thesis]. Portland State University, 99 p.

Ritter, D. F. (2002). Process Geomorphology. New York: Mc-Graw-Hill.

Scott, S. P.; Pierson, T. C.; Schilling, S. P.; Costa, J. E.; Gardner, C. A.; Vallance, J. W.; Major, J. J. (1997). Volcano Hazards in the Mount Hood Region, Oregon. U.S. Geological Survey Open File Report 97-89, 16 p.

SFSU. (2002). Logistic Regression. Retrieved November 17, 2008, from San Francisco State University: http://userwww.sfsu.edu/ efc/classes/biol710/logistic/logisticreg.htm

Sherrod, D. R., \& Scott, W. E. (1995). Preliminary Geologic Map of the Mount Hood 30- by 60- Minute Quadrangle, Northern Cascade Range, Oregon. U.S. Geological Survey Open File Report 95-219, 28 p. 
Sobieszczyk, S., Uhrich, M. A., Piatt, D. R., \& Bragg, H. M. (2009). Analysis of geomorphic and hydrologic characteristics of Mount Jefferson debris flow, Oregon, November 6, 2006. Geological Society of America Abstracts with Programs, Vol. 41, No. 7 (p. 499). Portland: Geological Society of America.

Swanson, D. A., Cameron, K. A., Evarts, R. C., Pringle, P. T., \& Vance, J. A. (1989). Cenozoic Volcanism in the Cascade Range and Columbia Plateau, Southern Washington and Northernmost Oregon. American Geophysical Union, AGU Field Trip Guidebook T106, July 38, 1989 .

Vandewater, C. J., Dunne, W. M., Mauldon, M., Drumm, E. C., \& Bateman, V. (2005). Classifying and assessing the geologic contribution to rockfall hazard. Environmental and Engineering Geoscience, vol.XI, no. 2, p. 141-154 .

Wells, W. G. (1987). The effects of fire on the generation of debris flows in southern California. In J. Costa, \& G. Wieczorek (Eds.), Debris Flows/Avalanches: Process, Recognition and Mitigation. Reviews in Engineering Geology, v. VII. Geological Society of America, p. 105114.

Wieczorek, G. (1987). Effect of rainfall intensity and duration on debris flows in central Santa Cruz Mountains, California. In J. Costa, \& G. Wieczorek (Eds.), Debris Flows/Avalanches: Process, Recognition and Mitigation. Reviews in Engineering Geology, v. VII. Geological Society of America, p. 93-104. 
Wilford, D. J., Sakals, M. E., Innes, J. L., Sidle, R. C., \& Bergerud, W. A. (2004). Recognition of debris flow, debris flood and flood hazard through watershed morphometrics. Landslides v. I, p. 61-66. 
APPENDIX A: $\quad$ ELIOT CREEK DRAINAGE BASIN

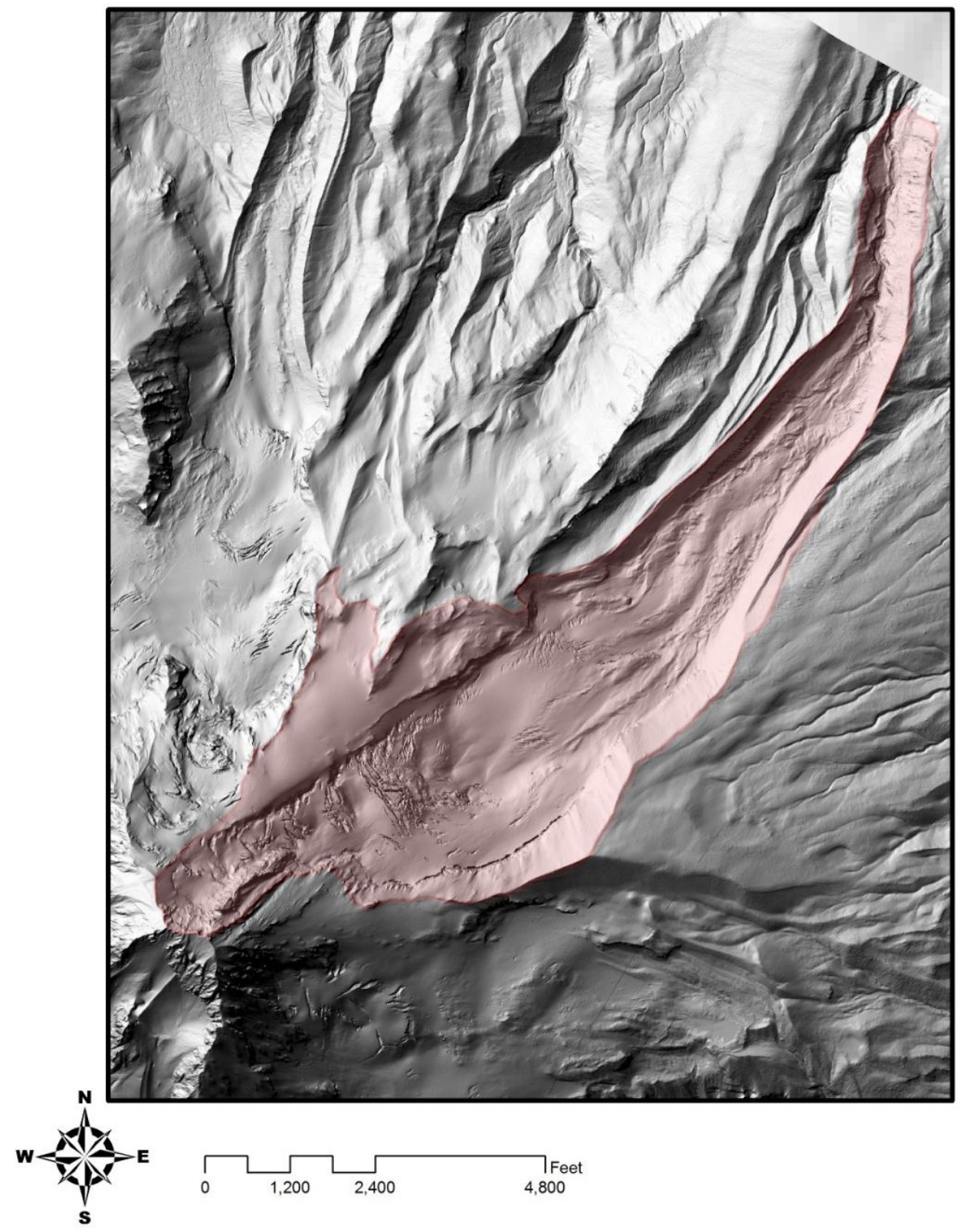

Figure 59. Eliot Creek upper drainage basin $\left(3,279,707 \mathrm{~m}^{2}\right)$ 


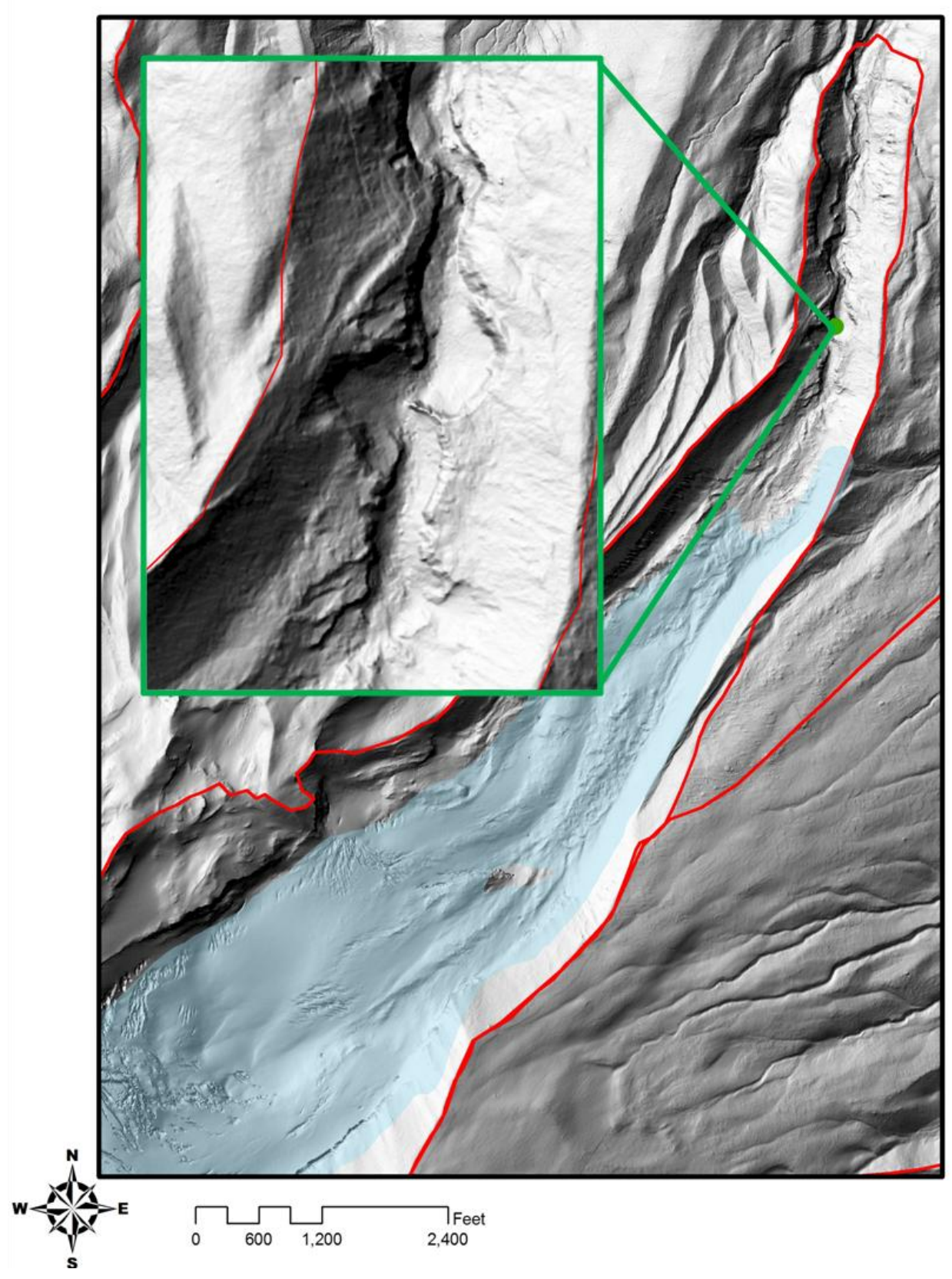

Figure 60. Eliot Creek initiation zone 


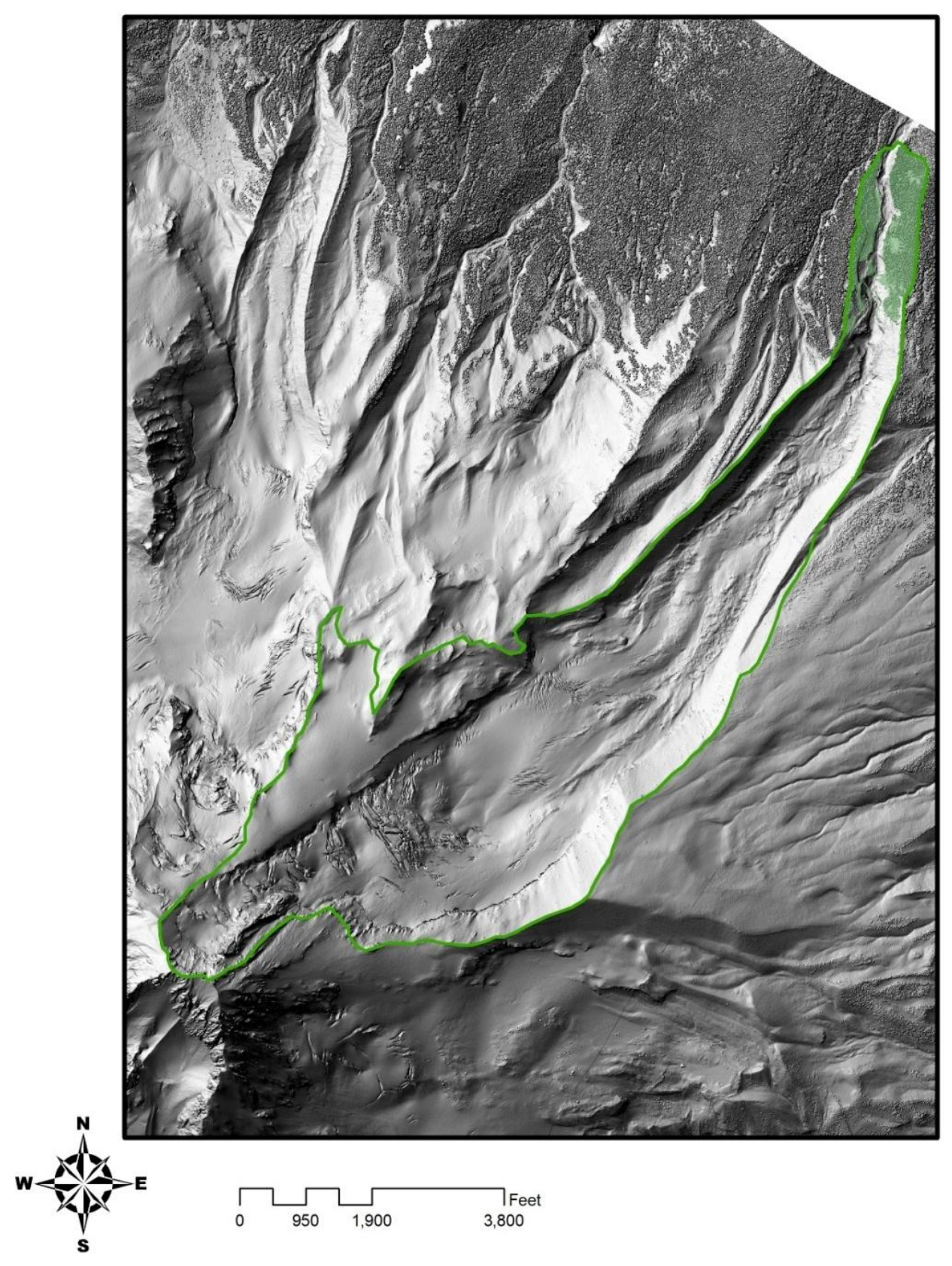

Figure 61. Eliot Basin vegetation (4.3\%) 


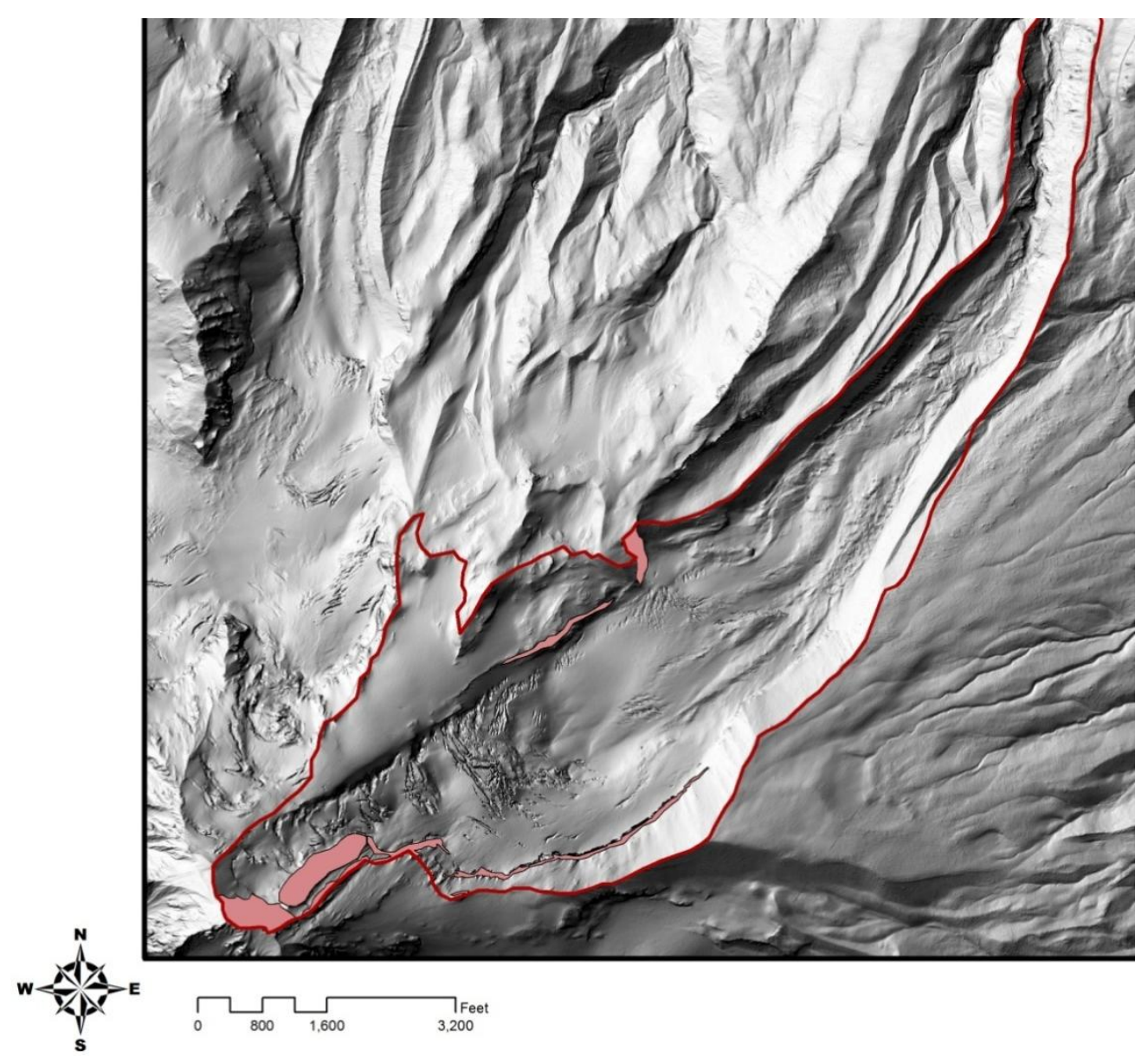

Figure 62. Eliot Creek bedrock (3.4\%) 


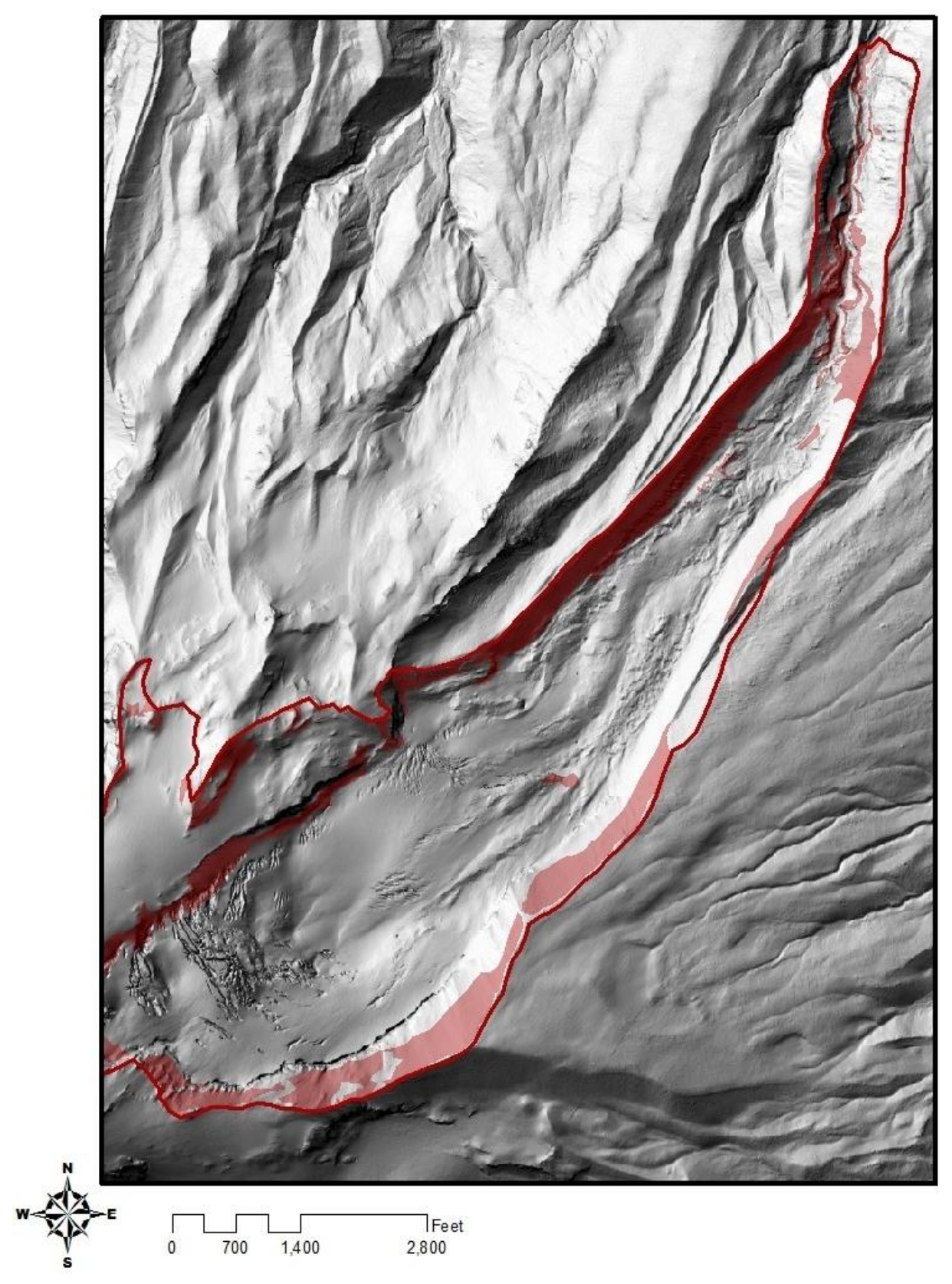

Figure 63. Eliot Creek steep slopes (18.2\%) 
APPENDIX B: $\quad$ SANDY RIVER DRAINAGE BASIN

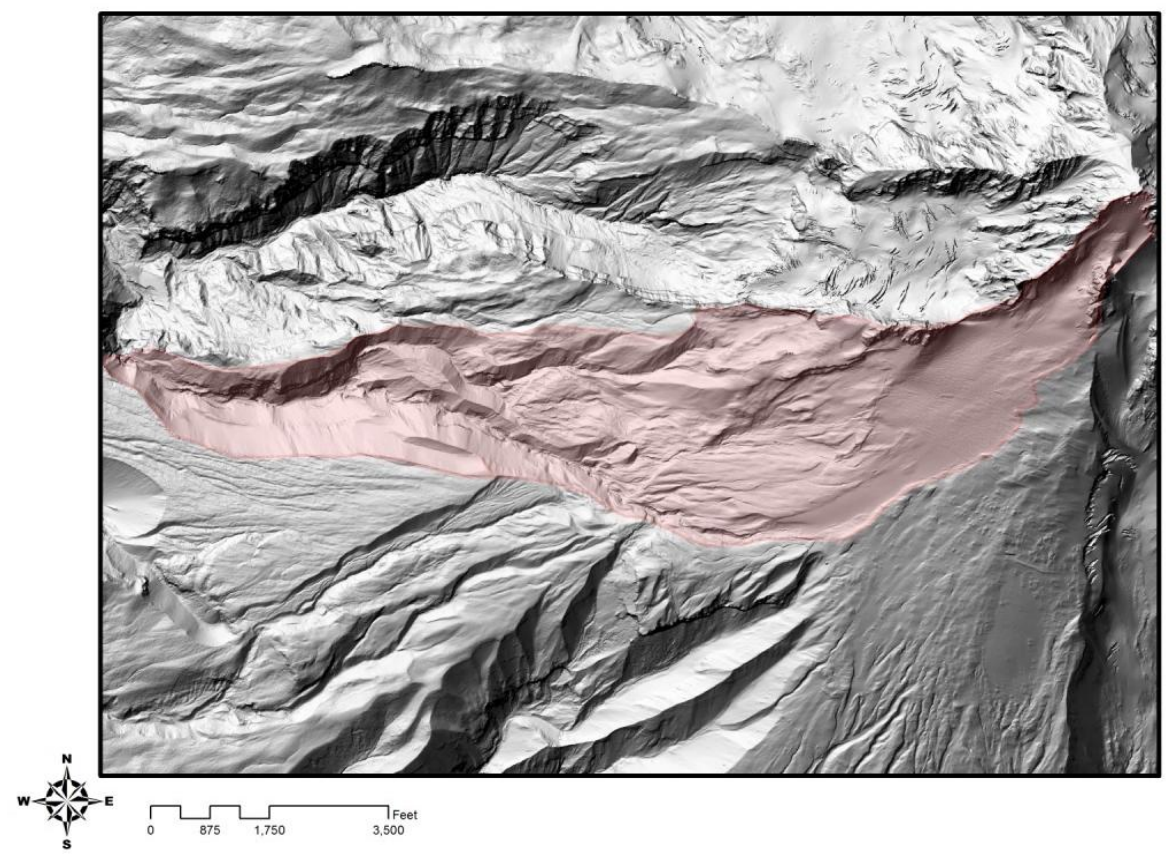

Figure 64. Sandy River upper drainage basin $\left(3,065,379 \mathrm{~m}^{2}\right)$

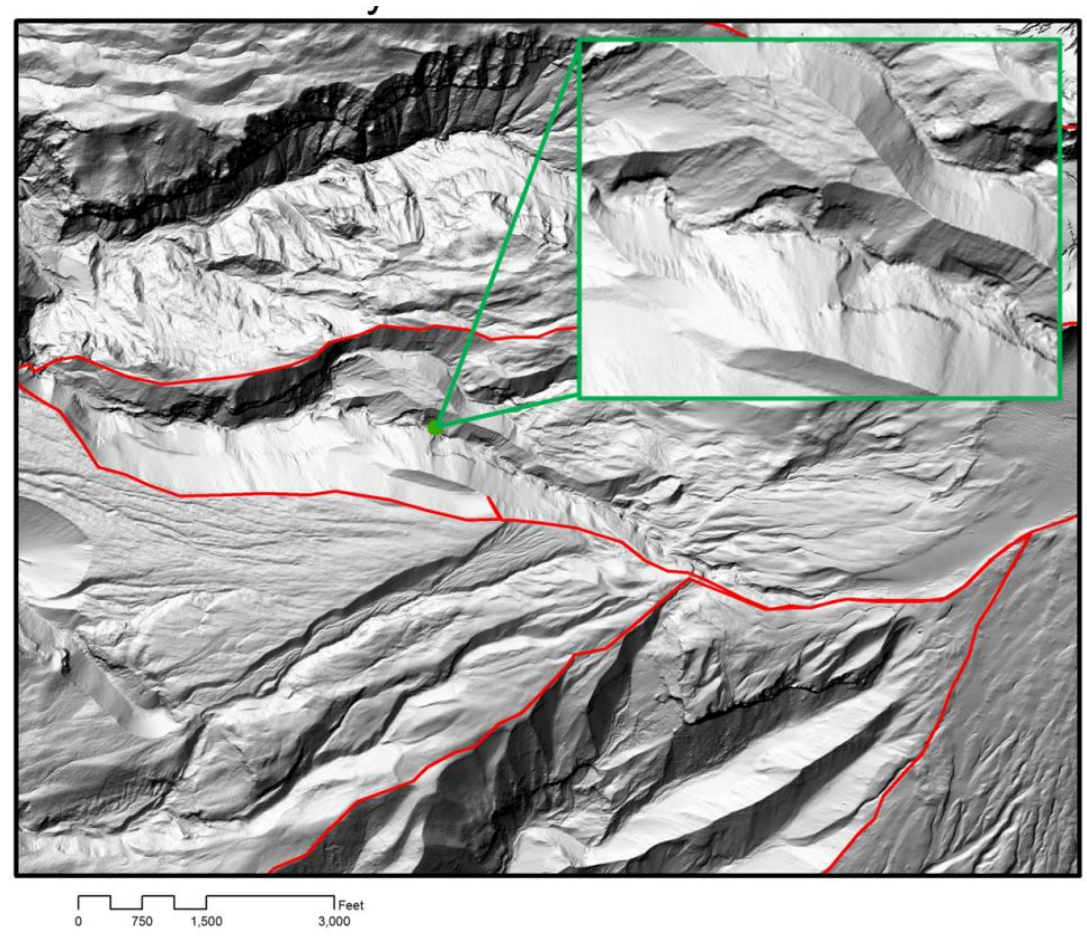

Figure 65. Sandy River initiation zone 


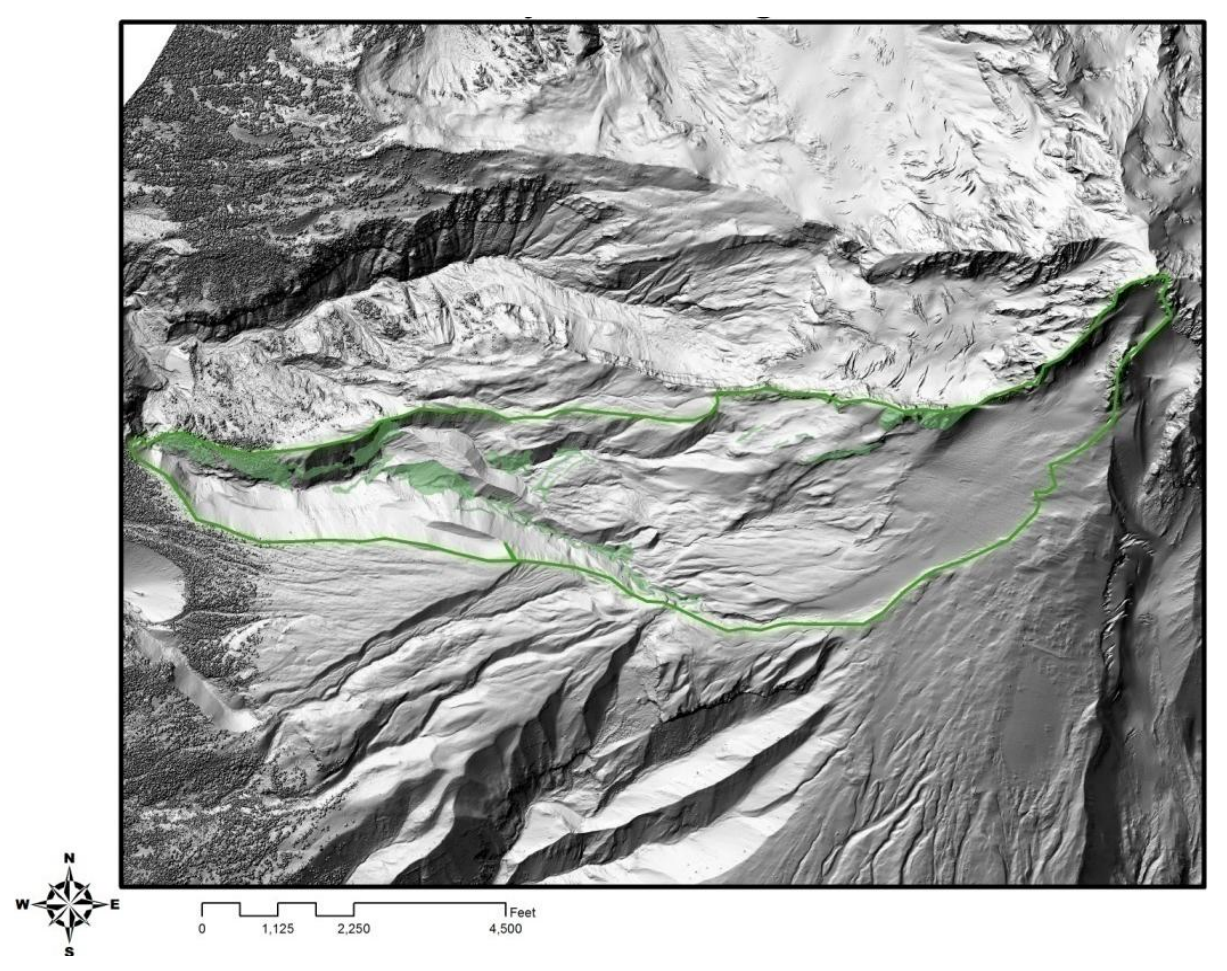

Figure 66. Sandy River vegetation (7.5\%)

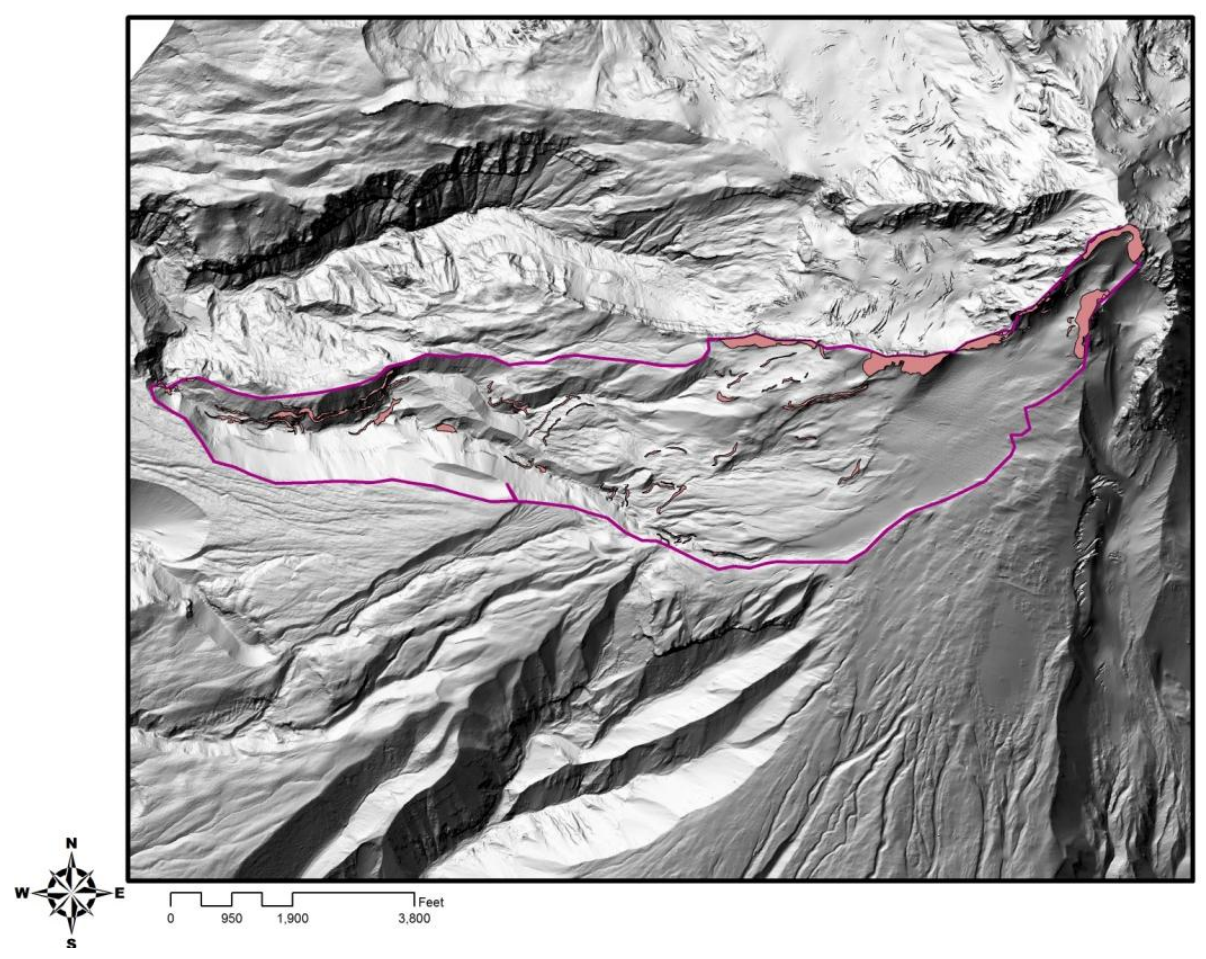

Figure 67. Sandy River bedrock (5.0\%) 


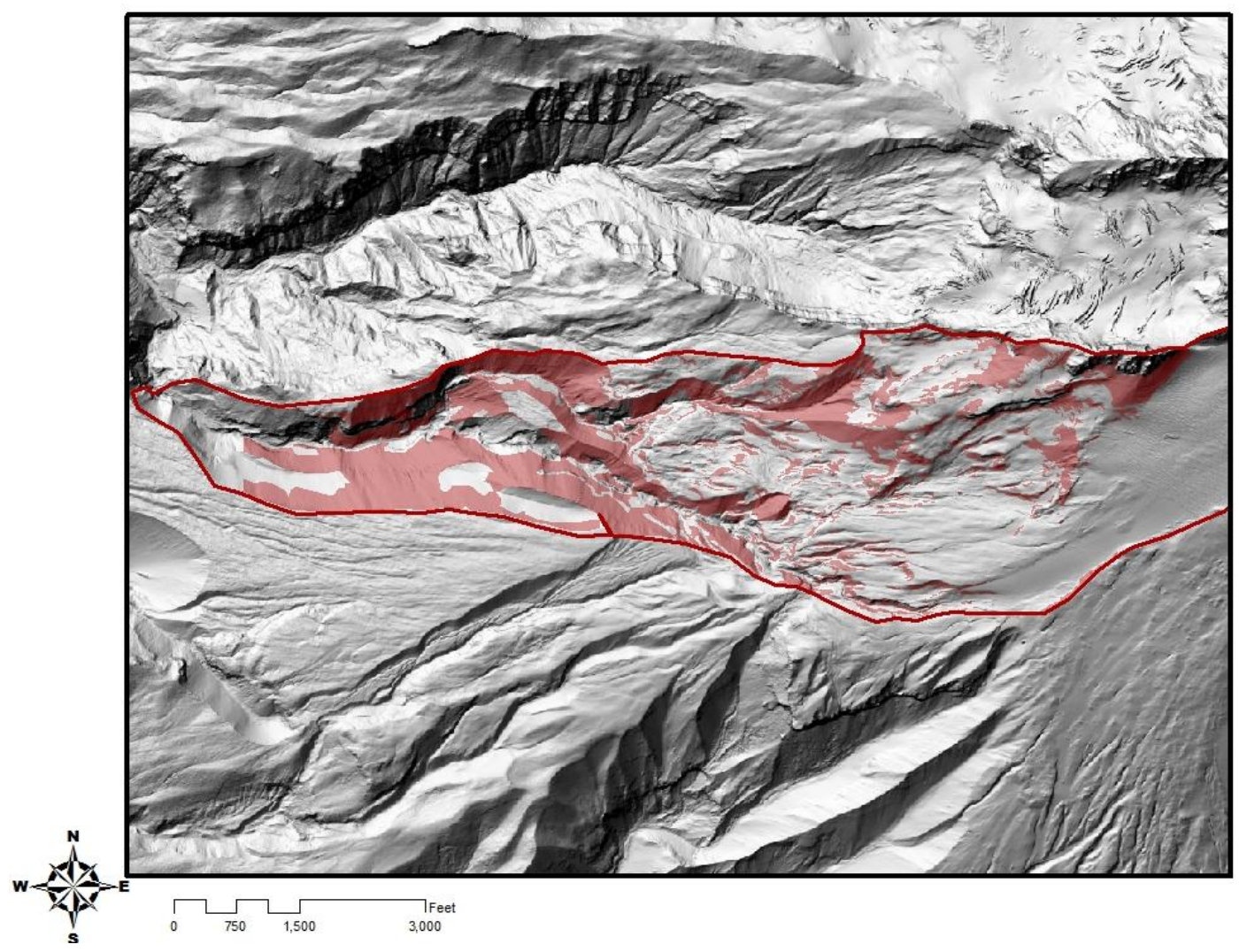

Figure 68. Sandy River steep slopes (29.5\%) 
APPENDIX C: $\quad$ WHITE RIVER DRAINAGE BASIN

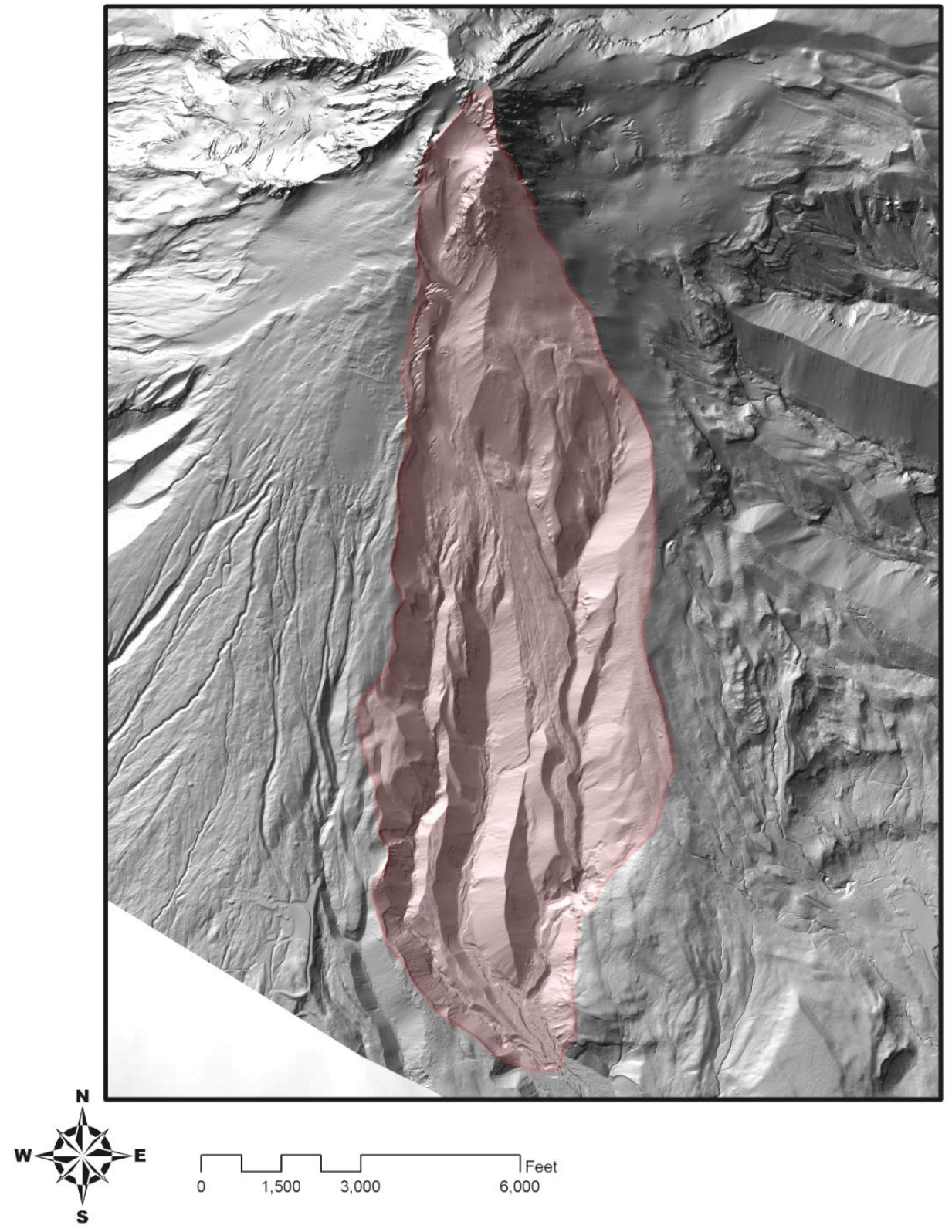

Figure 69. White River upper drainage basin $\left(6,523,258 \mathrm{~m}^{2}\right)$ 


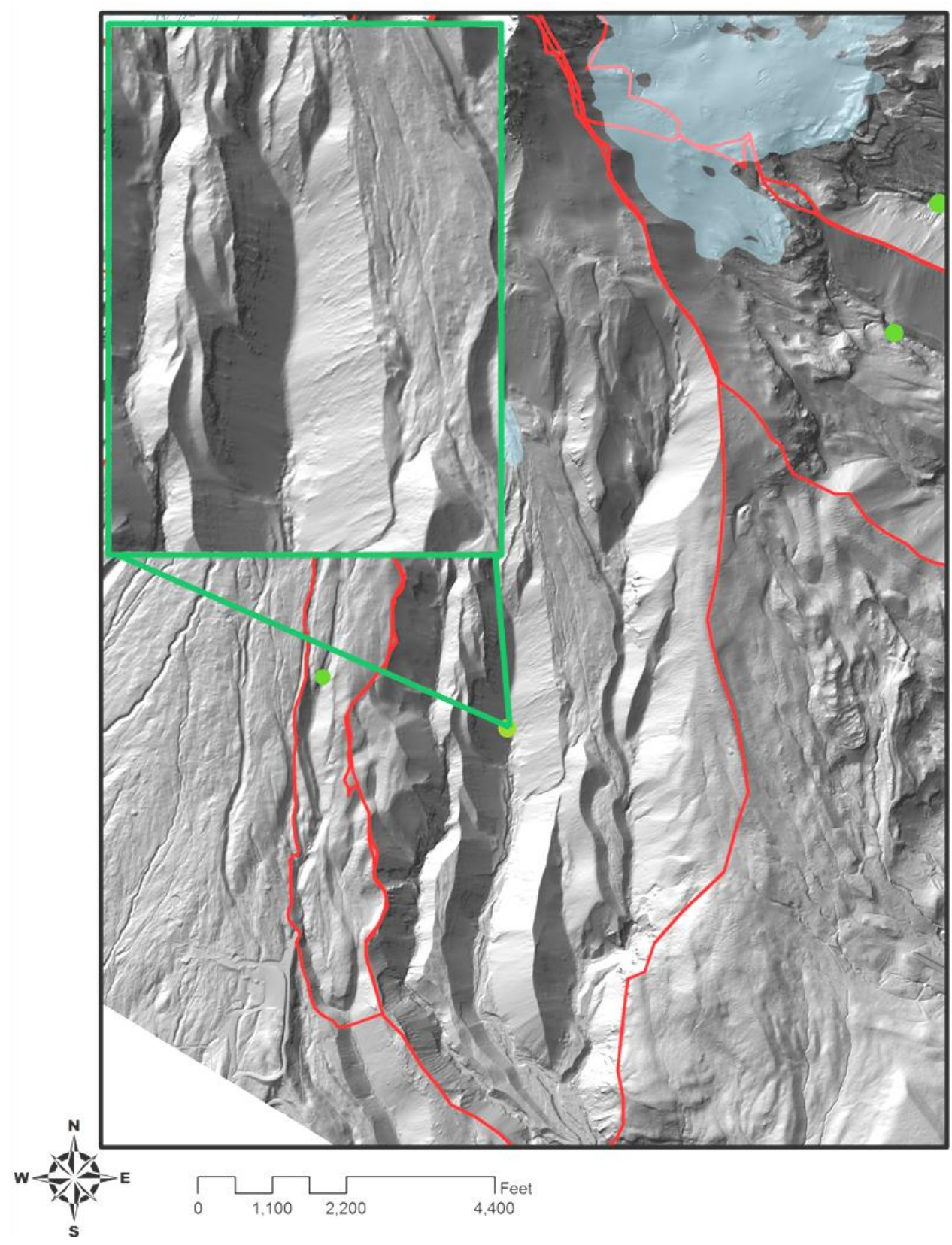

Figure 70. White River initiation zone 


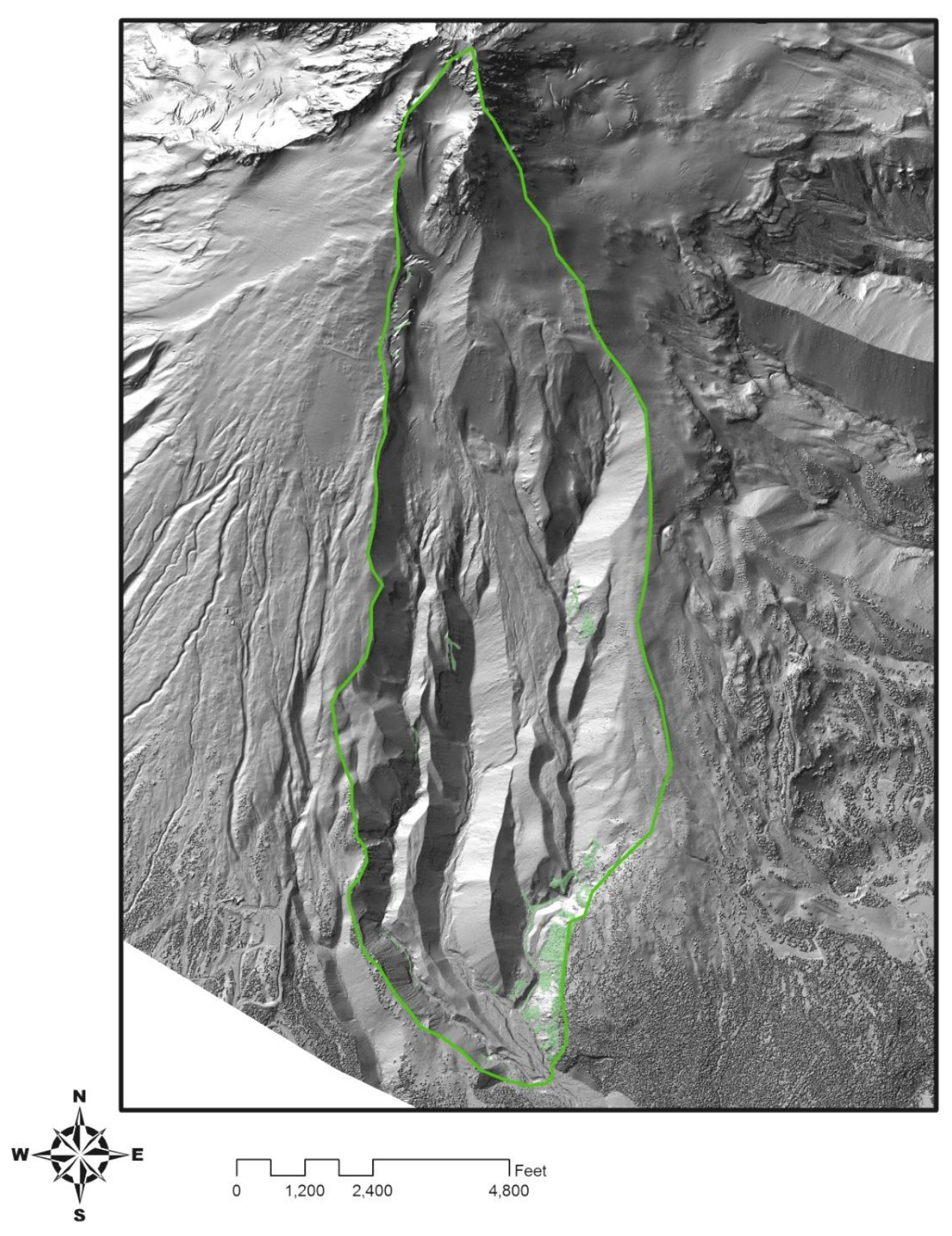

Figure 71. White River vegetation (2.0\%) 


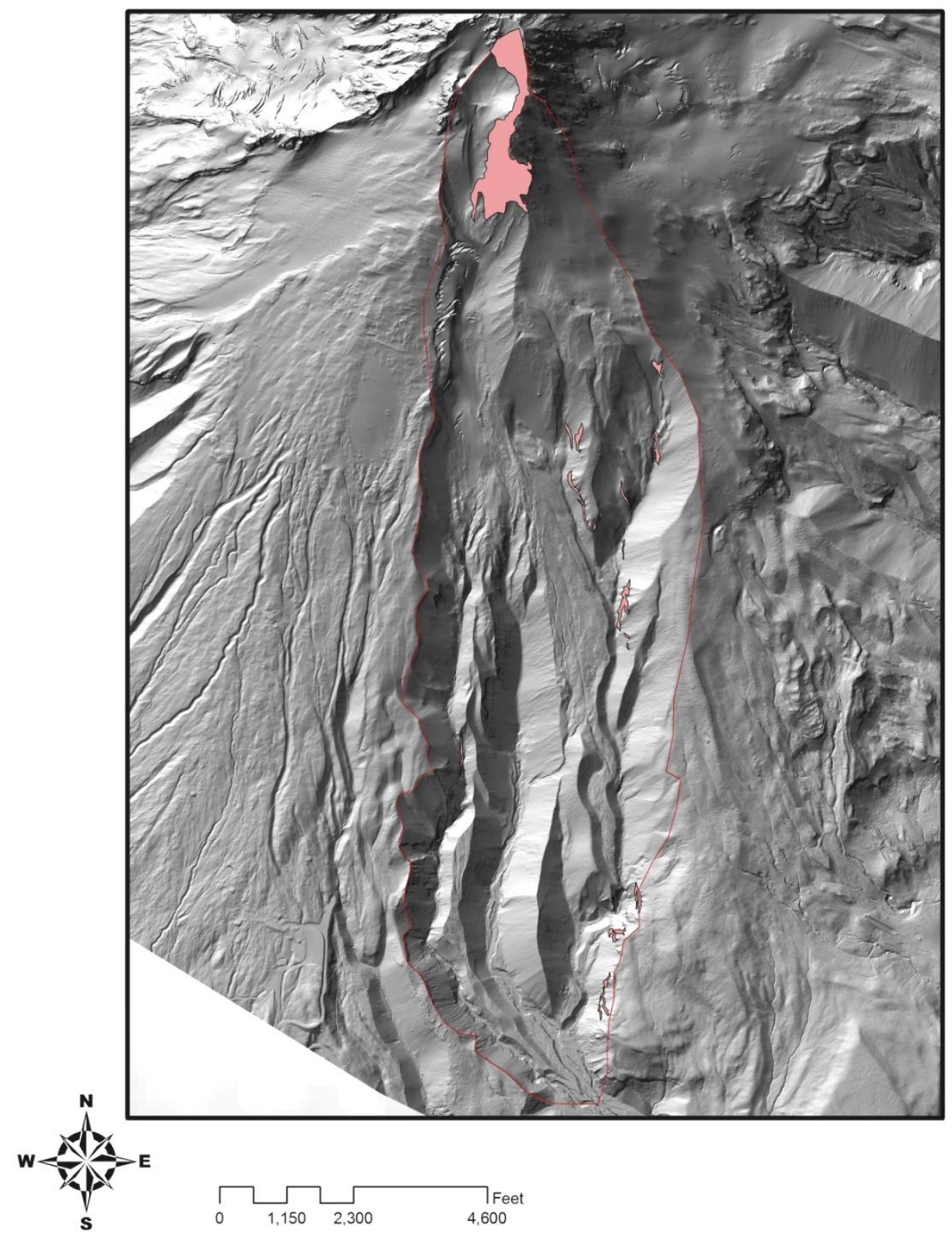

Figure 72. White River bedrock (2.5\%) 


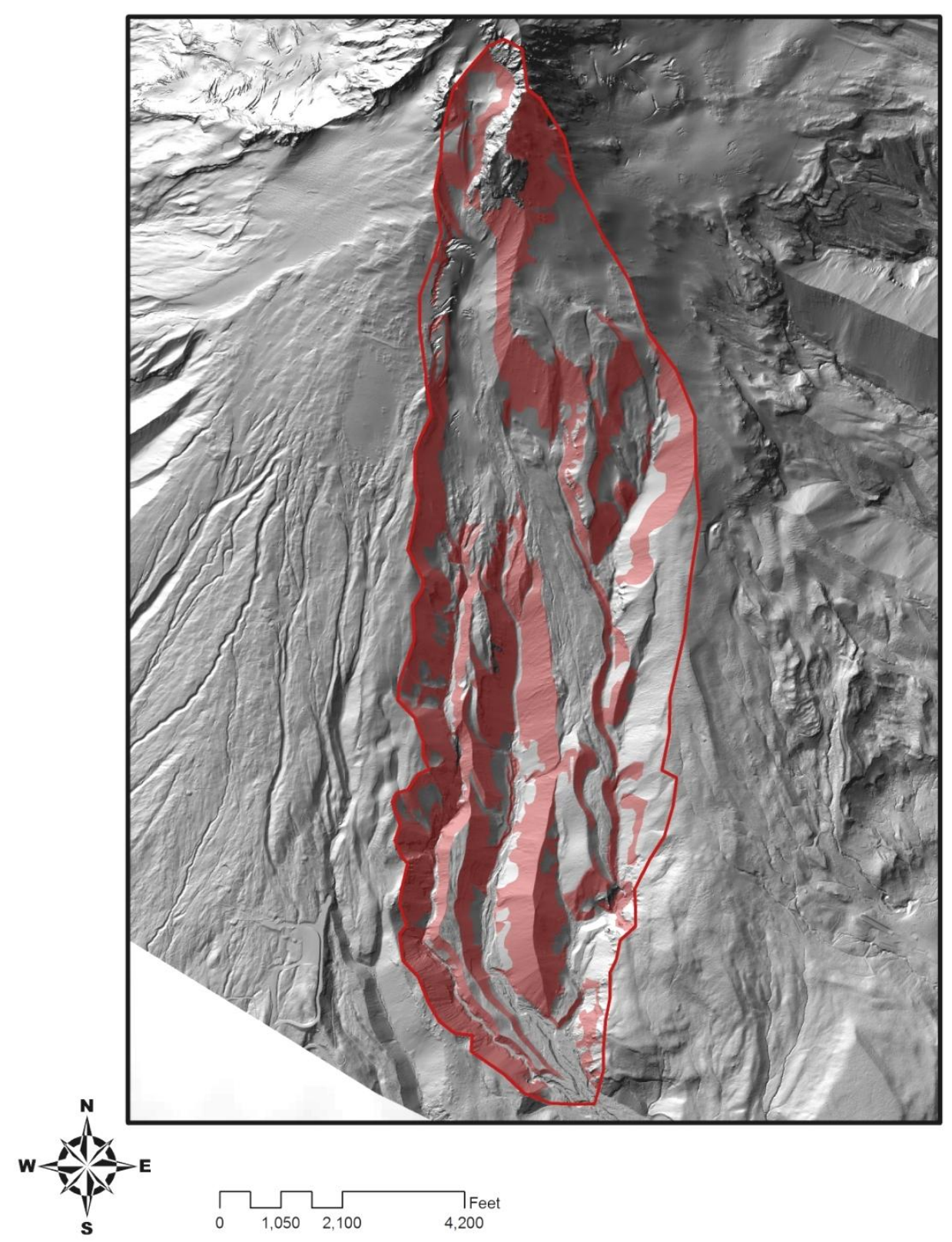

Figure 73. White River steep slopes (41.5\%) 
APPENDIX D: NEWTON CREEK DRAINAGE BASIN

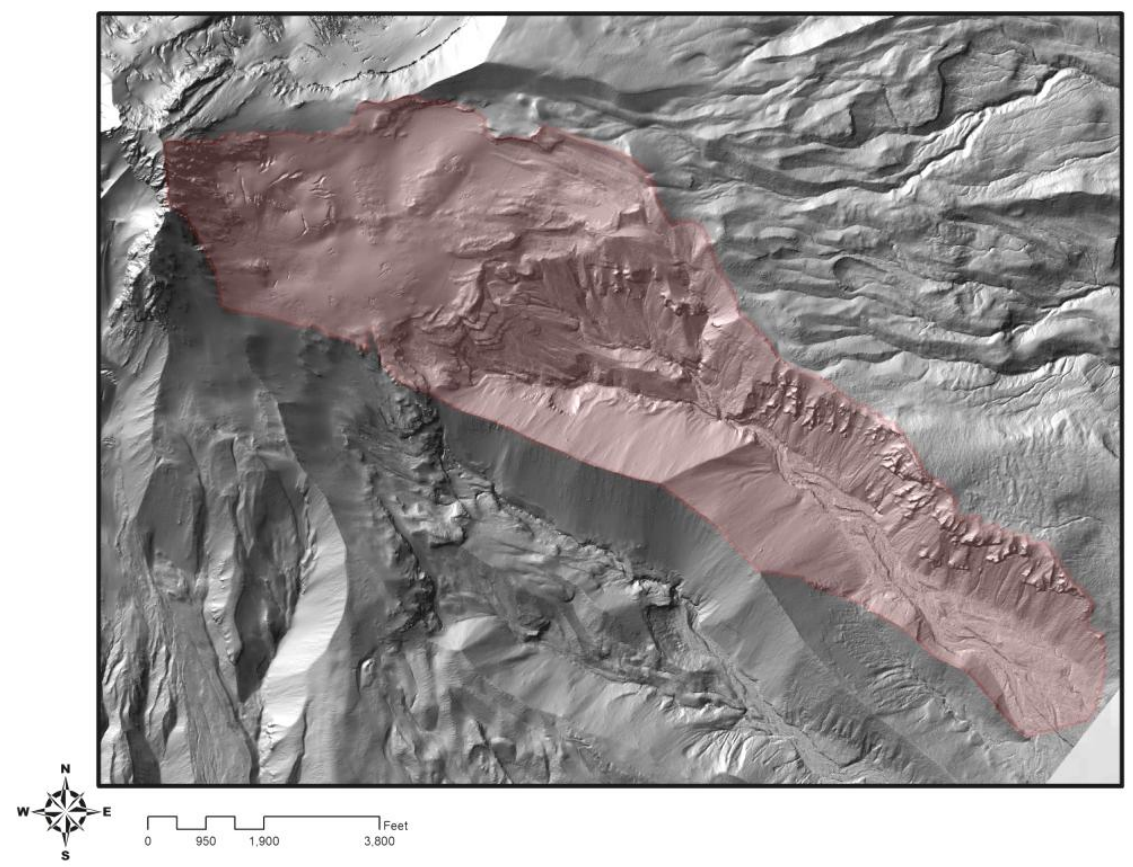

Figure 74. Newton Creek upper drainage basin $\left(5,282,798 \mathrm{~m}^{2}\right)$

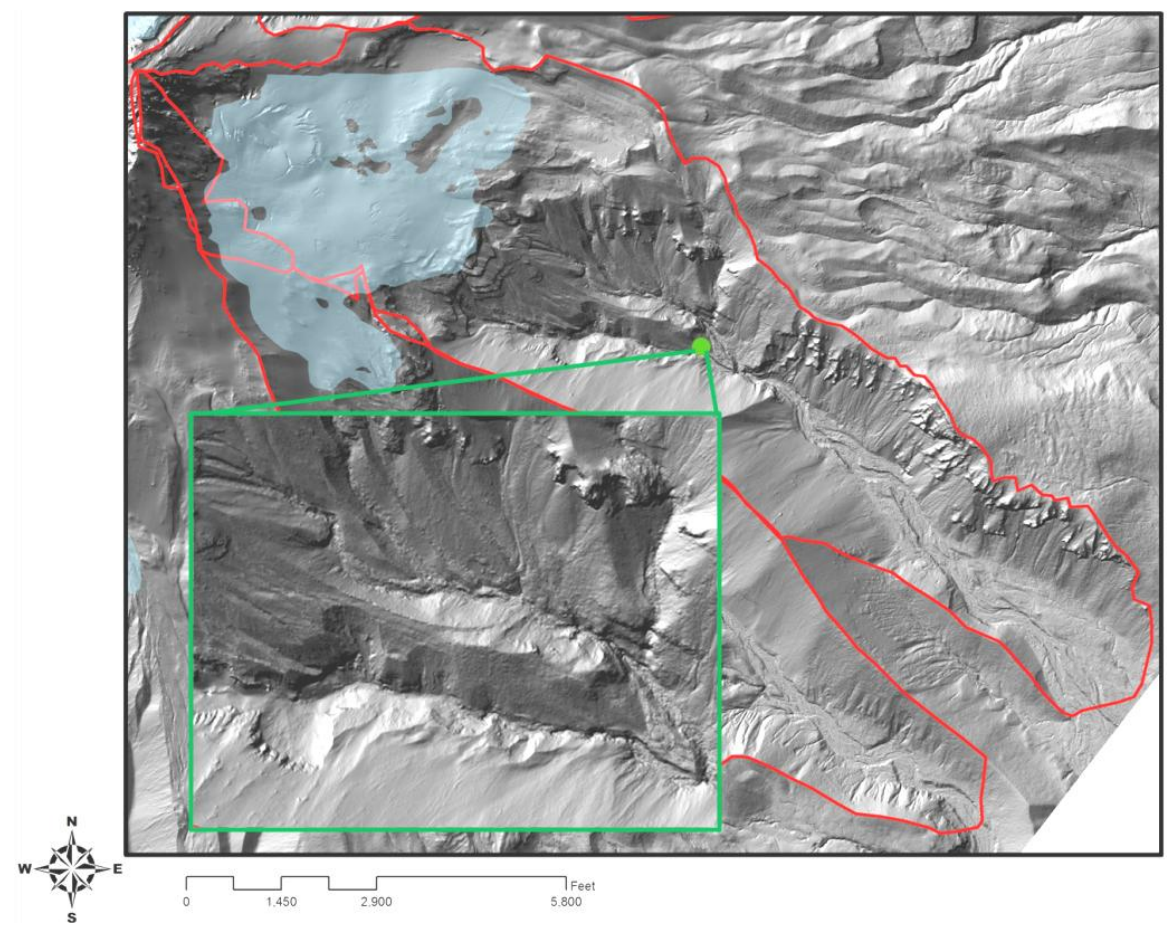

Figure 75. Newton Creek initiation zone 


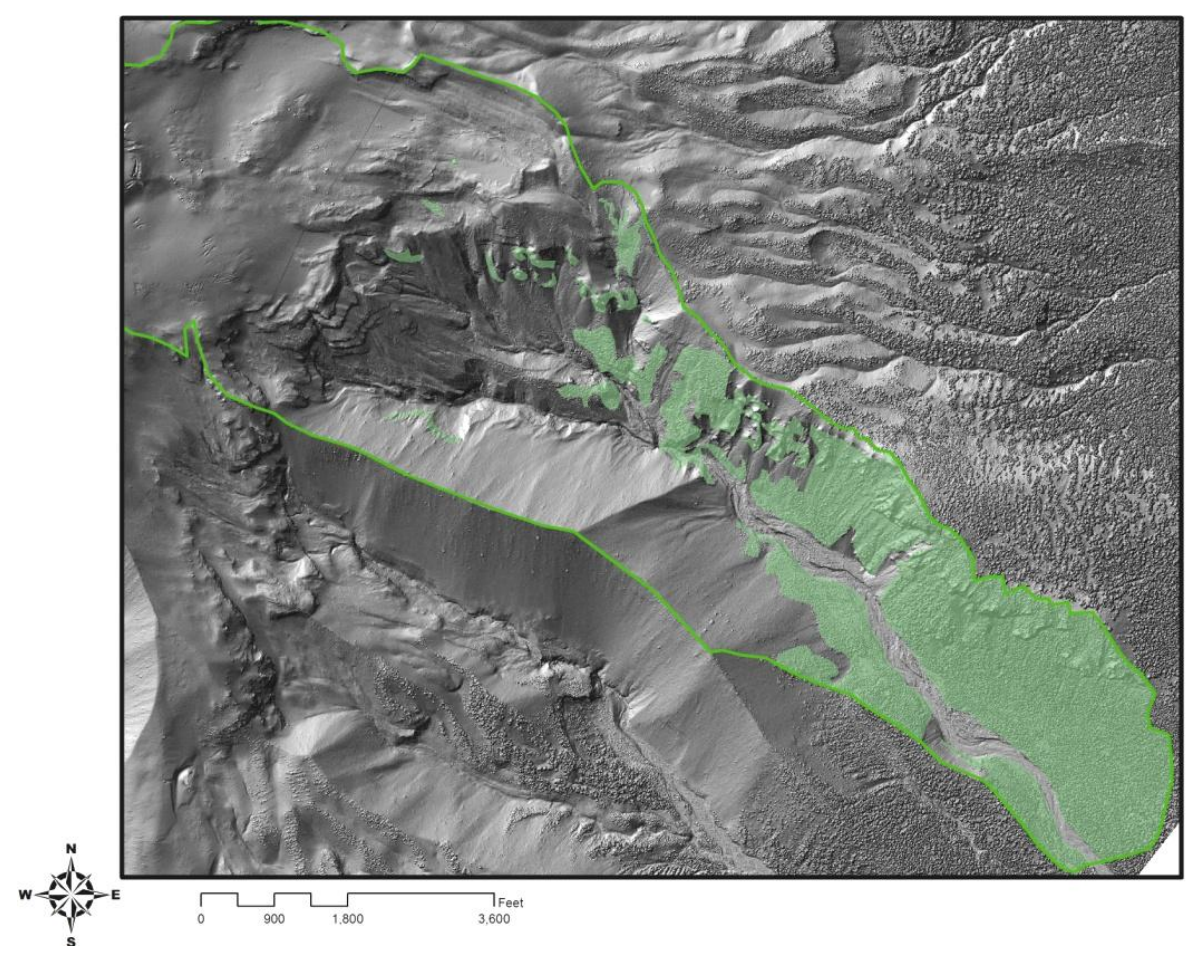

Figure 76. Newton Creek vegetation (24.2\%)

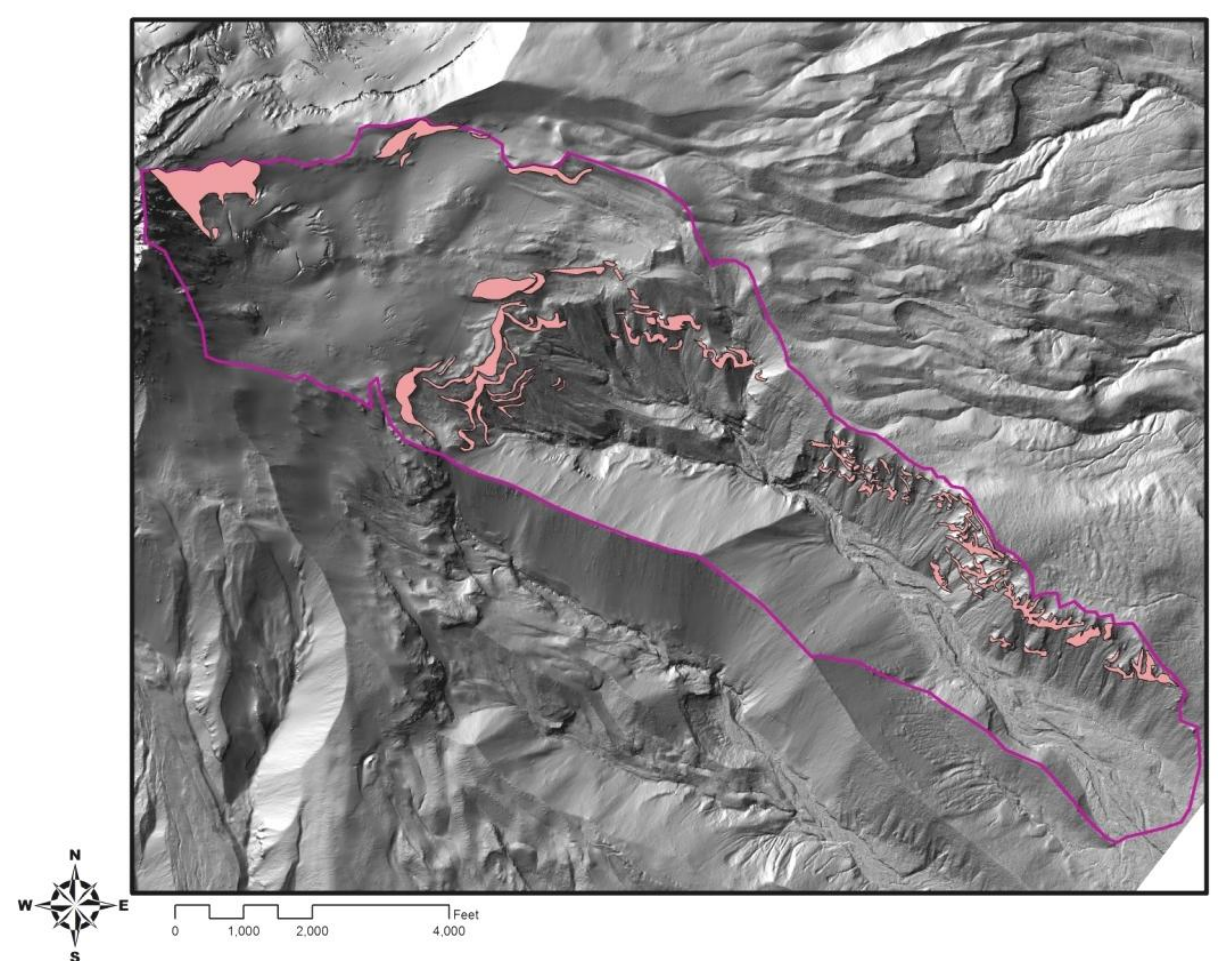

Figure 77. Newton Creek bedrock (6.5\%) 


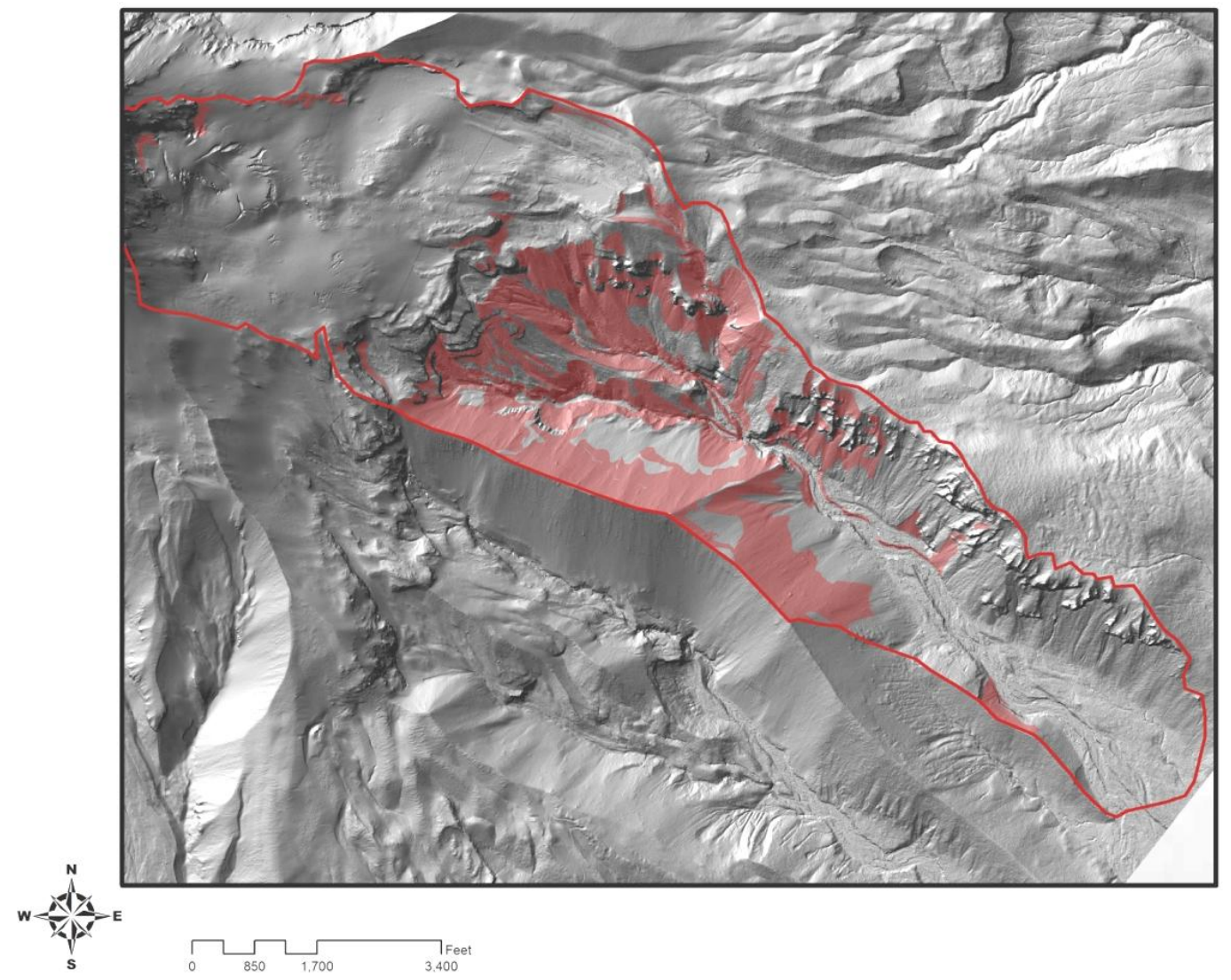

Figure 78. Newton Creek steep slopes (23.0\%) 
APPENDIX E: $\quad$ CLARK CREEK DRAINAGE BASIN

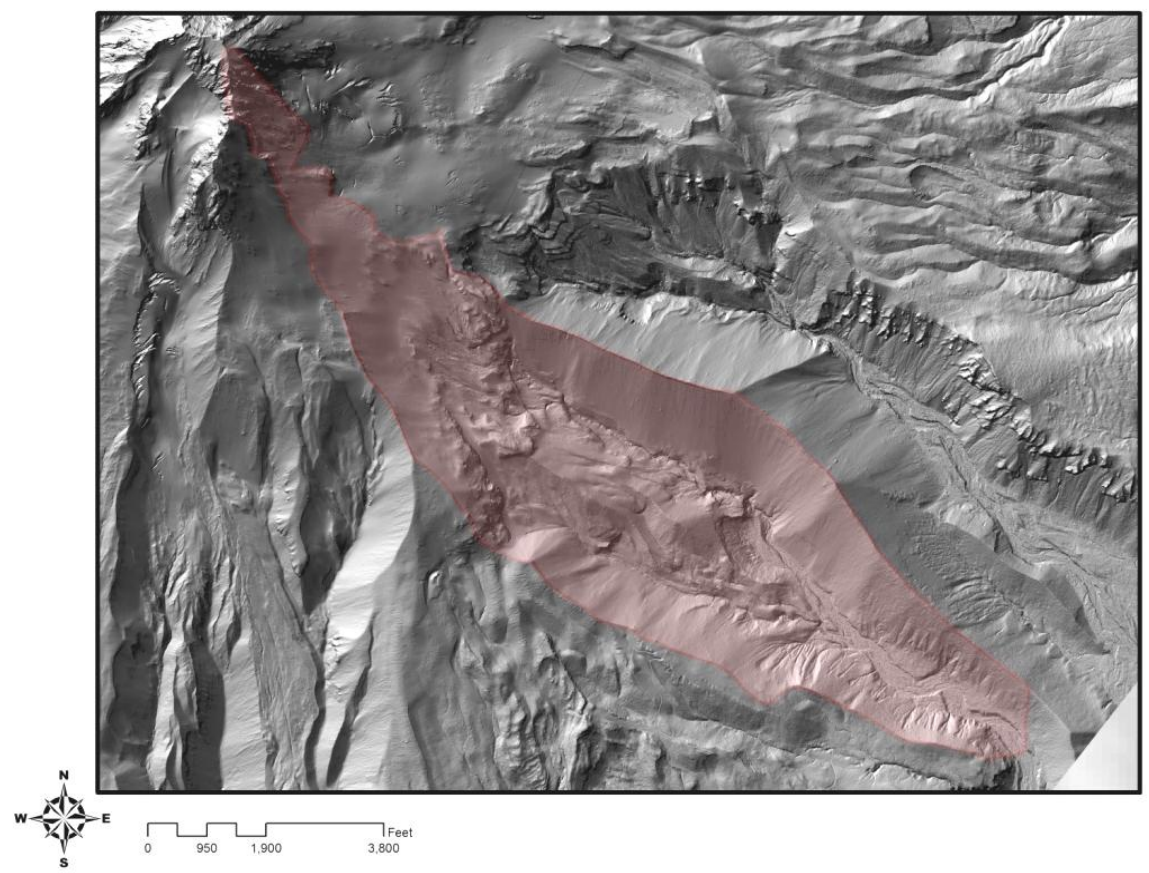

Figure 79. Clark Creek upper drainage basin $\left(3,879,433 \mathrm{~m}^{2}\right)$

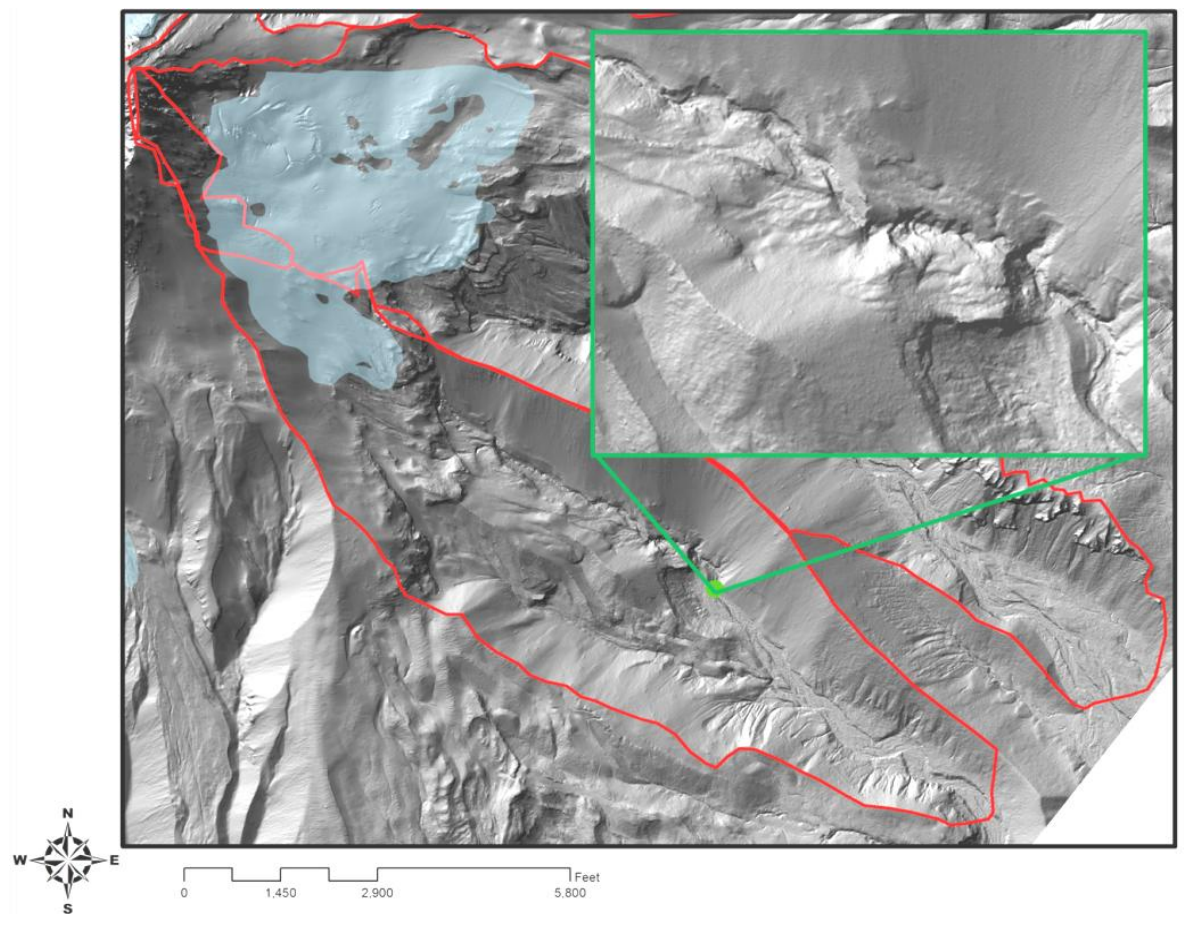

Figure 80. Clark creek initiation zone 


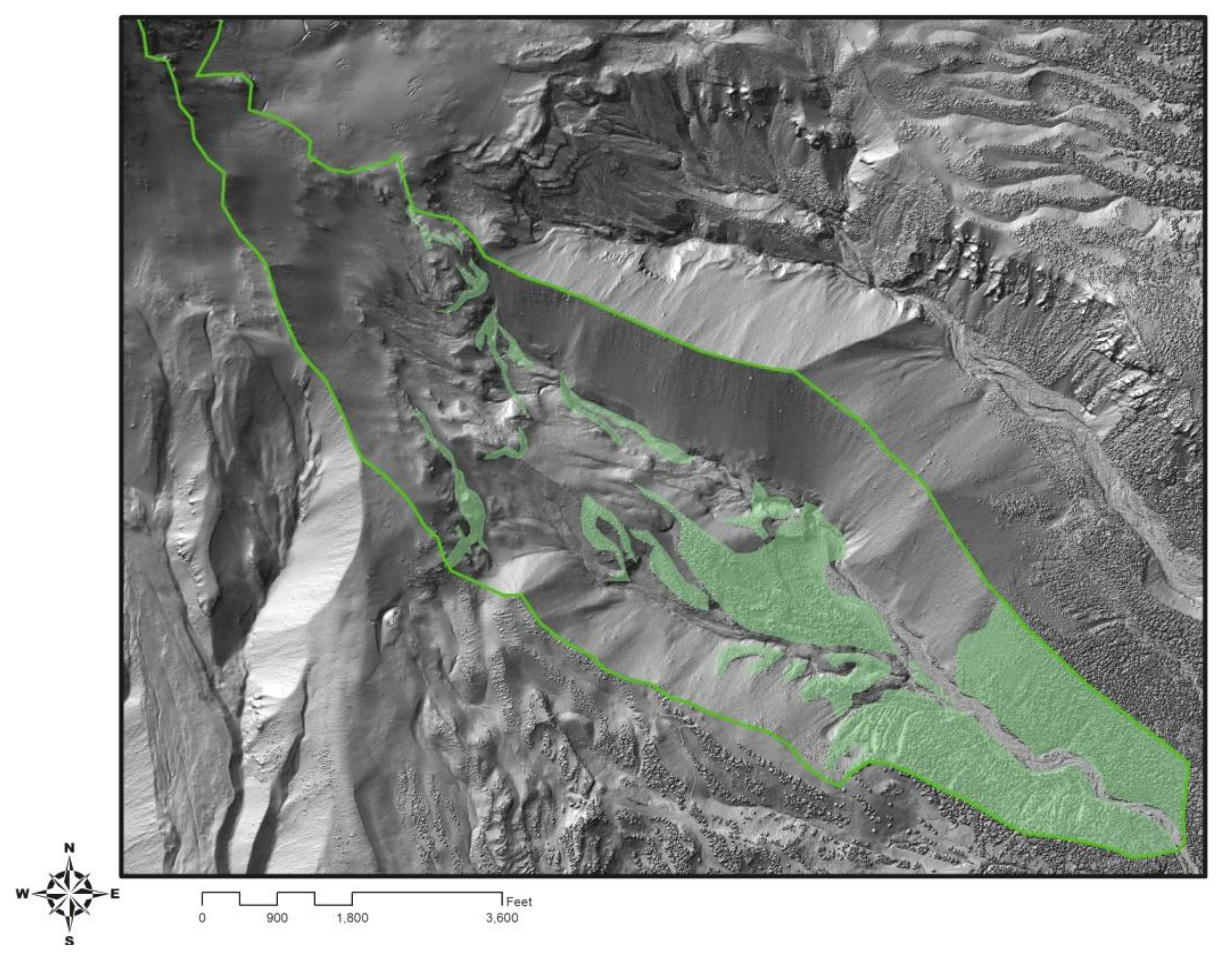

Figure 81. Clark Creek vegetation (26.7\%)

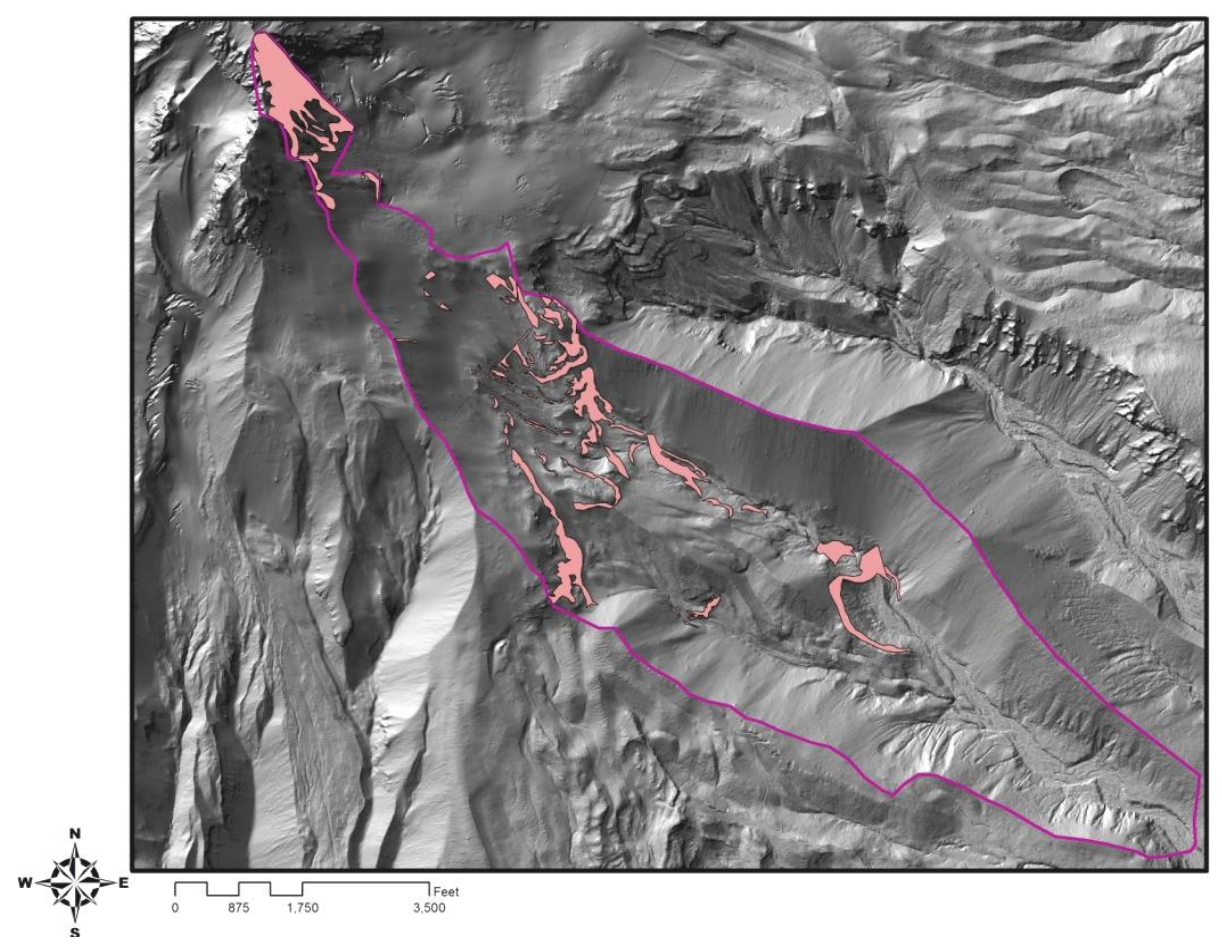

Figure 82. Clark Creek bedrock (7.5\%) 


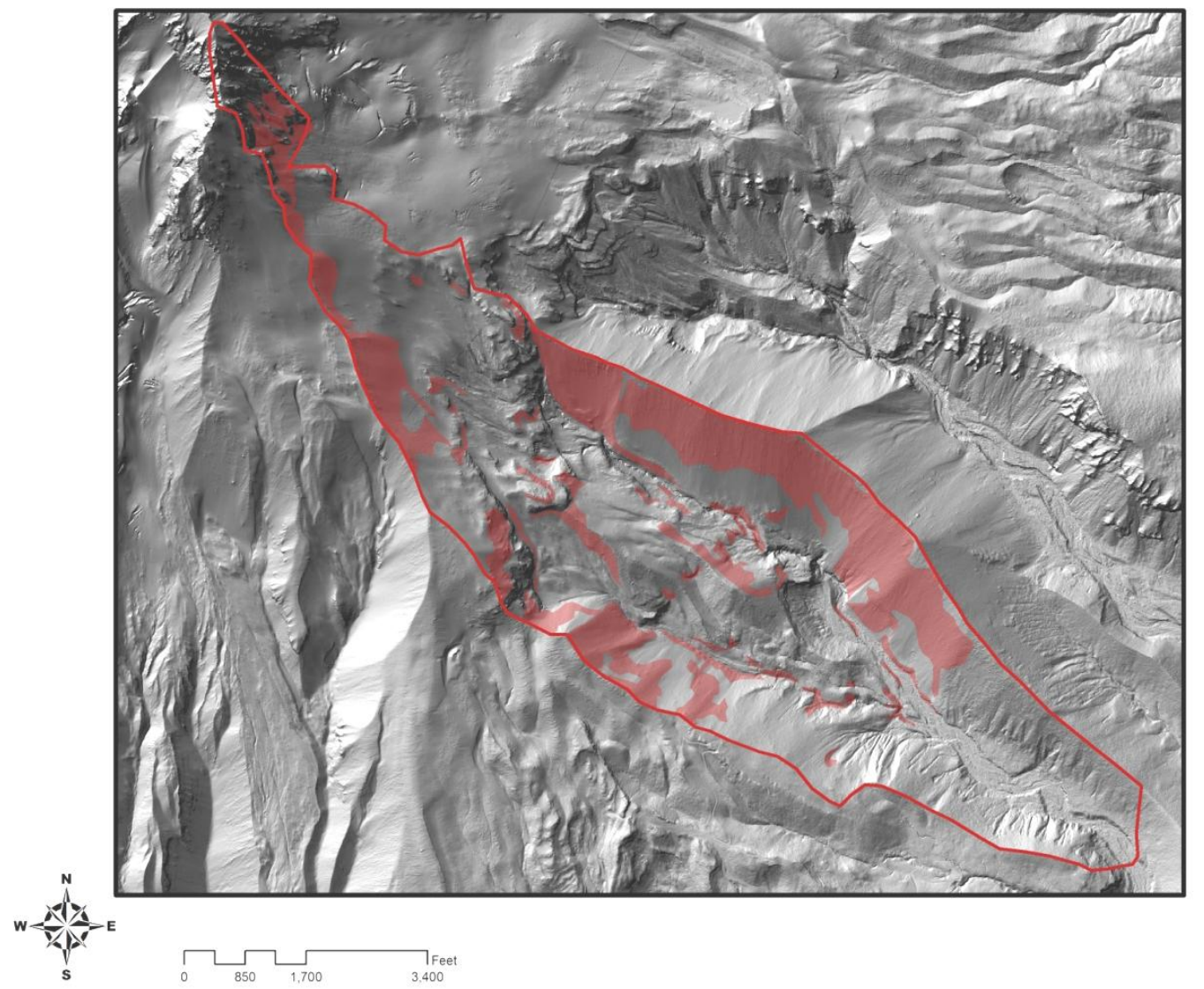

Figure 83. Clark Creek steep slopes (26.6\%) 
APPENDIX F: $\quad$ SALMON RIVER DRAINAGE BASIN

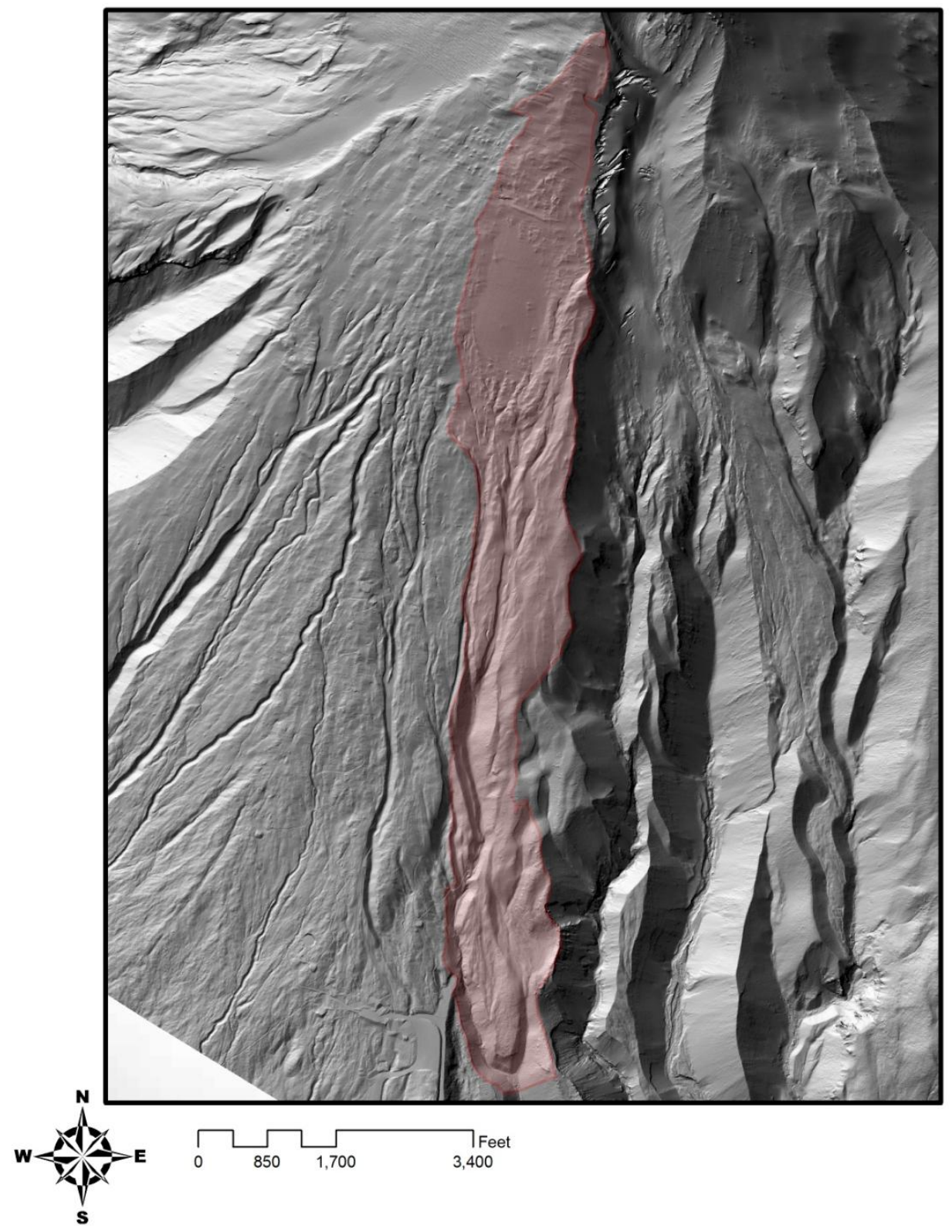

Figure 84. Salmon River upper drainage basin $\left(1,376,945 \mathrm{~m}^{2}\right)$ 


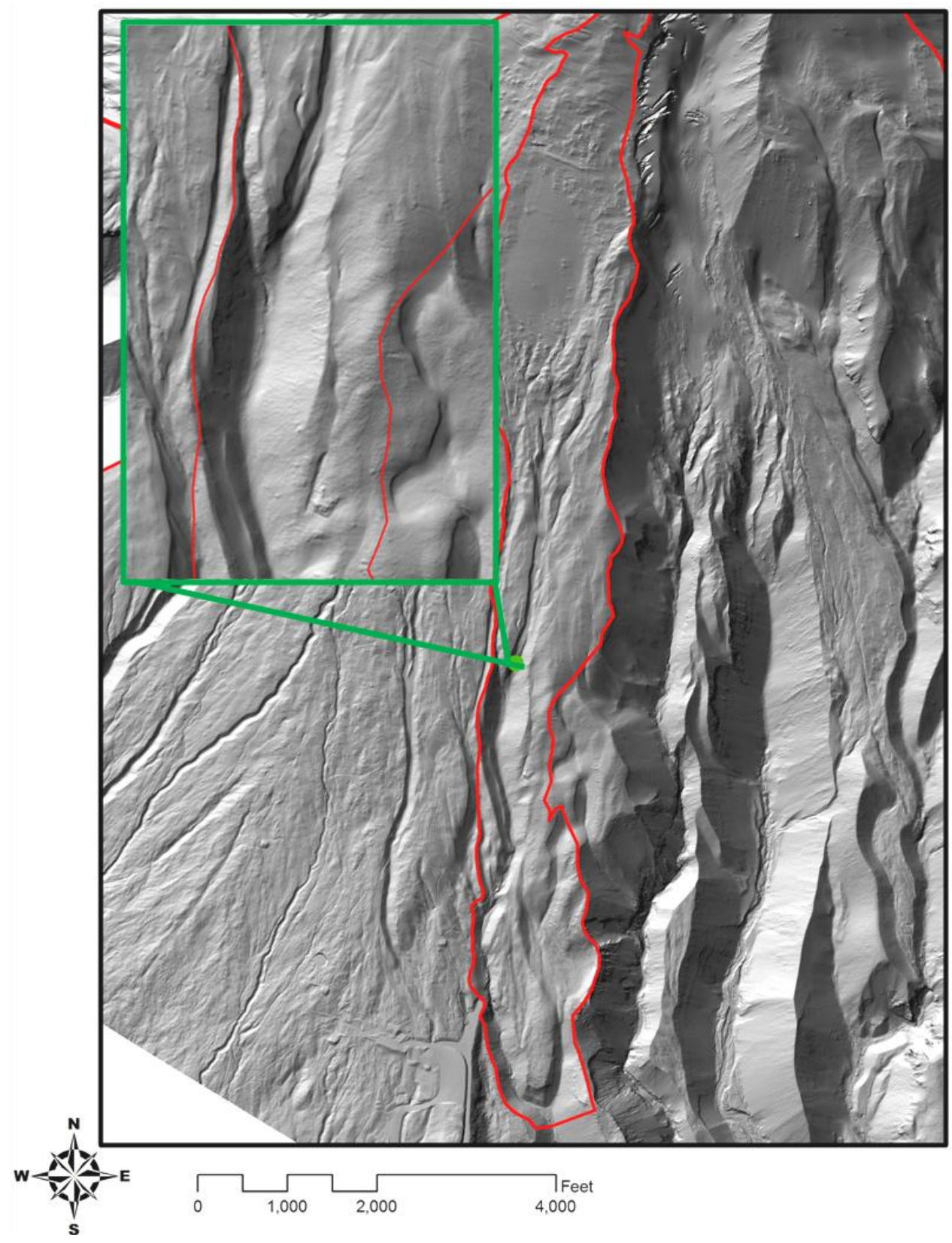

Figure 85. Salmon River initiation zone 


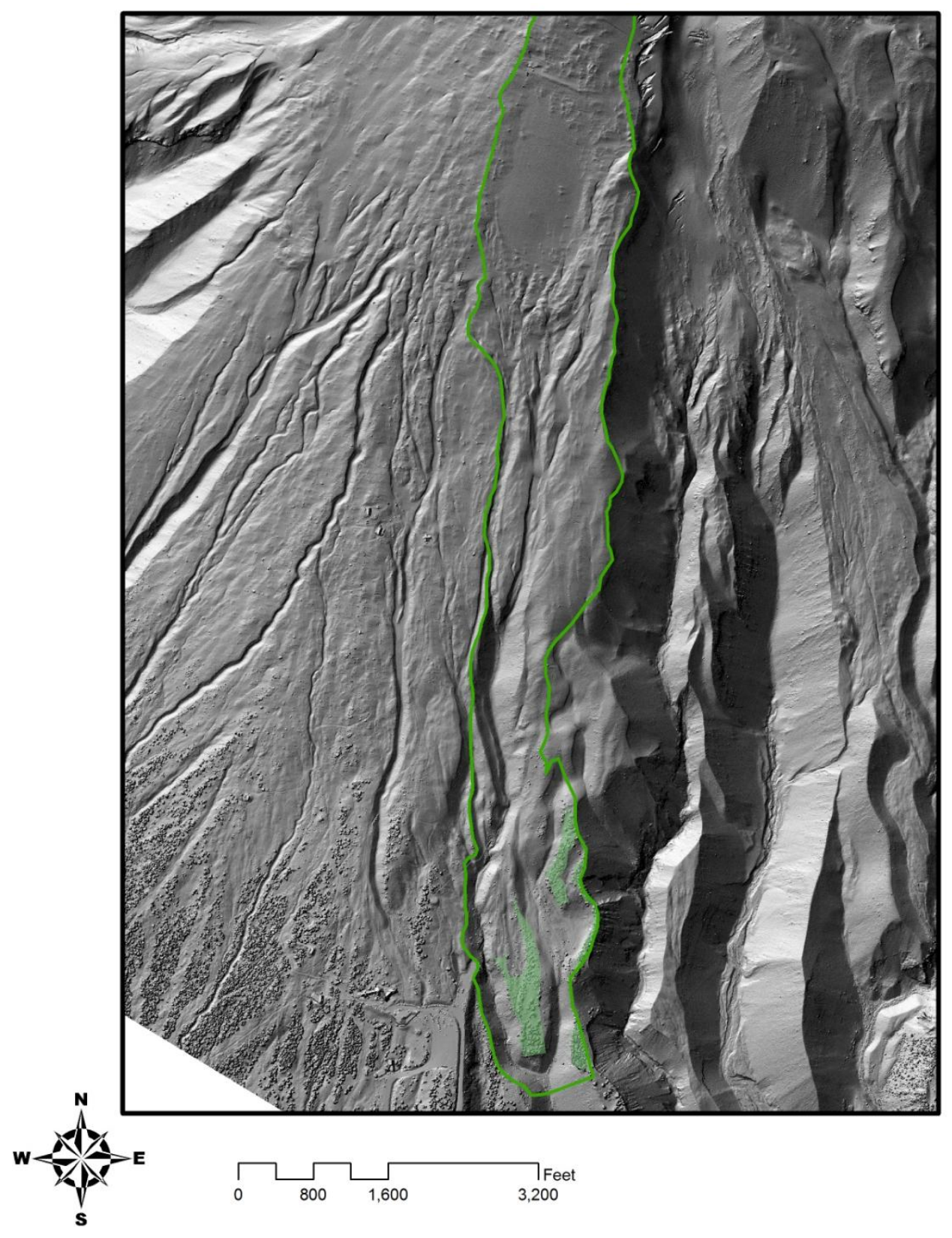

Figure 86. Salmon River vegetation (4.1\%) 


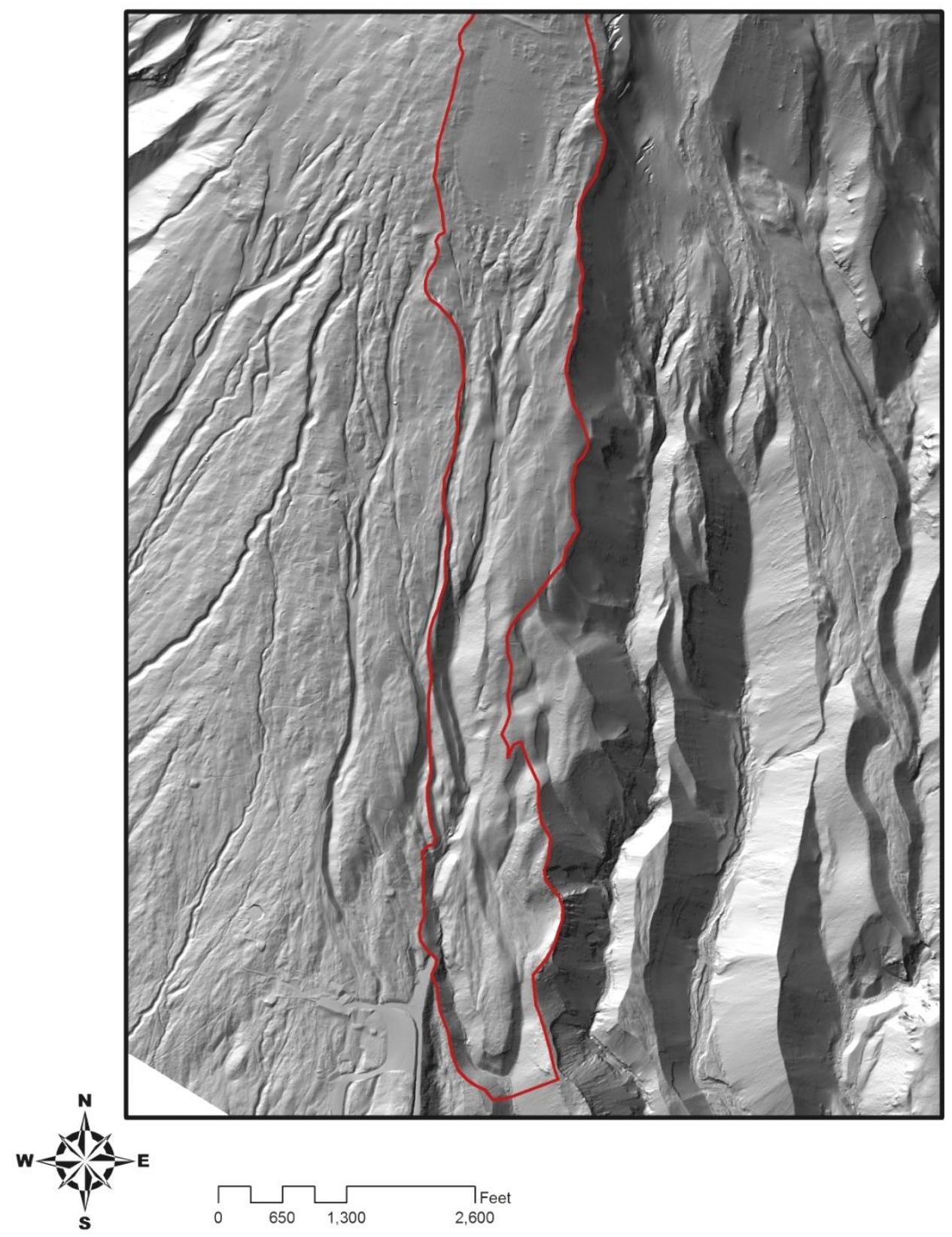

Figure 87. Salmon River bedrock (0.0\%) 


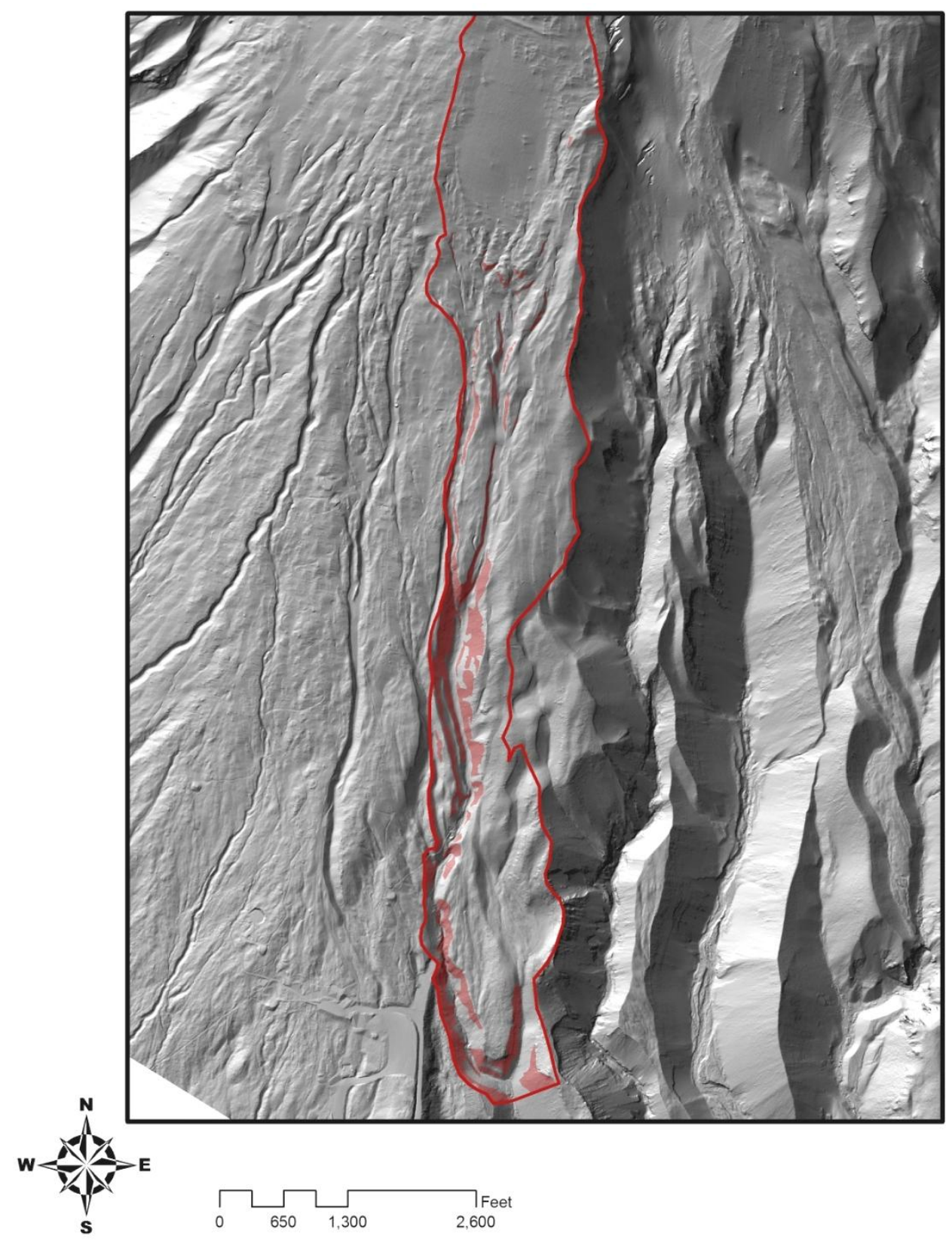

Figure 88. Salmon River steep slopes (9.3\%) 
APPENDIX G: $\quad$ LADD CREEK DRAINAGE BASIN

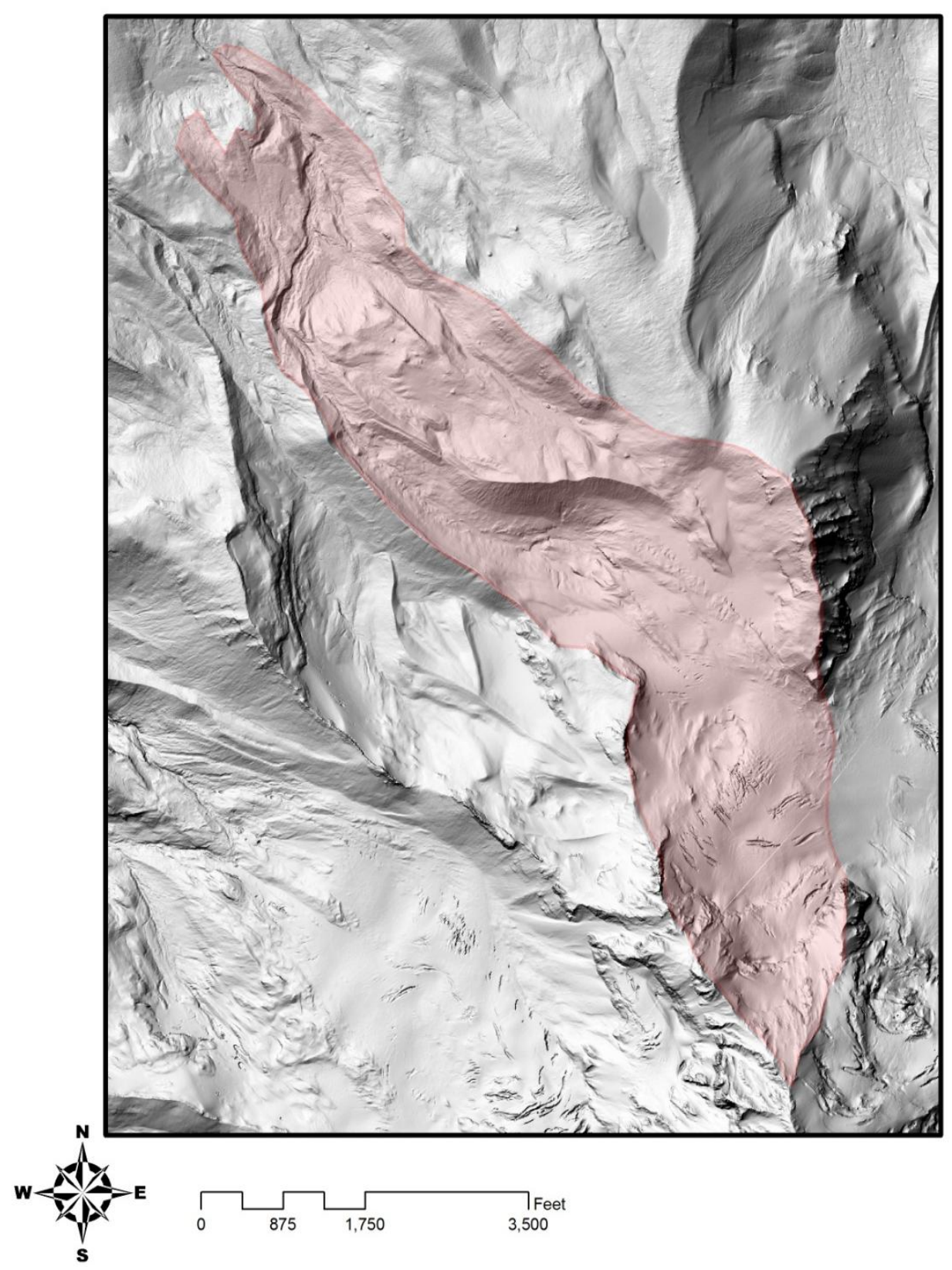

Figure 89. Ladd Creek upper drainage basin $\left(2,257,572 \mathrm{~m}^{2}\right)$ 


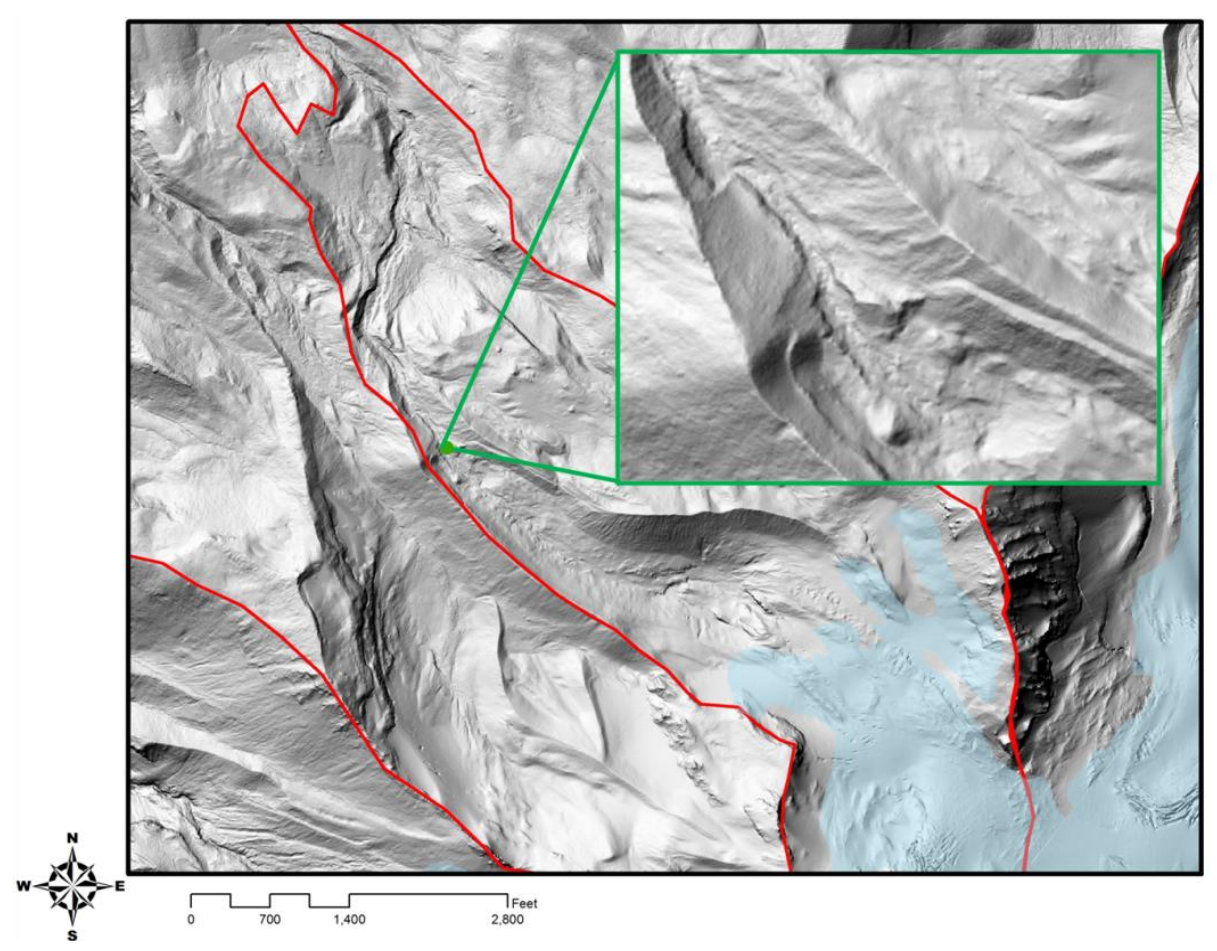

Figure 90. Ladd Creek initiation zone

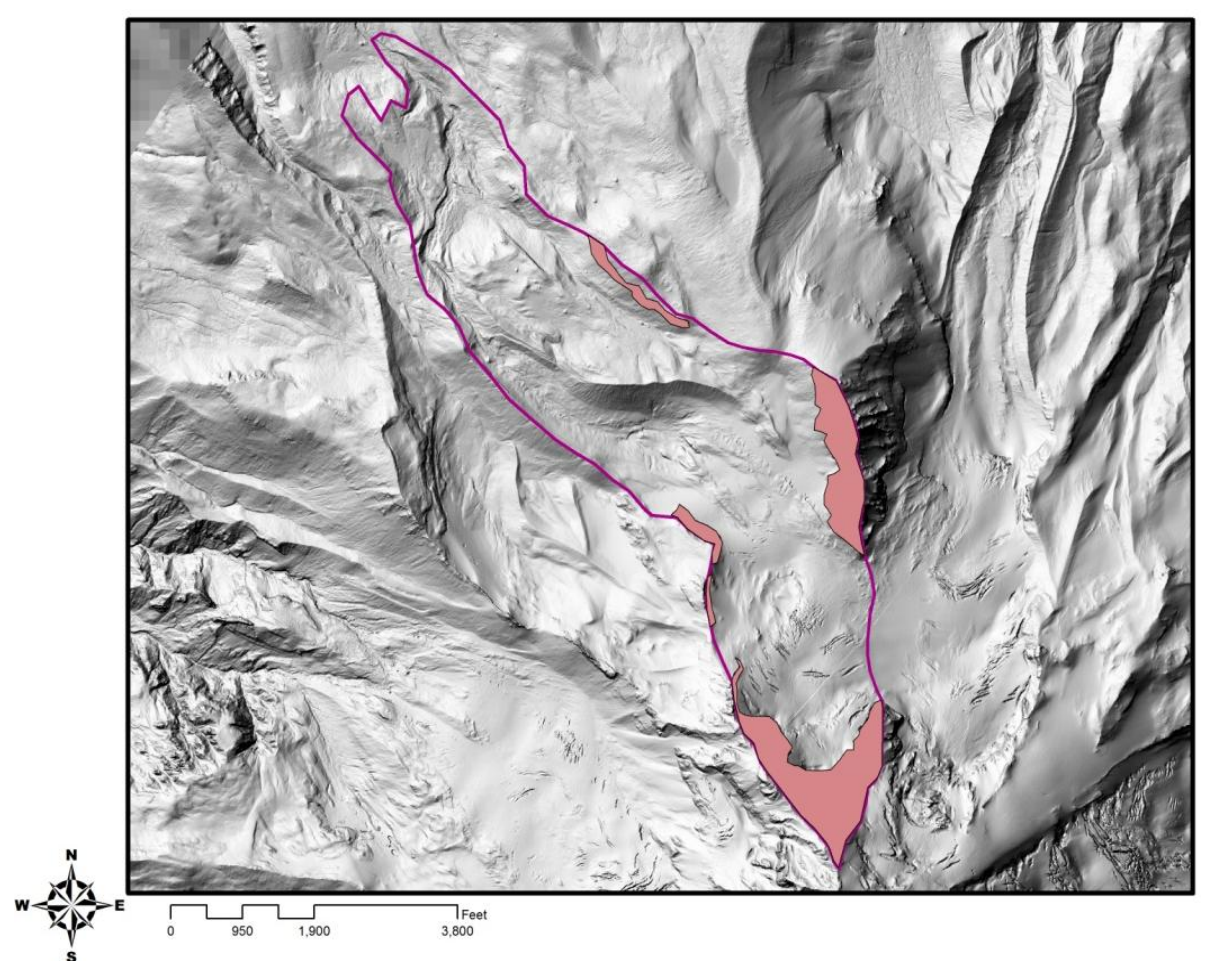

Figure 91. Ladd Creek bedrock (11.8\%) 


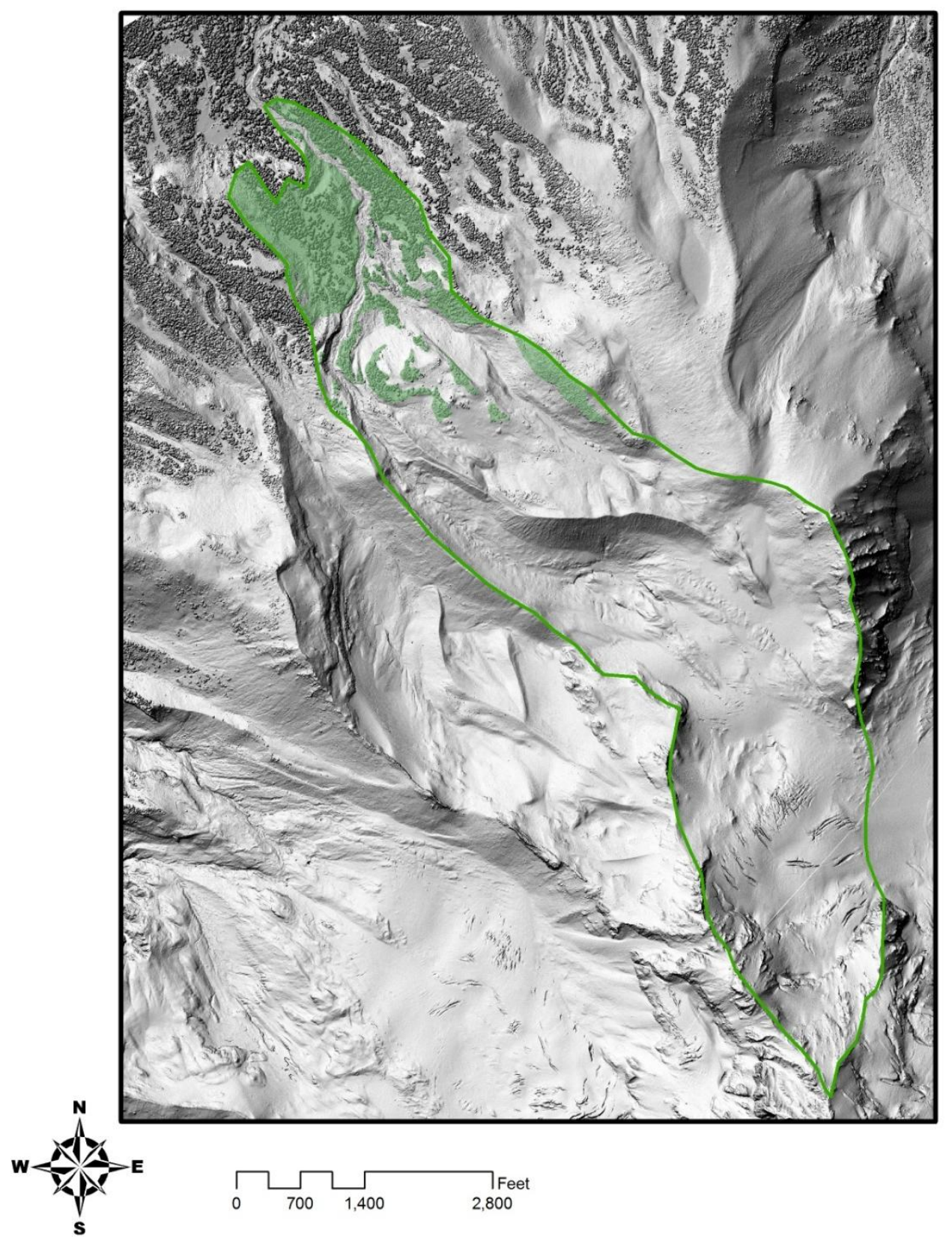

Figure 92. Ladd Creek vegetation (13.9\%) 


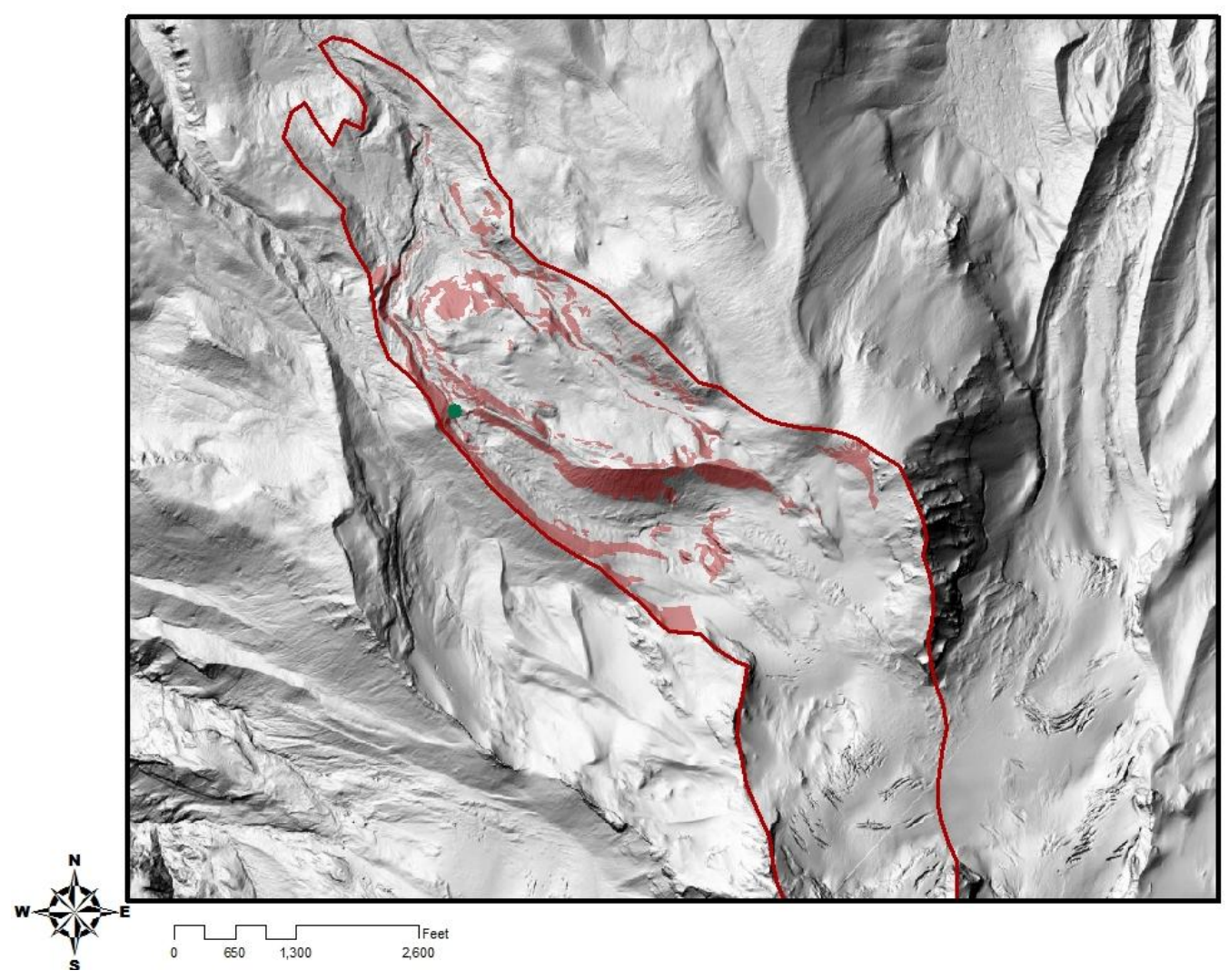

Figure 93. Ladd Creek steep slopes (11.3\%) 
APPENDIX H: $\quad$ ZIGZAG RIVER DRAINAGE BASIN

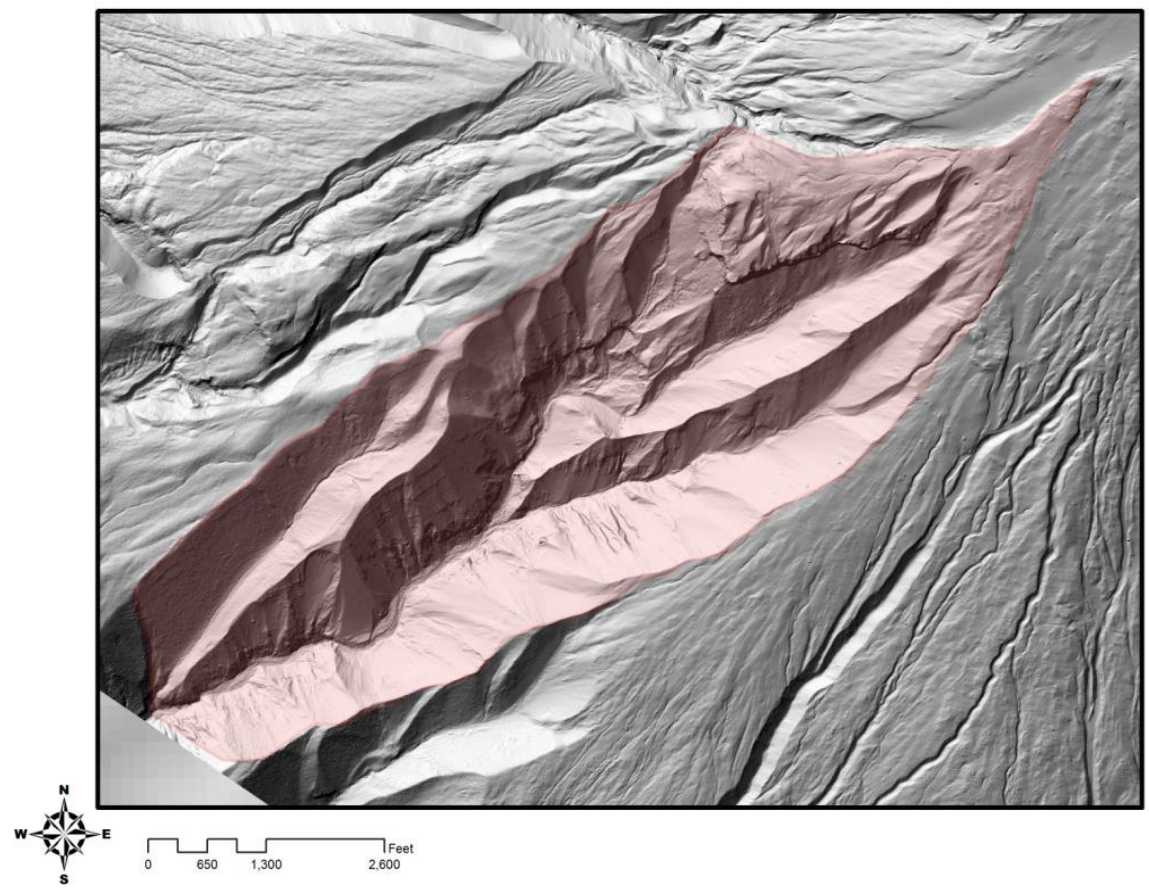

Figure 94. Zigzag River upper drainage basin $\left(3,057,803 \mathrm{~m}^{2}\right)$

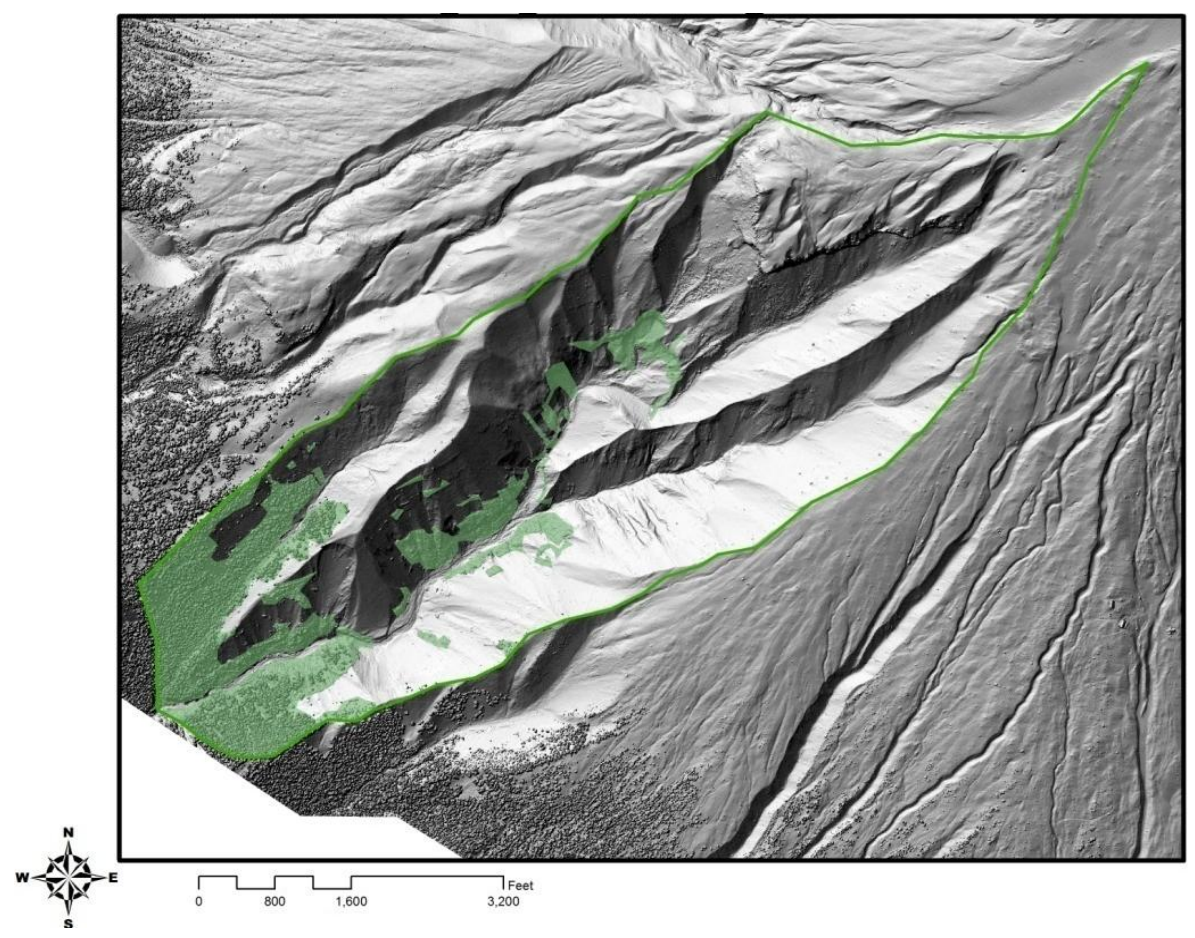

Figure 95. Zigzag River vegetation (16.1\%) 


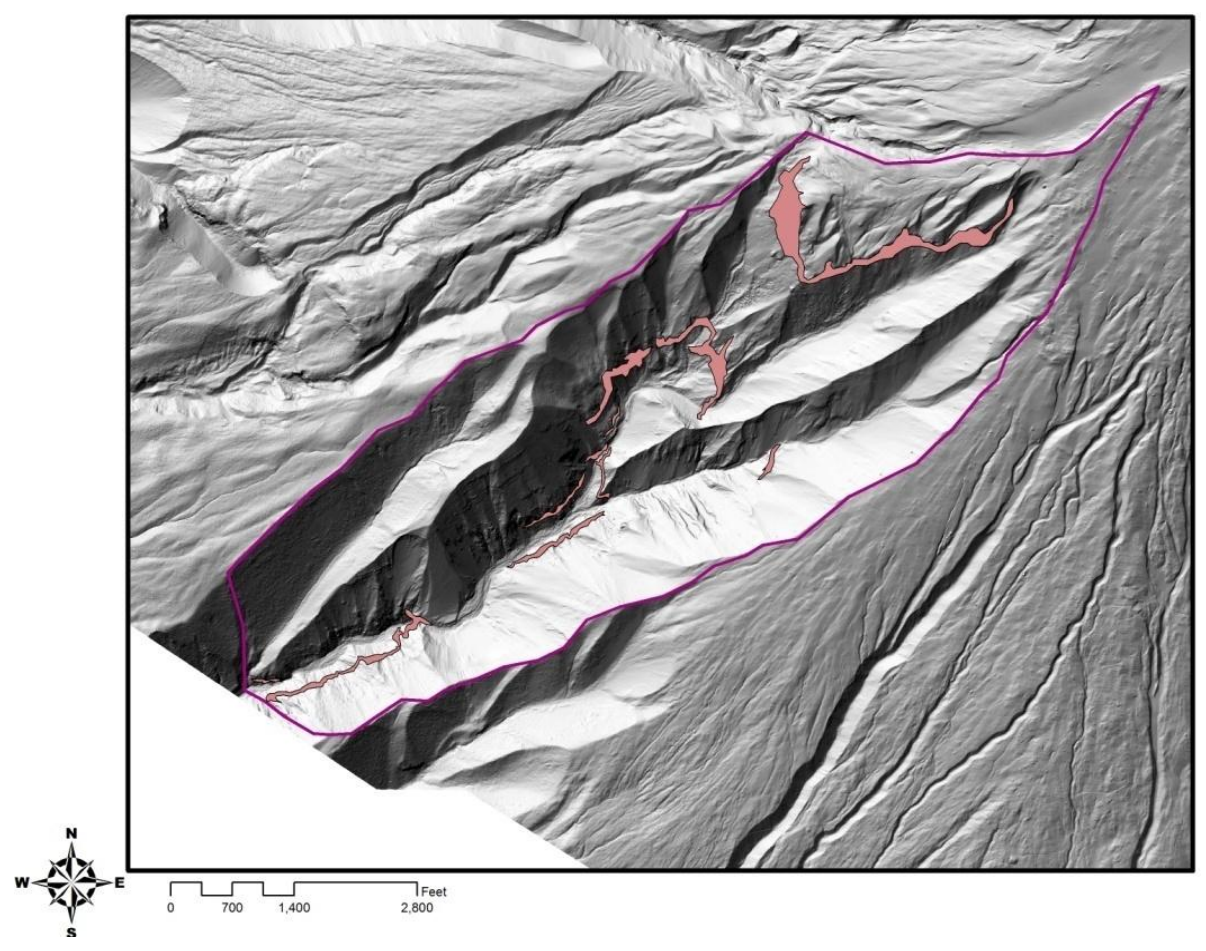

Figure 96. Zigzag River bedrock (3.4\%)

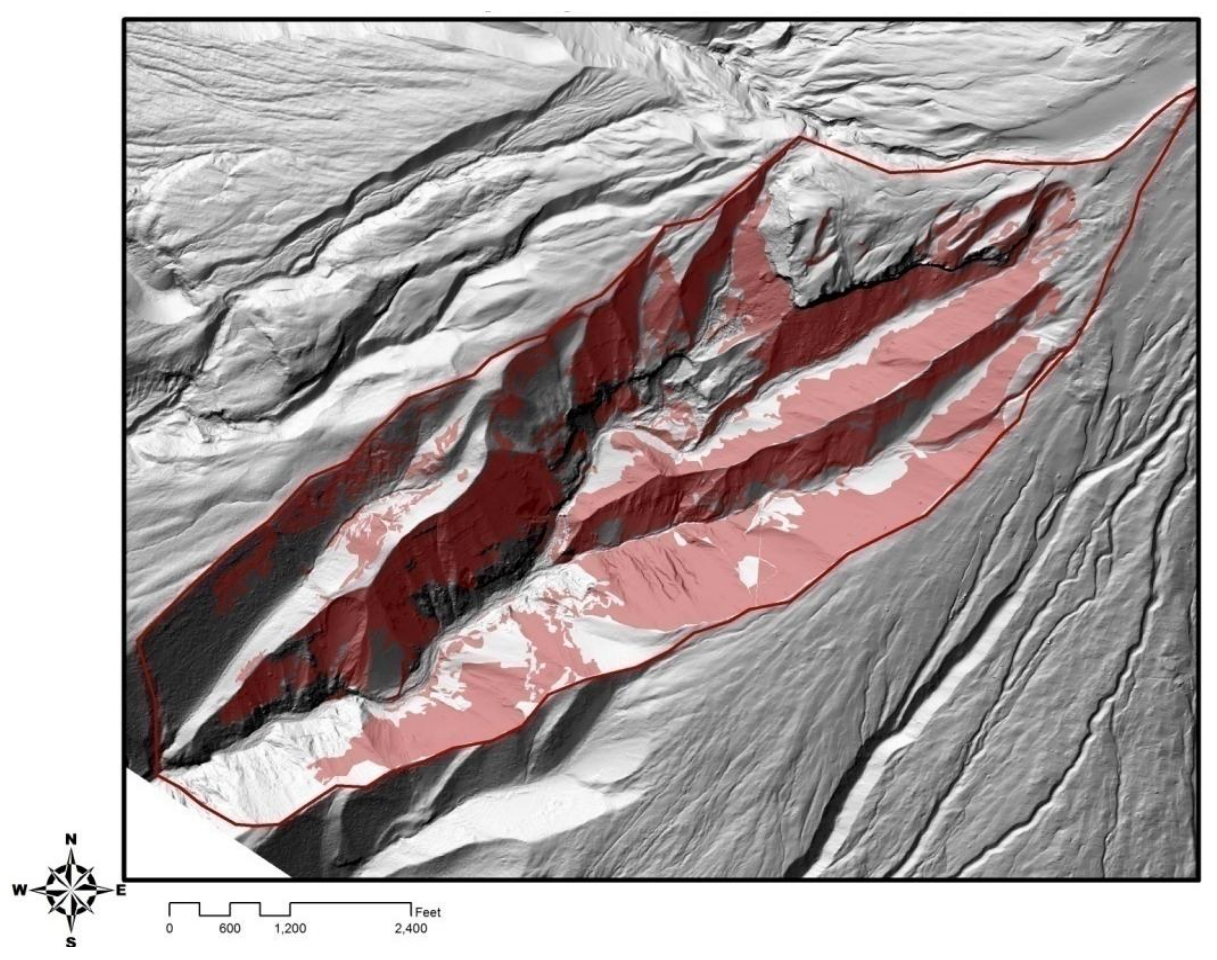

Figure 97. Zigzag River steep slopes (46.3\%) 
APPENDIX I: $\quad$ POLALLIE CREEK DRAINAGE BASIN

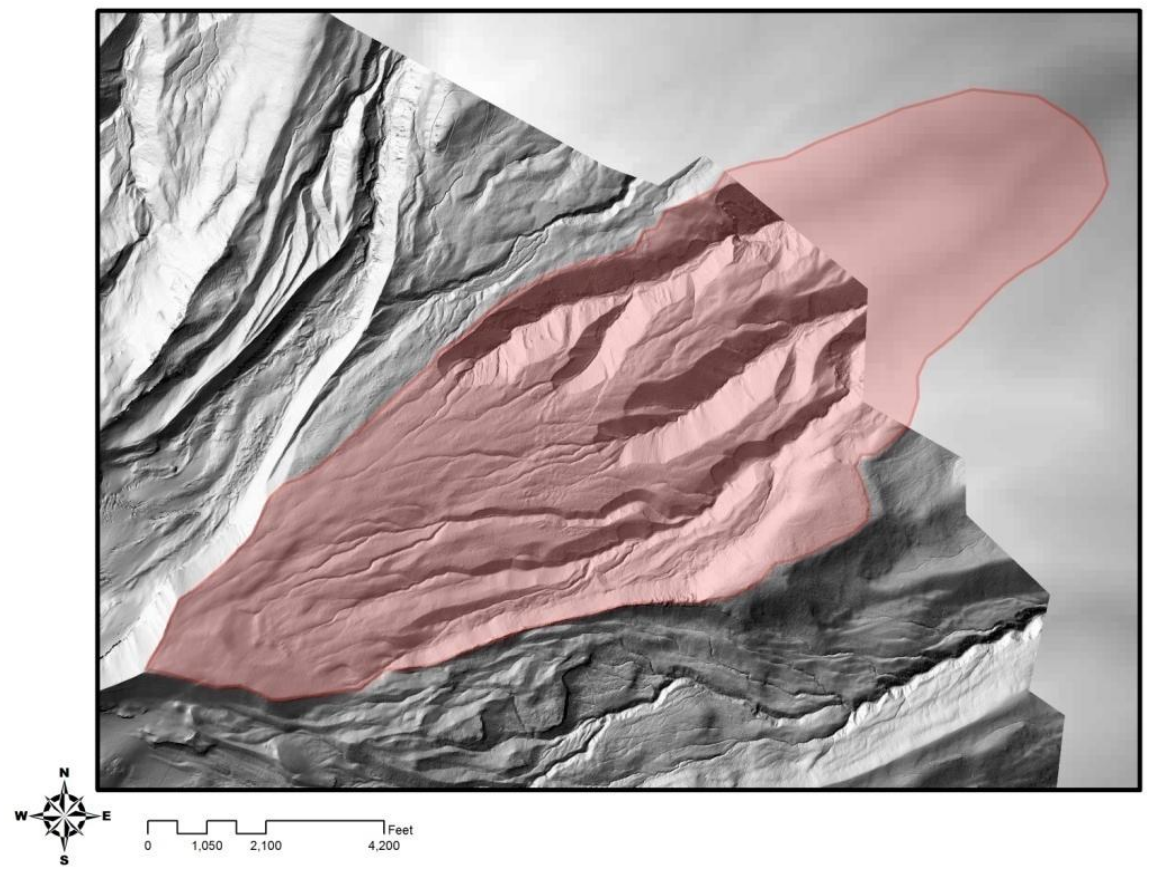

Figure 98. Polallie Creek upper drainage basin $\left(7,887,994 \mathrm{~m}^{2}\right)$

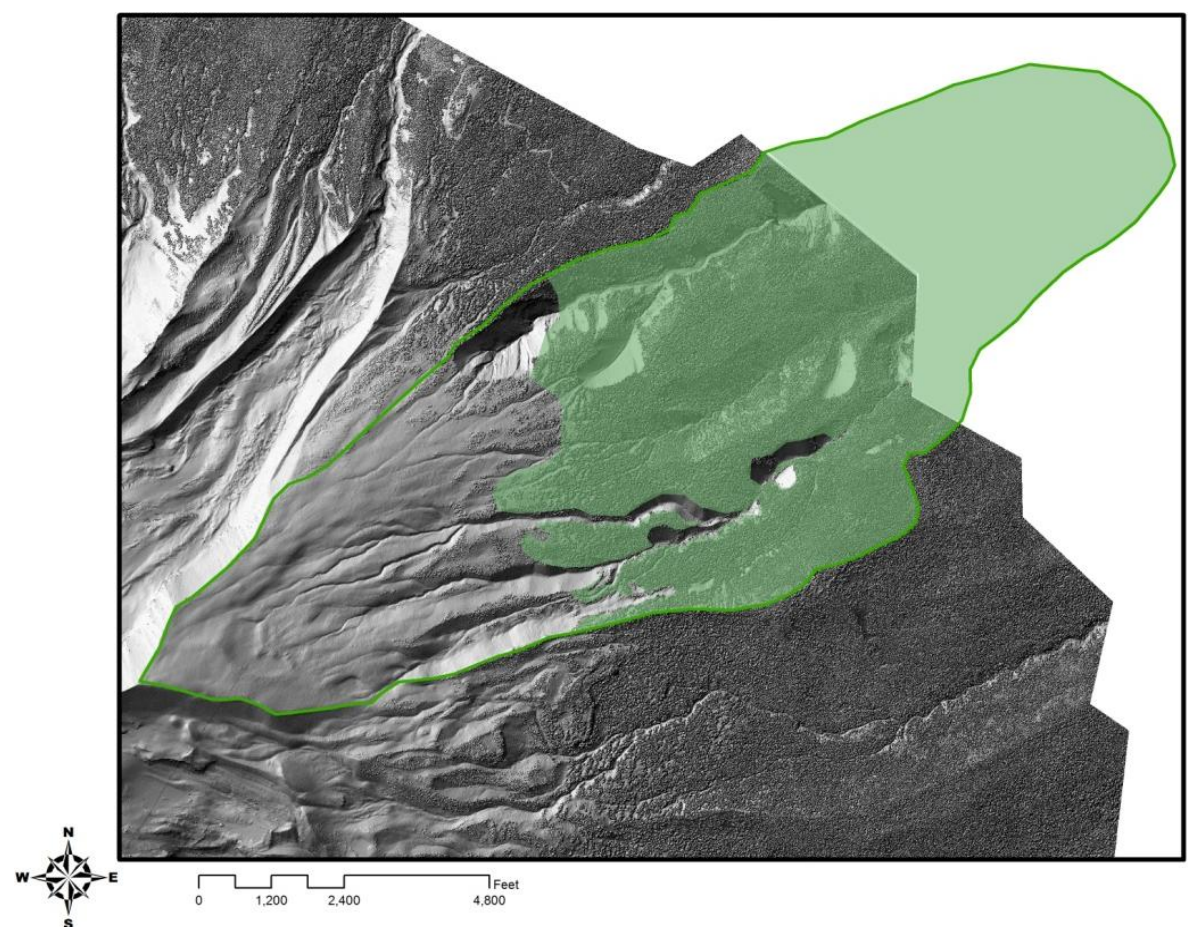

Figure 99. Polallie Creek vegetation (65.9\%) 


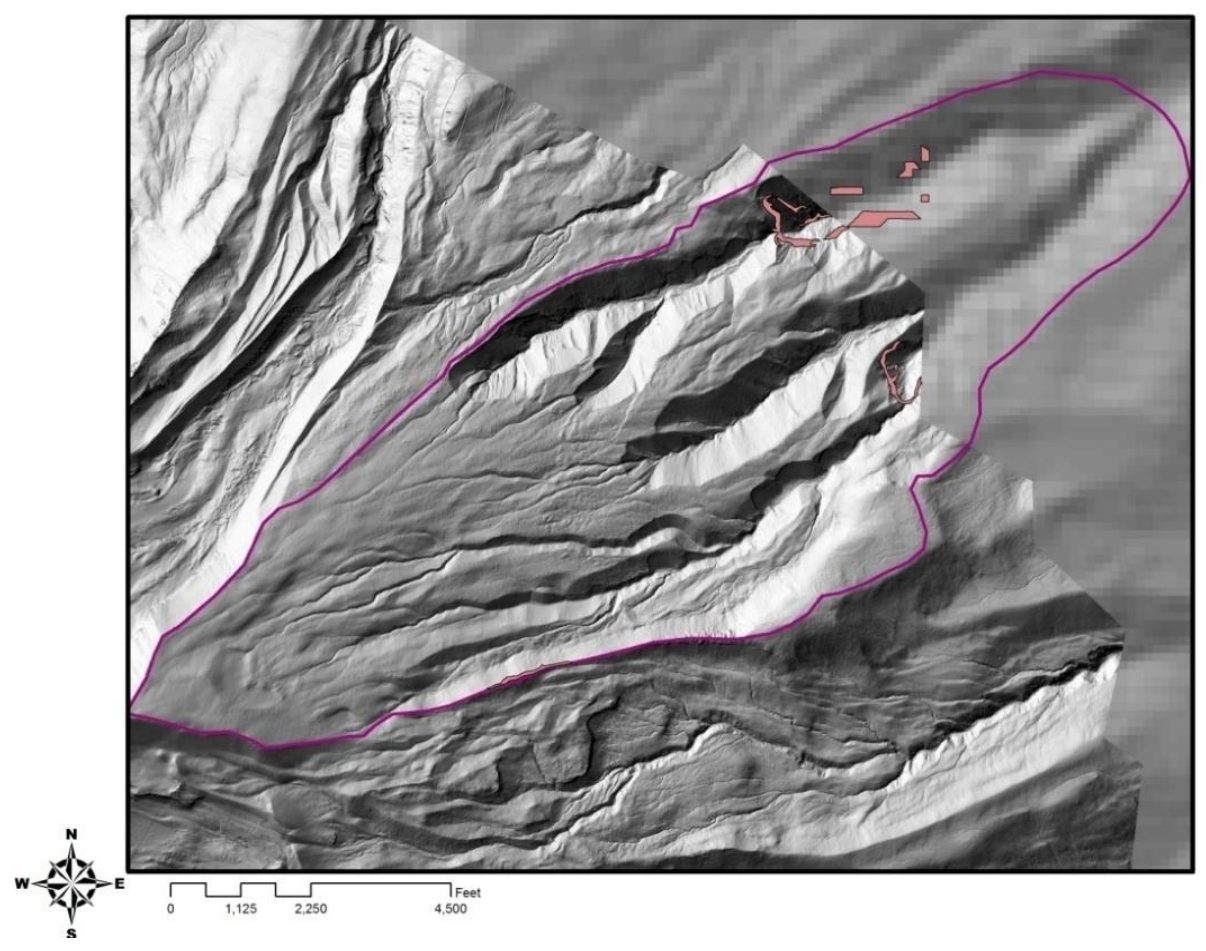

Figure 100. Polallie Creek bedrock (0.9\%)

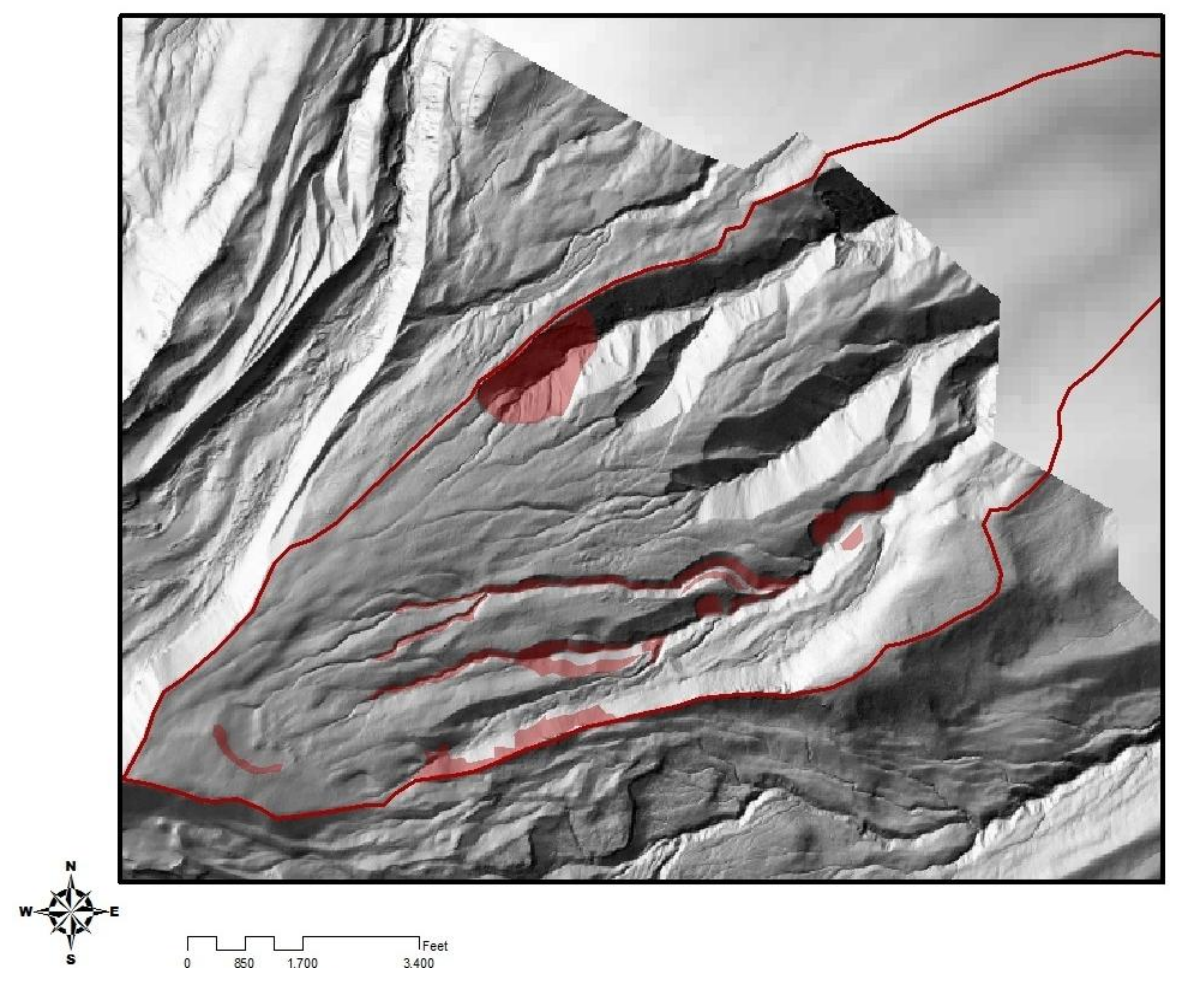

Figure 101. Polallie Creek steep slopes (5.7\%) 
APPENDIX J: $\quad$ COE CREEK DRAINAGE BASIN

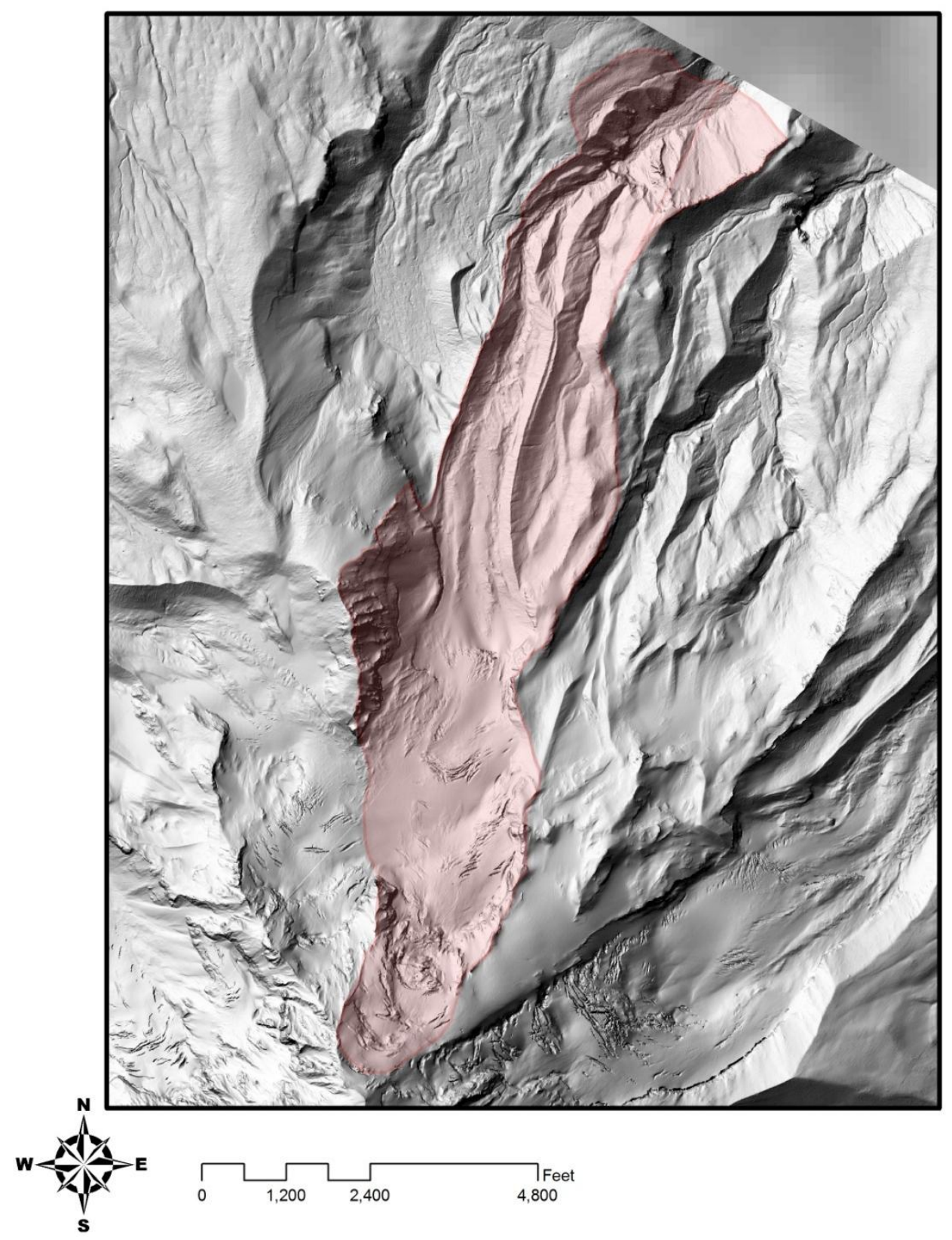

Figure 102. Coe Creek upper drainage basin $\left(3,035,068 \mathrm{~m}^{2}\right)$ 


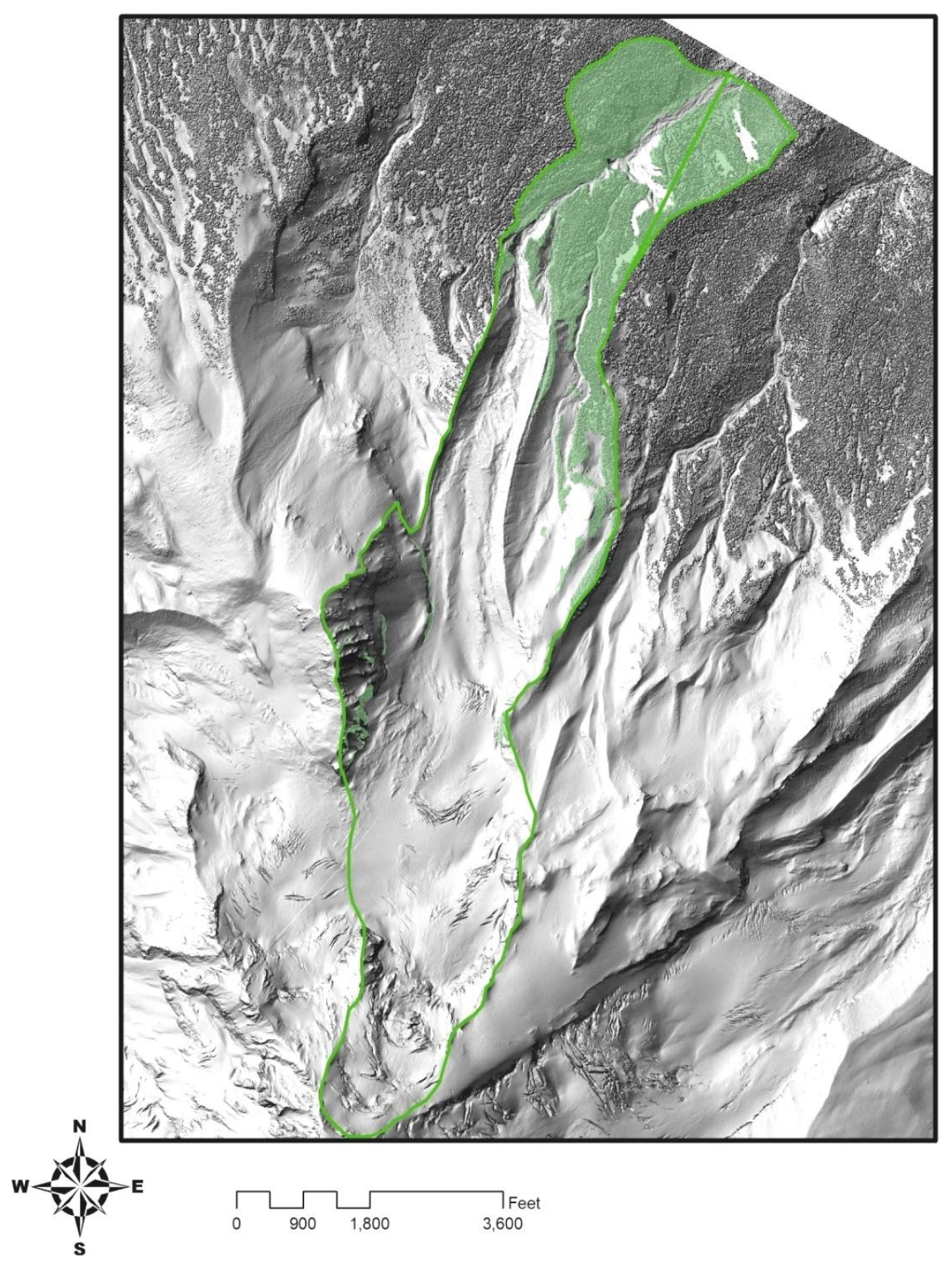

Figure 103. Coe Creek vegetation (25.2\%) 


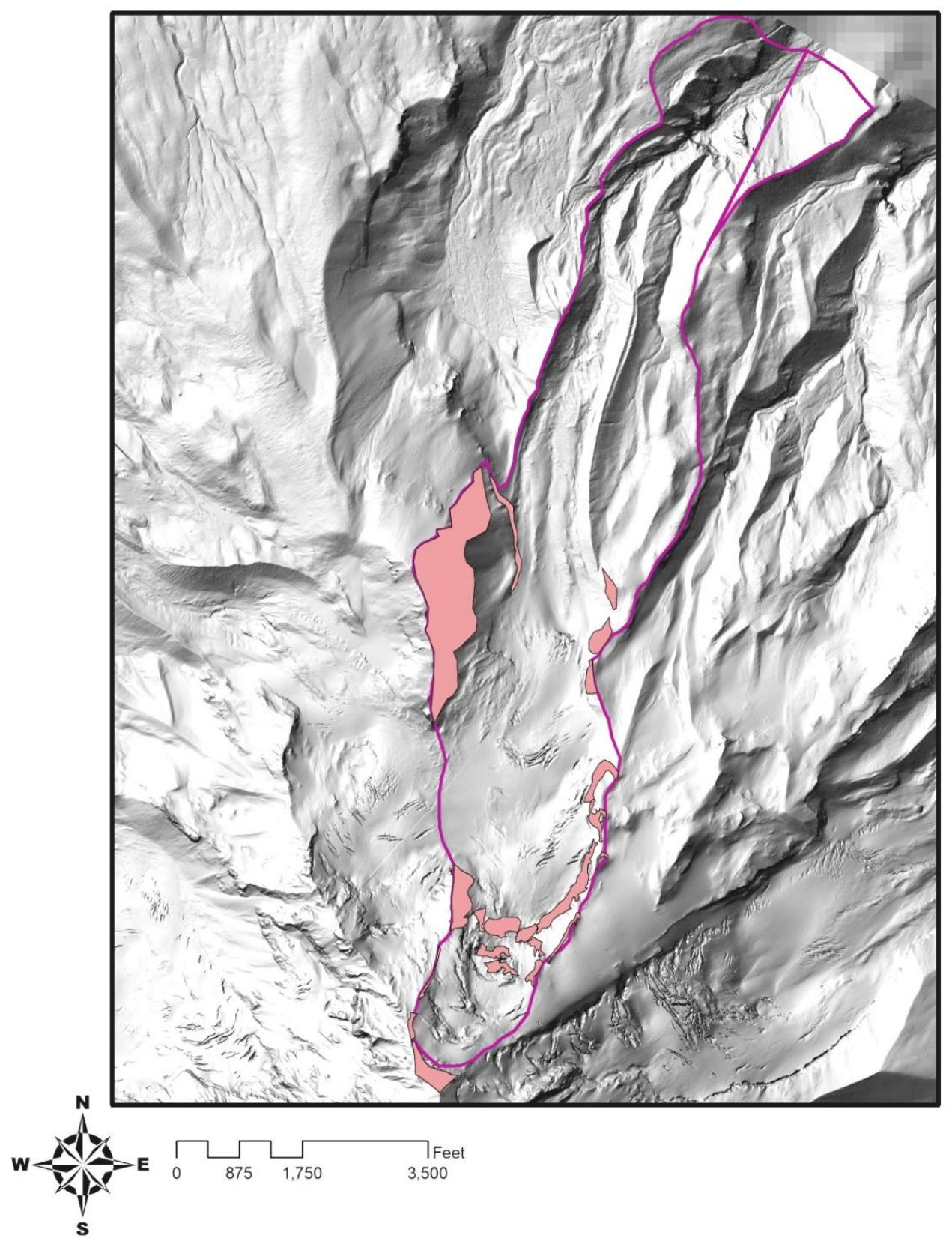

Figure 104. Coe Creek bedrock (9.2\%) 


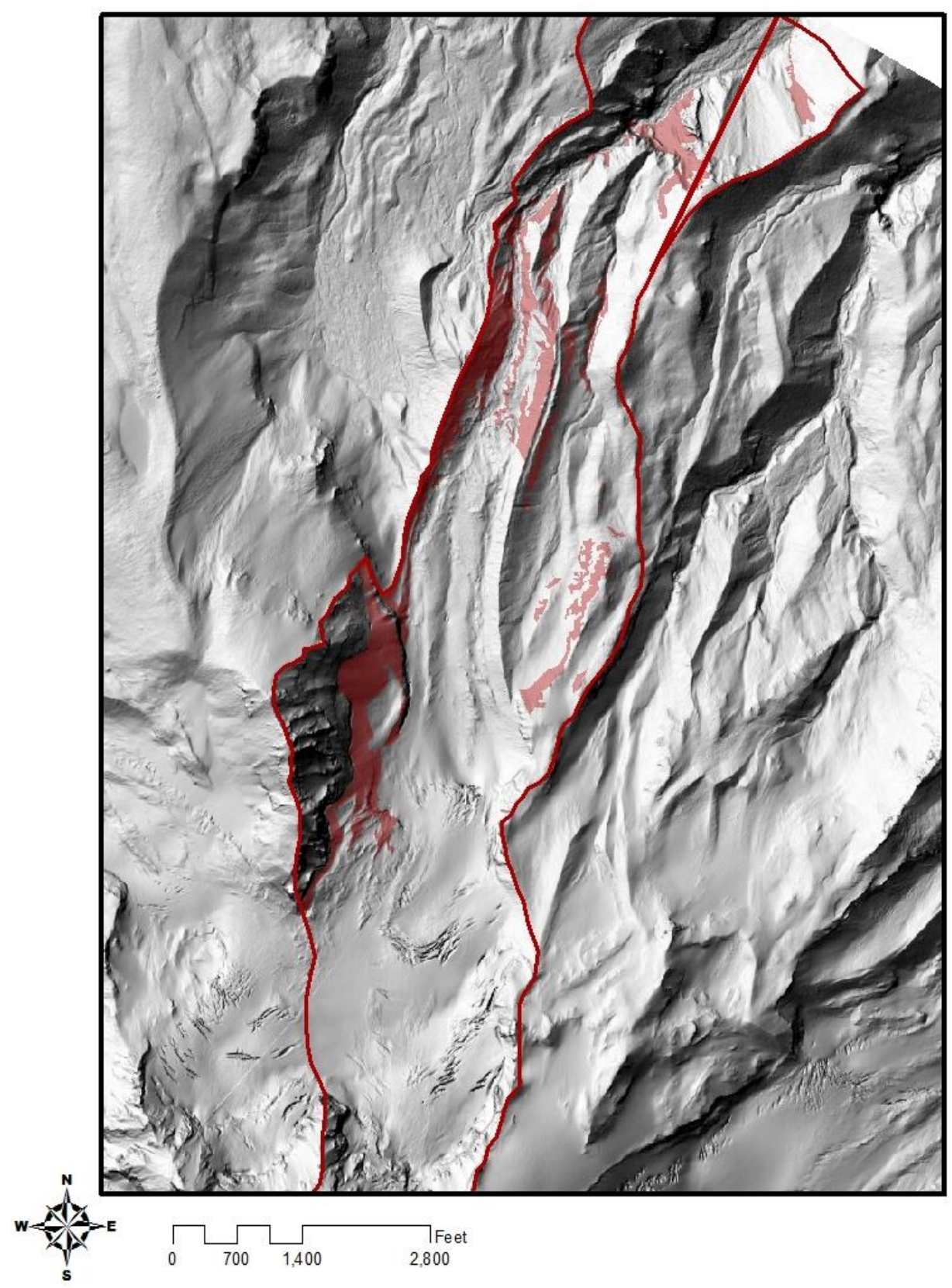

Figure 105. Coe Creek steep slopes (9.9\%) 
APPENDIX K: $\quad$ MUDDY FORK DRAINAGE BASIN

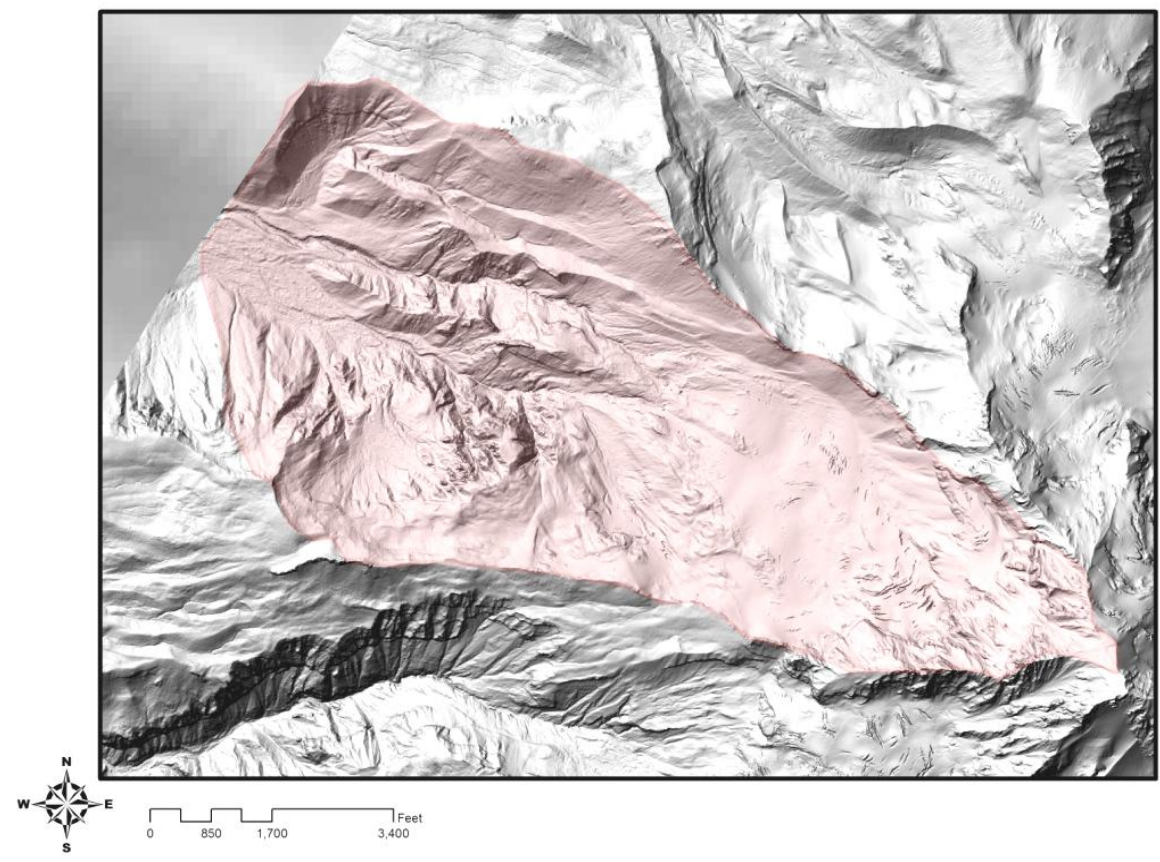

Figure 106. Muddy Fork upper drainage basin $\left(5,397,823 \mathrm{~m}^{2}\right)$

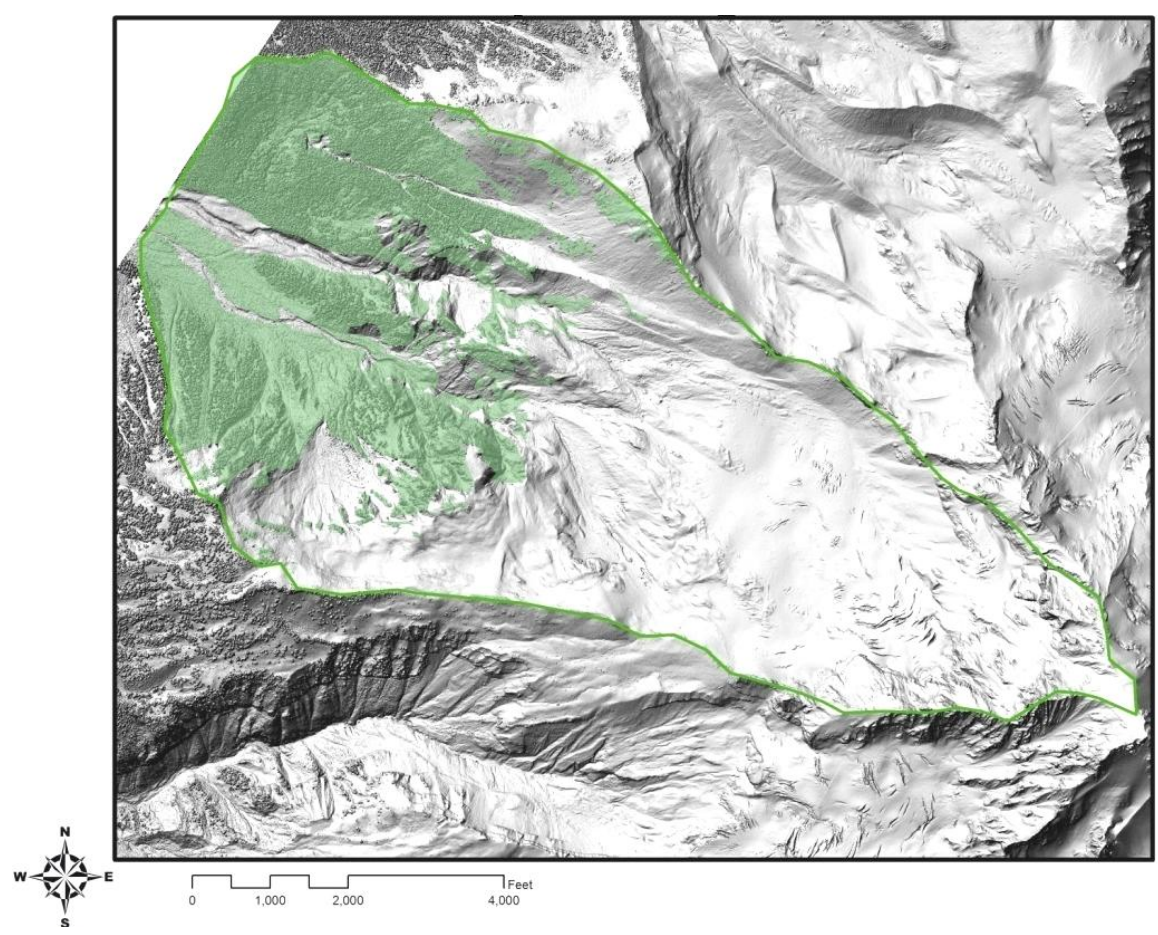

Figure 107. Muddy Fork vegetation (32.4\%) 


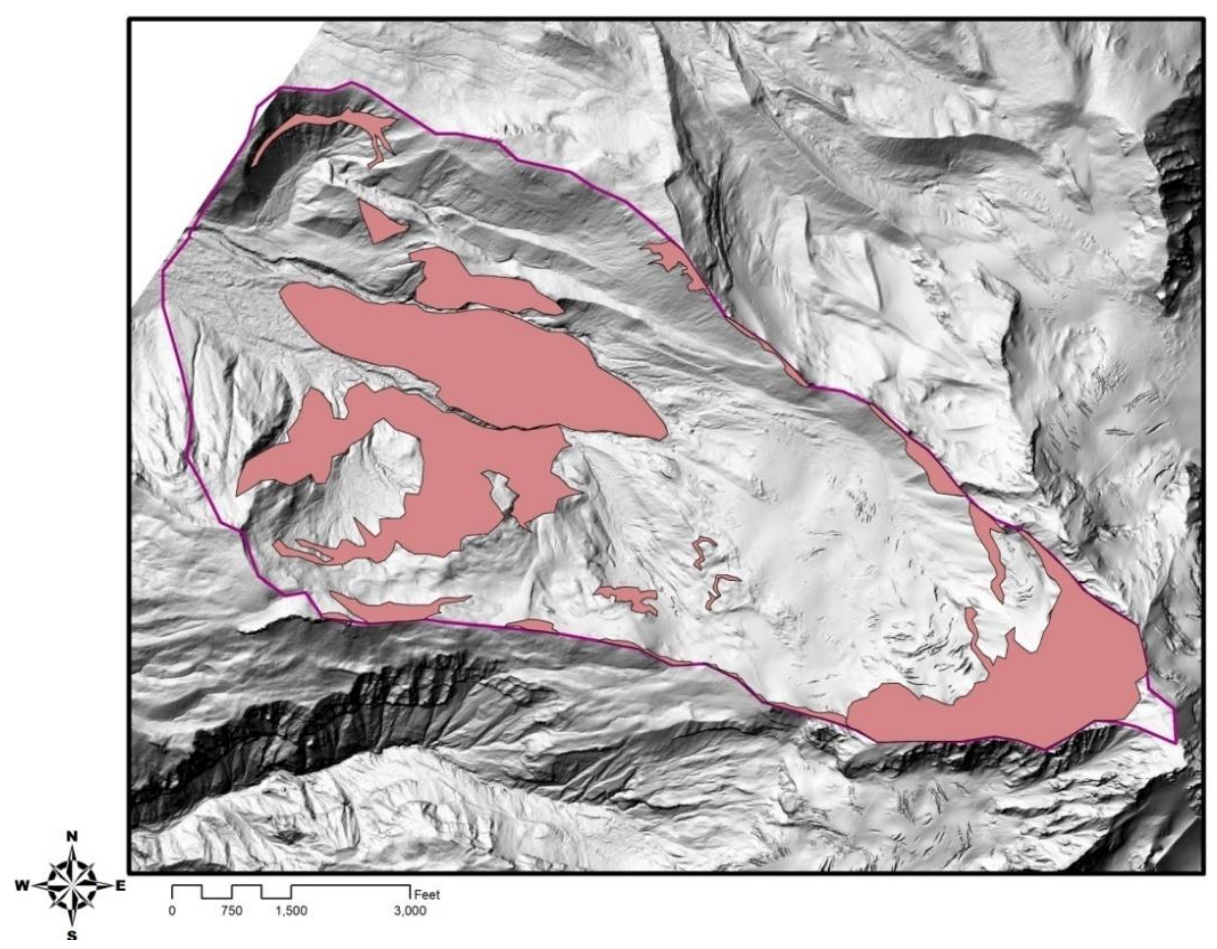

Figure 108. Muddy Fork bedrock (27.0\%)

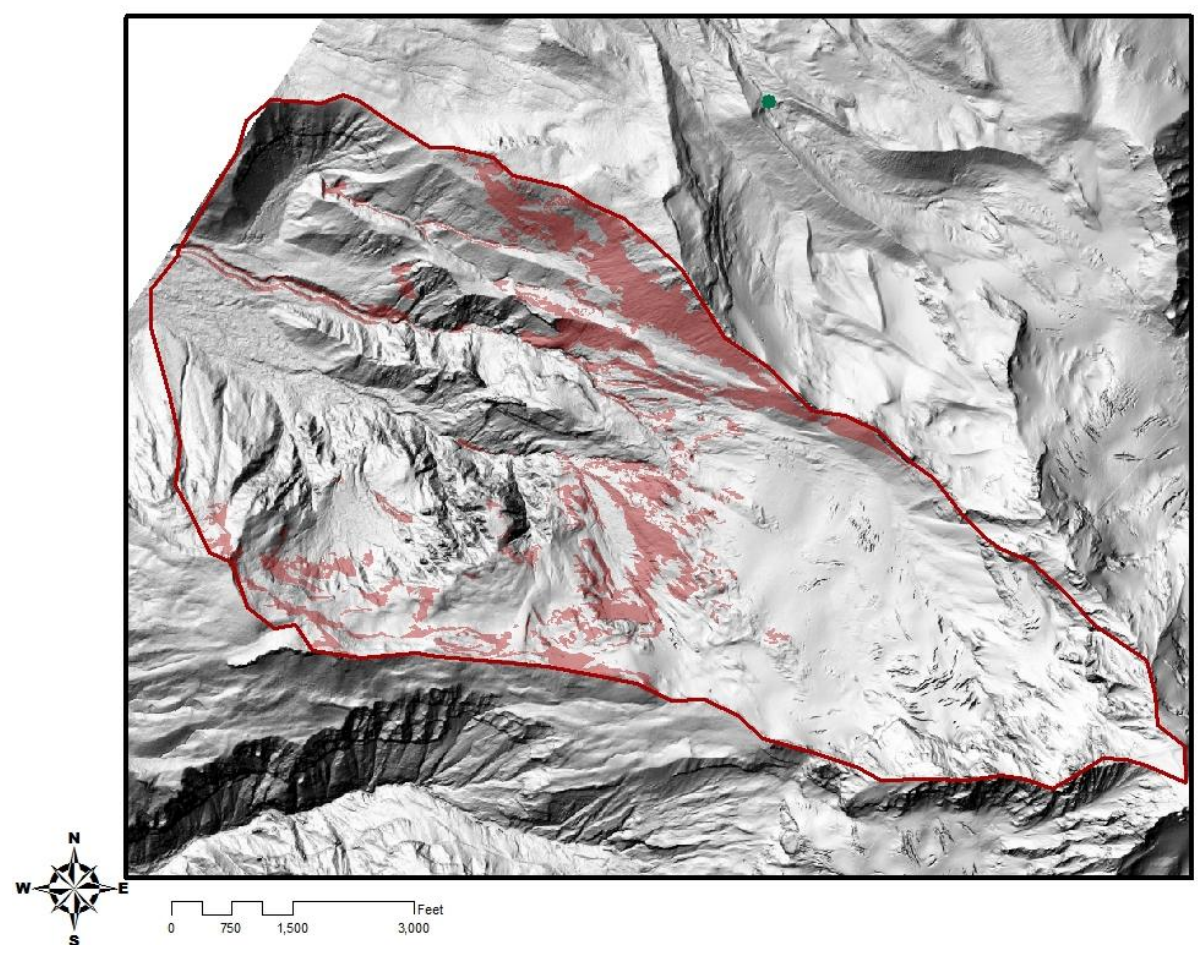

Figure 109. Muddy Fork steep slopes (12.0\%) 
APPENDIX L: $\quad$ NEXRAD DATA

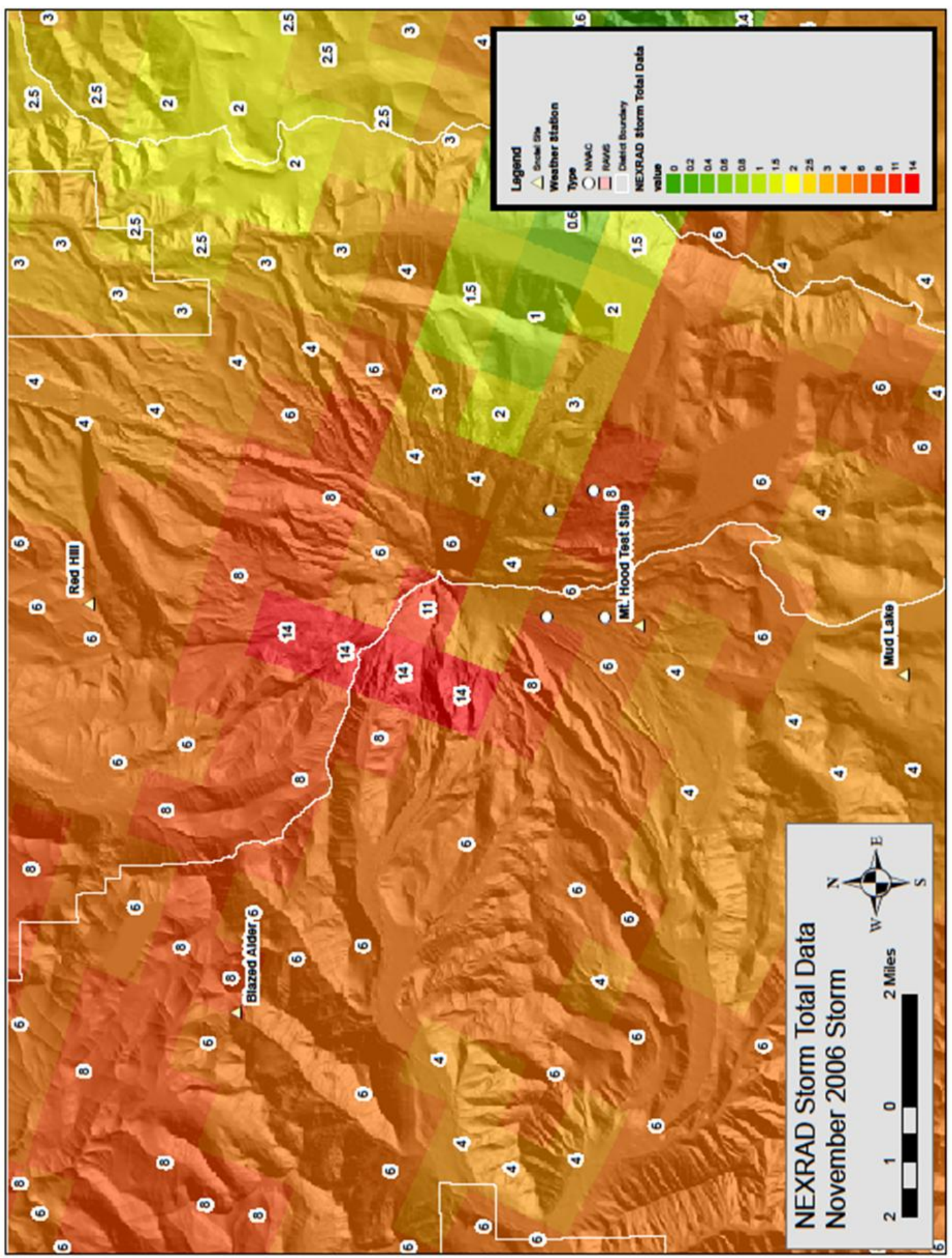




\section{APPENDIX M: $\quad$ RAW DATA FOR BASIN SCALE FACTORS}

Table 21. Raw data for basin scale factors

\begin{tabular}{|l|ccccc|}
\hline Drainage & Y & X1 & X2 & X3 & X4 \\
White & 1 & 7 & 3 & 2 & 42 \\
Clark & 1 & 6 & 8 & 27 & 27 \\
Newton & 1 & 6 & 7 & 24 & 23 \\
Polallie & 0 & 7 & 1 & 66 & 6 \\
Eliot & 1 & 8 & 3 & 4 & 18 \\
Coe & 0 & 8 & 9 & 25 & 10 \\
Ladd & 1 & 14 & 12 & 14 & 11 \\
Muddy & 0 & 14 & 27 & 32 & 12 \\
Sandy & 1 & 14 & 5 & 8 & 30 \\
Zigzag & 0 & 8 & 3 & 16 & 46 \\
Salmon & 1 & 6 & 0 & 4 & 9 \\
\hline
\end{tabular}

\begin{tabular}{|l|ccccc|}
\hline Drainage & $\mathbf{Y}$ & $\mathbf{X 5}$ & $\mathbf{X 6}$ & $\mathbf{X 7}$ & $\mathbf{X 8}$ \\
White & 1 & 18 & 100 & 407,418 & 75 \\
Clark & 1 & 16 & 100 & $1,393,194$ & 68 \\
Newton & 1 & 15 & 100 & $1,393,194$ & 72 \\
Polallie & 0 & 17 & 0 & 0 & 46 \\
Eliot & 1 & 23 & 100 & $1,638,183$ & 85 \\
Coe & 0 & 25 & 100 & $1,244,901$ & 53 \\
Ladd & 1 & 19 & 100 & 669,113 & 33 \\
Muddy & 0 & 30 & 100 & $1,193,823$ & 70 \\
Sandy & 1 & 27 & 100 & 768,903 & 44 \\
Zigzag & 0 & 25 & 0 & 0 & 40 \\
Salmon & 1 & 23 & 100 & 106,209 & 43 \\
\hline
\end{tabular}




\section{APPENDIX N: NORMALIZED DATA FOR BASIN SCALE FACTORS}

Table 22. Normalized data for basin scale factors

\begin{tabular}{|l|rrrrr|}
\hline Drainage & $\mathbf{Y}$ & $\mathbf{X 1}$ & $\mathbf{X 2}$ & $\mathbf{X 3}$ & $\mathbf{X 4}$ \\
White & 0.72075 & -0.56815 & -0.54333 & -0.98872 & 1.517278 \\
Clark & 0.72075 & -0.86575 & 0.12074 & 0.37077 & 0.419248 \\
Newton & 0.72075 & -0.86575 & -0.01207 & 0.207631 & 0.12644 \\
Polallie & -1.26131 & -0.56815 & -0.80896 & 2.491577 & -1.11799 \\
Eliot & 0.72075 & -0.27055 & -0.54333 & -0.87996 & -0.23957 \\
Coe & -1.26131 & -0.27055 & 0.253554 & 0.262011 & -0.82519 \\
Ladd & 0.72075 & 1.515064 & 0.651995 & -0.33617 & -0.75198 \\
Muddy & -1.26131 & 1.515064 & 2.644203 & 0.642669 & -0.67878 \\
Sandy & 0.72075 & 1.515064 & -0.2777 & -0.66244 & 0.638854 \\
Zigzag & -1.26131 & -0.27055 & -0.54333 & -0.22741 & 1.810086 \\
Salmon & 0.72075 & -0.86575 & -0.94177 & -0.87996 & -0.89839 \\
\hline
\end{tabular}

\begin{tabular}{|l|rrrrr|}
\hline Drainage & $\mathbf{Y}$ & $\mathbf{X 5}$ & $\mathbf{X 6}$ & $\mathbf{X 7}$ & \multicolumn{1}{|c|}{$\mathbf{\text { 8 }}$} \\
White & 0.72075 & -0.73836 & 0.449467 & -0.64826 & 1.030515 \\
Clark & 0.72075 & -1.14446 & 0.449467 & 0.973909 & 0.62567 \\
Newton & 0.72075 & -1.34751 & 0.449467 & 0.973909 & 0.85701 \\
Polallie & -1.26131 & -0.94141 & -2.0226 & -1.31869 & -0.6467 \\
Eliot & 0.72075 & 0.276887 & 0.449467 & 1.377056 & 1.608865 \\
Coe & -1.26131 & 0.682987 & 0.449467 & 0.729882 & -0.24186 \\
Ladd & 0.72075 & -0.53531 & 0.449467 & -0.21762 & -1.39856 \\
Muddy & -1.26131 & 1.698238 & 0.449467 & 0.64583 & 0.74134 \\
Sandy & 0.72075 & 1.089087 & 0.449467 & -0.05341 & -0.76237 \\
Zigzag & -1.26131 & 0.682987 & -2.0226 & -1.31869 & -0.99371 \\
Salmon & 0.72075 & 0.276887 & 0.449467 & -1.14392 & -0.82021 \\
\hline
\end{tabular}

